*ak RMIS View/Frint Document Cover Sheet tow

This document was retrieved from the Documentation and Records Manaqement (DRM) ISEARCH System. It is intended for Information only and may not be the most recent or updated version. Contact a Document Service Center (see Hanford Info for locations) if you need additional retrieval information.

Accession \#: D196017886

Document \#: SD-WM-ES-370

Title/Desc:

PHASE I HLW PRETREATMENT \& FEED STAGING PLAN

Pages: 170 


\begin{tabular}{|l|l|l|}
\hline $\begin{array}{l}\text { 2. To: (Receiving Organization) } \\
\text { Tank Farm Transition } \\
\text { Projects }\end{array}$ & $\begin{array}{l}\text { 3. From: (Originating Organization) } \\
\text { TWRS Disposal Engineering }\end{array}$ \\
\hline $\begin{array}{l}\text { 5. Proj./Prog./Dept./Div.: } \\
\text { TWRS Disposal Program }\end{array}$ & $\begin{array}{l}\text { 6. Cog. Engr.: } \\
\text { A. F. Manuel } 376-2279\end{array}$ 74A20 \\
\hline
\end{tabular}

8. Originator Renarks:
Ior Raluew and leppurat

4. Related EDT No.:

$$
\text { NiA }
$$

7. Purchase Order No.:

$$
\text { Nift }
$$

9. Equip./Component No.:

$$
\text { Nith }
$$

10. System/Bldg./Facility: $\Lambda^{\prime} / A$

11. Receiver Remarks:

12. Major Assm. Owg. No.: $n^{\prime} / 4$

13. Permit/Permit Application No.:

$$
12 / A
$$

14. Required Response Date: A'ip

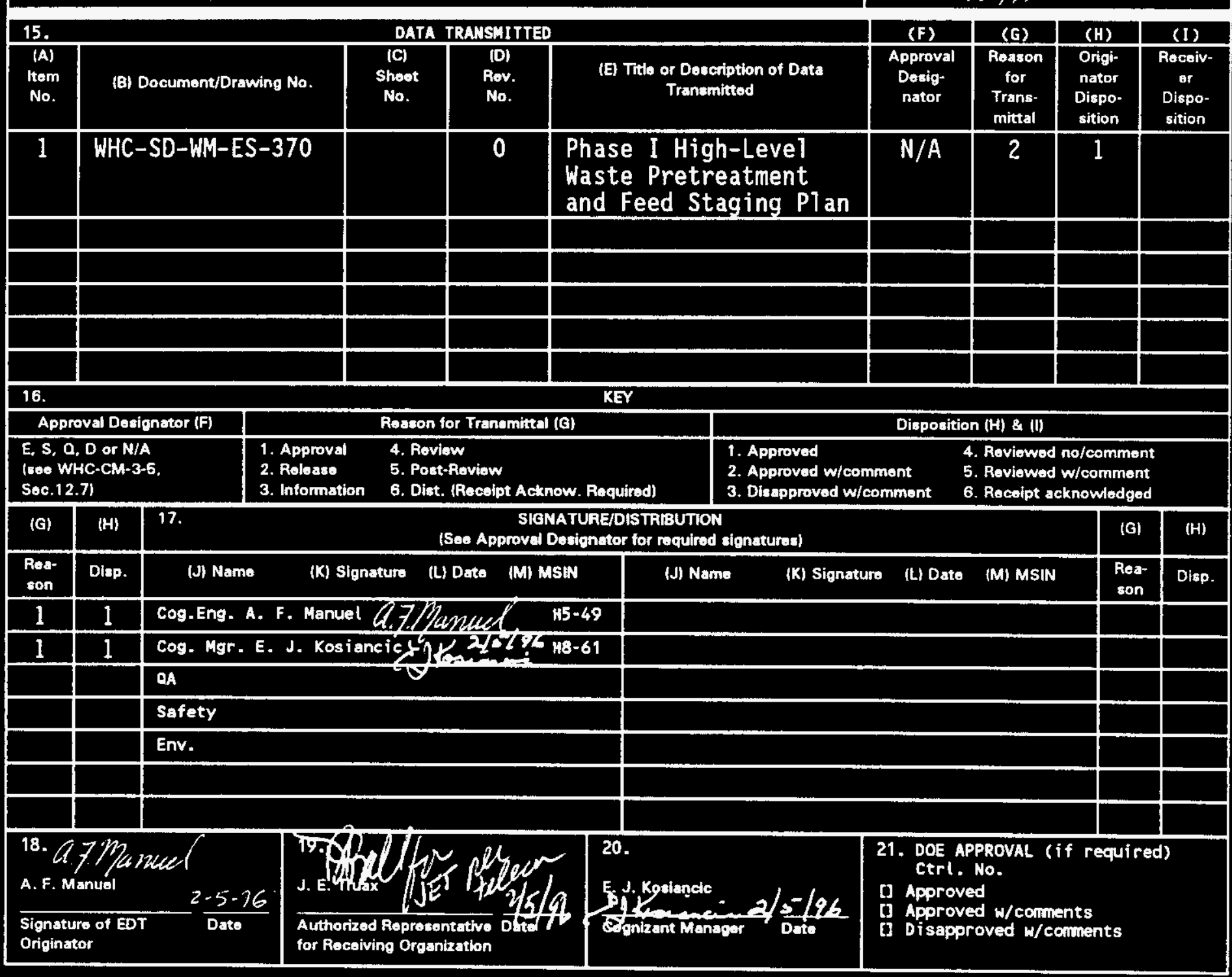




\section{Phase I High-Level Waste Pretreatment and Feed Staging Plan}

A. F. Manuel, J. D. Galbraith, S. L. Lambert, and G. E. Stegen

Westinghouse Hanford Company, Richland, WA 99352

U.S. Department of Energy Contract DE-AC06-87RL10930

$\begin{array}{llll}\text { EDT/ECN: } & 608991 & \text { UC: } 630 & \\ \text { Org Code: } & 74 A 20 & \text { Charge Code: } & 05124 \\ \text { B\&R Code: } & & \text { Total Pages: } 168\end{array}$

Key Words: RFP, high-heat, high-level waste, pretreatment, feed staging

Abstract: This document provides the preliminary planning bas is for the U.S. Department of Energy (DOE) to provide a sufficient quantity of high-level waste feed to the privatization contractor during Phase $I$. By this analys is of candidate high-level waste feed sources, the initial quantity of high-level waste feed totals more than twice the minimum feed requirements. The flexibility of the current infrastructure within tank farms provides a variety of methods to transfer the feed to the privatization contractor's site location. The amount and type of pretreatment (sludge washing) necessary for the Phase I processing can be tailored to support the demonstration goals without having a significant impact on glass volume (i.e., either inhibited water or caustic leaching can be used).

TRADEMARK DISCLAIMER. Reference herein to any specific comercial product, process, or service by trade name, trademark, manufacturer, or otheruise, does not necessarily constitute or inply its endorsement, recommendation, or favoring by the United states Governient or any agency thereof or its contractors or subcontractors.

Printed in the United States of America. To obtain copies of this document, contact: WHC/BCS Document Control Services, P.0. Box 1970, Mailstop H6-08, Richland WA 99352, Phone (509) 372-2420; Fax (509) 376-4989.
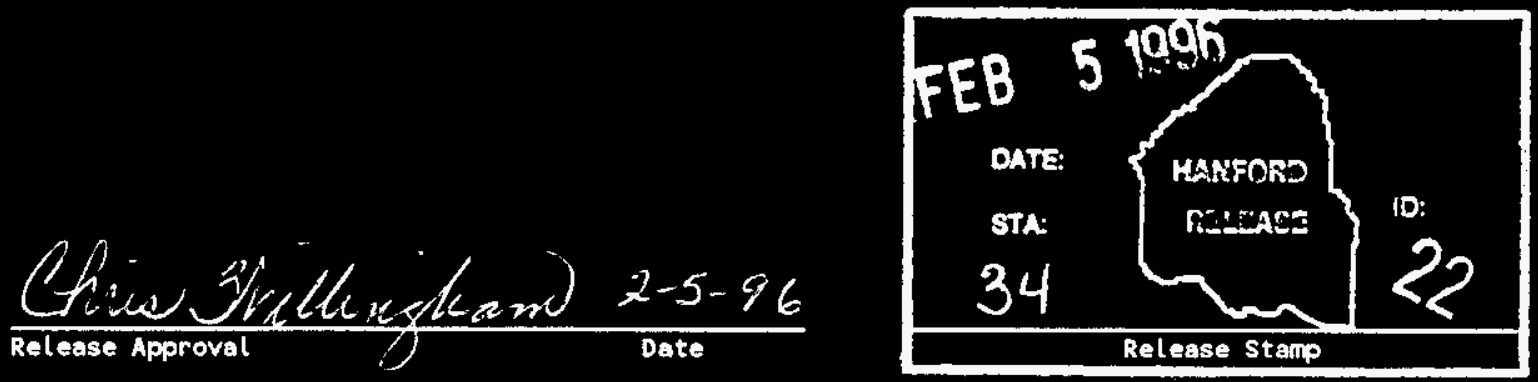

Approved for Public Release 


\title{
PHASE I \\ HIGH-LEVEL WASTE \\ PRETREATMENT AND \\ FEED STAGING PLAN
}

February 1996

\author{
A. F. Manuel \\ J. D. Galbraith \\ S. L. Lambert \\ G. E. Stegen
}

Prepared by:

Westinghouse Hanford Company

Richland, Washington

Prepared for:

U.S. Department of Energy

Richland, Washington 
WHC-SD-WM-ES-370

Revision 0

This page intentionally left blank. 
WHC-SD-WM-ES-370

Revision 0

CONTENTS

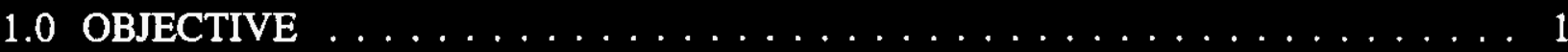

1.1 BACKGROUND AND SCOPE $\ldots \ldots \ldots \ldots \ldots \ldots \ldots \ldots \ldots \ldots$

1.2 PURPOSE AND NEED $\ldots \ldots \ldots \ldots \ldots \ldots \ldots \ldots \ldots$

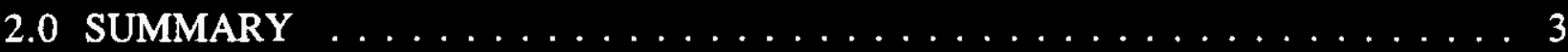

3.0 ASSUMPTIONS AND METHODS OF ANALYSIS $\ldots \ldots \ldots \ldots \ldots \ldots \ldots$

3.1 TANK WASTE INVENTORY $\ldots \ldots \ldots \ldots \ldots \ldots \ldots \ldots$

3.2 PROCESS PARAMETERS FOR WASTE CONSOLIDATION $\ldots \ldots \ldots .8$

3.2.1 Consolidation of High-Heat Sludge and Aging Waste $\ldots \ldots \ldots 8$

3.2.2 Phase I High-Level Waste Pretreatment $\ldots \ldots \ldots \ldots \ldots \ldots$

3.2.3 High-Level Waste Product Criteria . . . . . . . . . . . . 13

3.2.4 Alternative High-Level Waste Glass Formulations . . . . . . . . 14

3.2.5 Thermodynamic Modeling Results . . . . . . . . . . . . . 15

3.3 PHASE I TRANSFER OF CONSOLIDATED HIGH-LEVEL WASTE

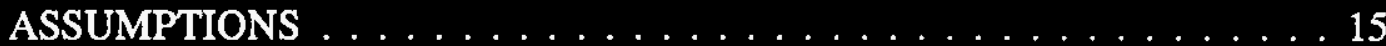

3.4 TANK SAFETY ISSUES $\ldots \ldots \ldots \ldots \ldots \ldots \ldots \ldots$

4.0 PHASE I HIGH-LEVEL WASTE PRETREATMENT STRATEGY . . . . . . . . 17

4.1 CONSOLIDATION OF HIGH-HEAT SLUDGE AND AGING WASTE . . . 17

4.1.1 Consolidated Sludge Volumes . . . . . . . . . . . . . . . 17

4.1.2 Sludge Transfer Volumes . . . . . . . . . . . . . . . . . . 19

4.2 MINIMUM QUANTITY OF PRETREATED FEED FOR PHASE I

HIGH-LEVEL WASTE VITRIFICATION . . . . . . . . . . . 20

4.3 PHASE I HIGH-LEVEL WASTE FEED ENVELOPE ASSESSMENT . . . . 21

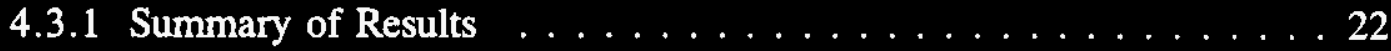

4.3.2 Recommendations and Conclusions . . . . . . . . . . 24

4.4 IMPACT OF ALTERNATIVE PRETREATMENT STRATEGIES ON

HIGH-LEVEL WASTE VOLUMES . . . . . . . . . . . . . . . . 24

4.5 RELATIONSHIPS BETWEEN PRETREATMENT AND THE

HIGH-LEVEL WASTE GLASS FORMULATION . . . . . . . . . 25

4.5.1 Alternative High-Level Waste Glass Formulations . . . . . . . . 26

4.5.2 Alternative Pretreatment Strategies . . . . . . . . . 26

4.6 RECOMMENDATIONS AND CONCLUSIONS $\ldots \ldots \ldots \ldots \ldots$

4.6.1 Neutralized Current Acid Waste Consolidation . . . . . . . 33

4.6.2 High-Level Waste Glass Formulation . . . . . . . . . . . 33

4.6.3 Dilute Caustic Washing Versus Caustic Leaching . . . . . . . . 34

4.6.4 In-Tank Sludge Washing . . . . . . . . . . . . . . . 34

4.6.5 Low-Level Waste Feed Volume Impacts . . . . . . . . . . . 34

5.0 PRELIMINARY FEED STAGING STRATEGY AND ARCHITECTURE $\ldots \ldots$. . 37

5.1 CRITERIA FOR EVALUATION OF HIGH-LEVEL WASTE

TRANSFER ALTERNATTVES . . . . . . . . . . . . . . . 39 


\section{WHC-SD-WM-ES-370 \\ Revision 0}

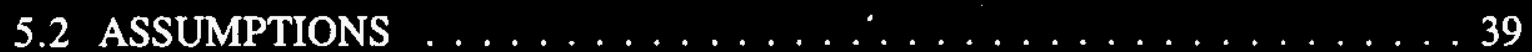

5.3 EXISTING SYSTEM DESCRIPTION $\ldots \ldots \ldots \ldots \ldots \ldots \ldots \ldots$

5.4 OPTIONS FOR THE PHASE I FEED TO THE

HIGH-LEVEL WASTE PROCESS FACILITY $\ldots \ldots \ldots \ldots \ldots \ldots$

5.4.1 Feed from 241-AP Tank Farm . . . . . . . . . . . . . 43

5.4 .2 Feed from Tank $241-$ AZ-102 . . . . . . . . . . . . . . 43

5.5 ALTERNATIVES FOR TRANSFER ROUTES $\ldots \ldots \ldots \ldots \ldots \ldots$

5.5.1 Alternative 1 Transfer Route $\ldots \ldots \ldots \ldots \ldots \ldots \ldots \ldots$

5.5.2 Alternative 2 Transfer Route . . . . . . . . . . . . . . 47

5.5.3 Alternative 3 Transfer Route . . . . . . . . . . . . . 48

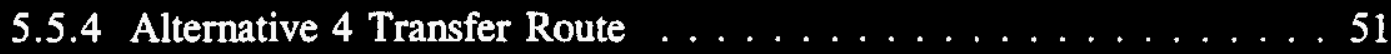

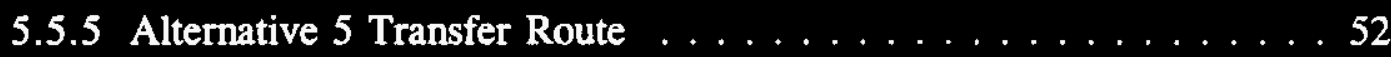

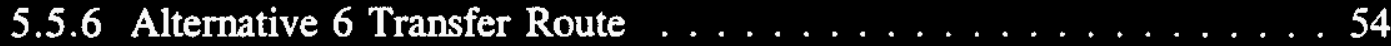

5.5.7 Alternative 7 Transfer Route . . . . . . . . . . . . . 56

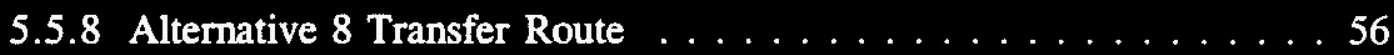

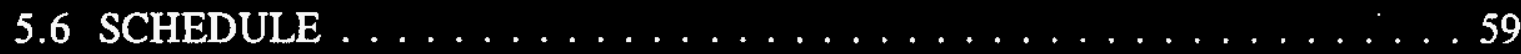

6.0 REFERENCES . . . . . . . . . . . . . . . . . . . 61

\section{APPENDIXES}

A TANK WASTE INVENTORY ASSUMPTIONS AND METHODOLOGY A-1

B PHASE I HIGH-LEVEL WASTE FEED ENVELOPE ASSESSMENT AND RECOMMENDED PHASE I HIGH-LEVEL WASTE FEED

SPECIFICATION INPUT $\ldots \ldots \ldots \ldots \ldots \ldots \ldots$. . . . . . . . .

C ALTERNATIVE HIGH-LEVEL WASTE GLASS FORMULATIONS AND IMPACTS OF SLUDGE WASHING ALTERNATIVES:

DATA SUMMARY TABLES . . . . . . . . . . . . . . . C-1

D PHASE I HIGH-LEVEL WASTE INVENTORY AND GLASS COMPOSITION ESTIMATES $\ldots \ldots \ldots \ldots \ldots \ldots \ldots$. . . . . .

E A FARM COMPLEX WASTE TRANSFER SYSTEM VALVE PIT CONFIGURATIONS . . . . . . . . . . . . . . E-1 
WHC-SD-WM-ES-370

Revision 0

\section{LIST OF FIGURES}

2-1. Proposed Phase I High-Level Waste Feed Transfer System $\ldots \ldots \ldots \ldots$. . . . 5

4-1. Impact of Alternative Phase I High-Level Waste Pretreatment Strategies (Low-Temperature Composition Variation Study

Glass Formulation)--Minimum Retrieval Case. . . . . . . . . . . . . . . . . . . 29

4-2. Impact of Alternative Phase I High-Level Waste Pretreatment Strategies (Low-Temperature Hanford Waste Vitrification Plant

Glass Formulation)--Minimum Retrieval Case. . . . . . . . . . . . . . . 30

4-3. Impact of Alternative Phase I High-Level Waste Pretreatment Strategies (Low-Temperature Composition Variation Study

Glass Formulation)--Maximum Retrieval Case. . . . . . . . . . . . . . 31

4-4. Impact of Alternative Phase I High-Level Waste Pretreatment Strategies (Low-Temperature Hanford Waste Vitrification Plant Glass Formulation)--Maximum Retrieval Case. . . . . . . . . . . . . . . 32

5-1. A Farm Complex. $\ldots \ldots \ldots \ldots \ldots \ldots \ldots \ldots \ldots \ldots \ldots \ldots$

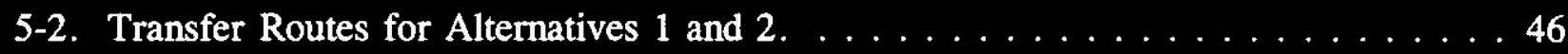

5-3. Transfer Routes for Alternatives 3 and $4 \ldots \ldots \ldots \ldots \ldots$

5-4. Alternative 5 Transfer Route. $\ldots \ldots \ldots \ldots \ldots \ldots \ldots \ldots \ldots \ldots \ldots \ldots$

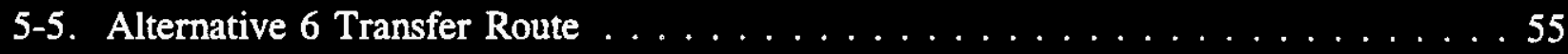

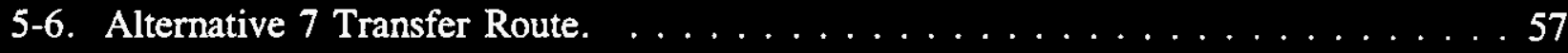

5-7. Alternative 8 Transfer Route. $\ldots \ldots \ldots \ldots \ldots \ldots \ldots \ldots$

5-8. Schedule. . . . . . . . . . . . . . . . . . 60

\section{LIST OF TABLES}

2-1. Acceptable Composition Ranges for Selected Phase I High-Level Waste Feed Components (DOE 1995a) . . . . . . . . . . . . . . . . . . . 3

2-2. Acceptable Physical Property Ranges for Selected Phase I High-Level Waste Feed Components (DOE 1995a) . . . . . . . . . . . . . . . . . 4 
WHC-SD-WM-ES-370

Revision 0

\section{LIST OF TABLES (CONTINUED)}

3-1. Base Case High-level Waste Sludge Recoveries for Phase I

High-Level Waste (Percent of Tank Inventory) $\ldots \ldots \ldots \ldots \ldots \ldots$

3-2. Range of Expected High-Level Waste Sludge Recoveries for Phase I. . . . . . . . . 9

3-3. Hanford Site 102-AY Estimated Heel Using Two 300-hp Mixer Pumps . . . . . . 10

3-4. Enhanced Sludge Washing--Caustic Leach Efficiencies $\ldots \ldots \ldots \ldots$

4-1. Mass of Waste in Each Source Tank for Phase I High-Level Waste Vitrification. . . 18

4-2. Range of Recovered Masses from Phase I Source Tanks. $\ldots \ldots \ldots \ldots$

4-3. Feed Slurry Ranges to Phase I High-Level Waste Vitrification (Base Case

Consolidation Scenario). . . . . . . . . . . . . . . . . 19

4-4. Estimated Phase I High-Level Waste Feed Oxide Quantity Ranges. . . . . . . . 20

4-5. Comparison of Selected Waste Constituents with the Draft Request for Proposals

Feed Envelope for High-Level Waste ("No Consolidation") . . . . . . . . . 23

4-6. Comparison of Selected Waste Constituents with the Draft Request for Proposals

Feed Envelope for High-Level Waste ("Mobilize 102-AY Solids"). . . . . . . . 24

4-7. Percent Reduction in Reference High-Level Waste

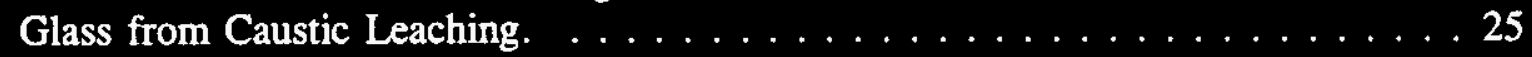

4-8. Effect of Alternative High-Level Waste Glass Formulations. . . . . . . . . . 26

4-9. Effect of Alternative High-Level Waste Glass

Formulations and Pretreatment Strategies. . . . . . . . . . . . 27

4-10. Impact of the Number of Washes in the Pretreatment of

Phase I High-Level Waste (Composition Variation Study Glass Limits) . . . . . 28

4-11. Low-Level Waste Volume Impacts of the Phase I High-Level Waste

Pretreatment Strategy (Dilute Caustic Washing) $\ldots \ldots \ldots \ldots \ldots$

4-12. Low-Level Waste Volume Impacts of the Phase I High-Level Waste

Pretreatment Strategy (Caustic Leaching) $\ldots \ldots \ldots \ldots \ldots \ldots$

5-1. High-Level Waste Demonstration Alternatives. . . . . . . . . . . . . 38 


\section{WHC-SD-WM-ES-370 \\ Revision 0 \\ LIST OF TABLES (CONTINUED)}

5-2. Transfer Routing for Alternative $1 . \ldots \ldots \ldots \ldots \ldots \ldots \ldots \ldots$

5-3. Transfer Route for Alternative $2 . \ldots \ldots \ldots \ldots \ldots \ldots \ldots \ldots$

5-4. Alternative 3 Transfer Route. . . . . . . . . . . . . . . 49

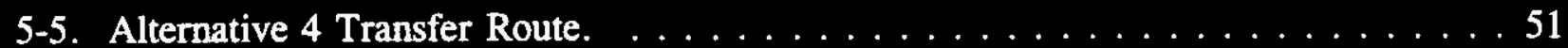

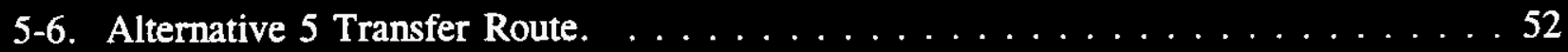

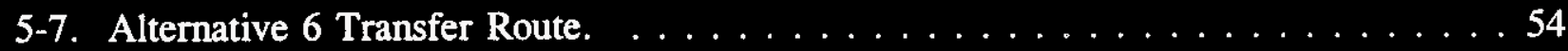


WHC-SD-WM-ES-370

Revision 0

\section{LIST OF TERMS}

$\begin{array}{ll}\text { EA } & \text { Environmental assessment } \\ \text { CCC } & \text { Canister Centerline Cooled } \\ \text { CVS } & \text { Composition Variation Study } \\ \text { DOE } & \text { U.S. Department of Energy } \\ \text { DOE-HQ } & \text { U.S. Department of Energy-Headquarters } \\ \text { DOE-RL } & \text { U.S. Department of Energy-Richland Operations Office } \\ \text { ESP } & \text { Environmental Simulation Program } \\ \text { HLW } & \text { High-level waste } \\ \text { LLW } & \text { Low-level waste } \\ \text { NCAW } & \text { Neutralized Current Acid Waste } \\ \text { OWVP } & \text { Operational Waste Volume Projection } \\ \text { PCT } & \text { Product Consistency Test } \\ \text { PHMC } & \text { Project Hanford Management Contractor } \\ \text { PNNL } & \text { Pacific Northwest National Laboratory } \\ \text { PUREX } & \text { Plutonium-Uranium Extraction } \\ \text { RFP } & \text { Request for Proposals } \\ \text { SAR } & \text { Safety Analysis Report } \\ \text { SORWT } & \text { Sort on Radioactive Waste Type } \\ \text { TCR } & \text { Tank Characterization Report } \\ \text { TWRS } & \text { Tank Waste Remediation System } \\ \text { WHC } & \text { Westinghouse Hanford Company }\end{array}$


WHC-SD-WM-ES-370

Revision 0

\section{PHASE I HIGH-LEVEL WASTE PRETREATMENT \\ AND FEED STAGING PLAN}

\subsection{OBJECTIVE}

The objective of the Phase I High-Level Waste Pretreatment and Feed Staging Plan is to determine a strategy for preparing and delivering a high-level waste (HLW) feed to the Phase I private contractor. The HLW feed must meet certain requirements with regard to quantity, composition, and physical properties. These requirements are specified in the draft release of the U.S. Department of Energy (DOE) Tank Waste Remediation System (TWRS) Request for Proposals (RFP) (DOE 1995a). A comparison of the estimated compositions of pretreated HLW with feed envelope specifications currently described in the draft RFP is included in Appendix B. Based on this assessment, the recommended changes to the HLW feed envelope specifications for the final RFP are provided.

This document recommends a preliminary transfer system architecture and operating scenario for the delivery of the pretreated, high-heat, and aging waste sludge to the Phase I HLW vitrification facility. A discussion is provided for the preferred transfer route (via underground pipelines and process pits), equipment and operating constraints (pumps, piping, valves, etc.), and a preliminary target schedule for the transfers. Eight alternative waste transfer routings and their associated requirements are evaluated (Chapter 5.0). Revisions to this preliminary feed staging plan will be conducted as program assumptions are verified or as necessary to reflect modifications to program assumptions. The next planned revision to the Phase I High-Level Waste Pretreatment and Feed Staging Plan is scheduled for completion on August 30, 1996 (U.S. Department of Energy-Richland Operations Office [DOE-RL] Milestone T33-96-235).

\subsection{BACKGROUND AND SCOPE}

As an option in Phase I of the TWRS Privatization RFP, the private contractor will conduct a demonstration of HLW vitrification technology. It will be the responsibility of the private contractor to develop, finance, construct, own, operate, decontaminate and decommission, and close the HLW demonstration facility as described in the draft RFP issued by the DOE in November 1995 . The DOE will pay a fee for these services under a fixed-price contract (DOE 1995a).

The candidate feeds for the Phase I HLW vitrification demonstration include the aging wastes stored in double-shell tanks (DSTs) 241-AZ-101 (101-AZ) and 241-AZ-102 (102-AZ), and high-heat sludge from single-shell tank (SST) 241-C-106 (106-C). A fraction of the 106-C solids are transferred into 241-AY-102 (102-AY), and then transferred into 101-AZ by the 102-AY transfer pump. Assuming no new pumps are installed, a fraction of the 106-C 


\section{Revision 0}

solids and all of the 102-AY solids are left behind in the transfer from 102-AY. A separate case is evaluated that assumes some mobilization of $102-\mathrm{AY}$ solids by installing mixer pumps. After pretreatment, characterization, and transfer into the private vendor's feed tanks by the Project Hanford Management Contractor (PHMC), the waste will be vitrified and packaged by the HLW private contractor. The vitrified HLW glass will ultimately be returned to the DOE in a form suitable for geologic disposal.

The Phase I High-Level Waste Pretreatment and Feed Staging Plan evaluates the preparation of a HLW feed from the high-heat sludges, and evaluates eight alternatives and system requirements for delivering the Phase I HLW feed to the private contractor feed tank(s). A recommendation is provided for the preferred transfer system alternative. Based on this recommendation, a preliminary time-phased, step-by-step plan for providing Phase I HLW feed is included. Cost estimates and a detailed schedule will be included in a future revision of this document.

This study is part of an integrated effort that includes the Preliminary Low-Level Waste Feed Staging Plan (Certa et al. 1996), the Operational Waste Volume Projection (Koreski and Strode 1995), and the NCAW Consolidation Management Plan (Powell 1996). Future revisions to the assumptions in these documents, and any other new issues, will be integrated into the August 1996 update.

\subsection{PURPOSE AND NEED}

The development and evaluation of the options associated with pretreating and staging the Phase I HLW solids provides input to the development of the final RFP requirements. The processing of HLW for vitrification and the minimization of disposal costs are crucial elements of the TWRS mission. A demonstration of HLW pretreatment and vitrification technologies is necessary to identify the requirements, issues, and potential risks. To perform this demonstration, a definition of the HLW pretreatment requirements and feed staging plan must be prepared. The information contained in this document supports the decision process by establishing the HLW feed staging criteria that encompass estimates of feed inventory and pretreatment requirements. 
WHC-SD-WM-ES-370

Revision 0

\subsection{SUMMARY}

The DOE has sufficient HLW feed and the means to provide feed to the privatization contractor during Phase I. The initially available HLW feed totals about twice the minimum feed requirements. The flexibility of the current infrastructure within tank farms provides a variety of methods to transfer the feed to the privatization contractor site location. The amount and type of pretreatment (sludge washing) necessary for the Phase I processing can be tailored to support the demonstration goals without having a significant impact on glass volume (i.e., either inhibited water or caustic leaching can be used).

Table 2-1 shows the estimated Phase I HLW feed composition versus the minimum and maximum concentrations. This estimate assumes all wastes are blended together as discussed in the Double-Shell Tank Waste Consolidation and Retrieval Planning Base Case (Bacon 1995). Based on this assessment, a revision of the RFP HLW feed specification is recommended. A discussion of the proposed changes to the RFP is included in Appendix B following the Feed Envelope Assessment. It is recommended that these changes be made before the issuance of the final RFP.

Table 2-1. Acceptable Composition Ranges for Selected Phase I High-Level Waste Feed Components (DOE 1995a).

\begin{tabular}{|c|c|c|c|c|}
\hline Component & $\begin{array}{c}\text { Minimum } \\
\text { concentration } \\
(\mathrm{g} / \mathrm{L})\end{array}$ & $\begin{array}{c}\text { Estimated } \\
\text { concentration } \\
(\mathrm{g} / \mathrm{L})\end{array}$ & $\begin{array}{c}\text { Maximum } \\
\text { concentration } \\
(\mathrm{g} / \mathrm{L})\end{array}$ & $\begin{array}{c}\text { Revised } \\
\text { maximum } \\
\text { concentration } \\
(\mathrm{g} / \mathrm{L})\end{array}$ \\
\hline Aluminum & 1.00 & 2.94 & 3.30 & 5.30 \\
\hline Chromium & 0.04 & 0.07 & 0.25 & 0.42 \\
\hline Iodine & 0.00 & 0.0000303 (high) & 0.0000014 & 0.001 \\
\hline Iron & 3.30 & 5.36 & 8.90 & 13 \\
\hline Phosphorus & 0.01 & 0.14 & 0.19 & 0.54 \\
\hline Sodium & 3.00 & 5.49 & 6.00 & 9.2 \\
\hline Thallium & 0.00 & 0.10 (high) & 0.083 & 0.14 \\
\hline Zirconium & 0.02 & 0.90 & 2.80 & 4.6 \\
\hline${ }^{14} \mathrm{C}$ & 0.00 & $0.00000168 \mathrm{Ci} / \mathrm{L}$ & $0.000001 \mathrm{Ci} / \mathrm{L}$ & $0.000002 \mathrm{Ci} / \mathrm{L}$ \\
\hline & & & & \\
\hline
\end{tabular}


Table 2-2 shows the physical properties of the feed versus the specification ranges. An assessment of the other HLW physical properties (e.g., viscosity, yield stress, heat capacity, etc.) is not performed, and will be included in a future draft. However, pretreated HLW transferred to the private contractor facility will be conditioned to meet the transfer system requirements for physical properties, as defined in the TWRS Functions and Requirements (WHC 1995).

Table 2-2. Acceptable Physical Property Ranges for Selected Phase I High-Level Waste Feed Components (DOE 1995a).

\begin{tabular}{|c|c|c|c|}
\hline Physical property & Minimum & Estimated & Maximum \\
\hline $\begin{array}{c}\text { Total solids mass } \\
\text { (oxide basis } \\
\text { excluding sodium } \\
\text { and silicon) }\end{array}$ & $190,000 \mathrm{~kg}$ & $\begin{array}{c}241,000 \mathrm{~kg} \\
\text { (minimum) to } \\
3555,000 \mathrm{~kg} \\
\text { (maximum) }\end{array}$ & $\mathrm{NA}$ \\
\hline Solids concentration & $2.5 \mathrm{wt} \%$ & $2.5 \mathrm{wt} \%$ & $13 \mathrm{wt} \%$ \\
\hline $\mathrm{pH}$ & $>10$ & 13 & $\mathrm{NA}$ \\
\hline Water content & $87 \mathrm{wt} \%$ & $97.5 \mathrm{wt} \%$ & $97.5 \mathrm{wt} \%$ \\
\hline
\end{tabular}

A preliminary transfer system architecture has been identified as a feasible path for delivering the Phase I HLW feed to the private contractor. This concept uses existing 3-in. supernatant transfer lines in the A Farm Complex Waste Transfer System and a proposed new 3-in. transfer line (included in the scope of Project W-314) to transfer the waste slurry to the private contractor's facility. The requirements for this system and a discussion of alternative routings are outlined in Chapter 5.0.

Interaction requirements with low-level waste (LLW) operations and other operations of DSTs in the A Farm Complex are considered in this preliminary evaluation and also will be addressed in the August 1996 revision of this document. In this analysis, interactions with LLW feed staging should have a minimal effect on the HLW feed slurry transfers in Phase I. Transfer routings that do not use a dedicated tank in AP Farm are described in Chapter 5.0. Figure 2-1 (Alternative 8) is a schematic of the recommended Phase I HLW feed transfer system.

For planning, it is recommended that pretreatment of the high-heat and aging waste sludges consist of a minimum of one dilute caustic $(0.1 M \mathrm{NaOH})$ wash (i.e., inhibited water), in addition to the sludge dissolution (wash) that occurs upon retrieval. These pretreatment steps will remove excess sodium from the slurry feed to HLW. As a result of the $20 \mathrm{wt} \%$ sodium oxide limit in the reference CVS glass composition (Hrma et al. 1994), the dilute caustic wash will remove the excess sodium from the feed to generate 41 percent less glass compared with no dilute caustic washes (Table 4-9). This wash also brings the feed concentration below the draft RFP specification of $6.0 \mathrm{~g} \mathrm{Na} / \mathrm{L}$ maximum (DOE 1995a). 
WHC-SD-WM-ES-370

Revision 0

Figure 2-1. Proposed Phase I High-Level Waste Feed Transfer System.
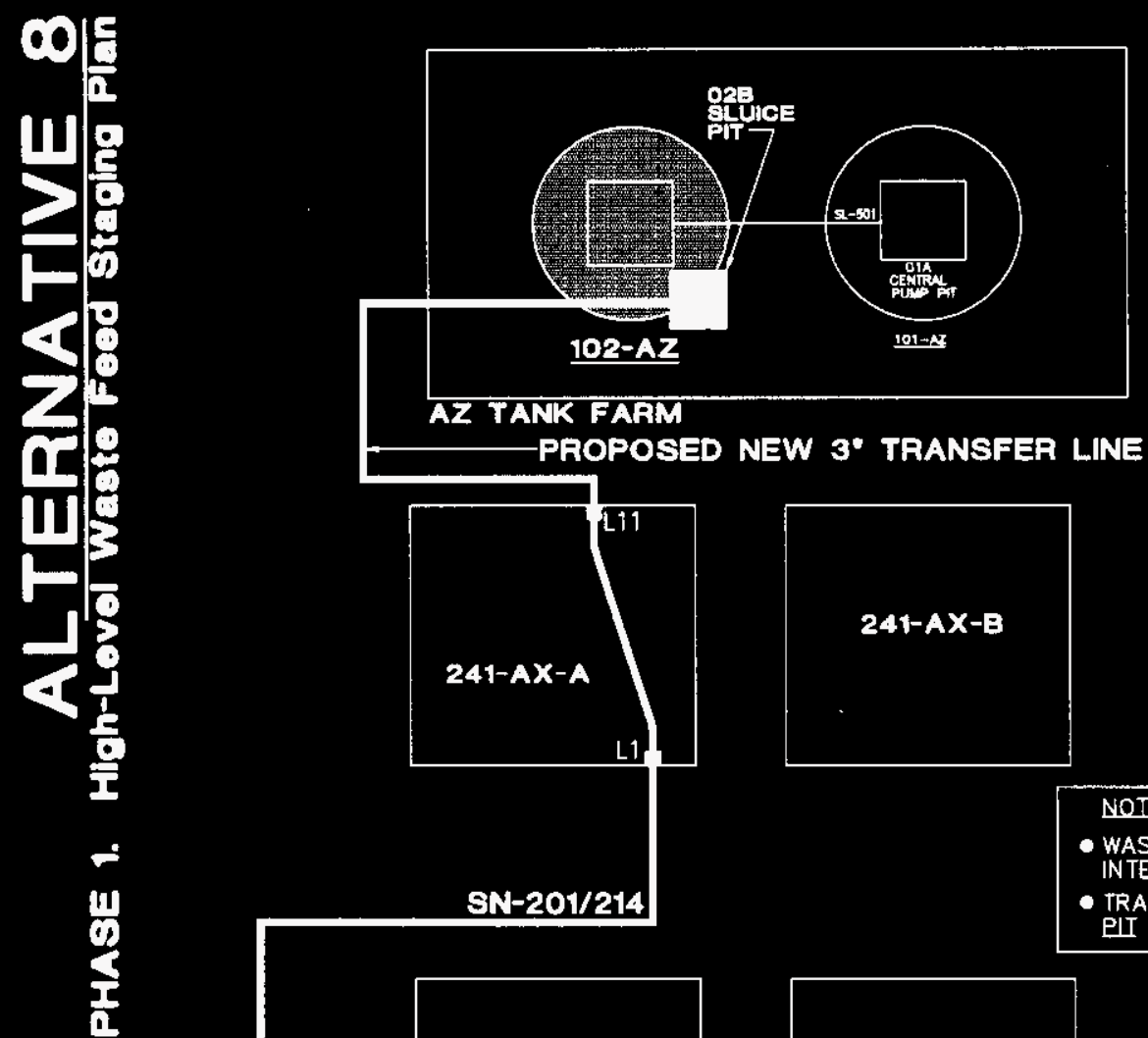

NOTE:

- WASTE IS NOT

INTERMEDIATE STAGED.

$8 N-201 / 214$

- TRANSFER USES TRANSFER PII ONLY FOR HLW TRANSFER.
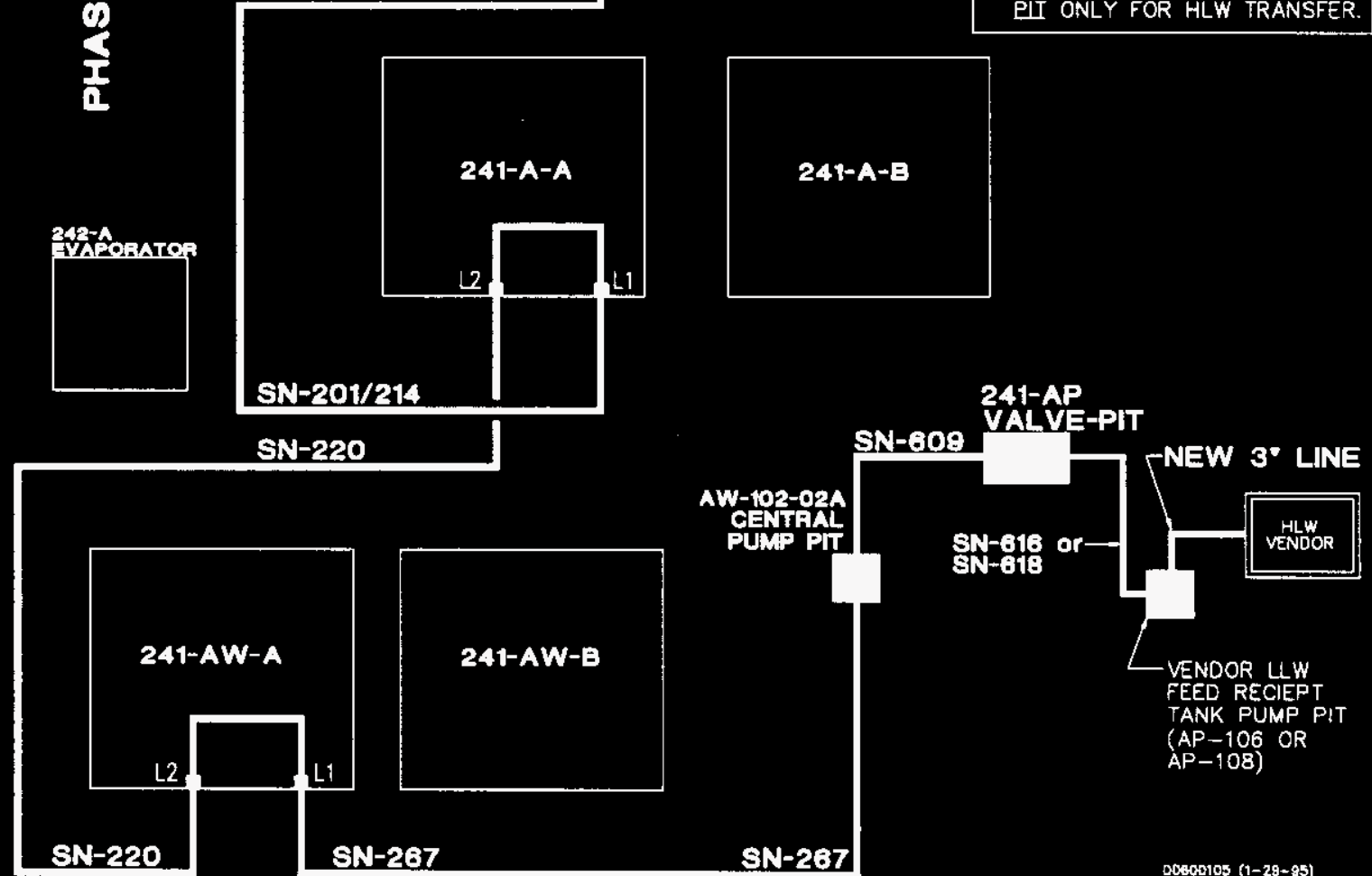
Based on current analyses of potential glass formulations and best estimates of tank inventories, there may be little or no benefit from caustic leaching in terms of glass volume reduction (i.e., glass volumes are not significantly reduced by caustic leaching). However, based on the uncertainty of the tank compositions and glass formulations, there may be some incentive for caustic leaching (e.g., $3 \mathrm{M} \mathrm{NaOH}$ ) to reduce aluminum in the waste feed (see Section 4.4 and Appendix D). Additionally, a demonstration of caustic leaching technology may be important, irrespective of glass volume reduction.

The process information obtained from conducting a caustic leaching technology demonstration may be beneficial to mitigating program uncertainties/risks associated with Phase II processing of tank wastes. The program uncertainties and risks are discussed in the U.S. Department of Energy-Headquarters' (DOE-HQ) TWRS Systems Requirements Review (DOE 1995b). Therefore, dilute caustic washing is recommended, but the option for caustic washing should be preserved in Phase I HLW pretreatment. 
WHC-SD-WM-ES-370

Revision 0

\subsection{ASSUMPTIONS AND METHODS OF ANALYSIS}

This chapter describes the assumptions used in this evaluation. Best estimates of tank waste inventory, sludge consolidation, waste pretreatment, HLW glass formulations, and the status of thermodynamic modeling are discussed. A definition is provided for a range of retrieved sludge and process efficiencies used for this analysis. The assumptions and ranges used in this analysis are to bound the uncertainties in the HLW processing and feed staging parameters. A formal risk assessment has yet to be performed to help to determine the preferred case.

\subsection{TANK WASTE INVENTORY}

The candidate sludge feeds for Phase I HLW are Neutralized Current Acid Waste (NCAW) from 101-AZ and 102-AZ and high-heat sludge retrieved from 106-C into 102-AZ via 102-AY. Retrieval of sludge from 102-AY is not assumed in the base case scenario. The impacts of retrieving a fraction of 102-AY are discussed in a separate case. NCAW is the HLW generated from the first cycle solvent extraction process from the PlutoniumUranium Extraction (PUREX) plant. SST 106-C contains metal waste from the bismuth phosphate process, and PUREX supernatant and sludge wash waste from 244-AR vault. It received large amounts of strontium, resulting in a high-heat load that requires water additions and ventilation for cooling.

The tank waste inventories used in this analysis consist of the best analytical information available. For SST 106-C, and DSTs 101-AZ and 102-AZ, the inventories and solubility data represent a change from the values reported in the TWRS Process Flowsheet (Orme 1995). The revised inventory assumptions will be integrated into the next release of the flowsheet. Tables A-1 through A-3 of Appendix A contain the revised inventory assumptions for the Phase I HLW source tanks. The 102-AY inventory is consistent with the TWRS Process Flowsheet and is shown in Table A-4 of Appendix A.

The flowsheet models all of the SSTs as one global inventory and allocates the global inventory to individual tanks using a calculated model (Agnew 1994a and 1994b). For purposes of the flowsheet, the global modeling does not alter the results when the SSTs are taken as a whole. However, for the processing of a single tank, such as in this analysis for 106-C, it can have a significant impact on the outcome and the inventory assumptions must come from lab analyses (Weiss 1988). For DSTs 101-AZ and 102-AZ, the inventories are revised based upon a reevaluation of core sample data, Tank Characterization Reports (TCRs), lab analyses, and historical records. Appendix D includes a discussion of the assumptions, uncertainties, and references used for the revised inventories. 


\subsection{PROCESS PARAMETERS FOR WASTE CONSOLIDATION}

The following section details the processing parameters that are considered in this analysis. The HLW feed staging plan interfaces with other activities such as high-heat and aging waste sludge consolidation (i.e., retrieval and pretreatment), the HLW feed specifications, and the HLW glass formulation. To analyze the sensitivities to these parameters, a high- and a low-range value are evaluated. This range will be narrowed as further analyses continue.

\subsubsection{Consolidation of High-Heat Sludge and Aging Waste}

The Double-Shell Tank Waste Consolidation and Retrieval Planning Base Case (Bacon 1995) describes the base case scenario for the consolidation of high-heat and aging waste sludges. In this scenario, technology demonstrations of retrieval and in-tank sludge washing are planned for NCAW, also referred to as aging waste, from tanks 101-AZ and 102-AZ and high-heat sludge retrieved into $101-\mathrm{AZ}$ (via 102-AY) from 106-C. In the final sludge consolidation, the pretreated solids are combined in tank 102-AZ and are scheduled to be available for transfer to the private contractor at the beginning of fiscal year 2002 .

The base case distribution of source tanks consolidated in tank 102-AZ is based on the transfers described in the Double-Shell Tank Waste Consolidation and Retrieval Planning Base Case (Bacon 1995) and the minimum sludge retrieval fractions. The percentages of each source tank are shown in Table 3-1.

Table 3-1. Base Case High-level Waste Sludge Recoveries for Phase I High-Level Waste (Percent of Tank Inventory).

\begin{tabular}{|c|c|c|c|}
\hline Phase I tank & Percent retrieval & $\begin{array}{c}\text { Percent heel (percent } \\
\text { loss in 102-AY) }\end{array}$ & $\begin{array}{c}\text { Percent consolidated } \\
\text { in tank 102-AZ }\end{array}$ \\
\hline $106-\mathrm{C}$ & 75 & 50 & 37.5 \\
\hline $102-\mathrm{AY}$ & 0 & -- & 0 \\
\hline $101-\mathrm{AZ}$ & 80 & -- & 80 \\
\hline $102-\mathrm{AZ}$ & 80 & -- & 100 (80 Retrieved) \\
\hline
\end{tabular}

As a basis, it is assumed that a minimum of 75 percent of the sludge is retrieved from tank 106-C into 102-AY (consistent with the Project W-320 planning basis), and 50 percent of that volume of 106-C (i.e., 37.5 percent of the original 106-C sludge volume) is recovered from 102-AY into 101-AZ. No 102-AY sludge is retrieved in the sludge transfer from 102-AY into 101-AZ. Sludges from 101-AZ and 102-AZ are combined, and a minimum of 80 percent of the combined AZ sludge plus the 37.5 percent of $106-\mathrm{C}$ are available for 
delivery into the private contractor feed tank(s) during Phase I. Refer to Bacon (1995) for detail on the base case sludge and supernate transfers. The above recovery fractions are preliminary allowances only.

There is uncertainty regarding the extent to which the sludge can be retrieved from each of the tanks. The efficiency will depend upon the operating constraints of the equipment in place and the physical characteristics of the sludge. This efficiency is an important matter because it has a direct impact on the quantity of feed available to the Phase I HLW contractor. Not only does it affect the design of the HLW vitrification facility, but also the operating requirements for staging the waste to the private contractor.

Alternative consolidation strategies and tradeoff studies are currently being reviewed (Powell 1996). For purposes of this study, the planning basis (Bacon 1995) with the minimum retrieval fractions and a case representing very efficient retrieval, are evaluated as bounding cases. The assumptions used in this evaluation represent a lower and upper bound for Phase I sludge consolidation, and the retrieval ranges are presented in Table 3-2.

Table 3-2. Range of Expected High-Level Waste Sludge Recoveries for Phase I.

\begin{tabular}{|c|c|c|c|}
\hline Phase I tank & Percent retrieval & $\begin{array}{c}\text { Percent heel (percent } \\
\text { loss in 102-AY) }\end{array}$ & Percent decant losses \\
\hline $106-\mathrm{C}$ & 75 to $95^{\mathrm{a}}$ & 50 to 25 & -- \\
\hline $102-\mathrm{AY}$ & 0 to $36^{\mathrm{a}}$ & -- & - \\
\hline $101-\mathrm{AZ}$ & 80 to 99 & -- & Small $(<0.5)$ \\
\hline $102-\mathrm{AZ}$ & 80 to 99 & -- & Small $(<0.5)$ \\
\hline
\end{tabular}

${ }^{2}$ The high value assumes the installation of 300-hp mixer pumps in 102-AY (Grams 1995). Shear strength measurements (Grams 1995) and 106-C retrieval plans suggest that the retrieval of appreciable amounts of 102-AY will require the installation of additional equipment.

"The "percent heel" represents the percentage of the retrieved sludge from tank 106-C that is left behind in 102-AY in the base case consolidation scenario.

3.2.1.1 Case for No Consolidation. This study also evaluates an alternative that does not consolidate sludges into 102-AZ. In the "no consolidation" case, three separate pretreated HLW batches (101-AZ, 102-AZ, and 102-AY plus 106-C) would be fed to the private contractor. The maximum heel remaining in each tank is conservatively estimated at 20 percent, based upon installing two mixer pumps in each tank to mobilize the solids. An upper bound for retrieval of these tanks, a 1 percent heel, is also evaluated.

This analysis examines the impact of the "no consolidation" case as an alternative bounding case. This will provide some perspective on the impacts and uncertainty ranges 
resulting from variations of the preferred consolidation case. The estimated HLW feed compositions and quantities on an individual tank basis are compared to the draft RFP specifications for HLW feed. Rather than assuming the sludge consolidation fractions in Tables 3-1 and 3-2, the Phase I source tanks are processed and transferred individually to determine if any one or two tanks can provide a sufficient quantity of feed within the HLW feed quantity and composition specifications.

The results of these assumptions, shown in Table 4-2, are used to provide a range of sludge recoveries only. Early estimates based on sludge shear strength measurements of the AZ tanks indicate that the minimum heels left in each of the tanks, assuming sludge mobilization with two 300-hp mixer pumps, are 3 percent and 40 percent, for $101-\mathrm{AZ}$ and 102-AZ, respectively (Grams 1995). If higher recovery fractions are desired, additional process equipment (e.g., sluicing systems) may be necessary. The shear strength measurements used in Grams (1995) can not be considered to be precise, and the actual percent of mobilized sludge may be different from the estimates provided in that document.

3.2.1.2 "Mobilize 102-AY Solids" Case. Table 3-3 below shows the estimated physical characteristics of the 102-AY solids based upon shear strength measurements (Grams 1995).

Table 3-3. Hanford Site 102-AY Estimated Heel Using Two 300-hp Mixer Pumps.

\begin{tabular}{|c|c|c|c|c|}
\hline Tank & Waste type & $\begin{array}{c}\text { Shear Strength } \mathrm{dy} / \mathrm{cm}^{2} \\
\left(\mathrm{lb} / \mathrm{tt}^{2}\right)\end{array}$ & $\begin{array}{c}\text { Effective cleaning } \\
\text { radius } / \% \\
\text { mobilized cm }(\mathrm{ft}) / \%\end{array}$ & Heel Kl (Kgal) \\
\hline 102-AY & $\begin{array}{c}\text { Dilute } \\
\text { noncomplexed }\end{array}$ & $31(64)$ & $488(16) / 36 \%$ & $76(20)$ \\
\hline
\end{tabular}

Equation: $\quad \mathrm{ECR}=\mathrm{K} \cdot \mathrm{U}_{0} \cdot \mathrm{D} \cdot \tau^{-\mathrm{n}}$

ECR - Effective Cleaning Radius (cm)

K - Constant (17.3)

$\mathrm{U}_{0} \cdot \mathrm{D}$ - Jet Velocity Times Jet Diameter $\left(27314 \mathrm{~cm}^{2} / \mathrm{s}\right)$

$\tau$ - Sludge Shear Strength $\left(\mathrm{dy} / \mathrm{cm}^{2}\right)$

n - Experimental Constant (0.67).

Using two 300 -hp mixer pumps retrieves only 36 percent of the $102-A Y$ sludge based on a sludge shear strength of $31,000 \mathrm{dy} / \mathrm{cm}^{2}$. This would provide the maximum case limit of blending approximately $76,000 \mathrm{~L}$ of $102-\mathrm{AY}$ sludges with the $106-\mathrm{C}$ solids. This case would assume that the two mixer pumps completely remobilize the $106-\mathrm{C}$ solids. To evaluate the impacts of mobilizing 36 percent of $102-A Y$ on HLW feed composition, the minimum recovery fractions for the other source tanks in Table 3-2 are used ("worst case"). These impacts are small as discussed in Section 4.3.1.3.

A small fraction of the solids from 102-AY may be incidentally mobilized by other mechanisms during the 106-C sluicing operation. The amount of 102-AY sludge incidentally mobilized by the returning slurry from the 106-C sluicing operations can be evaluated by comparing the slurry exit velocity and pipe diameter to the jet velocity and nozzle diameter of the 300-hp mixer pump: 
Sluicing operations will require $1,136 \mathrm{~L} / \mathrm{min}$ ( $300 \mathrm{gal} / \mathrm{min})$ per sluicing nozzle. Two sluicing nozzles operating simultaneously will provide $2,271 \mathrm{~L} / \mathrm{min}(600 \mathrm{gal} / \mathrm{min})$ of return fluid back to 102-AY. This would be a bounding case. The return pipe (nominal 3-in. diameter) at maximum flow for two sluicers would have an exit velocity $\left(\mathrm{U}_{0}\right)$ of $829 \mathrm{~cm} / \mathrm{s}$ (27.2 fps). The exit diameter of the pipe is $7.79 \mathrm{~cm}(3.068 \mathrm{in}$.) for standard strength steel pipe. The $U_{0} D$ ratio of the maximum return sluice slurry would then be $6,458 \mathrm{~cm}^{2} / \mathrm{sec}$ $\left(6.95 \mathrm{ft}^{2} / \mathrm{sec}\right)$. This $\mathrm{U}_{0} \mathrm{D}$ for the return pipe is 24 percent of the $\mathrm{U}_{0} \mathrm{D}$ for the two 300 -hp mixer pumps. Furthermore, note that there would be 4 nozzles for the two mixer pumps which makes the total flow of the returned sluice material only one fourth of the 24 percent, or 6 percent. Thus, for the maximum bounding case, the returned sluice material would only retrieve 6 percent of that of two 300-hp mixer pumps (i.e., 6 percent of 36 percent of the 102-AY solids). This would occur if the sluice return was done at the bottom of the tank with the jet exit angled at the most advantageous angle and rotated through 360 degrees.

As planned, the sluice material will be added at the top of the tank through a slurry spreader which greatly reduces the exit velocity and angles it away from the sludge in the bottom of the tank. Therefore, there will be little, if any, 102-AY sludge mobilized by the returned sluicate.

Another possibility for inclusion of some 102-AY sludge with the 106-C slurry occurs when using a small mixer pump (75 hp) to maintain a uniform slurry in tank 102-AY. Similarly, a single smaller mixer pump would pick up only a small fraction of what two 300-hp mixer pumps would take. This amount is reduced to essentially zero when the smaller mixer pump is located such that the jets are well above the sludge layer, directed into the slurry layer.

\subsubsection{Phase I High-Level Waste Pretreatment}

Meeting the Phase I HLW feed criteria depends upon the composition of the waste, and also to a large extent, the solubility effects of the HLW pretreatment process (in-tank sludge washing). For this study, the best estimates using recent lab testing combined with tank inventory estimates based on analytical data are used to model the chemical behavior of the Phase I sludges in the pretreatment process. A comparison with the results of current efforts using more rigorous chemical thermodynamic modeling and alternative inventory assumptions (sensitivity studies) are deferred to the update of the Phase I HLW Pretreatment and Feed Staging Plan scheduled to be issued in August 1996.

Another goal for the pretreatment of Phase I HLW sludge is to minimize the volume of HLW glass produced, while providing at least the minimum sludge volume of waste as specified in the draft RFP (equivalent to 190 MT of waste oxides, excluding sodium and silicon) for the Phase I HLW vitrification demonstration. Minimizing the HLW glass volume will minimize the cost for geologic disposal. For HLW glass limited by aluminum, chromium, phosphorus, or sodium oxides, the amount of glass may be reduced by in-tank sludge washing with caustic. An added benefit is that a demonstration of the pretreatment 


\section{WHC-SD-WM-ES-370 \\ Revision 0}

process will provide better estimates of the effect of caustic leaching in the processing of the remaining tank waste. The issue of depleting tank storage space with large additions of wash solution is addressed in Section 4.6.5.

The minimum processing required to prepare the Phase I HLW feed is evaluated. This analysis examines the effects of dilute caustic washing and caustic leaching of the Phase I sludge, and describes the impacts on feed composition and glass product volumes. Settle/decant operating assumptions and efficiencies for in-tank sludge washing are consistent with the TWRS Process Flowsheet (Orme 1995).

3.2.2.1 Water Wash Solubility Factors. Appendix A contains the revised soluble and insoluble component masses for each tank based on the TWRS Process Flowsheet and other analytical data explained below. The water wash factors are based on laboratory testing.

The results obtained from water washing of the core composites are used to determine the solubility of each component for the Phase I HLW source tanks. For each component, the amount removed from the sludge is assumed to be equal to the amount found in the wash solution(s) divided by the sum of the soluble mass and the amount left in the washed solids. For the majority of the components, the mass balances are not in total agreement. However, for all of the major components, including aluminum, chromium, iron, and sodium, the mass balances are within 15 percent. The water wash factors (or efficiencies) for NCAW are taken from tank characterization reports for 101-AZ and 102-AZ (Gray et al. 1993a, Gray et al. 1993b, and Peterson et al. 1989). Because of poor mass balances in the analyses, the processing of HLW sludge may be highly dependent upon the methodology for calculating solubility factors. A sensitivity study to examine the impacts of using alternative water solubility factors will be included in the August 1996 update to this plan.

Water solubility factors for 106-C are based upon data presented by Weiss (1988). Where wash data are unavailable, the flowsheet assumptions for SST waste components are used. Table A-1 in Appendix A shows the water soluble and insoluble component masses for 106-C.

In the recommended case, the sludges undergo one dilute caustic wash in addition to the retrieval "wash." The composition is shown in the shaded column of Table B-1. Sludges from 101-AZ, 102-AZ, and 106-C are blended together according to Tables 3-1 and 3-2. The blended waste compositions (at $31 \mathrm{~g}$ oxides $/ \mathrm{L}$ ) to be transferred to the Phase I HLW contractor are presented in Tables B-1 and B-2 of Appendix B as part of the HLW Feed Envelope Assessment.

3.2.2.2 Caustic Wash Solubility Factors. The caustic leach efficiencies (percent removal from the solid phase) assumed for this study are shown in Table 3-4, and are consistent with Orme (1995). 
WHC-SD-WM-ES-370

Revision 0

Table 3-4. Enhanced Sludge Washing--Caustic Leach Efficiencies. ${ }^{a}$

\begin{tabular}{|c|c|c|c|}
\hline High-heat tank & Aluminum & Chromium & Phosphate \\
\hline $106-\mathrm{C}$ & $48 \%$ & $66 \%$ & $11 \%$ \\
\hline $101-\mathrm{AZ}$ & $85 \%$ & $75 \%$ & $70 \%$ \\
\hline $102-\mathrm{AZ}$ & $85 \%$ & $75 \%$ & $70 \%$ \\
\hline
\end{tabular}

These caustic leach efficiencies and the associated compositions in Appendix B should be regarded as preliminary allowances only. Phase I testing of sludges is currently being conducted, and the results will be included in the August 1996 document update.

No analytical data are currently available for the caustic washing of 106-C. Therefore, in the absence of this data, the caustic leach efficiencies for 106-C are assumed to be the same as those determined from testing 241-C-103 (103-C) samples. Single-shell tank 106-C is assumed to contain similar waste as 103-C (Brevick 1994). Tanks 101-C through 106-C all received metal waste from the bismuth phosphate process. Tanks C-103 and C-106 both received strontium leached sludge and are grouped under the same category (Group XIX) in the Sort on Radioactive Waste Type (SORWT) model (Hill et al. 1995). Therefore, the caustic leach factors obtained from experimental data for 103-C (Rapko et al. 1995) are assumed to be applicable to 106-C for this study.

The caustic leach factors assumed for 101-AZ and 102-AZ are the same as the global average DST caustic leach factors assumed in the TWRS Process Flowsheet (Orme 1995). The percentages leached from the sludge are assumed to be 85 percent, 75 percent, and 70 percent for aluminum, chromium, and phosphate, respectively. Preliminary data suggest lower leach efficiencies (Herting 1995). The validity of the experimental data is currently being evaluated and the factors assumed here may be revised in a future release of this document. However, it is shown, based on the assumptions in this evaluation, that caustic leaching (regardless of leach efficiency) may have little or no benefit to reducing glass volumes (see Section 4.4).

\subsubsection{High-Level Waste Product Criteria}

The following requirements for Vitrified High-Level Waste are derived from Specification 1 of the draft RFP (DOE 1995a). The HLW form shall be a borosilicate glass.

1. The HLW shall be packaged in a $0.61-\mathrm{m}$ diameter by $3-\mathrm{m}$ long austenitic stainless steel canister, filled with glass to at least $0.6 \mathrm{~m}^{3}$ or 80 percent of the internal volume of the empty canister, whichever is greater, be void of free liquids, pyrophoric, combustive or explosive materials (49 CFR 173), be subcritical under all conditions, have a maximum product temperature less than $400{ }^{\circ} \mathrm{C}$ after initial cooling, and have a maximum heat generation less than $1,500 \mathrm{~W} /$ canister. 
2. The normalized release of boron, lithium, sodium and silicon from the HLW form as determined by a Product Consistency Test shall be less than the release of these elements from the reference Environmental Assessment (EA) glass (DOE/EA-0179).

3. The HLW form shall contain as a minimum, averaged over the immobilization run of a given waste feed, 25 percent by weight of non-volatile components originating in the feed on an equivalent oxide basis. No credit shall be given for $\mathrm{Na}_{2} \mathrm{O}$ and $\mathrm{SiO}_{2}$ in the waste feed toward the calculated percent waste loading in the product glass.

4. Waste glass (product) samples shall be taken during production and provided to DOE for independent confirmation testing of compliance with acceptance specifications.

5. The HLW qualification program shall be developed in accordance with the QA requirements.

Items 1 and 3 above are considered in this evaluation. The net storage capacity for a reference canister is assumed to be $0.62 \mathrm{~m}^{3}$.

\subsubsection{Alternative High-Level Waste Glass Formulations}

The HLW glass formulation (for a borosilicate glass) depends on the type of melter selected, the composition of the waste, and other parameters. It also affects the maximum waste oxide loading and the total volume of glass produced. Since the melter design depends on the private contractor, a range in the predicted HLW glass volumes is represented. Two different glass formulations are evaluated for low-temperature $\left(1150^{\circ} \mathrm{C}\right)$ melters (see Appendix C, Table C-11). The low-temperature glass formulations for HLW glass reported in the Composition Variation Study (CVS) (Hrma et al. 1994) and the HWVP Project Technical Data Package (Kalia 1994) are evaluated.

Another alternative glass formulation for a high-temperature melter $\left(>1350{ }^{\circ} \mathrm{C}\right)$ may have higher limits for several of the major glass constituents, such as $\mathrm{Na}_{2} \mathrm{O}$ and $\mathrm{Fe}_{2} \mathrm{O}_{3}$, and may produce a smaller volume of glass. The high-temperature glass formulation represents a bounding case and may lower the cost for disposal. High-temperature glass formulations are currently being reviewed and will be included in the August 1996 update to this document, if available. Compared with low-temperature vitrification, high-temperature vitrification technology is less mature and is associated with a greater uncertainty range.

Additional testing with simulated sludges and computer models is being conducted to determine alternative glass formulations and to evaluate glass properties. The glass formulations (compositions) presented in Appendix $\mathrm{C}$ do not necessarily guarantee a glass of good quality, but they do provide some sense of the bounding cases. The applicability of 
WHC-SD-WM-ES-370

Revision 0

new formulations that consider glass properties is currently under review, and the preliminary results are presented in Tables D-1 and D-2 in Appendix D.

\subsubsection{Thermodynamic Modeling Results}

The analysis of tank waste composition and solubility to date has used empirical factors developed from analytical data. Further work evaluating the thermodynamic properties of the tank waste is being performed using the Environmental Simulation Program $\left(E S P^{1}\right)$. These models will demonstrate the solubility constraints affecting the observed washing and leaching chemistry of sludge washing and caustic leaching. The extent to which key components such as aluminum, chromium, phosphorus, and sodium, are removed will be better estimated for varying feed compositions. These models are used to reconcile inconsistencies in analytical data (e.g., poor material balances). If thermodynamic modeling provides additional understanding of sludge component solubility, the results of thermodynamic modeling will be verified, reviewed, and integrated into this evaluation in a future release.

\subsection{PHASE I TRANSFER OF CONSOLIDATED HIGH-LEVEL WASTE ASSUMPTIONS}

In the base case, consolidated sludge in 102-AZ will be transferred to the private contractor in Phase I via underground pipelines. Efforts are currently underway to evaluate the system requirements and tradeoffs for each of the eight Phase I HLW transfer alternatives. Chapter $\mathbf{5 . 0}$ provides a preliminary definition of feasible waste transfer routings and the recommended alternative for the Phase I HLW.

\subsection{TANK SAFETY ISSUES}

The Safety Analysis Report (SAR) for the Hanford Site DSTs is being finalized. The sludge consolidation and pretreatment actions described in this plan will need to be evaluated to determine compliance with the finalized DST SAR, when available. Modifications to the safety basis and/or the sludge pretreatment and consolidation actions may be necessary.

The TWRS Program is continuing to evaluate the conditions of tank wastes to ensure proper controls are in place for safe storage. Evaluations of tanks 101-AZ and 102-AZ may lead to the addition of controls that could effect this plan. (Tank 102-AY has been separately evaluated for the receipt and storage of tank 106-C sludges). If this results, revision of this plan will be necessary.

${ }^{1}$ ESP is a trademark of OLI Systems, Inc. 
WHC-SD-WM-ES-370

Revision 0

This page intentionally left blank. 


\subsection{PHASE I HIGH-LEVEL WASTE PRETREATMENT STRATEGY}

A recommendation is provided for a pretreatment strategy for preparing an acceptable HLW feed in Phase I. The consolidation of high-heat sludge and aging waste is discussed, and the projected range of feed quantities is provided. Additional goals for the Phase I pretreatment process are to meet the RFP composition specifications for HLW, and to reduce the amount of HLW glass generated to the extent possible through the use of caustic and/or multiple dilute caustic washes. Base case projected glass volumes and compositions are presented in Appendix C, Tables C-1 through C-4. Tables C-5 through C-10 present the glass composition results from processing individual tanks in the "no consolidation" case.

\subsection{CONSOLIDATION OF HIGH-HEAT SLUDGE AND AGING WASTE}

An evaluation of the operational alternatives in the consolidation of Phase I HLW sludge is currently underway. The transfers described in the base case consolidation (Bacon 1995) are assumed for the sludge transfers. Due to the uncertainty in the preferred Phase I HLW consolidation basis, a range of fractional recoveries from each of the source tanks for the Phase I HLW feed is evaluated for this evaluation. It is assumed for the lower bounding case, the minimum sludge volume will be recovered from the Phase I tanks. Based on a range, a minimum of $328 \mathrm{~m}^{3}$ and a maximum of $516 \mathrm{~m}^{3}$ of dilute caustic washed sludge will be available in tank 102-AZ in Phase I for transfer to the HLW vitrification facility. This available quantity of sludge is greater than the minimum sludge quantity needed to meet the minimum draft RFP feed quantity of $190 \mathrm{MT}$ of waste oxides excluding sodium and silicon. The "no consolidation" case is also addressed in this section (see Sections 4.2 and 4.3).

\subsubsection{Consolidated Sludge Volumes}

The mass of waste, in terms of waste oxides (excluding sodium and silicon), available for feed to HLW totals $424,000 \mathrm{~kg}$. Table 4-1 lists the original masses of insoluble solids and the equivalent masses in terms of waste oxides, excluding sodium and silicon. The total does not include solids in tank 102-AY because current planning does not call for the recovery of these solids. The addition of 102-AY sludge (see Section 4.3.1.3) will increase the total available waste to $461,000 \mathrm{~kg}$ of waste oxides (excluding sodium and silicon). After consolidation and washing, the total can range between 241,000 and $355,000 \mathrm{~kg}$ (Table 4-2).

Based upon the base case consolidation scenario and the range of recovery fractions in Table 3-2 of Chapter 3.0, Table 4-2 lists the masses of sludge from each of the source tanks that are available for vitrification in Phase I. 
WHC-SD-WM-ES-370

Revision 0

Table 4-1. Mass of Waste in Each Source Tank for Phase I High-Level Waste Vitrification.

\begin{tabular}{|c|c|c|c|c|c|}
\hline & $106-\mathrm{C}$ & $102-\mathrm{AY}$ & $101-\mathrm{AZ}$ & $102-\mathrm{AZ}$ & Total \\
\hline $\begin{array}{c}\text { Mass of insoluble } \\
\text { solids in source tank }\end{array}$ & $715,000 \mathrm{~kg}$ & $75,500 \mathrm{~kg}$ & $132,000 \mathrm{~kg}$ & $188,000 \mathrm{~kg}$ & $\begin{array}{c}1,040,000 \mathrm{~kg} \\
\text { (excludes 102-AY) }\end{array}$ \\
\hline $\begin{array}{c}\text { Mass of equivalent } \\
\text { waste oxides } \\
\text { excluding sodium and } \\
\text { silicon in source tank } \\
\text { (dilute caustic washed) }\end{array}$ & $232,000 \mathrm{~kg}$ & $36,900 \mathrm{~kg}$ & $82,100 \mathrm{~kg}$ & $110,000 \mathrm{~kg}$ & $\begin{array}{c}424,000 \mathrm{~kg} \\
\text { (excludes } 102-\mathrm{AY} \text { ) }\end{array}$ \\
\hline
\end{tabular}

Table 4-2. Range of Recovered Masses from Phase I Source Tanks.

\begin{tabular}{|l|c|c|c|c|c|}
\hline & $106-\mathrm{C}$ & $102-\mathrm{AY}$ & $101-\mathrm{AZ}$ & $102-\mathrm{AZ}$ & Total \\
\hline $\begin{array}{l}\text { Mass of insoluble } \\
\text { solids to high-level } \\
\text { waste }\end{array}$ & $\begin{array}{c}268,000 \mathrm{to} \\
509,000 \mathrm{~kg}\end{array}$ & 0 to $27,200 \mathrm{~kg}$ & $\begin{array}{c}106,000 \mathrm{to} \\
131,000 \mathrm{~kg}\end{array}$ & $\begin{array}{c}150,000 \mathrm{to} \\
186,000 \mathrm{~kg}\end{array}$ & $\begin{array}{c}524,000 \mathrm{to} \\
826,000 \mathrm{~kg} \\
\text { (excludes 102-AY) }\end{array}$ \\
\hline $\begin{array}{l}\text { Mass of equivalent } \\
\text { waste oxides } \\
\text { excluding sodium } \\
\text { and silicon to high- } \\
\text { level waste (dilute } \\
\text { caustic washed) }\end{array}$ & $\begin{array}{c}87,000 \mathrm{k} \text { to } \\
165,000 \mathrm{~kg}\end{array}$ & 0 to $13,300 \mathrm{~kg}$ & $\begin{array}{c}65,700 \mathrm{to} \\
81,300 \mathrm{~kg}\end{array}$ & $\begin{array}{c}88,000 \text { to } \\
109,000 \mathrm{~kg}\end{array}$ & $\begin{array}{c}241,000 \text { to } \\
355,000 \mathrm{~kg} \\
\text { (excludes } 102-\mathrm{AY} \text { ) }\end{array}$ \\
\hline
\end{tabular}

The minimum recovery fractions listed in Tables 3-1 and 3-2 of Chapter 3.0 are applied to the base case consolidation scenario (Bacon 1995) to arrive at the totals shown in Table 4-2. When the maximum values are used, the calculations are referred to as the maximum retrieval case, as in Section 4.5.2 (Figures 4-1 through 4-4), and Appendixes B and $C$. Similarly, when minimum values are used, the calculations are referred to as the minimum retrieval case.

In this evaluation, a minimum of $241 \mathrm{MT}$ of waste oxides, excluding sodium and silicon, are produced from consolidating, pretreating, and vitrifying the available Phase I sludge (assuming the base case consolidation scenario with minimum retrieval). Section B of the draft RFP states that for the Phase I HLW option, a fee will be paid for waste processing services of a minimum of 190 MT of waste oxides exclusive of the sodium and silicon in the feed. Currently, no maximum quantity of waste oxides has been specified. A blended, pretreated HLW feed composed of high-heat and aging waste sludge has been identified for Phase I that meets the target waste oxide quantity minimum. Because the minimum sludge required is less than the expected minimum sludge recovered, there is an excess in sludge available for Phase I. In Table 4-3, the estimated mass and volume of waste are given in terms of a range based on the achievable recovery fractions from each of the source tanks. 


\section{WHC-SD-WM-ES-370}

\section{Revision 0}

It is important to note that if consolidation of sludges into tank $102-\mathrm{AZ}$ does not occur, waste sludges can be supplied from each of the three DSTs, individually. Referring to Table 4-1, the minimum mass of dilute caustic washed sludges will still provide a feed in excess of $190 \mathrm{MT}$ of oxides excluding sodium and silicon, with a 20 percent sludge heel (refer to Section 4.2). Section 4.2.2 provides further discussion of the "no consolidation" case.

\subsubsection{Sludge Transfer Volumes}

The volume of sludge will be transferred to the private contractor with some volume of supernatant and transfer water. According to the draft Privatization RFP, the Phase I HLW sludge is to be transferred into the private contractor feed/receipt tank(s) at a nominal $31 \mathrm{~g}$ oxides/L. This is equivalent to approximately $2.5 \mathrm{wt} \%$ insoluble solids.

Based on the draft RFP criteria, the range of total volume of water washed sludge plus the required amount of transfer water are shown in Table 4-3. As shown in the last row of Table 4-3, the estimated feed slurry volume can vary between 2,480 and $14,000 \mathrm{~m}^{3}$, depending on the weight percent of insoluble solids to be delivered to the private contractor. (The range specified in the draft RFP is 2.5 to $13 \mathrm{wt} \%$ solids). The weight percent of insoluble solids will depend upon the amount of sludge consolidated in 102-AZ, tank capacity, and physical and chemical properties of the sludge. Further dilution is possible through in-line mixing of the feed slurry with water. The slurry transfer volume impacts the number of batch transfers, the volume of the vendor feed receipt tank(s), and feed batch scheduling.

Table 4-3. Feed Slurry Ranges to Phase I High-Level Waste Vitrification (Base Case Consolidation Scenario).

\begin{tabular}{|c|c|c|c|c|}
\hline & \multicolumn{2}{|c|}{$\begin{array}{l}\text { Minimum sludge retrieval (base } \\
\text { case) }\end{array}$} & \multicolumn{2}{|c|}{ Maximum sludge retrieval } \\
\hline $\begin{array}{l}\text { Available mass of dilute caustic washed } \\
\text { solids }\end{array}$ & \multicolumn{2}{|c|}{$524,000 \mathrm{~kg}$} & \multicolumn{2}{|c|}{$826,000 \mathrm{~kg}$} \\
\hline $\begin{array}{l}\text { Available volume of dilute caustic } \\
\text { washed solids }\end{array}$ & \multicolumn{2}{|c|}{$328 \mathrm{~m}^{3}$} & \multicolumn{2}{|c|}{$516 \mathrm{~m}^{3}$} \\
\hline $\begin{array}{l}\text { Required mass of dilute caustic washed } \\
\text { solids }^{2}\end{array}$ & \multicolumn{2}{|c|}{$413,000 \mathrm{~kg}$} & \multicolumn{2}{|c|}{$442,000 \mathrm{~kg}$} \\
\hline $\begin{array}{l}\text { Required volume of dilute caustic } \\
\text { washed solids }{ }^{2}\end{array}$ & \multicolumn{2}{|c|}{$258 \mathrm{~m}^{3}$} & \multicolumn{2}{|c|}{$276 \mathrm{~m}^{3}$} \\
\hline \multirow{2}{*}{$\begin{array}{l}\text { Required slurry volume to Phase I } \\
\text { HLW vitrification feed tank(s) }\end{array}$} & 13 wt \% Solids & 2.5 wt\% Solids & 13 wt $\%$ Solids & $2.5 \mathrm{wt} \%$ Solids \\
\hline & $2,480 \mathrm{~m}^{3}$ & $13,000 \mathrm{~m}^{3}$ & $2,640 \mathrm{~m}^{3}$ & $14,000 \mathrm{~m}^{3}$ \\
\hline
\end{tabular}

HLW $=$ High-level waste

'This mass and volume represents the amount of sludge at the estimated composition (Appendix A) required to meet the draft RFP minimum specification of $190 \mathrm{MT}$ of waste oxides, excluding sodium and silicon.

"The 2.5 and $13 \mathrm{wt} \%$ solids cases assume $190 \mathrm{MT}$ of waste oxides, excluding sodium and silicon, and represent the slurry volume range to be sent to the Phase I HLW vitrification facility. 
The total tank volume of DST 102-AZ, which is approximately $3,790 \mathrm{~m}^{3}$, permits storage of an 8 to $10 \mathrm{wt} \%$ solids slurry ( $258 \mathrm{~m}^{3}$ of dilute caustic washed solids) based on consolidating all of the solids in 102-AZ. Assuming no additional dilution, transfer of this slurry directly to the vendor feed tank(s) will require 10 batches, assuming a vendor receipt tank capacity of $379 \mathrm{~m}^{3}$ (Chapter 5.0). Further dilution of the waste will require a larger receipt tank storage capacity or more batch transfers. For example, a $2.5 \mathrm{wt} \%$ slurry will require approximately 34 batches to transfer $13,000 \mathrm{~m}^{3}$ of slurry. For the base case, a preliminary schedule based on 10 batch transfers of a $10 \mathrm{wt} \%$ solids slurry is included in Chapter 5.0.

\subsection{MINIMUM QUANTITY OF PRETREATED FEED FOR PHASE I HIGH-LEVEL WASTE VITRITICATION}

A primary requirement for Phase I HLW is to provide a sufficient quantity of pretreated feed to the HLW demonstration facility. The available quantity of waste that can be delivered will assist in the design of the Phase I HLW melter, production capacity, scheduling of batch operations, and in the definition of lag storage, feed receipt, and feed staging requirements. The quantity of equivalent waste oxides will vary depending on the pretreatment strategy.

\subsubsection{Base Case Consolidation Scenario}

Assuming the base case consolidation scenario, the estimated consolidated inventories will meet the feed quantity specification. This study assumes a range of fractional recoveries from each of the source tanks (see Section 3.2). An estimated 241,000 to $355,000 \mathrm{~kg}$ of waste oxides (excluding sodium and silicon) are produced with dilute caustic washing (one dilute caustic wash to remove excess sodium), and between 187,000 and $279,000 \mathrm{~kg}$ with caustic washing plus one dilute caustic wash. See Tables C-1 and C-2 of Appendix C for a detailed comparison of waste oxide quantities from alternative pretreatment strategies. A comparison with the targeted range of feed oxides is summarized in Table 4-4 below.

Table 4-4. Estimated Phase I High-Level Waste Feed Oxide Quantity Ranges.

\begin{tabular}{|c|c|c|}
\hline & $\begin{array}{c}\text { Minimum quantity of waste } \\
\text { oxides produced }\end{array}$ & $\begin{array}{c}\text { Maximum quantity of waste } \\
\text { oxides produced }\end{array}$ \\
\hline Dilute caustic wash & $241,000 \mathrm{~kg}$ & $355,000 \mathrm{~kg}$ \\
\hline Caustic wash & $189,000 \mathrm{~kg}$ & $279,000 \mathrm{~kg}$ \\
\hline $\begin{array}{c}\text { Caustic wash 106-C, } \\
\text { dilute caustic wash AZ }\end{array}$ & $220,000 \mathrm{~kg}$ & $321,000 \mathrm{~kg}$ \\
\hline Targeted range & $190,000 \mathrm{~kg}$ & None \\
\hline
\end{tabular}


As shown in Table 4-4, based on the base case consolidation scenario, the minimum estimated quantity of Phase I waste oxides is above $190 \mathrm{MT}$. Caustic leaching may bring the waste oxides below the minimum, but the assumed caustic leach efficiencies may be over estimated (see Section 3.2.2.2). At this time, no specification has been made in the RFP (DOE 1995a) for the treatment of HLW above $190 \mathrm{MT}$. Waste quantities above the minimum that are available in tank $102-\mathrm{AZ}$ may provide an opportunity to extend the duration (or increase the production capacity) of the Phase I HLW demonstration facility if required.

The minimum quantities reported in Table 4-4 reflect the base case assumptions for Phase I consolidation (Bacon 1995). Further reductions in the consolidated sludge volume (assuming no modification to the RFP minimum quantity specification), or less consolidation, may require the identification of alternative feed sources and feed envelope specifications. The following section addresses the concept of "no consolidation" as an alternative bounding case.

\subsection{2 "No Consolidation" Case}

The minimum feed quantity specifications can be met if only 101-AZ and 102-AZ are used as source tanks and dilute caustic washing of these sludges is conducted. Table 4-1 contains the equivalent waste oxide quantities on an individual tank basis. If 99 percent of the two AZ tanks is recovered, approximately 190 MT can be provided to the Phase I HLW contractor feed tank(s).

Alternatively for the "no consolidation" case, 106-C sludge, after being combined and dilute caustic washed in 102-AY, will provide a sufficient amount of feed (approximately $190 \mathrm{MT}$ ). The "no consolidation" case assumes at least 75 percent of 106-C sludge will be retrieved into 102-AY. This alternative requires the installation of mixer pumps in 102-AY to accomplish the sludge mixing, pretreatment, and retrieval.

Although there is a potential for meeting the minimum feed quantity, the processing of the individual tanks in the "no consolidation" case may violate some ranges of the draft RFP HLW feed composition specifications (see Tables B-3 through B-6 in Appendix B), depending on the pretreatment strategy. A revision of the draft RFP is recommended. Section 4.3 discusses these impacts.

\subsection{PHASE I HIGH-LEVEL WASTE FEED ENVELOPE ASSESSMINT}

To provide feed for the Phase I HLW demonstration facility, the PHMC will deliver HLW sludge to the private contractor in batches via pipeline. The draft RFP provides preliminary requirements and assumptions concerning the HLW feed transfers. Specification 8 of the draft RFP, the High-Level Waste Feed Envelope Definition, provides 
minimum and maximum values for each major waste constituent and physical property. These specifications include waste chemicals, radionuclides, and physical properties of the feed slurry, and serve as the melter design basis for the HLW contractor. Tables B-1 through B-5 in Appendix B of this report summarize the feed composition estimates and compares them with the draft RFP feed composition requirements.

\subsubsection{Summary of Results}

The concentration ranges listed in Tables S8-1A, 1B, 2, and 3 (Specification 8) of the draft RFP are based on "an overall waste concentration of $31 \mathrm{~g}$ non-volatile oxides/L. Concentration values given in these tables will vary in direct proportion to the actual overall concentration of percent non-volatile oxides" (DOE 1995a). The non-volatile oxides include all of the elements listed in Table S8-1A. The Specification 8 tables and the recommended changes to Specification 8 are included in Appendix B.

4.3.1.1 Base Case Consolidation Scenario. Based on one dilute caustic wash, three minor waste constituents (shaded values in Tables B-1 through B-5 of Appendix B), are above the maximum draft RFP HLW feed envelope specifications. These components are summarized for the base case in Table 2-1.

Depending upon the pretreatment strategy, other components may fall outside of the specified composition ranges. Refer to Tables B-1 and B-2 in Appendix B for the details of the Feed Envelope Assessment as applied to the base case consolidation scenario. The comparisons in Table 2-1 are based on one dilute caustic wash of the consolidated sludges assuming the minimum retrieval case.

To resolve these discrepancies in the HLW feed envelope specifications, modifications to the RFP are recommended. A replacement of the RFP Specification 8 is included in Appendix B following the Feed Envelope Assessment. With the changes to the HLW feed specification described in Appendix B, all of the components of the consolidated sludge will fall within the feed composition limits.

4.3.1.2 "No Consolidation" Case. A summary of the Feed Envelope Assessment based upon the processing of individual tanks is shown in Table 4-5. 
Table 4-5. Comparison of Selected Waste Constituents with the Draft Request for Proposals Feed Envelope for High-Level Waste ("No Consolidation").

\begin{tabular}{|c|c|c|c|c|c|}
\hline Source tank & $\begin{array}{c}\text { Aluminum } \\
(\mathrm{g} / \mathrm{L})\end{array}$ & $\begin{array}{c}\text { Selenium } \\
(\mathrm{g} / \mathrm{L})\end{array}$ & $\begin{array}{c}\text { Silver } \\
(\mathrm{g} / \mathrm{L})\end{array}$ & $\begin{array}{c}\text { Tellurium } \\
(\mathrm{g} / \mathrm{L})\end{array}$ & $\begin{array}{c}\text { Thallium } \\
(\mathrm{g} / \mathrm{L})\end{array}$ \\
\hline $106-\mathrm{C} / 102-\mathrm{AY}$ & 2.66 & -- & 0.10 (high) & -- & \\
\hline $101-\mathrm{AZ}$ & $\begin{array}{c}3.41 \\
\text { (high) }\end{array}$ & $\begin{array}{c}0.12 \\
(\text { high) }\end{array}$ & -- & 0.13 (high) & 0.44 (high) \\
\hline $102-\mathrm{AZ}$ & 3.16 & 0.06 & -- & 0.02 & 0.00323 \\
\hline $\begin{array}{c}\text { Draft RFP } \\
\text { maximum }\end{array}$ & 3.30 & 0.12 & 0.10 & 0.06 & 0.08 \\
\hline $\begin{array}{c}\text { Revised } \\
\text { maximum }\end{array}$ & 5.3 & 0.16 & 0.17 & 0.04 & 0.16 \\
\hline
\end{tabular}

RFP $=$ Request for Proposals

The concentrations shown above are the calculated maximums taken from Tables B-3 through B-5, considering the preferred pretreatment strategy (i.e., dilute caustic or caustic washing, multiple washes, etc.) for the individual tank. The HLW feed specifications will be modified for the final RFP so that the concentrations will fall within the feed envelope for individual tanks (except for tellurium and thallium). Appendix B discusses these changes. The high thallium and tellurium values shown for 101-AZ result from relatively high "less than detection linit" reported core sample analyses. These have been incorporated into the inventory databases as actual measured values. Evaluation of expected feed composition based on fission yields indicated all feeds will be within the design range.

4.3.1.3 "Mobilize 102-AY Solids" Case. The HLW feed composition is estimated based upon the assumption that 36 percent of the 102-AY solids are mobilized in the transfer of 106-C to 101-AZ. This recovery fraction is based on the installation of two 300-hp mixer pumps (Grams 1995). The sludge recoveries from the other source tanks are consistent with those listed in Table 3-1. Table 4-6 summarizes the results of the Feed Envelope Assessment for this case (also see Appendix B).

The mobilization of a fraction of 102-AY solids has a minimal impact of the Phase I HLW feed composition, as shown in Table 4-6. As in the base case consolidation scenario, the concentrations which exceed the maximums of the draft RFP will fall within the revised RFP maximums. Therefore, if the additional $13,300 \mathrm{~kg}$ of waste oxides (excluding sodium and silicon) is desired or incidentally recovered, a satisfactory feed can be provided. 
Table 4-6. Comparison of Selected Waste Constituents with the Draft Request for Proposals Feed Envelope for High-Level Waste ("Mobilize 102-AY Solids").

\begin{tabular}{|c|c|c|c|c|}
\hline Component & $\begin{array}{c}\text { Minimum } \\
\text { concentration } \\
(\mathrm{g} / \mathrm{L})\end{array}$ & $\begin{array}{c}\text { Estimated } \\
\text { concentration } \\
(\mathrm{g} / \mathrm{L})\end{array}$ & $\begin{array}{c}\text { Maximum } \\
\text { concentration } \\
(\mathrm{g} / \mathrm{L})\end{array}$ & $\begin{array}{c}\text { Revised } \\
\text { maximum } \\
\text { concentration } \\
(\mathrm{g} / \mathrm{L})\end{array}$ \\
\hline Aluminum & 1.00 & 2.96 & 3.30 & 5.30 \\
\hline Chromium & 0.04 & 0.08 & 0.25 & 0.42 \\
\hline Iodine & 0.00 & 0.0000291 (high) & 0.0000014 & 0.001 \\
\hline Iron & 3.30 & 5.46 & 8.90 & 13 \\
\hline Phosphorus & 0.01 & 0.14 & 0.19 & 0.54 \\
\hline Sodium & 3.00 & 5.37 & 6.00 & 9.2 \\
\hline Thallium & 0.00 & $0.09($ high) & 0.083 & 0.14 \\
\hline Zirconium & 0.02 & 0.86 & 2.80 & 4.6 \\
\hline${ }^{14} \mathrm{C}$ & 0.00 & $0.00000205 \mathrm{Ci} / \mathrm{L}$ & $0.000001 \mathrm{Ci} / \mathrm{L}$ & $0.000002 \mathrm{Ci} / \mathrm{L}$ \\
\hline
\end{tabular}

\subsubsection{Recommendations and Conclusions}

Assuming the appropriate changes are made to Specification 8 of the Privatization RFP, the range of estimated waste compositions will fall within the feed specifications, except for the 101-AZ individual feed thallium and tellurium values. The changes indicated in Appendix B should be made for the final RFP.

\subsection{IMPACT OF ALTERNATIVE PRETREATMENT STRATEGIES ON FIGH-LEVEL WASTE VOLUMES}

Sludge washing is conducted for the base case as described in Bacon (1995). The recovered fraction of 106-C is washed in 101-AZ, and the combined AZ farm sludges are washed in 102-AZ. After washing, the contents of 101-AZ are transferred to 102-AZ. This consolidated, washed sludge is then available for transfer to the private contractor's facility.

The different methods of pretreating the waste may have an impact on the volume of HLW generated. In this analysis, it is estimated that no reduction in the amount of HLW glass produced in Phase I occurs as a result of caustic washing followed by one dilute caustic wash. Using the low-temperature CVS glass composition region (Hrma et al. 1994) as a basis, the HLW glass is limited by $\mathrm{Fe}_{2} \mathrm{O}_{3}(15 \mathrm{wt} \%)$ after one dilute caustic wash to remove 
residual sodium. The effect of caustic washing is to caustic leach a fraction of the aluminum and chromium, and metathesize phosphate from the solids. Table 3-3 in Chapter 3.0 lists the assumed caustic leach efficiencies. If the waste oxide loading is limited by the maximum wt $\%$ of $\mathrm{Fe}_{2} \mathrm{O}_{3}$, further reductions in the total amount of glass are not incurred through caustic leaching. The results are summarized in Table 4-7.

Table 4-7. Percent Reduction in Reference High-Level Waste Glass from Caustic Leaching.

\begin{tabular}{|l|c|c|}
\hline & $\begin{array}{c}\text { Volume of } \\
\text { high-level waste } \\
\left.\text { glass ( } \mathrm{m}^{3}\right)\end{array}$ & $\begin{array}{c}\text { Number of } \\
\text { reference }\left(0.62-\mathrm{m}^{3}\right. \\
\text { capacity) high-level } \\
\text { waste canisters }\end{array}$ \\
\hline $\begin{array}{l}\text { Water wash (1 dilute caustic }[0.1 M] \\
\text { wash) }\end{array}$ & 248 to 333 & 400 to 537 \\
\hline $\begin{array}{l}\text { Enhanced Sludge Wash (3.0M) (1 caustic } \\
\text { wash followed by 1 dilute caustic wash) }\end{array}$ & 248 to 309 & 400 to 499 \\
\hline Volume reduction & $0 \%$ to $7 \%$ & $0 \%$ to $7 \%$ \\
\hline
\end{tabular}

The results of this analysis indicate that for the reference case, caustic leaching does not significantly reduce the Phase I HLW glass volumes. However, due to uncertainties in waste compositions, chemical solubilities, and actual glass composition limits based on properties, there may be benefits to conducting caustic washing. It is recommended the systems be put into place for caustic washing, which may be beneficial for the technology demonstration alone. The following section discusses that the benefit depends on the tank waste composition and the glass formulation.

\subsection{RELATIONSHIPS BETWEEN PRETREATMINT AND THE HIGH-LEVEL WASTE GLASS FORMULATION}

In Phase I, the reference HLW product specification is a borosilicate glass in a $0.61-\mathrm{m}$ diameter by $3.05-\mathrm{m}$ high stainless steel container with a nominal capacity of $0.62-\mathrm{m}^{3}$ of glass. The type of melter and the glass formulation are not specified in the draft RFP.

As a part of this evaluation, two alternative formulations for low-temperature borosilicate glasses are included in Table C-11 of Appendix C. The differences between the glass formulation in the current baseline flowsheet case (Orme 1995), which is the HWVP (Kalia 1994) glass formulation, and the CVS glass composition region can significantly affect the quantity of HLW glass generated during Phase I. The flexibility to use alternative glass formulations will depend upon the type of melter selected and several other factors. 
WHC-SD-WM-ES-370

Revision 0

\subsubsection{Alternative High-Level Waste Glass Formulations}

The results of alternative glass formulations are shown in Table 4-8.

Table 4-8. Effect of Alternative High-Level Waste Glass Formulations.

\begin{tabular}{|l|c|c|c|}
\hline \multicolumn{1}{|c|}{ Melter type } & $\begin{array}{c}\text { Volume of high- } \\
\text { level waste } \\
\text { glass }\left(\mathrm{m}^{3}\right)\end{array}$ & $\begin{array}{c}\text { Number of } \\
0.63-\mathrm{m} \text { OD x 3.05-m } \\
\text { canisters }\end{array}$ & $\begin{array}{c}\text { Reduction } \\
\text { from } \\
\text { flowsheet } \\
\text { glass } \\
\text { formulation }\end{array}$ \\
\hline $\begin{array}{l}\text { Flowsheet Glass Formulation } \\
\left(1150^{\circ} \mathrm{C}\right) \text { (Orme 1995) }\end{array}$ & 333 & 537 & -- \\
\hline $\begin{array}{l}\text { Composition Variation Study } \\
\left.\text { Glass Limits (1150 }{ }^{\circ} \mathrm{C}\right) \\
\text { (Hrma et al. 1994) }\end{array}$ & 248 & 400 & $26 \%$ \\
\hline $\begin{array}{l}\text { Potential Phase I Glass } \\
\text { Formulation (Appendix D) }\end{array}$ & 230 & 374 & $30 \%$ \\
\hline
\end{tabular}

${ }^{a}$ These values are based on the output of glass property models developed by Pacific Northwest National Laboratory.

The values in Table 4-8 should only be used to represent a range for glass volumes produced by a low-temperature melter. The actual volumes will depend on the specific type of melter applied. The range presented here is an indicator that the glass formulation is a significant factor in the generation of HLW glass. When changing from the flowsheet glass formulation to the CVS glass formulation, for example, the number of reference canisters is reduced from 537 to 400 , or 26 percent. This reduction is due primarily to the an increase in the iron oxide loading limit of $12 \mathrm{wt} \%$ to $15 \mathrm{wt} \%$ in the HLW glass.

If a high-temperature melter is employed, an even greater reduction may be expected for this waste composition (assuming that $\mathrm{Fe}_{2} \mathrm{O}_{3}$ can be higher than $15 \mathrm{wt} \%$ in the glass product). The oxide component that reaches its limit and the impact of glass formulation are influenced by the specific composition of the waste.

\subsubsection{Alternative Pretreatment Strategies}

The glass formulation will impact the choice of a pretreatment strategy. Or, conversely, the pretreatment strategy may have some impact on the "choice" of a glass formulation. Based on the flowsheet glass limits (Orme 1995) and conducting one dilute caustic wash of the sludges to remove excess sodium, the glass is limited by the combined component constraint for $\mathrm{Al}_{2} \mathrm{O}_{3}, \mathrm{Fe}_{2} \mathrm{O}_{3}$, and $\mathrm{ZrO}_{2}$. Removing aluminum by caustic leaching will remove $\mathrm{Al}_{2} \mathrm{O}_{3}$ in the glass, the glass will reach its $\mathrm{Fe}_{2} \mathrm{O}_{3}$ limit, and the glass volume 
cannot be reduced any further. The overall reduction in the number of canisters is 7 percent because the $\mathrm{Fe}_{2} \mathrm{O}_{3}$ is close to the $12 \mathrm{wt} \%$ limit at the $\mathrm{Al}_{2} \mathrm{O}_{3}+\mathrm{Fe}_{2} \mathrm{O}_{3}+\mathrm{ZrO}_{2}$ limit. However, it also has been shown, by statistical analysis, that multi-component constraints should not be used for estimating the limiting components(s) of glass (Hrma et al. 1994, pages 11.49 through 11.56). If the multi-component constraints are omitted for the HWVP case, the caustic wash results in Tables 4-7 and 4-9 would be the same as those for the dilute caustic wash.

Based on the CVS limits (Hrma et al. 1994), one dilute caustic wash in addition to the retrieval dissolution of these sludges will be sufficient for the glass to reach the $15 \mathrm{wt} \%$ $\mathrm{Fe}_{2} \mathrm{O}_{3}$ limit. Caustic leaching of sludges has no benefit in this case. This demonstrates that waste which is vitrified using this alternative glass formulation, results in a glass that is not limited by aluminum, chromium, or phosphorus oxides, and does not require caustic leaching. These results are shown in Table 4-9.

Table 4-9. Effect of Alternative High-Level Waste Glass Formulations and Pretreatment Strategies.

\begin{tabular}{|c|c|c|c|}
\hline & \multicolumn{3}{|c|}{ Glass formulation limits } \\
\cline { 2 - 4 } & $\begin{array}{c}\text { Flowsheet basis } \\
\text { (Orme 1995) }\end{array}$ & $\begin{array}{c}\text { Composition } \\
\text { Variation Study } \\
\text { (Hrma et al. } \\
1994)\end{array}$ & $\begin{array}{c}\text { Potential Phase I } \\
\text { glass } \\
\text { formulation } \\
\text { (Appendix D) }\end{array}$ \\
\hline $\begin{array}{c}\text { Dilute caustic wash blend } \\
\text { Oxide loading, }^{\mathrm{b}} \mathrm{c}\end{array}$ & $27 \%$ & $36 \%$ & $39 \%$ \\
Number of canisters & 537 & 400 & 374 \\
\hline Caustic wash blend, b, d & & & \\
Oxide loading, & $23 \%$ & $29 \%$ & $31 \%$ \\
Number of canisters $^{\mathrm{b}}$ & 499 & 400 & 374 \\
\hline
\end{tabular}

${ }^{2}$ Assumes one additional dilute caustic wash to remove residual supernate sodium 'Non-volatile oxides not including sodium and silicon

${ }^{\mathrm{C}} \mathrm{Al}_{2} \mathrm{O}_{3}+\mathrm{Fe}_{2} \mathrm{O}_{3}+\mathrm{ZrO}_{2}$ limited for the flowsheet basis (Orme 1995), $\mathrm{Fe}_{2} \mathrm{O}_{3}$ limited for the CVS basis (Hrma et al. 1994)

${ }^{\mathrm{d} C a u s t i c}$ Wash of 106-C, 101-AZ, and 102-AZ

${ }^{\circ} \mathrm{Fe}_{2} \mathrm{O}_{3}$ Limited for flowsheet and CVS glass formulations.

Also, the waste oxide loading is $23 \mathrm{wt} \%$ and will fall slightly below the draft RFP specified minimum of $25 \mathrm{wt} \%$ waste oxides in glass excluding sodium and silicon (DOE 1995a) by caustic leaching the feed to the HLW melter using the flowsheet glass formulation. However, for the flowsheet glass formulation, caustic leaching may be necessary to reduce the amount of glass generated. The $25 \mathrm{wt} \%$ oxide limit may forbid certain pretreatment options. Caustic washing may be needed in Phase I HLW pretreatment 
WHC-SD-WM-ES-370

Revision 0

to provide a technology demonstration. It is recommended that the specification for a minimum loading of $25 \mathrm{wt} \%$ waste oxides be reviewed, since it may be contrary to the goal to minimize the HLW glass volume.

Multiple dilute caustic washes is a method for reducing the amount of sodium going to $\mathrm{HLW}$ vitrification. The maximum quantity of $\mathrm{Na}_{2} \mathrm{O}$ in the glass is limited to $12.5 \mathrm{wt} \%$ in the flowsheet (HWVP) low-temperature melter and $20 \mathrm{wt} \%$ using the CVS glass formulation. For waste streams with a relatively large amount of sodium in the supernate, and those which reach the $\mathrm{Na}_{2} \mathrm{O}$ upper bound in the glass as a result, it is beneficial to wash the sludge multiple times with dilute caustic.

Table 4-10 summarizes the effect of multiple dilute caustic washes for the base case (flowsheet glass formulation).

Table 4-10. Impact of the Number of Washes in the Pretreatment of Phase I High-Level Waste (Composition Variation Study Glass Limits).

\begin{tabular}{|c|c|c|}
\hline Total number of washes & $\begin{array}{c}\text { Number of } \\
0.61-\mathrm{m} \text { OD } \times 3.05-\mathrm{m} \\
\text { high-level waste } \\
\text { canisters }\end{array}$ & $\begin{array}{c}\text { Overall reduction versus } \\
\text { no washes }\end{array}$ \\
\hline 0 & 679 & Not applicable \\
\hline 1 & 400 & $41 \%$ \\
\hline 2 & 400 & $41 \%$ \\
\hline 3 & 400 & $41 \%$ \\
\hline 4 & 400 & $41 \%$ \\
\hline
\end{tabular}

In the in-tank sludge washing process, dilute caustic is added to the waste to reach an $8 \mathrm{wt} \%$ solids slurry. It is allowed to settle to $20 \mathrm{wt} \%$ solids, and the supernate is decanted. This is the sludge washing efficiency assumed for the calculations in Table 4-10, and is consistent with the TWRS Process Flowsheet (Orme 1995). This analysis shows that one dilute caustic wash is necessary to remove sodium from the NCAW and high-heat sludges. Varying the number of washes in the pretreatment process will allow the attainment of the minimum number of HLW canisters, depending on the glass formulation and feed specification limits. The results for each of the cases discussed above are illustrated in Figures 4-1 through 4-4. 
Figure 4-1. Impact of Attemative Phase I HLW Pretreatment Strategies

(Low Temperature CVS Glass Composition) - Minimum Retrieval Case
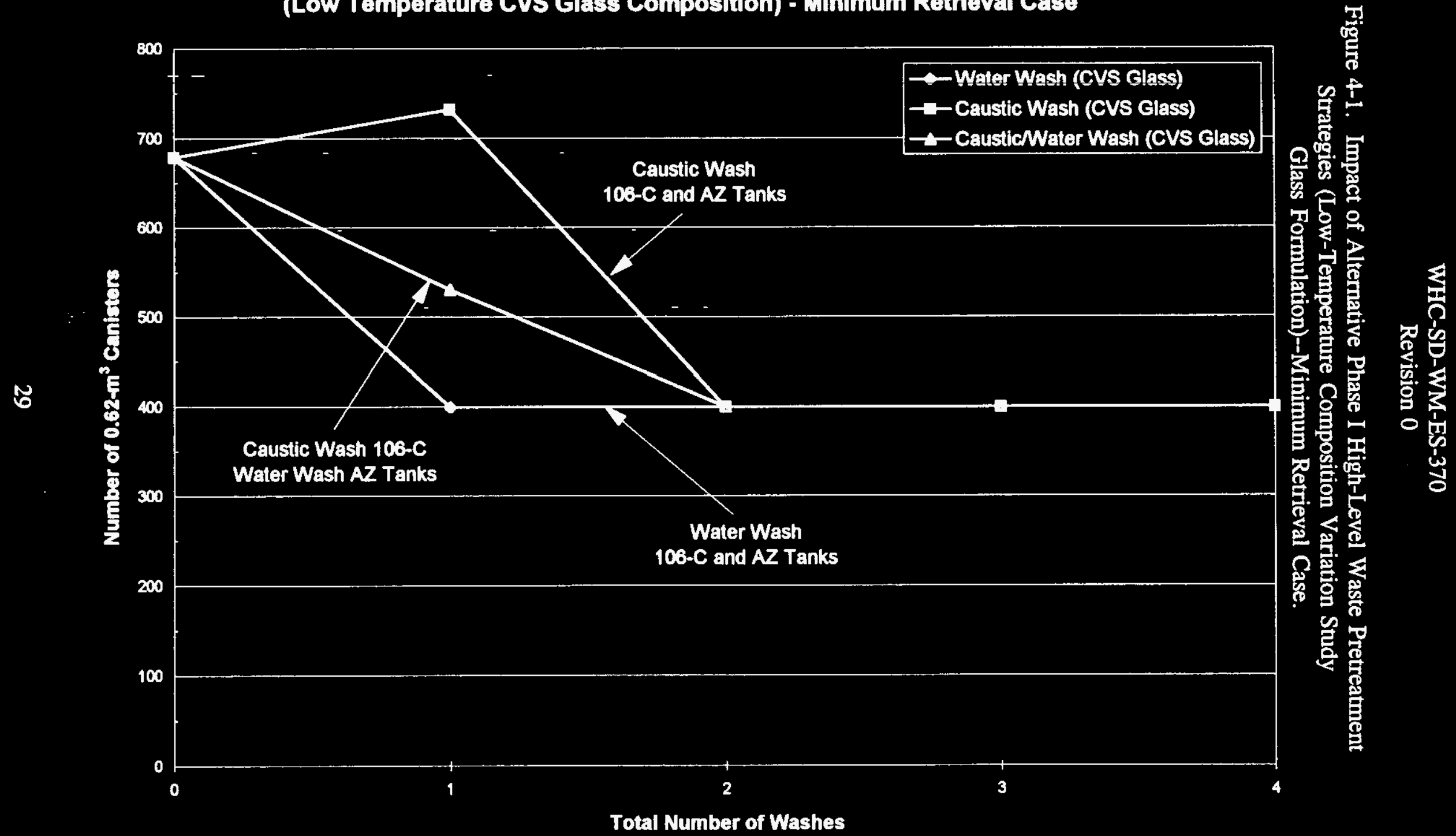
Figure 4-2. Impact of Altemative Phase I HLW Pretreatment Strategies

(Low Temperature HWV Glass Formulation) - Minimum Retrieval Case
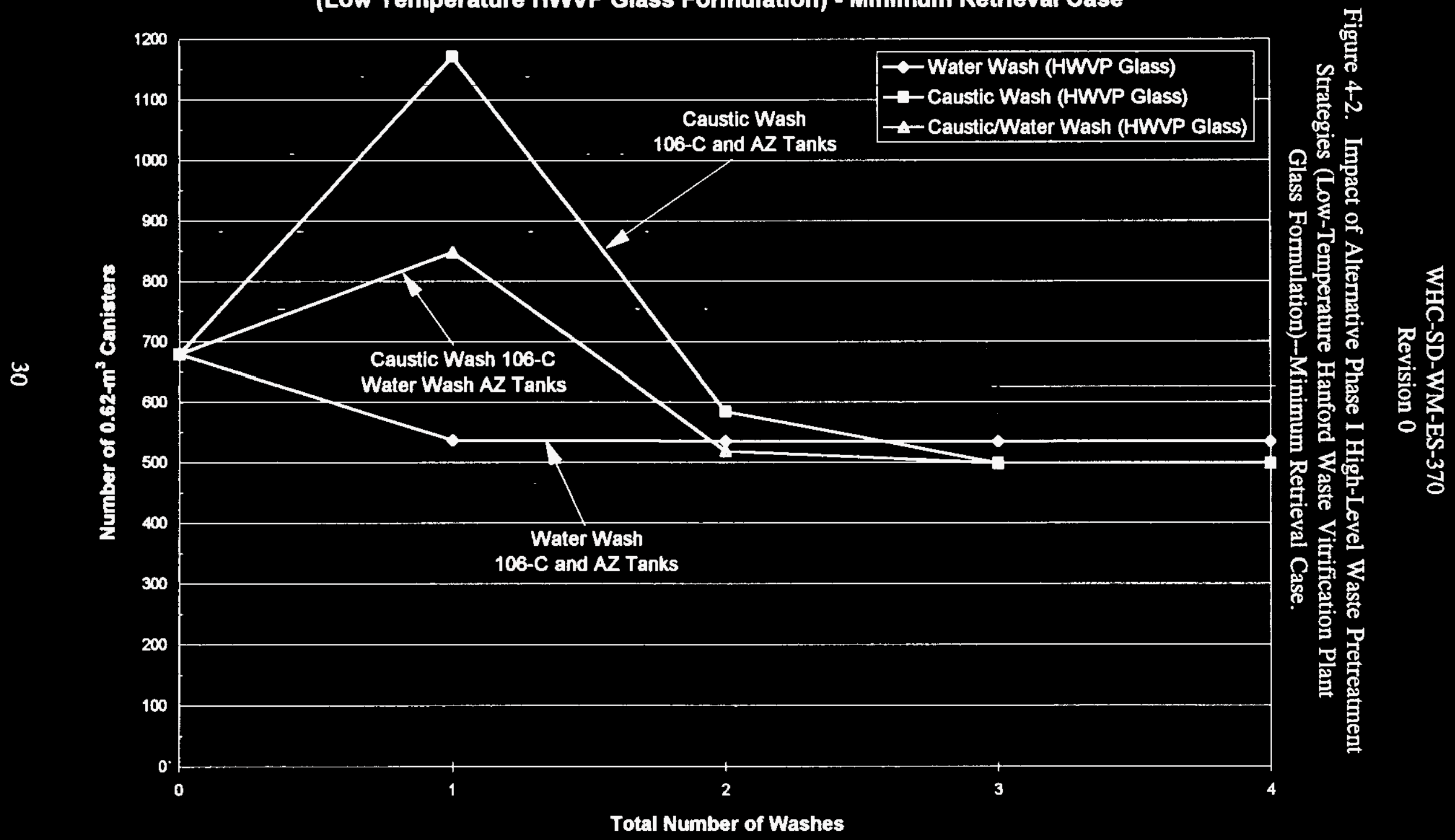
Figure 4-3. Impact of Alternative Phase I High-Level Waste Pretreatment Strategies (Low-Temperature Composition Variation Study Glass Formulation)--Maximum Retrieval Case.

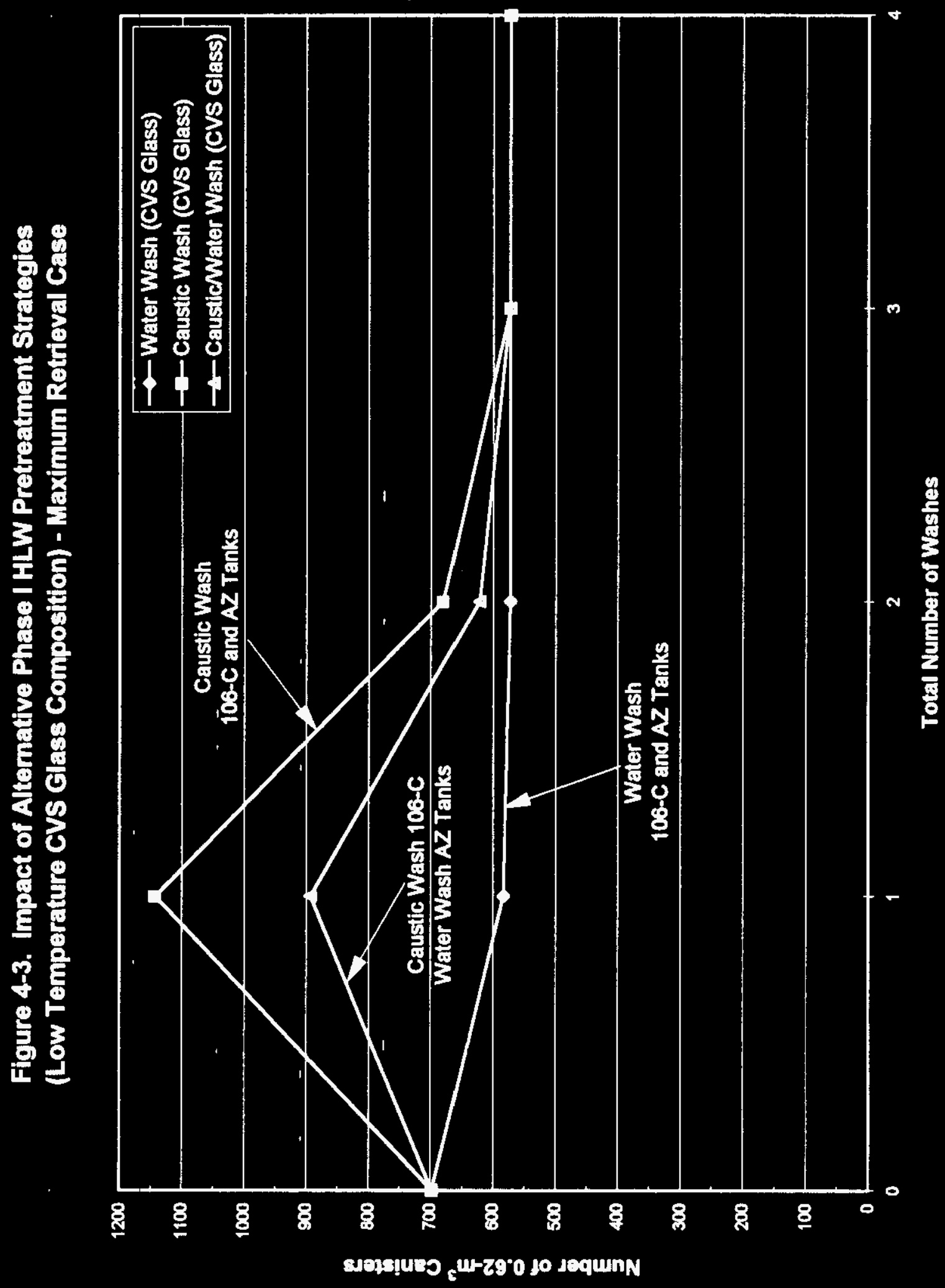


Figure 4-4. Impact of Alternative Phase I High-Level Waste Pretreatment Strategies (Low-Temperature Hanford Waste Vitrification Plant Glass Formulation)--Maximum Retrieval Case.

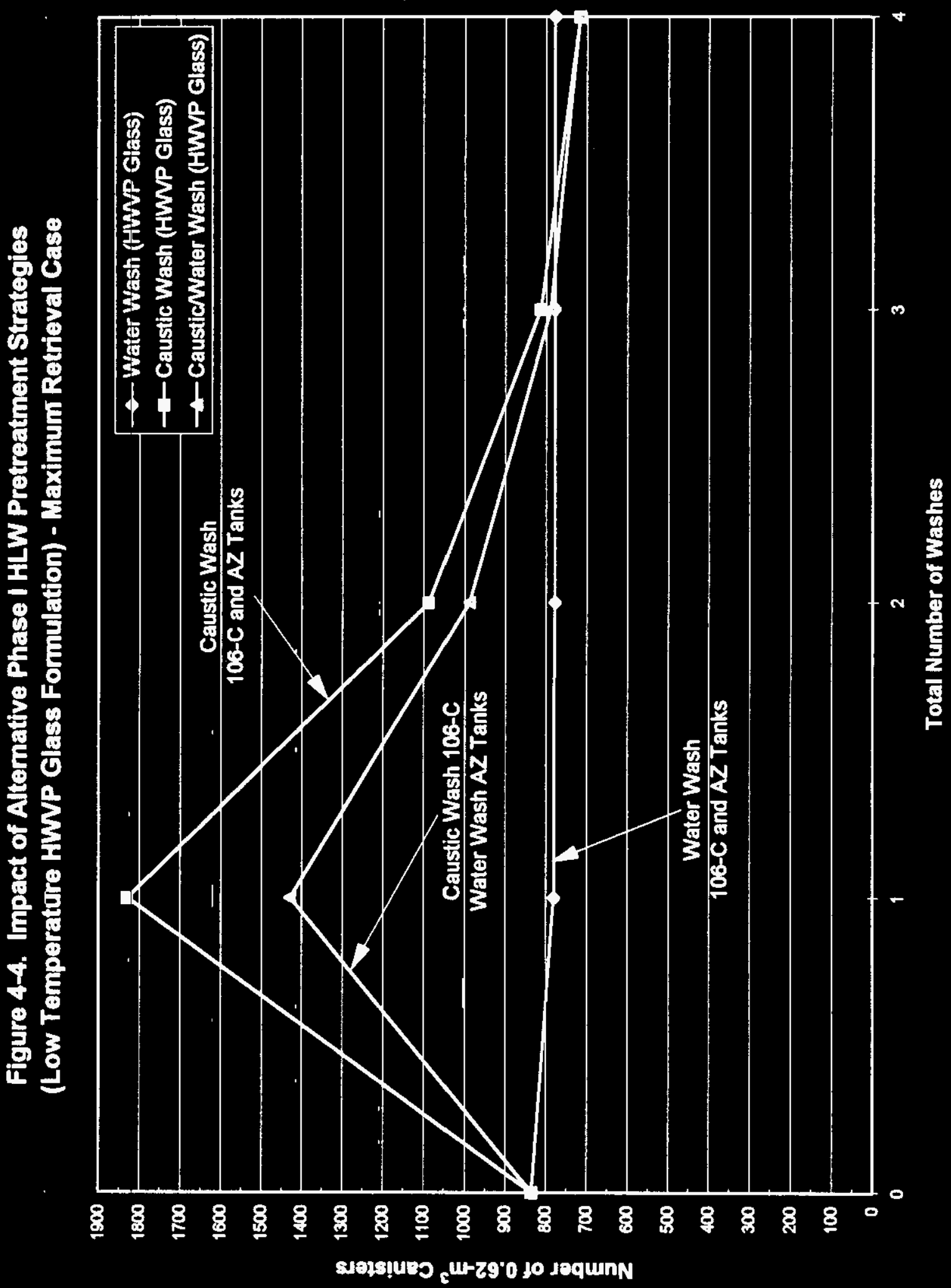


WHC-SD-WM-ES-370

Revision 0

\subsection{RECOMMENDATIONS AND CONCLUSIONS}

This evaluation of the Phase I HLW pretreatment strategy shows the impacts and demonstrates the sensitivities of several process parameters. The detailed results of these cases are included in the appendixes. The major parameters examined and which have not been established are as follows:

- NCAW Consolidation (Including "No Consolidation")

- HLW Glass Formulation

- In-Tank Sludge Washing

^ DST Storage Impacts.

A base case strategy is recommended in this analysis. However, as decisions are made regarding these parameters, modifications will be made and incorporated into the August 1996 update of the Phase I HLW Pretreatment and Feed Staging Plan.

\subsubsection{Neutralized Current Acid Waste Consolidation}

A decision has yet to be made with regard to the extent to which the Phase I HLW sludges are consolidated. The NCAW Consolidation Management Plan (Powell 1996), outlines several alternative consolidation scenarios for NCAW sludges. The HLW

Pretreatment and Feed Staging Plan considers the uncertainty in the preferred case by evaluating a range of fractional recoveries of the sludge and the impacts of "no consolidation." Once a plan has been established for consolidation, the appropriate modifications will be made, and will be incorporated into the August 1996 update of this HLW feed staging plan.

\subsubsection{High-Level Waste Glass Formulation}

This parameter is one which can not be established for Privatization. However, it is an important one to consider in terms of a range (Section 4.5) when preparing a feed to the private contractor. This document considers a range of alternative low-temperature glass formulations to indicate if there are potential sensitivities to the pretreatment process. Testing with simulants and potential glass formulations by Pacific Northwest National Laboratory (PNNL) currently is being conducted (Appendix D). This preliminary analysis suggests that there is a relatively small sensitivity between pretreatment and the glass formulation based on a $15 \mathrm{wt} \% \mathrm{Fe}_{2} \mathrm{O}_{3}$ limit. However, based on several uncertainties, including waste compositions and solubility behavior, recovery fractions, consolidation, and the glass formulation itself, the relationships and sensitivities between the pretreatment strategy and possible glass formulations should be considered for planning purposes for HLW pretreatment and feed staging in Phase I Privatization. 


\subsubsection{Dilute Caustic Washing Versus Caustic Leaching}

Dilute caustic washing is recommended. This preliminary analysis suggests a 0 to 7 percent reduction in HLW glass volumes resulting from caustic leaching of the Phase I sludges. No reduction is predicted with the CVS glass limits (Hrma et al. 1994) and testing by PNNL (Appendix D). A reduction in canisters is expected using the HWVP limits (Kalia 1994). However, without the multi-component limits, no reduction is predicted. As stated above, process and inventory uncertainties may lead to a different conclusion. For example, with a higher aluminum to iron ratio in the waste, the $\mathrm{HLW}$ glass may approach the $\mathrm{Al}_{2} \mathrm{O}_{3}$ limit, in which case caustic leaching might have a significant benefit to glass volume reduction.

Other benefits such as obtaining process information must also be considered as discussed in Section 2.0. Therefore, the placement of systems in preparation for the possibility of caustic leaching in Phase I HLW processing is recommended. A detailed evaluation, such as the Operational Waste Volume Projection (OWVP) (Koreski and Strode 1995), also is recommended to determine the DST storage impacts (Section 4.6.5). The tradeoffs between glass volume reduction and DST storage depletion are presented in Tables 4-11 and 4-12.

\subsubsection{In-Tank Sludge Washing}

The number of washes recommended in this analysis is one dilute caustic wash, in addition to retrieval. This is based on the washing procedure described in Section 4.5.2. Alternative assumptions for the solids settling and washing in the in-tank sludge washing process, rather than an $8 \mathrm{wt} \%$ solids dilution and a $20 \mathrm{wt} \%$ solids settling efficiency, may result in a different number of washes. For example, a reduction in the amount of dilute caustic added to the sludge, so that the result is greater than $8 \mathrm{wt} \%$ solids, may increase the number of washes required. The net result of this modification to the process may be a smaller total volume of wash solution to achieve the same extent of removal. This sensitivity is dependent upon the settling characteristics of the Phase I sludges and DST storage volume impacts, and will be examined in a future revision of this document.

\subsubsection{Low-Level Waste Feed Volume Impacts}

As discussed in Section 3.2.2, large additions of wash solutions in the Phase I pretreatment strategy may deplete a limited amount of DST storage space. In Appendix A, Tables A-5 through A-14 show the changes in HLW and LLW chemical and radionuclide concentrations in each AZ tank as the tanks are washed, based on dilute caustic and caustic washing. The ILLW volume impacts for these cases are summarized in Tables 4-11 and 4-12. 
WHC-SD-WM-ES-370

Revision 0

Table 4-11. Low-Level Waste Volume Impacts of the Phase I High-Level Waste Pretreatment Strategy (Dilute Caustic Washing).

\begin{tabular}{|c|c|c|c|c|c|}
\hline Number of washes & None & 1 & 2 & 3 & 4 \\
\hline LLW Volume $\left(\mathrm{m}^{3}\right)^{\mathrm{a}}$ & 457 & 688 & 812 & 908 & 995 \\
\hline $\begin{array}{c}\text { HLW Sludge Volume } \\
\left(\mathrm{m}^{3}\right)\end{array}$ & 327 & 326 & 324 & 323 & 323 \\
\hline $\begin{array}{c}\text { HLW Sludge Volume } \\
\text { Reduction }\end{array}$ & N/A & $0.3 \%$ & $0.6 \%$ & $0.3 \%$ & $0.0 \%$ \\
\hline HLW Glass Volume (m $\left.{ }^{3}\right)$ & 420 & 250 & 250 & 250 & 250 \\
\hline $\begin{array}{c}\text { Waste Oxide Loading } \\
\text { Excluding Sodium and } \\
\text { Silicon }\end{array}$ & $21 \%$ & $36 \%$ & $36 \%$ & $36 \%$ & $36 \%$ \\
\hline
\end{tabular}

HLW $=$ : High-level waste

LLW $=$ Low-level waste

${ }^{a}$ Concentrated to the $7 M \mathrm{Na}$ Limit.

Table 4-12. Low-Level Waste Volume Impacts of the Phase I High-Level Waste Pretreatment Strategy (Caustic Leaching).

\begin{tabular}{|c|c|c|c|c|c|}
\hline Number of washes & None & $\begin{array}{c}1 \text { (caustic } \\
\text { leach) }\end{array}$ & 2 & 3 & 4 \\
\hline LLW Volume $\left(\mathrm{m}^{3}\right)^{\mathrm{a}}$ & 457 & 3,230 & 3,870 & 4,090 & 4,210 \\
\hline $\begin{array}{c}\text { HLW Sludge Volume } \\
\left(\mathrm{m}^{3}\right)\end{array}$ & 327 & 278 & 277 & 276 & 275 \\
\hline $\begin{array}{c}\text { HLW Sludge Volume } \\
\text { Reduction }\end{array}$ & N/A & $15.0 \%$ & $0.4 \%$ & $0.4 \%$ & $0.4 \%$ \\
\hline $\begin{array}{c}\text { HLW Glass Volume } \\
\left.\text { (m }{ }^{3}\right)\end{array}$ & 420 & 460 & 250 & 250 & 250 \\
\hline $\begin{array}{c}\text { Waste Oxide Loading } \\
\text { Excluding Sodium and } \\
\text { Silicon }\end{array}$ & $21 \%$ & $16 \%$ & $29 \%$ & $28 \%$ & $28 \%$ \\
\hline
\end{tabular}

HLW $=$ High-level waste

LLW $=$ Low-level waste

${ }^{a}$ Concentrated to the $7 M \mathrm{Na}$ Limit. 
Caustic washing of the Phase I sludges will result in $3,870 \mathrm{~m}^{3}$ of LLW versus $688 \mathrm{~m}^{3}$ with only dilute caustic washing. These volumes are based on the Bacon 1995 consolidation scenario with the minimum retrieval fractions. The calculations indicate for this preliminary evaluation that the LLW wash solutions will consume approximately one DST, if the sludges are caustic leached and washed once more with dilute caustic. Significantly less space is required with only one dilute caustic wash, which is the recommended pretreatment strategy in this analysis. However, if there is a significant cost benefit to a "potential" reduction in glass volumes (e.g., an increase in waste oxide loading leading to a 30 percent decrease in glass volume), this must be traded against the estimated increase in the volume of LLW supernates/wash solutions shown in Tables 4-11 and 4-12.

Potential destinations for these LLW streams will be assessed as part of the next revision of the OWVP (Koreski and Strode 1995). The results of the revised OWVP and the interfaces with Phase I LLW feed staging will be integrated into the August 1996 revision of this document. One dilute caustic wash is the preferred pretreatment strategy in this analysis, because it minimizes HLW glass volumes and LLW supernates. The August 1996 update of this document will include the results of future evaluations. 
WHC-SD-WM-ES-370

Revision 0

\subsection{PRELIMINARY FEED STAGING STRATEGY AND ARCHITECTURE}

Eight alternative HLW transfer routes were evaluated for the transfer of washed HLW solids from tank 241-AZ-102 to the Phase I HLW treatment private contractor. Alternatives evaluated consisted of using the existing, regulatory compliant underground transfer lines to the maximum extent practical. Table 5-1 presents a comparison of each alternative.

Based upon this preliminary evaluation, Alternative 8 is recommended as the proposed method for transfer of the washed solids to the private contractor's HLW processing facility. Alternative 8 utilizes a new underground pipeline in conjunction with existing underground pipelines as the transfer route from tank AZ-102 to the private contractor's facility. The optional use of a dedicated DST in AP tank farm as a HLW feed staging/receipt tank was evaluated, but is not recommended. This sub-option to Alternative 8 would require the installation of a mixer pump and transfer pump pit within the designated AP Farm DST to ensure the washed HLW solids could be suspended and transferred to the private contractor's facility. Since the mixer pump and transfer pump proposed for installation in tank AZ-102 will have the capability to transfer washed HLW solids to the private contractor's facility, the costs to modify a DST in AP Tank Farm do not seem warranted. If a DST is required, the DST storage implications of using a tank in AP farm will be assessed by the next release of the Operational Waste Volume Projection (Koreski and Strode 1995). These results will be incorporated in the August 1996 update of this document.

Alternative 1 is recommended as a contingency method for transfer of the washed HLW solids to the private contractor. The Alternative 1 transfer route may incur interferences with operation of the 242-A Evaporator and require the installation of a booster pump to transfer washed HLW solids to the private contractor. As such, this alternative is less favorable than Alternative 8.

Further evaluation of Alternative 1 and 8 transfer routes is required to confirm system design, address safety and environmental issues (e.g., 242-A Evaporator Safety Analysis Report and compliance of cleanout boxes for secondary containment), and refine a cost estimate. Additional evaluation needs to be performed to assess transfer scheduling for all tank farm activities (e.g., SST Saltwell pumping, 242-A Evaporator operation LLW feed transfers) that will be supported during the HLW transfer period. This effort will support identification of new jumpers to be fabricated to provide maximum transfer flexibility and minimize process pit entries for routing changes. 
WHC-SD-WM-ES-370

\section{Revision 0}

Table 5-1. High-Level Waste Demonstration Alternatives.

\begin{tabular}{|c|c|c|c|c|c|c|c|c|c|}
\hline \multirow{2}{*}{ Alternative } & \multirow{2}{*}{ Destingtion } & \multirow{2}{*}{$\begin{array}{l}\text { Toonl } \\
\text { head } \\
\text { loss }\end{array}$} & \multirow{2}{*}{$\begin{array}{c}\text { Total } \\
\text { pressure } \\
\text { drop }\end{array}$} & \multirow{2}{*}{$\begin{array}{l}\text { Lowest } \\
\text { design } \\
\text { pressure }\end{array}$} & \multicolumn{2}{|c|}{ Velocity $(\pi / s)$} & \multirow{2}{*}{$\mathrm{L} / \mathrm{min}$} & \multirow{2}{*}{$\begin{array}{c}\text { Total pipe } \\
\text { length } \\
\text { to } A P\end{array}$} & \multirow{2}{*}{ Disadvantages } \\
\hline & & & & & 2-in. & 3-in. & & & \\
\hline \multirow[b]{2}{*}{ Alternative 1} & AP-107 & $136 \mathrm{~m}$ & $1.9 \mathrm{MPa}$ & \multirow[b]{2}{*}{$2.6 \mathrm{MPa}$} & \multirow[b]{2}{*}{1.9} & \multirow[b]{2}{*}{ NA } & \multirow[b]{2}{*}{4.1} & \multirow[b]{2}{*}{$952 \mathrm{~m}$} & \multirow{2}{*}{$\begin{array}{l}\text { - Interferes with } \\
242-A \\
\text { Evaporator } \\
\text { operation }\end{array}$} \\
\hline & $\begin{array}{l}\text { Private } \\
\text { contractor's } \\
\text { situ }\end{array}$ & $191 \mathrm{~m}$ & $2.6 \mathrm{MPa}$ & & & & & & \\
\hline \multirow[b]{2}{*}{ Alternative 2} & AP-107 & $138 \mathrm{~m}$ & $1.9 \mathrm{MPa}$ & \multirow[t]{2}{*}{$2.6 \mathrm{MPa}$} & \multirow[b]{2}{*}{1.9} & \multirow[b]{2}{*}{ NA } & \multirow[b]{2}{*}{4.1} & \multirow[b]{2}{*}{$954 \mathrm{~m}$} & \multirow{2}{*}{$\begin{array}{l}\text { - Interferes with } \\
242-A \\
\text { Evaporator } \\
\text { operation }\end{array}$} \\
\hline & $\begin{array}{l}\text { Private } \\
\text { contractor's } \\
\text { sit: }\end{array}$ & $193 \mathrm{~m}$ & $2.6 \mathrm{MPa}$ & & & & & & \\
\hline \multirow[b]{2}{*}{ Alternative 3} & AP-107 & $165 \mathrm{~m}$ & $2.3 \mathrm{MPa}$ & \multirow{2}{*}{$1.6 \mathrm{MPa}$} & \multirow{2}{*}{4.0} & \multirow[b]{2}{*}{1.9} & \multirow[b]{2}{*}{8.8} & \multirow[b]{2}{*}{$908 \mathrm{~m}$} & \multirow{2}{*}{$\begin{array}{l}\text { - Pressure } \\
\text { problems with } \\
\text { existing lines } \\
\text { - Requires } \\
\text { booster pump }\end{array}$} \\
\hline & $\begin{array}{c}\text { Private } \\
\text { contractor's } \\
\text { site: }\end{array}$ & $195 \mathrm{~m}$ & $2.7 \mathrm{MPa}$ & & & & & & \\
\hline \multirow[b]{2}{*}{ Alternative 4} & AP-107 & $165 \mathrm{~m}$ & $2.3 \mathrm{MPa}$ & \multirow[b]{2}{*}{$1.6 \mathrm{MPa}$} & \multirow[b]{2}{*}{4.0} & \multirow[b]{2}{*}{1.9} & \multirow[b]{2}{*}{8.8} & \multirow[b]{2}{*}{$903 \mathrm{~m}$} & - Pressure \\
\hline & $\begin{array}{l}\text { Private } \\
\text { contractor's } \\
\text { sitt: }\end{array}$ & $195 \mathrm{~m}$ & $2.7 \mathrm{MPa}$ & & & & & & $\begin{array}{l}\text { existing lines } \\
\text { - Requires } \\
\text { booster pump }\end{array}$ \\
\hline Alternative 5 & $\begin{array}{l}\text { Private } \\
\text { contractor's } \\
\text { sit: }\end{array}$ & $\cdot 183 \mathrm{~m}$ & $2.5 \mathrm{MPa}$ & $1.6 \mathrm{MPa}$ & 4.0 & 1.9 & 8.8 & $758 \mathrm{~m}$ & $\begin{array}{l}\text { - Pressure } \\
\text { problems with } \\
\text { existing lines }\end{array}$ \\
\hline & $\begin{array}{c}\text { New Valve } \\
\text { Pit }\end{array}$ & $149 \mathrm{~m}$ & $2.1 \mathrm{MPa}$ & & & & & & valve pit \\
\hline & AP-107 & $409 \mathrm{~m}$ & $5.6 \mathrm{MPa}$ & & & & & & - Unacceptable \\
\hline Alternative 6 & $\begin{array}{c}\text { Private } \\
\text { contractor's } \\
\text { sitt: }\end{array}$ & $635 \mathrm{~m}$ & $8.8 \mathrm{MPa}$ & $1.6 \mathrm{MPa}$ & 4.0 & 1.9 & 8.8 & $920 \mathrm{~m}$ & 2 -in. lines \\
\hline Alternative 7 & $\begin{array}{c}\text { Private } \\
\text { contractor's } \\
\text { sit: }\end{array}$ & $131 \mathrm{~m}$ & $1.8 \mathrm{MPa}$ & New Line & NA & 1.9 & 8.8 & $\begin{array}{c}1,818 \mathrm{~m} \\
\text { (to private } \\
\text { contractor) }\end{array}$ & $\begin{array}{l}\text { - Requires new } \\
\text { line } \\
\text { ( }-\$ 10 \text { million) }\end{array}$ \\
\hline & AP-107 & $92 \mathrm{~m}$ & $1.3 \mathrm{MPa}$ & & & & & & Requires new \\
\hline Alternative 8 & $\begin{array}{l}\text { Privite } \\
\text { contractor's } \\
\text { situ: }\end{array}$ & $122 \mathrm{~m}$ & $1.7 \mathrm{MPa}$ & $1.6 \mathrm{MPa}$ & NA & 1.9 & 8.8 & $912 \mathrm{~m}$ & $\begin{array}{c}\text { line } \\
\text { ( } \$ \text { S1 million) }\end{array}$ \\
\hline
\end{tabular}

Viscosity $=10 \mathrm{cp}$

Specific Gravity $=1.4$

Prototype Pump Design $=136 \mathrm{~m}$ at $8.8 \mathrm{~L} / \mathrm{min} ; 158 \mathrm{~m}$ a $4.1 \mathrm{~L} / \mathrm{min}$. 
WHC-SD-WM-ES-370

Revision 0

\subsection{CRITERIA FOR EVALUATION OF HIGH-LEVEL WASTE TRANSFER ALTERNATIVES}

For the Phase I HLW demonstration, the washed solids consolidated in the DST 241-AZ-102 are to be transferred into the private contractor's HLW process facility feed/receipt tank(s) or into an existing DST designated as a contractor feed/receipt tank; e.g., 241-AP-107. Transfers of the retrieved waste are to be accomplished through compliant pipe-in-pipe underground lines and associated process pits that provide adequate radiological shielding and waste containment. Eight alternative feed staging strategies are evaluated as part of this study.

The following waste transfer criteria for the alternatives are being evaluated:

1. Minimize interference with the operation of the 242-A Evaporator; this would be accomplished by not transferring waste through $241-\mathrm{AW}-\mathrm{B}$ valve pit.

2. Use transfer route that is made up of 2-in. or 3-in. lines for the entire route. This will eliminate velocity transitions that can cause solids to settle out during the transfer.

3. Once a transition from a 2-in. to a 3-in. line has occurred, the transfer will continue in the 3-in. line system until the waste has reached its destination. This goal may require that a booster pump be placed into the system to assure that the minimum waste transfer velocity is maintained.

4. Provide a routing that minimize head loss, pressure drop, minimize process pits to be transferred through, and minimize the need to upgrade the existing A Farm Complex transfer system; i.e., adding booster pumps, new jumpers, new transfer lines, etc.

5. Selected waste transfer routing shall provide reliable feed delivery to the private contractor by minimizing down time for routing set-up.

\subsection{ASSUMPTIONS}

To evaluate each of the alternatives, the following assumptions are made:

1. Only pipe-in-pipe transfer lines will be used to transfer waste to the private contractor. This assumption supports the stated goal of DOE-RL and WHC not to use pipe in concrete encasements.

2. HLW could be interim staged in the 241-AP-107 Tank. If this assumption is implemented the tank will either be limited in waste volume due to the heat load of the waste, or the ventilation system will have to be upgraded to handle 
the increased heat load. Additionally, the tank will have to be upgraded with a mixer pump system and new transfer pump pit.

3. Alternatives 5 and 7 assume that the waste will be transferred directly to the private contractor and staged in the processing plant.

4. The transfer lines terminate at a location east of AP Tank Farm within the site allocated for use by the private contractors (N40500 and W45500).

5. The elevation of the transfer piping at the private contractor's site location is $203 \mathrm{~m}$.

An alternate option to AP-107 being used as a feed staging/receipt tank is to transfer the waste directly to the private contractor's facility. This option would require jumpers to be installed in the tank pump transfer pit and would not allow waste to enter the tank.

Alternatives 5 and 7 assumes that the waste will be transferred directly to the private contractor and staged in the HLW processing plant, with no connection to the AP Tank Farm. The in-plant tank size would need to be between 190 to $379 \mathrm{~m}^{3}$ based on operational experience for efficient waste transfers in the tank farms.

\subsection{EXISTING SYSTEM DESCRIPTION}

The existing waste transfer system for the A Farm Complex (200 East DSTs) consists of underground transfer lines, valve pits, diversion boxes, sluice pits, and pump pits. Portions of the waste transfer systems date back to construction of the single shell tanks in 241-A and 241-AX Tank Farms. The waste transfer system also includes newer waste transfer components built to support the 242-A Evaporator, AN, AW, AY and AZ DSTs. Figure 5-1 depicts the A Farm Complex pipe-in-pipe waste transfer system as it exists today. Appendix E, Table E-1 provides a listing of the process pits and associated line destinations.

The transfer lines consist of slurry lines; designated as SL; and supernate lines; designated as SN. The slurry lines have a nominal 2 -in. diameter. The supernate lines have a nominal 3-in. diameter. An exception exists in the waste transfer routes between AN Tank Farm to AZ Tank Farm and from AZ Tank Farm to the 241-AX-A and B valve pits; all transfer lines either SN or SL are nominal 2-in. diameter. 
WHC-SD-WM-ES-370

\section{Revision 0}

Figure 5-1. A Farm Complex. (Sheet 1 of 2)
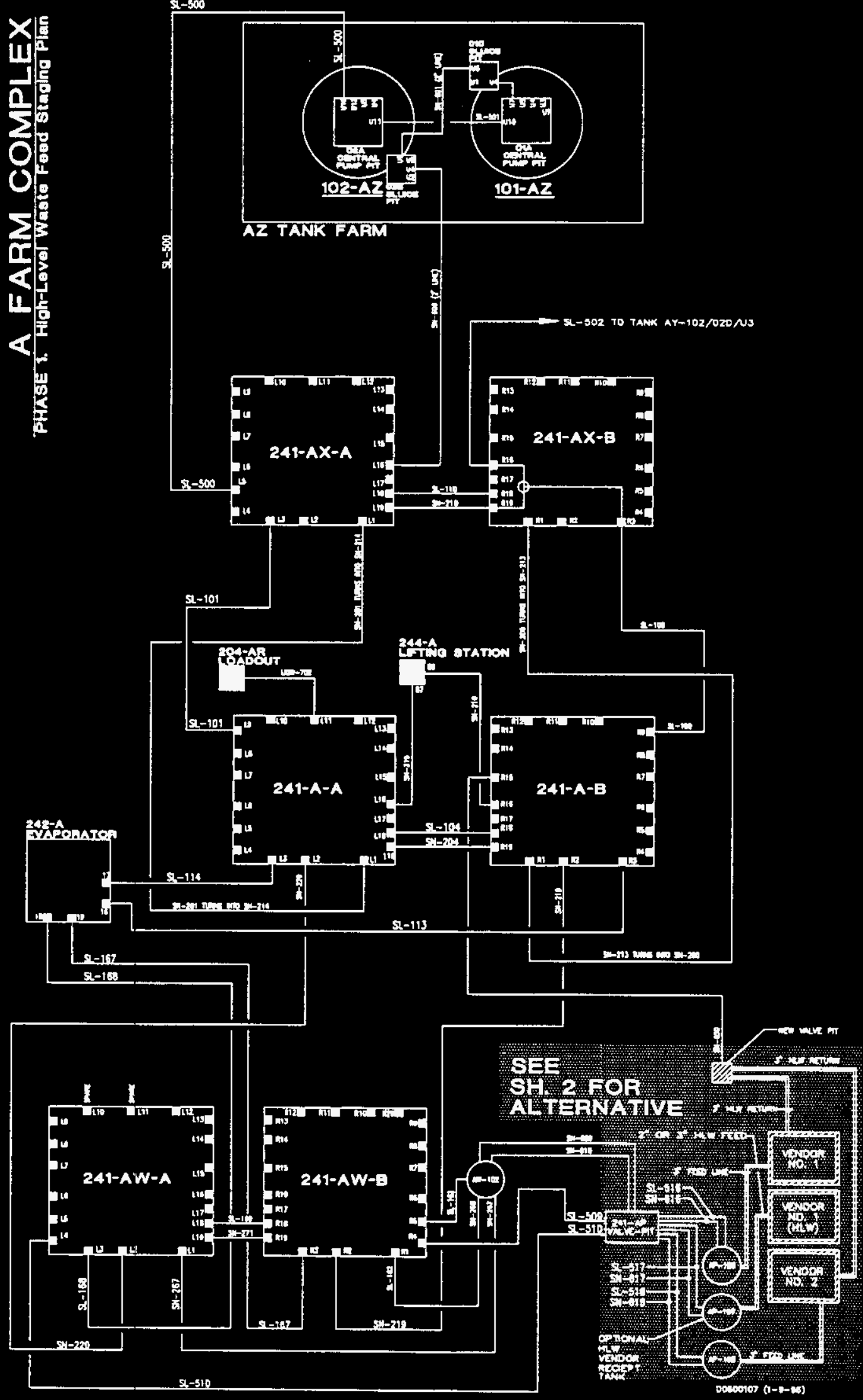
WHC-SD-WM-ES-370

Revision 0

Figure 5-1. A Farm Complex. (Sheet 2 of 2)

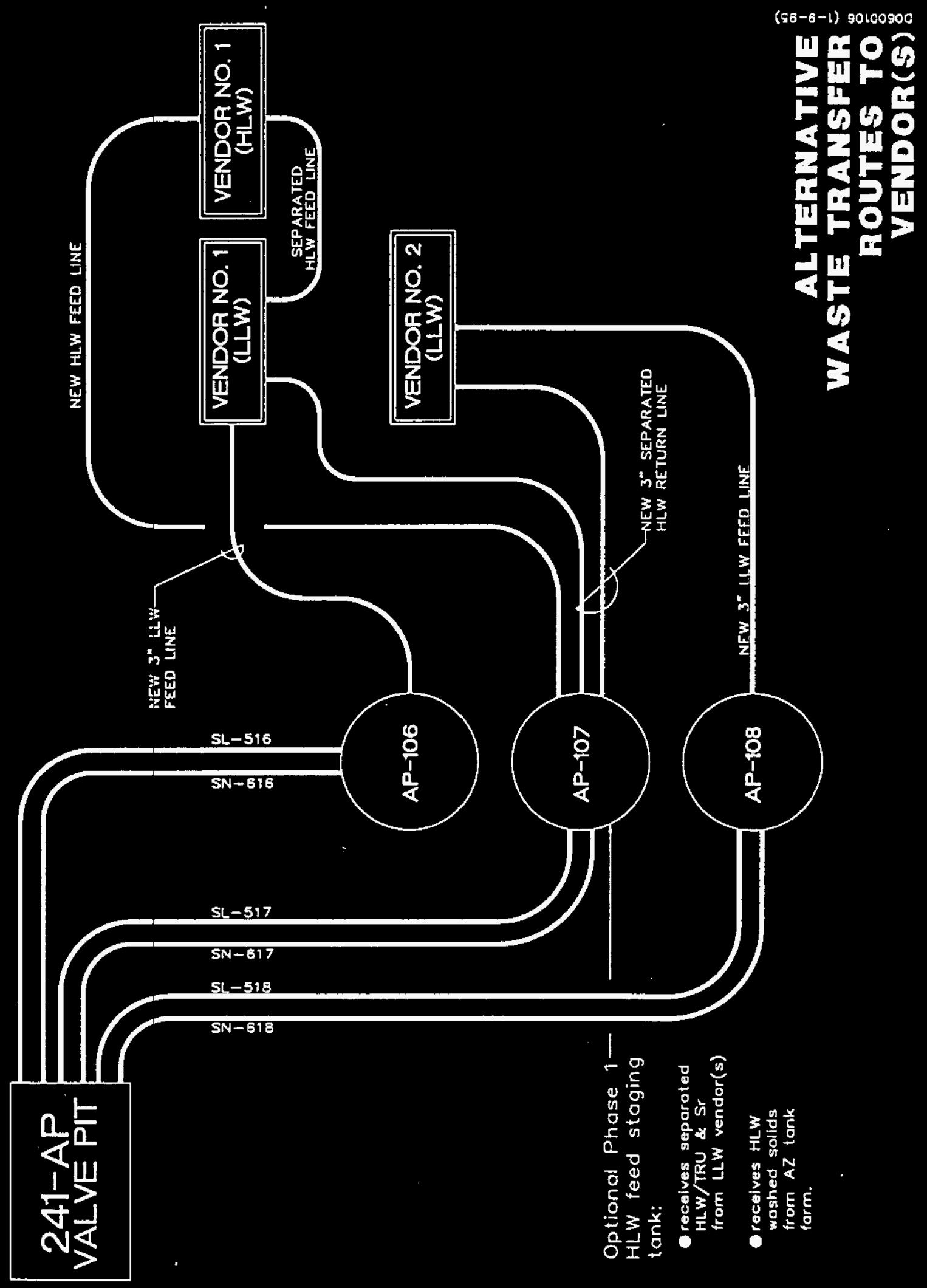




\section{WHC-SD-WM-ES-370 \\ Revision 0}

The diversion boxes, valve pits, sluice pits, and/or pump pits consist of below grade reinforced concrete structures that house nozzles connected to waste transfer lines. The concrete structures painted with a special protective coating aids in sealing the concrete surface and aids in the decontamination of the pits in the event that process solution is leaked into the pit. Various routes are set up by connecting jumpers; remotely installed piping assemblies with process equipment such as valves, flow meters, etc.; in the pits to designated nozzles.

\subsection{OPTIONS FOR THE PHASE I FEDD TO THE HIGH-LIEVEL WASTE PROCESS FACILITY}

Two options exist for transferring feed to the HLW process facility. The first option consists of transferring feed from tank 102-AZ to a designated feed staging/receipt tank in the 241-AP Tank Farm, i.e., AP-107, and from this tank to process facility. The second option consists of transferring feed from tank 102-AZ directly to the HLW process facility. This transfer may either be accomplished by providing a dedicated route, use existing routes and by-pass the AP tank farm, or by routing the waste to the private contractor's LLW AP feed staging/receipt tank.

\subsubsection{Feed from 241-AP Tank Farm}

This alternative allows for relatively short transfers from the designated 241-AP tank feed/receipt tank to the HLW process facility. The size of the receiving tank in the process facility could then be sized as a day tank to support the vitrification process.

This alternative has two sub-options. The first sub-option consists of transferring the feed to a DOE owned and operated feed tank in the 241-AP Tank Farm. The second suboption consists of transferring the feed to a privatized feed tank in the AP Tank Farm, this is currently assumed to be one of three tanks, AP-106, AP-107, or AP-108.

The tanks in 241-AP Tank Farm have a 70,000 Btw/h heat generation limit on them from all sources. This limit prevents the possibility of an unusual occurrence in the tank from heat gradients (e.g., tank roll over). To increase the tank heat generation limit, either the DOE or the privatization contractor can install new ventilation and/or in-tank equipment; i.e., agitation/mixer system; to increase the heat load handling capability.

\subsubsection{Feed from Tank 241-AZ-102}

This operational task requires a relatively long transfer from the AZ-102 feed tank to the HLW process facility. The length of the transfer line increases the size of the receiving tank in the process facility to accommodate the transfer volume and flush solutions. 


\section{Revision 0}

\subsection{ALTERNATIVES FOR TRANSFER ROUTES}

Eight potential alternatives for the waste transfer routes from tank AZ-102 to the privatization contractor have been identified. Six alternatives provide routes to transfer feed from AZ-102 to a designated feed receipt tank in the 241-AP Tank Farm. Two alternatives provide a waste transfer route from tank AZ-102 to the HLW process facility.

\subsubsection{Alternative 1 Transfer Route}

Alternative 1 makes use of existing 2-in. waste transfer lines. The waste transfer originates at the 241-AZ-02A central pump pit and passes through valve pits located in the 241-AX, 241-A, and 241-AW Tank Farms. This alternative requires jumper change outs in the 242-A Evaporator pump room to maintain the use of SL transfer lines to the AP Tank Farm. Additionally it is assumed that the 242-A evaporator would not be processing waste during the transfer of waste to the private contractor's designated feed/receipt tank located in the AP Tank Farm; i.e., AP-107. The private contractor would install a waste transfer line from AP-107 to the HLW processing facility.

An alternate route would be to transfer (by-pass the LLW feed staging/receipt tank) via a jumper in the transfer pump pit to the HLW processing facility. This sub-option is not considered to be favorable due to the head loss of the transfer (refer to Table 5-1).

Table 5-2 provides a detailed listing of the transfer lines and waste transfer pits and facilities that will be used by this alternative. Rigid jumpers will have to be fabricated to support establishing this waste transfer route. It is assumed at this time that the fabrication and installation of the required jumpers will be the responsibility of DOE and the PHMC. Currently it is anticipated the five to seven new jumpers will have to be fabricated at an estimated cost of $\$ 25,000$ each.

The transfer line from the designated AP tank will be the responsibility of the privatization contractor. It is also assumed that any modifications to the designated AP tank will be the responsibility of the privatization contractor. Modifications would, at a minimum, consist of installing a mixer pump system and a new transfer pump pit with a new transfer pump. 
WHC-SD-WM-ES-370

Revision 0

Table 5-2. Transfer Routing for Alternative 1.

\begin{tabular}{|l|c|l|}
\hline \multicolumn{1}{|c|}{ From process pit } & \multicolumn{1}{|c|}{ Transfer line } & \multicolumn{1}{|c|}{ To process pit } \\
\hline AZ-102/02A Pump Pit Nozzle U10 & 2-in. SL-500 & $\begin{array}{l}\text { 241-AX-A Valve Pit } \\
\text { Nozzle L5 }\end{array}$ \\
\hline 241-AX-A Valve Pit Nozzle L3 & 2-in. SL-101 & $\begin{array}{l}\text { 241-A-A Valve Pit } \\
\text { Nozzle L9 }\end{array}$ \\
\hline 241-A-A Valve Pit Nozzle L3 & 2-in. SL-114 & $\begin{array}{l}\text { 242-A Evaporator } \\
\text { Nozzle 17 }\end{array}$ \\
\hline 242-A Evaporator & 2-in. SL-168 & $\begin{array}{l}\text { 241-AW-A Valve Pit } \\
\text { Nozzle L3 }\end{array}$ \\
\hline Nozzle 18 & & $\begin{array}{l}\text { 241-AP Valve Pit } \\
\text { Nozzle 2 }\end{array}$ \\
Nozzle LW-A & 2-in. SL-510 & $\begin{array}{l}\text { Tank Central Pump Pit } \\
\text { AP-106/06A Nozzle B } \\
\text { AP-108/08A Nozzle B } \\
\text { 241-AP Valve Pit }\end{array}$ \\
$\begin{array}{l}\text { Nozzle 8/AP-106 } \\
\text { Nozzle 7/AP-108 }\end{array}$ & 2-in. SL-516 \\
Nozzle 6/AP-107 & 2-in. SL-518 SL-517 & \\
\hline
\end{tabular}

The total head loss for Alternative 1 is $136 \mathrm{~m}$ or $1.8 \mathrm{MPa}$ to the $241-\mathrm{AP}-107$ tank and $191 \mathrm{~m}$ or $2.6 \mathrm{MPa}$ to the private contractor's site. For this alternative there are no transitions to 3 -in. lines and, therefore, a flow rate of $4.3 \mathrm{~L} / \mathrm{min}$ will maintain the minimum required velocity to avoid line pluggage.

For transfers to the 241-AP-107 tank, the only upgrade to the existing A Farm Complex transfer system would be new jumpers in the process pits and the 242-A Pump Room. In addition, the pressure required to pump to this location is within the design pressure of the transfer lines utilized. However, this transfer routing would interfere with the operation of the 242-A Evaporator. Jumper change outs in the Evaporator Pump Room would be required if an Evaporator campaign was to be done. Additionally the 242-A Safety Analysis would have to be evaluated to resolve safety issues associated with increasing the Cs concentration of the waste.

Additional upgrades are required to the A Farm Complex if Alternative 1 is used to transfer waste directly to the private contractor. A booster pump would be required in AP Tank Farm and the design pressures of pipelines SL-101 and SL-114 may need to be increased. However, the increase in design pressure for these lines is limited due to the use of cleanout boxes in the SL routings and further analysis would be required.

Figure 5-2 shows the transfer routes for alternatives one and two. 
WHC-SD-WM-ES-370

\section{Revision 0}

Figure 5-2. Transfer Routes for Alternatives 1 and 2.
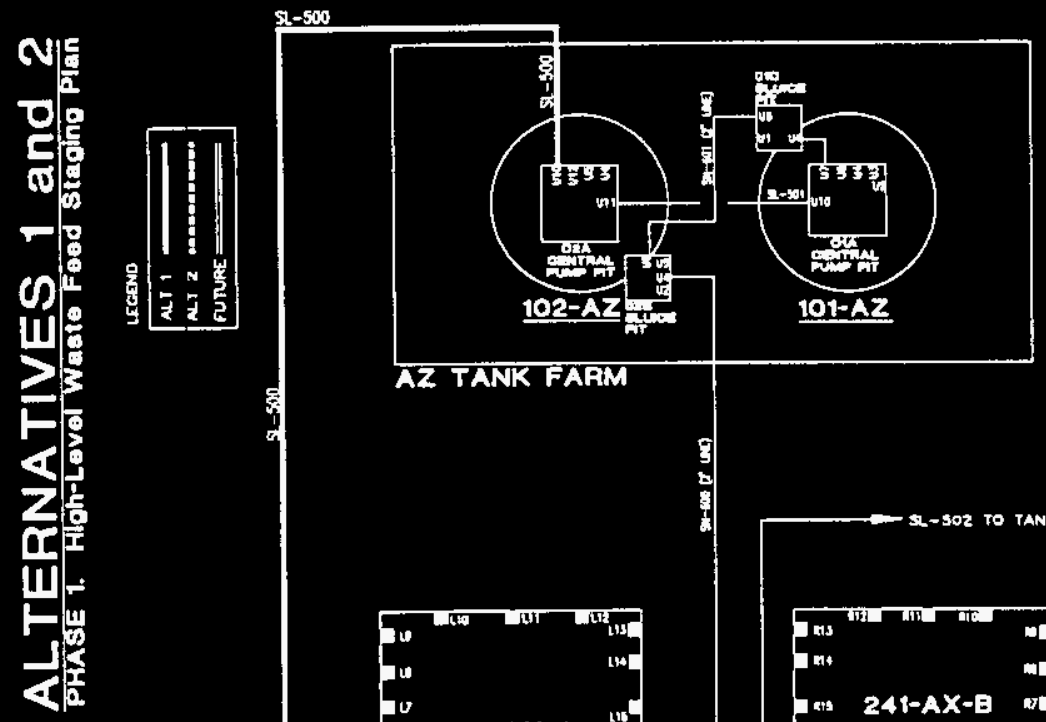

III

竞:

氙表至
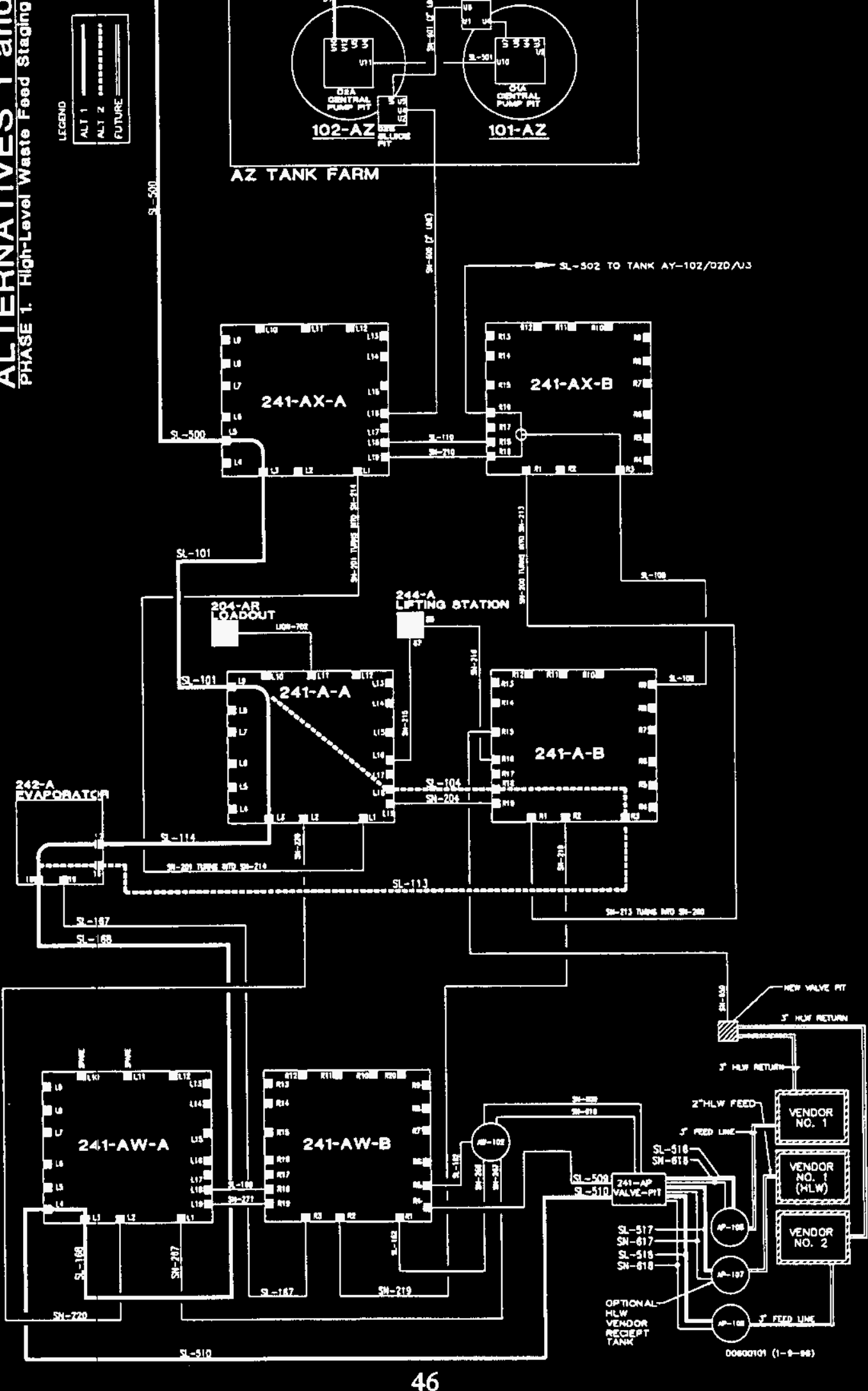
WHC-SD-WM-ES-370

Revision 0

\subsubsection{Alternative 2 Transfer Route}

Alternative 2 is similar to alternative one with the exception that the alternate route goes through the 241-A-B valve pit.

Table 5-3 provides a detailed listing of the transfer lines and waste transfer pits and facilities that will be used by this alternative. Rigid jumpers will have to be fabricated to support establishing this waste transfer route, the quantity of jumpers required is the same as Alternative 1. Figure 5-2 shows this transfer alternative by the use of dotted lines for the alternate routing configuration between $241-\mathrm{A}-\mathrm{A}$ to $241-\mathrm{A}-\mathrm{B}$ valve pits, and then from the 241-A-B valve pits to 242-A Evaporator.

The total head loss for alternative two is $138 \mathrm{~m}$ or $1.9 \mathrm{MPa}$ to the $241-\mathrm{AP}-107$ tank and $193 \mathrm{~m}$ or $2.7 \mathrm{MPa}$ to the private contractor's site.

The advantages and disadvantages are the same as for Alternative 1. However, Alternative 2 requires the use of one more waste transfer line and process pit with the additional possibility of new jumpers.

Table 5-3. Transfer Route for Alternative 2.

\begin{tabular}{|c|c|c|}
\hline From process pit & Transfer line & To process pit \\
\hline $\begin{array}{l}\text { AZ:102/02A Central Pump Pit } \\
\text { Nozzle U10 }\end{array}$ & 2-in. SL-500 & 241-AX-A Valve Pit Nozzle L5 \\
\hline 241-AX-A Valve Pit Nozzle L3 & 2-in. SL-101 & 241-A-A Valve Pit Nozzle L9 \\
\hline 241-A-A Valve Pit Nozzle L18 & 2-in. SL-104 & $\begin{array}{l}\text { 241-A-B } \\
\text { Nozzle R18 }\end{array}$ \\
\hline 241-A-B Valve Pit Nozzle R3 & 2-in. SL-113 & $\begin{array}{l}\text { 242-A Evaporator } \\
\text { Nozzle } 16\end{array}$ \\
\hline $\begin{array}{l}\text { 242-A Evaporator } \\
\text { Nozzle } 18 \\
\end{array}$ & 2-in. SL-168 & 241-AW-A Valve Pit Nozzle L3 \\
\hline $\begin{array}{l}241-\mathrm{AW}-\mathrm{A} \\
\text { Nozzle LA }\end{array}$ & 2-in. SL-510 & 241-AP Valve Pit Nozzle 2 \\
\hline $\begin{array}{l}\text { 241-AP Valve Pit } \\
\text { Nozzle 8/AP-106 } \\
\text { Nozzle 7/AP-108 } \\
\text { Nozzle 6/AP-107 }\end{array}$ & $\begin{array}{ll}2 \text {-in. } & \text { SL-516 } \\
\text { 2-in. } & \text { SL-518 } \\
\text { 2-in. } & \text { SL-517 }\end{array}$ & $\begin{array}{l}\text { 241-AP Valve Pit } \\
\text { AP-106/06A Nozzle A } \\
\text { AP-108/08A Nozzle A } \\
\text { AP-107/07A Nozzle A }\end{array}$ \\
\hline
\end{tabular}


WHC-SD-WM-ES-370

Revision 0

\subsubsection{Alternative 3 Transfer Route}

Alternative 3 makes use of existing 2-in. and 3-in. transfer lines. The alternative uses 2 -in. lines and then transitions to 3 -in. lines for the remainder of the transfer route. Additionally, this alternative passes through the AW-102-02A central pump pit. Transferred waste would be accumulated either in the AP-107 tank or transferred directly to the private contractor's site via a by-pass jumper being installed into the selected AP tank central pump pit. The private contractor would need to install a HLW transfer line to the central pump pit.

Table 5-4 provides a detailed listing of the transfer lines and waste transfer pits and facilities that will be used by this alternative. Rigid jumpers will have to be fabricated to support establishing this waste transfer route. It is estimated the five to seven new jumpers will be required to implement this routing at an estimated cost of $\$ 25,000$ each. Fabrication of the jumpers will be the responsibility of DOE/PHMC.

The total head loss for Alternative 3 is $165 \mathrm{~m}$ or $2.3 \mathrm{MPa}$ to the $241-\mathrm{AP}-107$ Tank and $195 \mathrm{~m}$ or $2.7 \mathrm{MPa}$ to the private contractor. For this alternative, a flow rate of $8.8 \mathrm{~L} / \mathrm{min}$ is required to maintain a minimum velocity of $1.9 \mathrm{~m} / \mathrm{sec}$ in the 3 -in. transfer lines. This flow rate generates large head losses in the 2-in. SL-500 pipeline.

This transfer routing does not interfere with the operation of the 242-A Evaporator. However, a booster pump is required for transfers to either the 241-AP-107 tank or directly to the private contractor's site. In addition, the pressures required to pump to these locations are well over the design pressures of some of the transfer lines utilized. The design pressures of pipelines SN-201/214, SN-220, SN-271, and SN-268 may need to be increased. There are no cleanout boxes in these transfer lines, but further analysis is still required to determine if the design pressure of these pipelines can be increased to meet the needs of this alternative. 
WHC-SD-WM-ES-370

\section{Revision 0}

Table 5-4. Alternative 3 Transfer Route.

\begin{tabular}{|c|c|c|}
\hline From process pit & Transfer line & To process pit \\
\hline $\begin{array}{l}\text { AZ-102/02A Central Pump Pit } \\
\text { Nozzle U10 }\end{array}$ & 2-in. SL-500 & 241-AX-A Valve Pit Nozzle L5 \\
\hline 241-AX-A Valve Pit Nozzle L1 & 3-in. SN-214/201 & 241-A-A Valve Pit Nozzle L1 \\
\hline 241-A-A Valve Pit Nozzle L2 & 3-in. SN-220 & $\begin{array}{l}\text { 241-AW-A Valve Pit Nozzle } \\
\text { L2 }\end{array}$ \\
\hline 241-AW-A Valve Pit Nozzle L19 & 3-in. SN-271 & $\begin{array}{l}\text { 241-AW-B Valve Pit Nozzle } \\
\text { R19 }\end{array}$ \\
\hline 241-AW-B Valve Pit Nozzle R1 & 3-in. SN-268 & $\begin{array}{l}\text { AW-102/02A Central Pump Pit } \\
\text { Nozzle H }\end{array}$ \\
\hline $\begin{array}{l}\text { AW-102/02A Central Pump Pit } \\
\text { Nozzle U }\end{array}$ & 3 -in. SN-610 & 241-AP Valve Pit Nozzle 13 \\
\hline $\begin{array}{l}\text { 241-AP Valve Pit Nozzle 21/AP- } \\
106 \\
\text { Nozzle 22/AP-108 } \\
\text { Nozzle 23/AP-107 }\end{array}$ & $\begin{array}{l}3 \text {-in. SN-616 } \\
3 \text {-in. SN-618 } \\
3 \text {-in. SN-617 }\end{array}$ & $\begin{array}{ll}\text { 241-AP Valve Pit } \\
\text { AP-106/06A } & \text { Nozzle A } \\
\text { AP-108/08A } & \text { Nozzle A } \\
\text { AP-107/07A } & \text { Nozzle A }\end{array}$ \\
\hline
\end{tabular}




\section{WHC-SD-WM-ES-370 \\ Revision 0}

Figure 5-3. Transfer Routes for Alternatives 3 and 4.
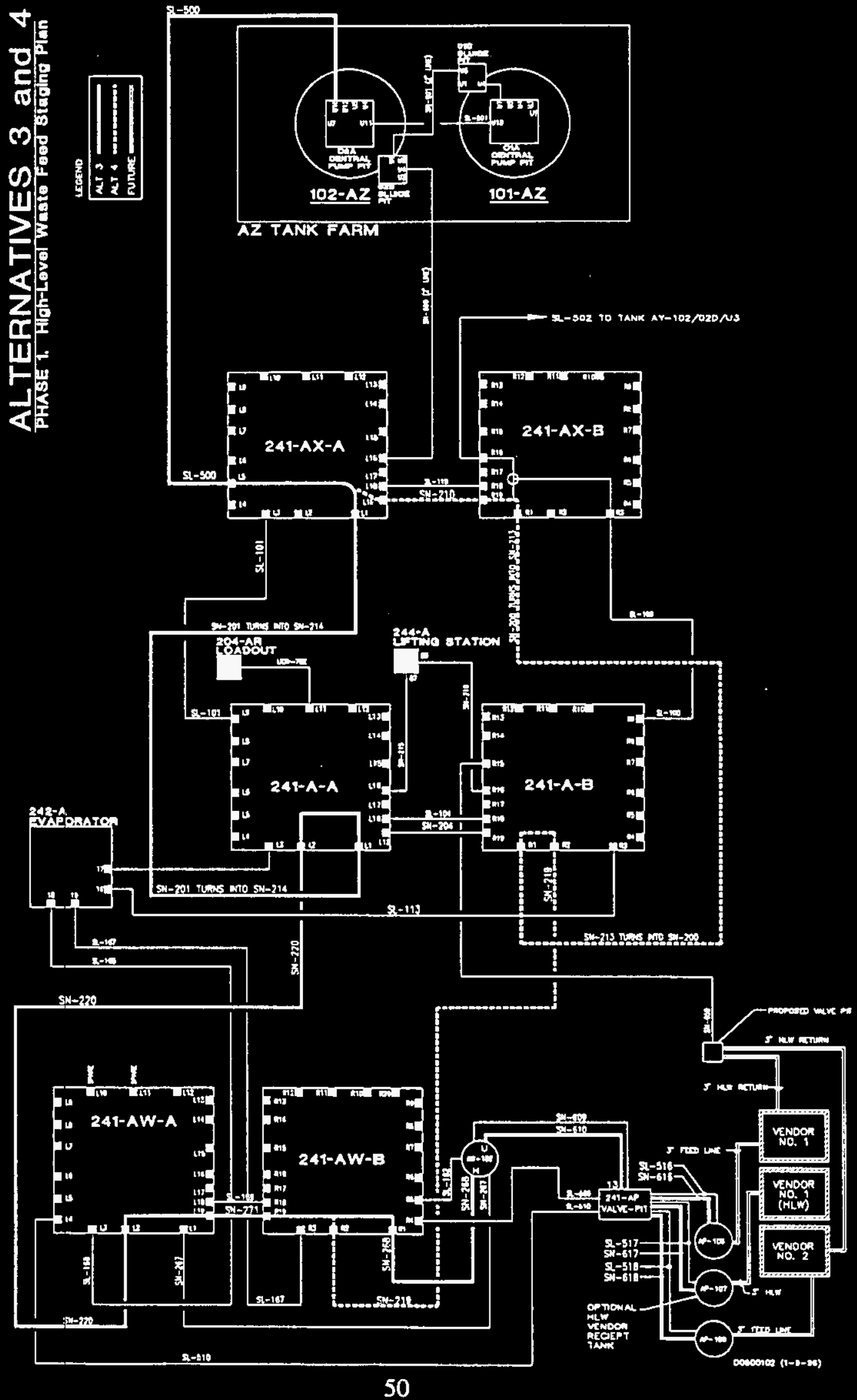
WHC-SD-WM-ES-370

Revision 0

\subsubsection{Alternative 4 Transfer Route}

Alternative 4 is similar to Alternative 3 with the exception of using an alternate route between 241-A-A to 241-A-B valve pits and 241-A-B to 241-AW-B valve pits.

Table 5-5 provides a detailed listing of the transfer lines and waste transfer pits and facilities that will be used by this alternative. Rigid jumpers will have to be fabricated to support establishing this waste transfer route.

The total head loss for Alternative 4 is $165 \mathrm{~m}$ or $2.3 \mathrm{MPa}$ to the $241-\mathrm{AP}-107$ Tank and $195 \mathrm{~m}$ or $2.7 \mathrm{MPa}$ to the private contractor.

The advantages and disadvantages are the same as for Alternative 3. However, for Alternative 4 lines SN-210, SN-200/213, and SN-219 have the lowest design pressure of 1.6 MPa. Again, it may be possible to upgrade the design pressure of these lines with further analysis.

Table 5-5. Alternative 4 Transfer Route.

\begin{tabular}{|l|c|l|}
\hline \multicolumn{1}{|c|}{ From process pit } & Transfer line & \multicolumn{1}{|c|}{ To process pit } \\
\hline $\begin{array}{l}\text { AZ-102/02A Central Pump Pit } \\
\text { Nozzle U10 }\end{array}$ & 2-in. SL-500 & 241-AX-A Valve Pit Nozzle L5 \\
\hline 241-AX-A Valve Pit Nozzle L19 & 3-in. SN-210 & 241-AX-B Valve Pit Nozzle R19 \\
\hline 241-AX-B Valve Pit Nozzle R1 & $\begin{array}{l}\text { 3-in. SN- } \\
213 / 200\end{array}$ & $241-A-B$ Valve Pit Nozzle R1 \\
\hline 241-A-B Valve Pit Nozzle R2 & 3 -in. SN-219 & $\begin{array}{l}\text { 241-AW-B } \\
\text { Nozzle R2 }\end{array}$ \\
\hline $\begin{array}{l}\text { 241-AW-B } \\
\text { Nozzle R1 }\end{array}$ & 3 -in. SN-268 & $\begin{array}{l}\text { AW-102/02A Central Pump Pit } \\
\text { Nozzle H }\end{array}$ \\
\hline $\begin{array}{l}\text { AW-102/02A Central Pump Pit } \\
\text { Nozzle U }\end{array}$ & 3-in. SN-610 & 241-AP Valve Pit Nozzle 13 \\
\hline $\begin{array}{l}\text { 241-AP Valve Pit } \\
\text { Nozzle 21/AP-106 } \\
\text { Nozzle 22/AP-108 } \\
\text { Nozzle 23/AP-107 }\end{array}$ & $\begin{array}{l}\text { 3-in. SN-616 } \\
\text { 3-in. SN-618 }\end{array}$ & $\begin{array}{l}\text { AP-106/06A N-617 } \\
\text { AP-108/08A Nozzle A } \\
\text { AP-107/07A Nozzle A }\end{array}$ \\
\hline
\end{tabular}


WHC-SD-WM-ES-370

Revision 0

\subsubsection{Alternative 5 Transfer Route}

This alternative makes use of existing 2 -in. and 3 -in. transfer lines. The alternative uses 2-in. lines to the maximum extent possible and then transitions to 3-in. lines for the remainder of the transfer route. This alternative additionally uses 3-in. transfer line SN-650, which currently ends at AP-102 tank. This line entries directly into the tank and does not have a process pit. It is assumed that the private contractor will construct a process pit, with jumpers, and route new lines to their facilities. This option will require that the private contractor install a small receipt tank in their facility to receive the HLW product; the tank size is assumed to be a $190-\mathrm{m}^{3}$ to $379-\mathrm{m}^{3}$ tank.

Table 5-6 provides a detailed listing of the transfer lines and waste transfer pits and facilities that will be used by this alternative. Rigid jumpers will have to be fabricated to support establishing this waste transfer route.

Table 5-6. Alternative 5 Transfer Route.

\begin{tabular}{|l|c|l|}
\hline \multicolumn{1}{|c|}{ From process pit } & Transfer line & \multicolumn{1}{c|}{ To process pit } \\
\hline $\begin{array}{l}\text { AZ-102/02A Central Pump Pit } \\
\text { Nozzle U10 }\end{array}$ & 2-in. SL-500 & 241-AX-A Valve Pit Nozzle L5 \\
\hline 241-AX-A Valve Pit Nozzle L19 & 3-in. SN-210 & 241-AX-B Valve Pit Nozzle R19 \\
\hline 241-AX-B Valve Pit Nozzle R1 & 3-in. SN-200/213 & 241-A-B Valve Pit Nozzle R1 \\
\hline 241-A-B Valve Pit Nozzle R15 & 3-in. SN-650 & $\begin{array}{l}\text { "New private contractor's } \\
\text { process pit" }\end{array}$ \\
\hline
\end{tabular}

The total head loss for Alternative 5 is $149 \mathrm{~m}$ or $2.1 \mathrm{MPa}$ to the new Valve Pit and $183 \mathrm{~m}(605 \mathrm{ft})$ or $2.5 \mathrm{MPa}$ to the private contractor. For this alternative a flow rate of $8.8 \mathrm{E}-03 \mathrm{~m} \mathrm{~m}^{3} / \mathrm{min}$ is required to maintain a minimum velocity of $1.9 \mathrm{~m} / \mathrm{sec}$ in the 3 -in. transfer lines. This flow rate generates large head losses in the 2-in. SL-500 pipeline.

This transfer routing does not interfere with the operation of the 242-A Evaporator. However, a booster pump is required for transfers to either the new valve pit or directly to the private contractor's site. In addition, the pressures required to pump to these locations are well over the design pressures of the some of the transfer lines utilized. The design pressures of pipelines SN-210 and SN-200/213 may need to be increased. There are no cleanout boxes in these transfer lines, but further analysis is still required to determine if the design pressure of these pipelines can be increased to meet the needs of this alternative.

In addition to installing a new valve pit and associated drain lines and jumpers, Alternative 5 requires that the private contractor have a $190-\mathrm{m}^{3}$ to $379-\mathrm{m}^{3}$ tank in the processing plant for interim staging of the HLW product. 
WHC-SD-WM-ES-370

Revision 0

Figure 5-4. Alternative 5 Transfer Route.

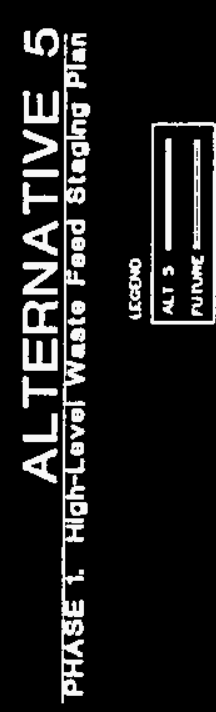

son
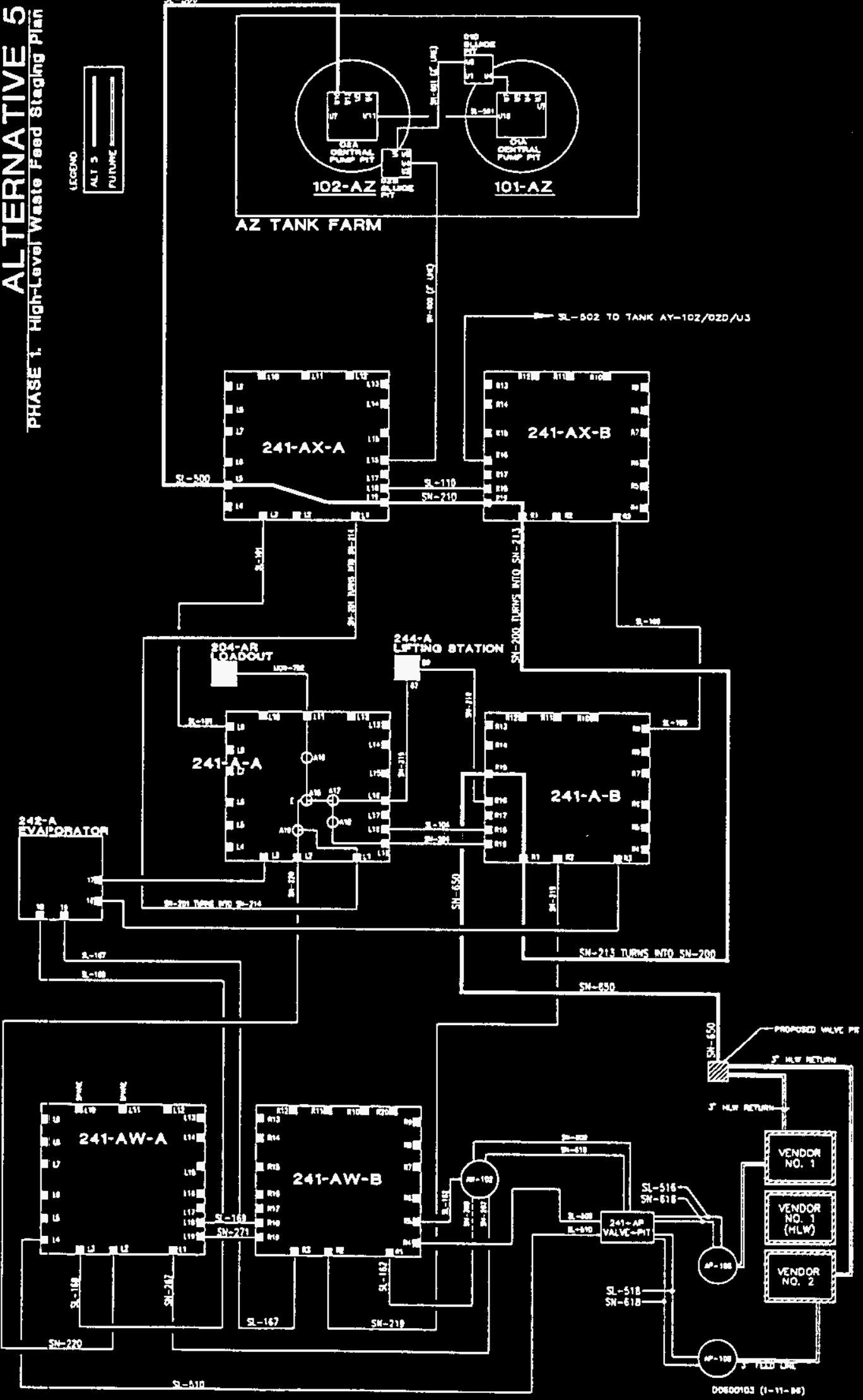
WHC-SD-WM-ES-370

Revision 0

\subsubsection{Alternative 6 Transfer Route}

This alternative uses existing 2 -in. and 3-in. transfer lines. The alternative will use 2-in. lines to the maximum extent possible then transition/convert to 3-in. lines and then back to 2-in. when exiting the 241-AW Tank Farm and would also use 2-in. lines from AP valve pit to the private contractor's receipt tank. The waste could be transferee directly to an AP Tank Farm feed/receipt tank or transferred directly to a private contractor's in-plant receipt/staging tank via a by-pass jumper being installed in the designated AP tank central pump pit. The jumper would be connected to the private contractor's installed HLW feed line.

Table 5-7 provides a detailed listing of the transfer lines and waste transfer pits and facilities that will be used by this alternative. Rigid jumpers will have to be fabricated to support establishing this waste transfer route.

The total head loss for Alternative 6 is $409 \mathrm{~m}$ or $5.6 \mathrm{MPa}$ to the 241-AP-107 tank and $635 \mathrm{~m}$ or $8.8 \mathrm{MPa}$ to the private contractor. For this alternative a flow rate of $8.8 \mathrm{~L} / \mathrm{min}$ is required to maintain a minimum velocity of $1.9 \mathrm{~m} / \mathrm{sec}$ in the transition to the $3-\mathrm{in}$. SN-220 pipeline. This flow rate generates large head losses in the remaining 2-in. SL pipelines. The extremely large head and pressure requirements for this alternative make Alternative 6 an unacceptable waste routing.

Table 5-7. Alternative 6 Transfer Route.

\begin{tabular}{|l|c|l|}
\hline \multicolumn{1}{|c|}{ From process pit } & Transfer line & \multicolumn{1}{c|}{ To process pit } \\
\hline $\begin{array}{l}\text { AZ-102/02A Central Pump Pit } \\
\text { Nozzle U10 }\end{array}$ & 2-in. SL-500 & 241-AX-A Valve Pit Nozzle L5 \\
\hline 241-AX-A Valve Pit Nozzle L3 & 2-in. SL-101 & 241-A-A Valve Pit Nozzle L9 \\
\hline 241-A-A Valve Pit Nozzle L2 & 3-in. SN-220 & 241-AW-A Valve Pit Nozzle L2 \\
\hline 241-AW-A Valve Pit Nozzle L4 & 2-in. SL-510 & 241-AP Valve Pit Nozzle 2 \\
\hline 241-AP Valve Pit & & Tank Central Pump Pit \\
Nozzle 8/AP-106 & 2-in. SL-516 & $\begin{array}{l}\text { AP-106/O6A Nozzle B } \\
\text { Nozzle 7/AP-108 }\end{array}$ \\
Nozzle 6/AP-107 & 2-in. SL-518 & $\begin{array}{l}\text { AP-108/08A Nozzle B } \\
\text { AP-107/07A Nozzle B }\end{array}$ \\
\hline
\end{tabular}


WHC-SD-WM-ES-370

Revision 0

Figure 5-5. Alternative 6 Transfer Route.
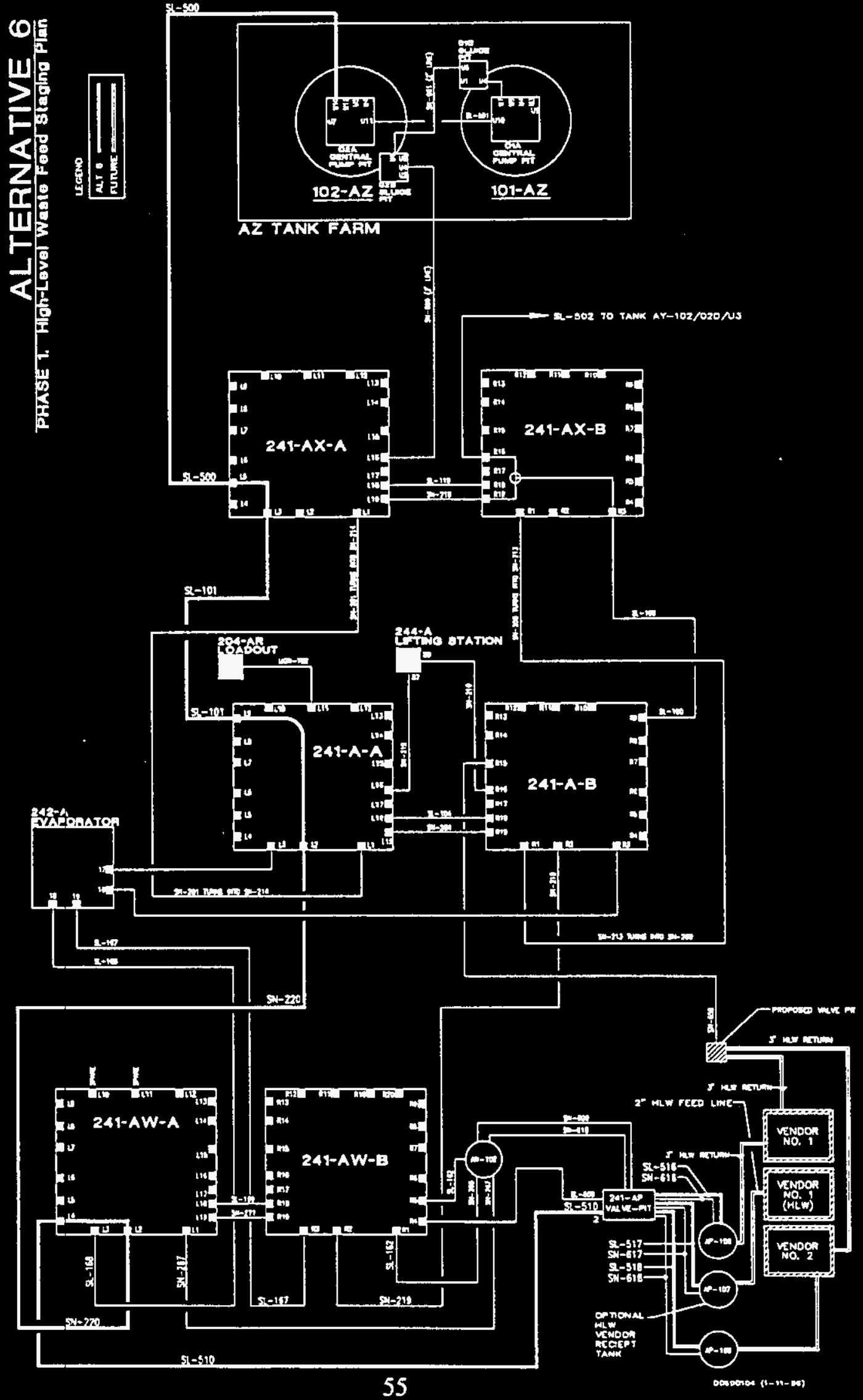
WHC-SD-WM-ES-370

Revision 0

\subsubsection{Alternative 7 Transfer Route}

Alternative 7 uses a new 3-in in 6-in transfer line. The new line would originate at the 241-AZ-02A pump pit and run along the east side of the A Farm Complex to the private contractor's HLW processing facility. The alternative is illustrated in Figure 5-6.

This alternative will require approximately $1,818 \mathrm{~m}$ of new piping to be constructed. It is anticipated that this would be a DOE/PHMC cost. The ROM estimate for transfer system is $\$ 10$ million.

The total head loss for Alternative 7 is $131 \mathrm{~m}$ or $1.8 \mathrm{MPa}$ to the private contractor.

This alternative meets all of the criteria stated in Section 5.1 with the exception of not minimizing the upgrades to the existing A Farm Complex. Besides requiring approximately $1,818 \mathrm{~m}$ of new piping, Alternative 7 will require that the private contractor have a $190-\mathrm{m}^{3}$ to $379-\mathrm{m}^{3}$ tank in the processing plant for interim staging of the HLW product. In addition, a vent station may be required at the high point of this new transfer line.

\subsubsection{Alternative 8 Transfer Route}

This alternative uses a new 3-in. transfer line from the 241-AZ-02B sluice pit to the 241-AX-A valve pit. The transfer route is then identical to Alternative 4, which uses existing 3-in. SN lines to the AP farm and from there via a new 3-in. line to the private contractor's facility. A schematic of this waste routing system is shown in Figure 5-7. The total head loss for Alternative 8 is $92 \mathrm{~m}$ or $1.3 \mathrm{MPa}$ to the AP tank farm tank and $122 \mathrm{~m}$ or $1.7 \mathrm{MPa}$ to the private contractor. Figure 5-7 also shows the alternative of routing the waste to an AP tank farm tank.

This alternative meets all of the criteria stated in Section 5.1 with the exception of not minimizing the upgrades to the existing A Farm Complex. Project W-314 is proposing a new 3-in. transfer route from the 241-AZ-02B sluice pit to the 241-AX-A valve pit. The cost of this new transfer line is estimated to be around $\$ 1$ million. In addition, Alternative 8 requires a system pressure that is around 10 percent higher than the design pressure of pipelines SN-210, SN-200/213, and SN-219. However, it should be possible to show that these lines could handle the increased pressure. There are no cleanout boxes in these transfer lines, but further analysis is still required to determine if the design pressure can be increased to meet the needs of this alternative. 
WHC-SD-WM-ES-370

Revision 0

Figure 5-6. Alternative 7 Transfer Route.
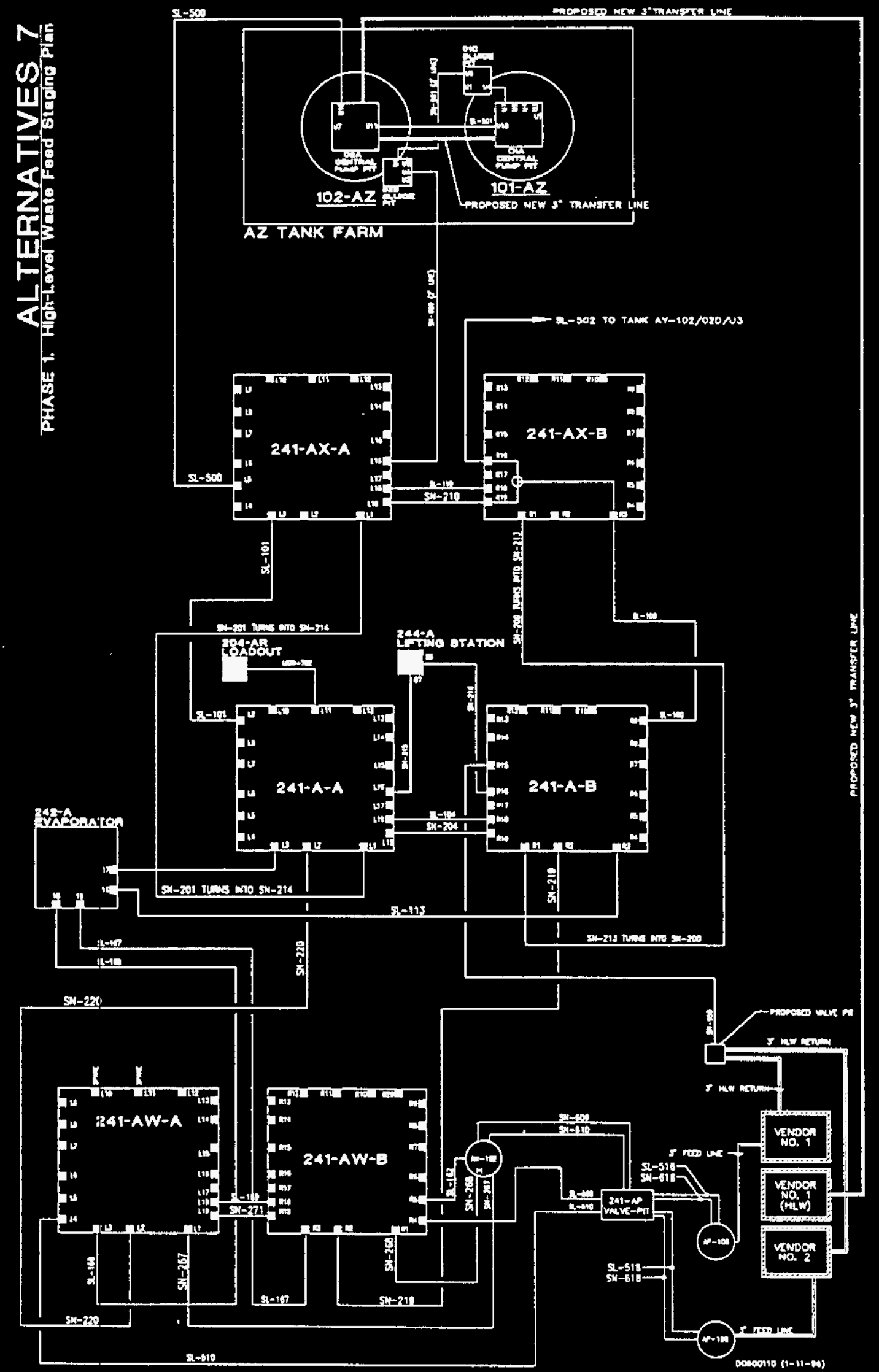
WHC-SD-WM-ES-370

Revision 0

Figure 5-7. Alternative 8 Transfer Route.
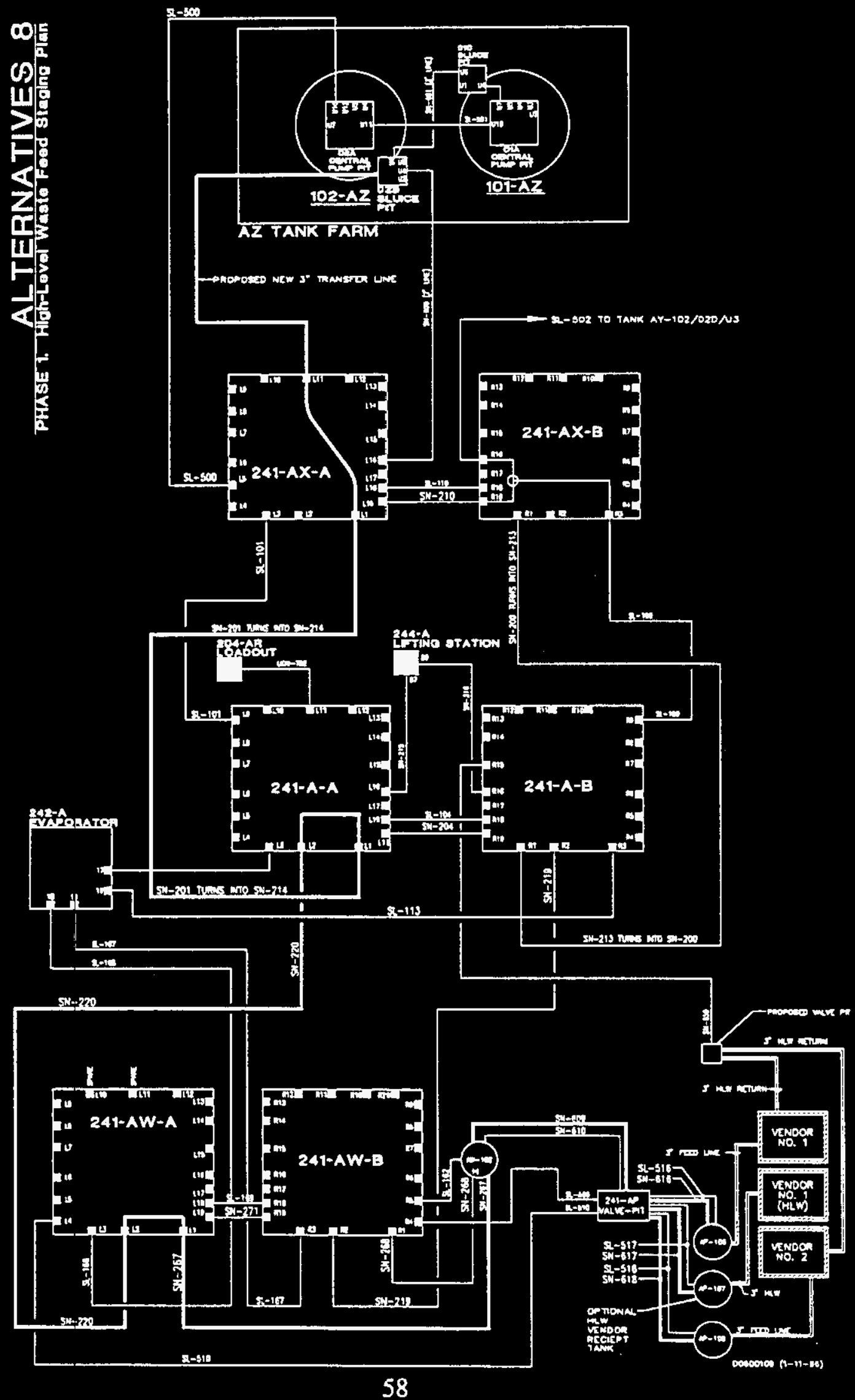
WHC-SD-WM-ES-370

Revision 0

\subsection{SCHEDULE}

Figure 5-8 shows a preliminary schedule for the sludge consolidation, pretreatment, equipment installation, and transfer of the HLW feed slurry to the private contractor at $10 \mathrm{wt} \%$ insoluble solids. Ten $379-\mathrm{m}^{3}$ feed batches are delivered between June 1,2002 , and June 1,2007 , to supply a minimum of 190 MT of waste oxides (excluding sodium and silicon). For planning purposes, it is assumed that there will be two batch transfers of HLW feed per fiscal year. The duration of each $379-\mathrm{m}^{3}$ transfer is approximately one day, at a transfer rate of $530 \mathrm{~L} / \mathrm{min}$.

The preliminary schedule depicted in Figure 5-8 identifies the need to conduct engineering analyses of the proposed HLW feed system, including design, fabrication, and installation of jumpers, and sampling of washed sludges in preparation for supplying feed to the privatization contractor. These activities need to be conducted during fiscal years 1996 and 2001. 
WHC-SD-WM-ES-370

Revision 0

Figure 5-8. Schedule.

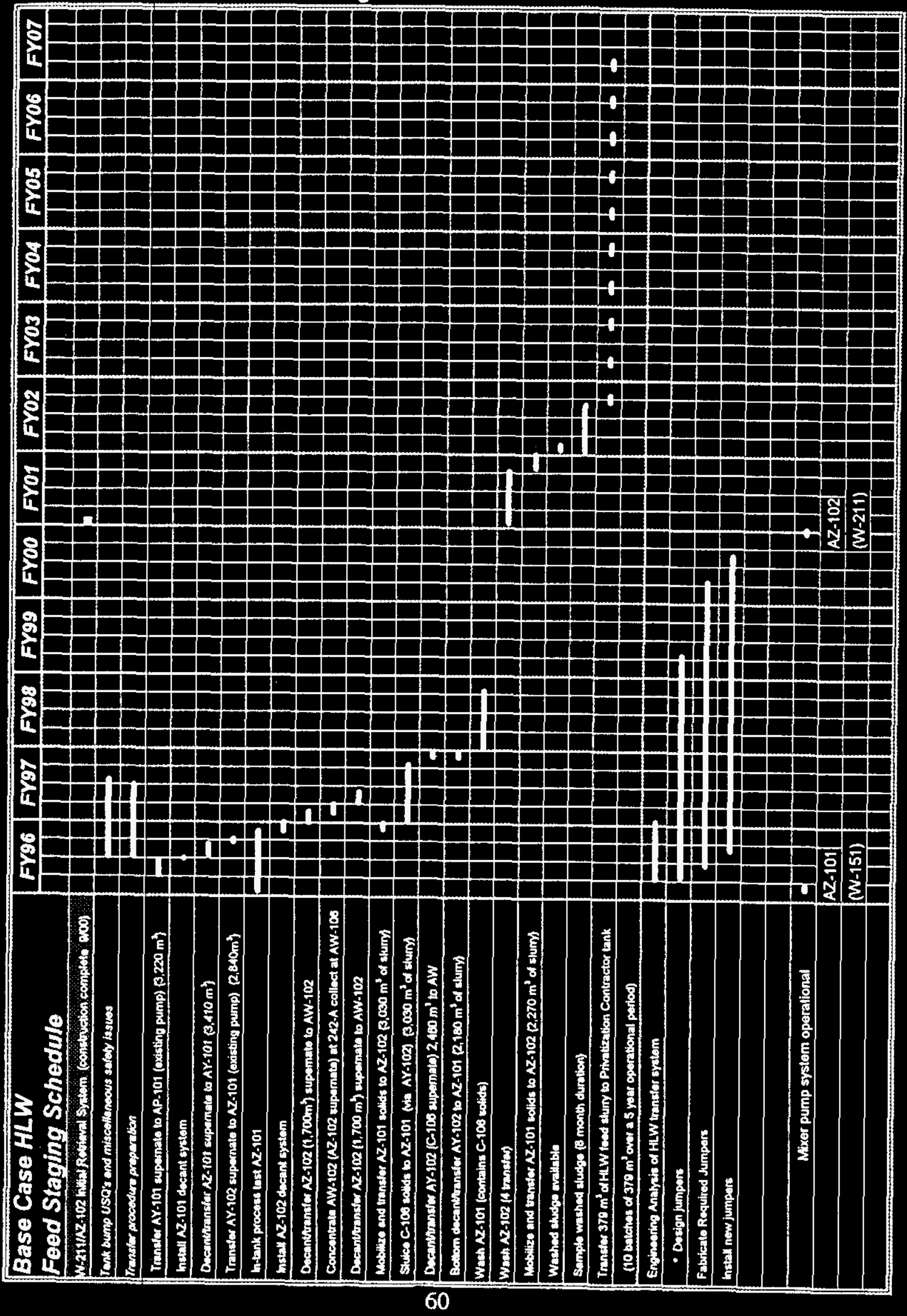


WHC-SD-WM-ES-370

Revision 0

\subsection{REFERENCES}

49 CFR 173, 1994, "Shippers-General Requirements for Shipments and Packagings," Code of Federal Regulations, as amended.

Agnew, S., 1994a, Estimating Chemical Inventories for Hanford Tank Wastes, LA-UR-94-273, Los Alamos National Laboratory, Los Alamos, New Mexico.

Agnew, S., 1994b, Hanford Defined Wastes: Chemical and Radionuclide Compositions, LA-UR-94-2657, Los Alamos National Laboratory, Los Alamos, New Mexico.

Bacon, R. F., 1995, Double-Shell Tank Waste Consolidation and Retrieval Planning Base Case, 75510-95-017 (August 30, 1995), Westinghouse Hanford Company, Richland, Washington.

Brevick, C. H., 1994, Historical Tank Content Estimate for the Northeast Quadrant of the Hanford 200 East Areas, WHC-SD-WM-ER-349, Rev. 0, Westinghouse Hanford Company, Richland, Washington.

Castaing, B. A., 1994, 101-AY, 102-AY, \& 106-C Data Compendium, WHC-SD-WM-TI-578, Rev. 1, Westinghouse Hanford Company, Richland, Washington.

Certa, P. J., C. M. McConville, and L. W. Shelton, 1996, Preliminary Low-Level Waste Feed Staging Plan, WHC-SD-WM-RPT-210, Rev. 0, Westinghouse Hanford Company, Richland, Washington.

Colton, N. G., 1995, Sludge Pretreatment Chemistry Evaluation: Enhanced Sludge Washing Separation Factors, PNL-10512, UC-721, Pacific Northwest Laboratory, Richland, Washingtion.

DOE, 1982, Environmental Assessment Waste Form Selection for SRP High-Level Waste, DOE/EA-0179, U.S. Department of Energy, Richland, Washington.

DOE, 1995a, TWRS Privatization Request for Proposals - Draft, DE-RP06-96RL13308, U.S. Department of Energy, Richland Operations, Richland, Washington.

DOE, 1995b, Tank Waste Remediation Systems Requirements Review, U.S. Department of Energy, Washington, D.C.

Grams, W. H., 1995, Double-Shell Tank Retrieval Allowable Heel Trade Analysis, WHC-SD-WM-TA-162, Rev. 0, Westinghouse Hanford Company, Richland, Washington. 
WHC-SD-WM-ES-370

Revision 0

Gray, W. J., M. E. Peterson, R. D. Scheele, and J. M. Tingey, 1993a, Characterization of the Second Core Sample of Neutralized Current Acid Waste from Double-Shell Tank 101-AZ, Pacific Northwest Laboratory, Richland, Washington.

Gray, W. J., M. E. Peterson, R. D. Scheele, and J. M. Tingey, 1993b, Characterization of the First Core Sample of Neutralized Current Acid Waste from Double-Shell Tank 102-AZ, Pacific Northwest Laboratory, Richland, Washington.

Herting, D. L., 1995, Caustic Washing of Sludge Samples from Tank 241-AZ-102, 75764-PCS95-086 (September 29, 1995), Westinghouse Hanford Company, Richland, Washington.

Hill, J. G., G. S. Anderson, and B. C. Simpson, 1995, The Sort on Radioactive Waste Type Model: A Method to Sort Single-Shell Tanks into Characteristic Groups, PNL-9814, Rev. 2, Facific Northwest Laboratory, Richland, Washington.

Hrma, P. R., G. F. Piepel, M. J. Schweiger, D. E. Smith, D. S. Kim, P. E. Redgate, J. D. Vienna, C. A. LoPresti, D. B. Simpson, D. K. Peeler, and M. H. Langowski, 1994, Property/Composition Relationships for Hanford High-Level Waste Glasses Melting at $1150{ }^{\circ} \mathrm{C}$, Volume 1, PNL-10359, Pacific Northwest Laboratory, Richland, Washington.

Kalia, J., 1994, Hanford Waste Vitrification Plant Project Technical Data Package, Revision 5, WHC-SD-HWV-DP-001, Westinghouse Hanford Company, Richland, Washington.

Koreski, G. M., and J. N. Strode, 1995, Operational Waste Volume Projection, WHC-SD-WM-ER-029, Rev. 21, Westinghouse Hanford Company, Richland, Washington.

Orme, R. M., 1995, TWRS Process Flowsheet - Revision 1, WHC-SD-WM-TI-613, Westinghouse Hanford Company, Richland, Washington.

Peterson, M. E., et al., 1993, Characterization of the First Core Sample of Neutralized Current Acid Waste from Double-Shell Tank 101-AZ, Pacific Northwest Laboratory, Richland, Washington.

Powell, W. J., 1996, NCAW Consolidation Management Plan, WHC-SD-WM-ER-532, Rev. 0, Westinghouse Hanford Company, Richland, Washington.

Rapko, B. M., et al., 1995, Washing and Caustic Leaching of Hanford Sludges: Results of FY 1995 Studies, TWRSPP-95-021, Pacific Northwest Laboratory, Richland, Washingtion. 
Shelton, L. W., 1995, Internal Memo, L. W. Shelton to R. M. Orme, Chemical and Radionuclide Inventory for Single and Double-Shell Tanks, 75520-95-007, Westinghouse Hanford Company, Richland, Washington.

Vienna, J. D., and P. R. Hrma, 1995, Glass Formulation for Phase I High-Level Waste Vitrification, Pacific Northwest Laboratory, Richland, Washington.

Weiss, 1988, Data Transmittal Package for 241-C-106 Waste Tank Characterization, SD-RE-TI-205, Westinghouse Hanford Company, Richland, Washington.

WHC, 1995, Tank Waste Remediation System Functions and Requirements, WHC-SD-WM-FRD-020, Rev. B, Westinghouse Hanford Company, Richland, Washington. 
WHC-SD-WM-ES-370

Revision 0

This page intentionally left blank. 
WHC-SD-WM-ES-370

Revision 0

APPENDIX A

TANK WASTE INVENTORY ASSUMPTIONS AND METHODOLOGY

A-1 
WHC-SD-WM-ES-370

Revision 0

This page intentionally left blank. 
WHC-SD-WM-ES-370

Revision 0

APPENDK A

TANK WASTE INVENTORY ASSUMPTIONS AND METHODOLOGY

The tank waste inventories used in this analysis consist of the best analytical information available. For single-shell tank 106-C, and double-shell tanks 101-AZ and $102-\mathrm{AZ}$, the inventories and solubility data represent a change from the values reported in the TWRS Process Flowsheet (Orme 1995). The revised inventory assumptions will be integrated into the next release of the flowsheet. Tables A-1 through A-4 contain the revised inventory assumptions for the Phase I high-level waste source tanks.

Tables A-5 through A-14 show the progressive change in the composition of the retrieved waste in 101-AZ and 102-AZ after each wash of the sludge. This assumes the minimum recovery fractions and the Bacon (1995) consolidation case. Tables A-5 through A-9 are for successive dilute caustic washes (4 total). Tables A-10 through A-14 are for caustic leaching followed by successive dilute caustic washes (1 caustic wash, 3 dilute caustic washes). The purpose of these tables is to quantify the impacts of alternative pretreatment strategies on the low-level waste feed (Section 4.6.5). 
WHC-SD-WM-ES-370

Revision 0

Table A-1. Rovisad 241-C-10s Inventory (Woise 19:3)

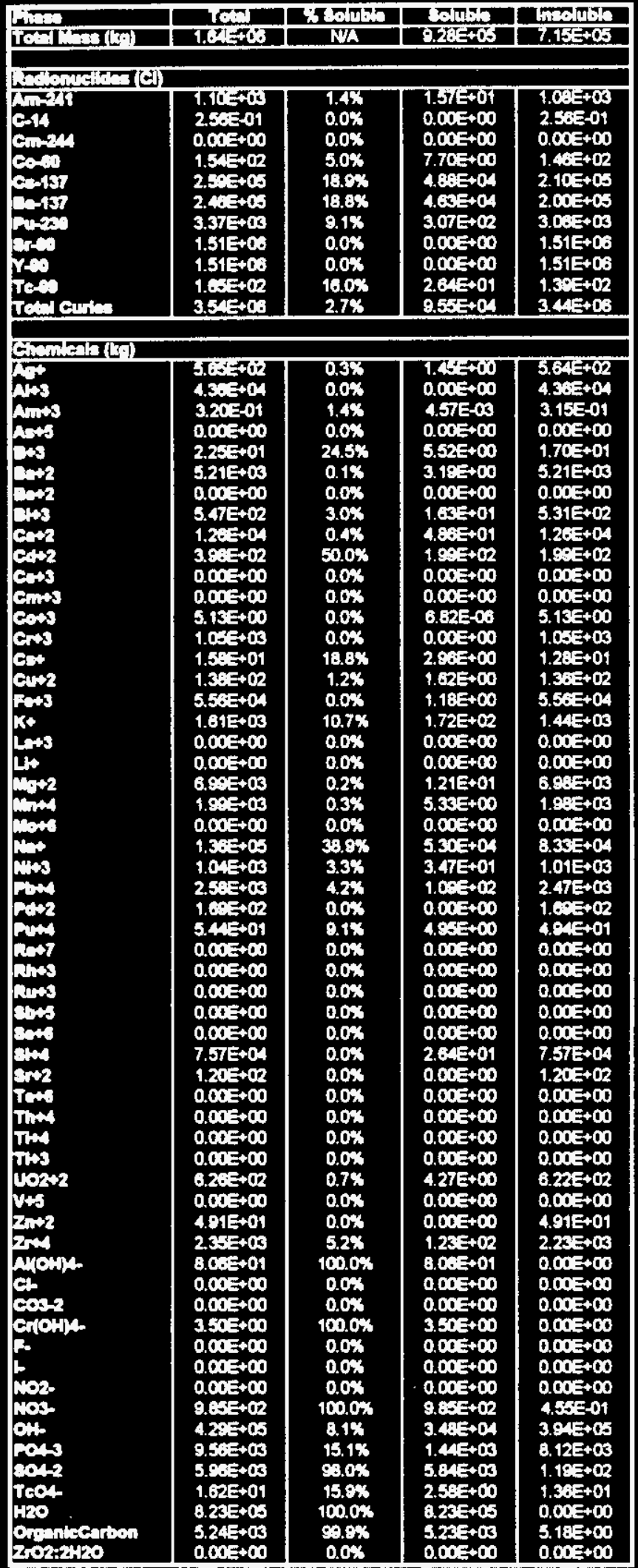


WHC-SD-WM-ES-370

Revision 0

Table A-2. Rovised 241-A2-101 lowentory

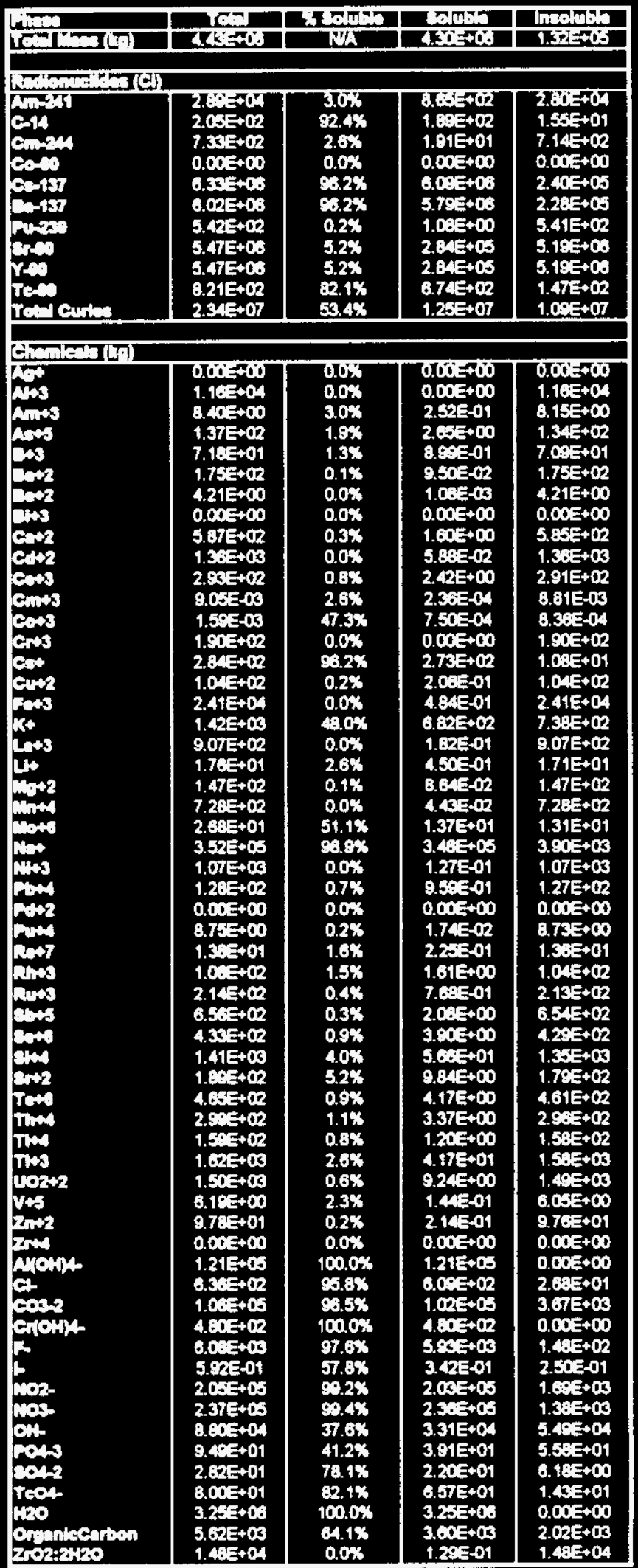


WHC-SD-WM-ES-370

Revision 0

Tobis A-3. Roviead 244-12-102 lowentory

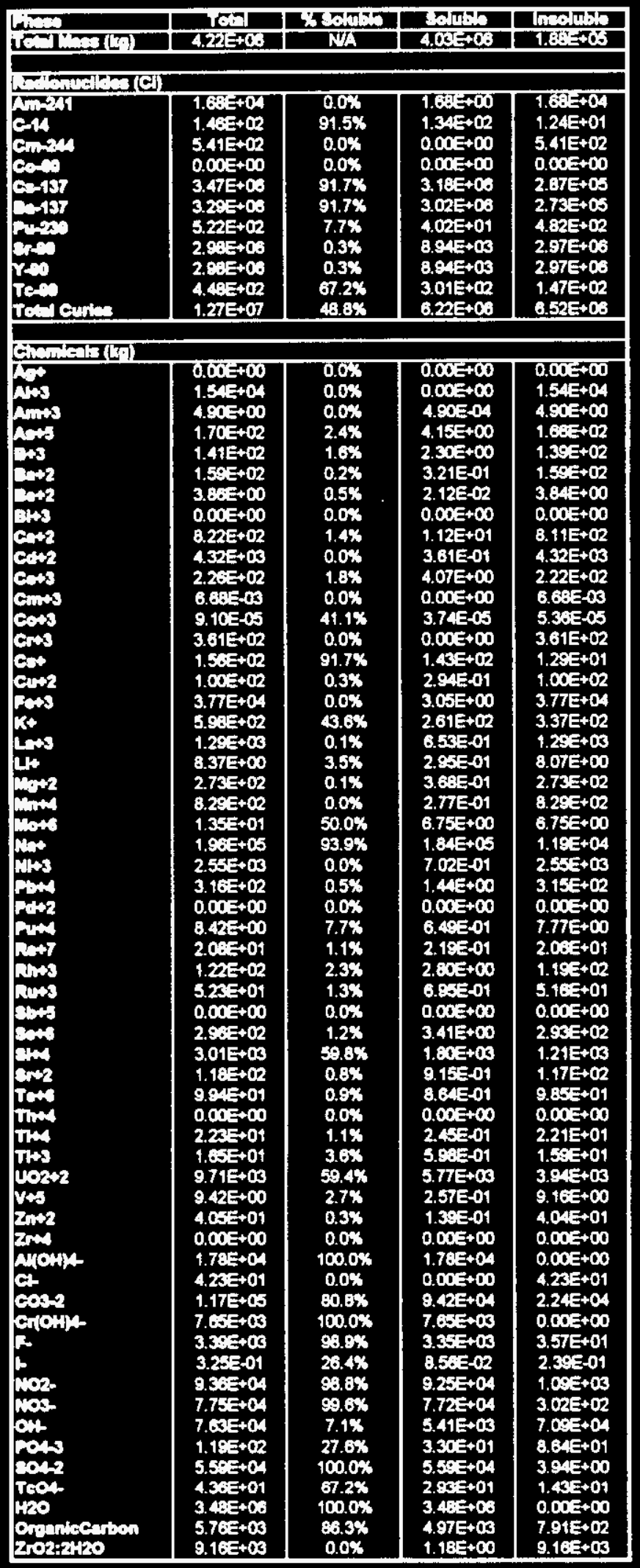


WHC-SD-WM-ES-370
Revision 0

Table A-4. 241-AY-102 Inventory (Orme 1896)

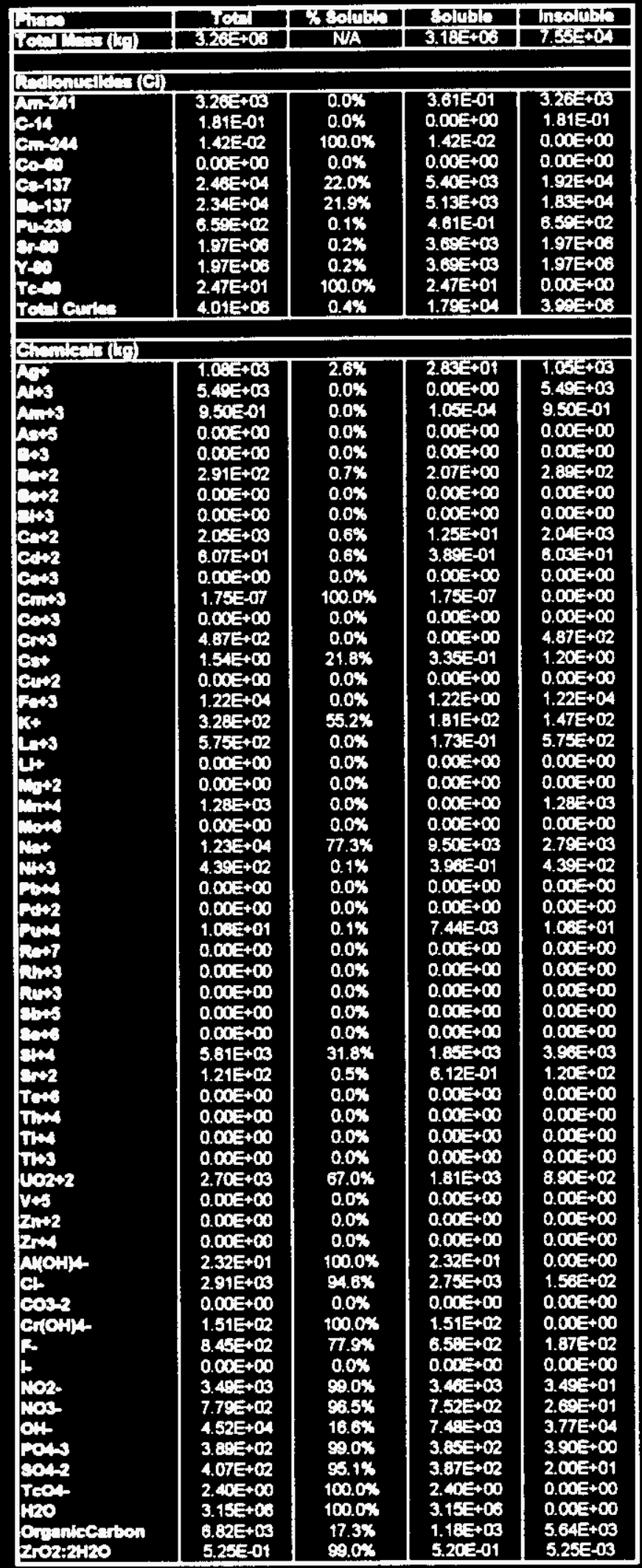


HWW and LW Inventories after No Waches (Decant Only)

\begin{tabular}{|c|c|c|c|}
\hline Gines & $\sin$ & 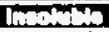 & $T+\infty$ \\
\hline 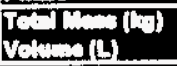 & $\begin{array}{l}1.0+5 \times 03 \\
1.0+5 \times 00\end{array}$ & $\begin{array}{l}2.9+60 \\
1.80=+05\end{array}$ & $\begin{array}{l}1.35 E+03 \\
1.225+06\end{array}$ \\
\hline \multicolumn{4}{|l|}{ Redlownellina (e) } \\
\hline 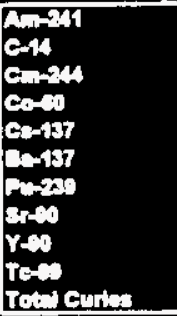 & 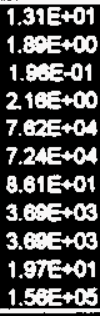 & $\begin{array}{l}6.82 E=+02 \\
250 E-01 \\
7.12 E=+00 \\
5.42 E+01 \\
8.06=+04 \\
7.66 E+04 \\
1.15 E+03 \\
6.18 E+05 \\
6.18 E+\infty 5 \\
5.34=+01 \\
1.405+03\end{array}$ & $\begin{array}{l}6 . E J E+02 \\
2.14 E+00 \\
7.32 E+\infty \\
5.61 E+01 \\
1.57 E+06 \\
1.40 E+06 \\
1.24 E+03 \\
6.22 E+05 \\
6.22 E+05 \\
7.31 E+01 \\
1.56 E+06\end{array}$ \\
\hline
\end{tabular}

\begin{tabular}{|c|c|c|c|}
\hline $\mathrm{P}_{1}:=$ & Bandes & 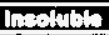 & Tat \\
\hline 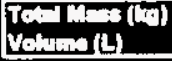 & $\begin{array}{l}1.02=+06 \\
249=+06\end{array}$ & $\begin{array}{l}2.50=+06 \\
1.50=+05\end{array}$ & $\begin{array}{l}1.27 \mathrm{E}+06 \\
1.11 \mathrm{E}+00\end{array}$ \\
\hline \multicolumn{4}{|c|}{ 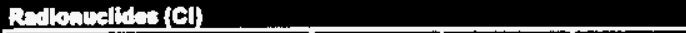 } \\
\hline $\begin{array}{l}\operatorname{con}_{2} \sin \\
\operatorname{con}-24\end{array}$ & $\begin{array}{l}3.03 E+01 \\
1.82 E+01 \\
6.60 E-01\end{array}$ & $\begin{array}{l}3.54 E+04 \\
2.21 E+01 \\
9.98 E+02\end{array}$ & $\begin{array}{l}3.54 E+04 \\
4.03 E+01 \\
9.90 E+02\end{array}$ \\
\hline Ce-137 & $4.91 E+05$ & $4.18 E+05$ & $9.095+05$ \\
\hline $20-497$ & $4.87 E+06$ & $3.985+05$ & $8.65 E+05$ \\
\hline Purage & $3.620 \times 00$ & 8.12 $E+02$ & $8.16 E+02$ \\
\hline $5 \times 10$ & 1.13E+04 & 6.45E+03 & $6.465+66$ \\
\hline$Y=0$ & $1.13 E+04$ & $6.45 E+06$ & $6.46 E+06$ \\
\hline Totel Curies & $\begin{array}{l}5.35=+01 \\
9.80 E+05\end{array}$ & $\begin{array}{l}2.35=+02 \\
1.385+07\end{array}$ & $\begin{array}{l}2.87 E+02 \\
1.48 E+07\end{array}$ \\
\hline
\end{tabular}

\begin{tabular}{|c|c|c|c|}
\hline 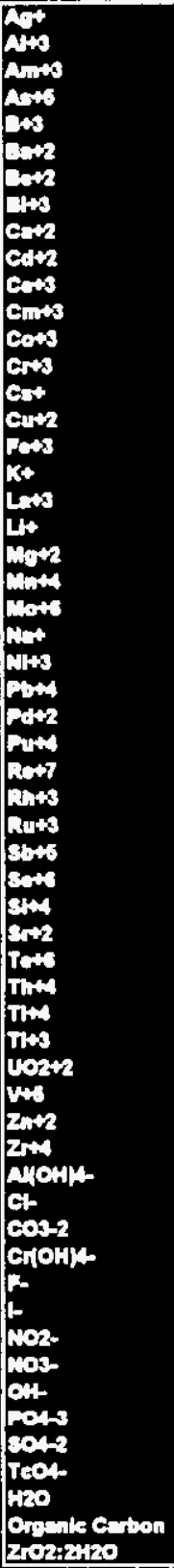 & 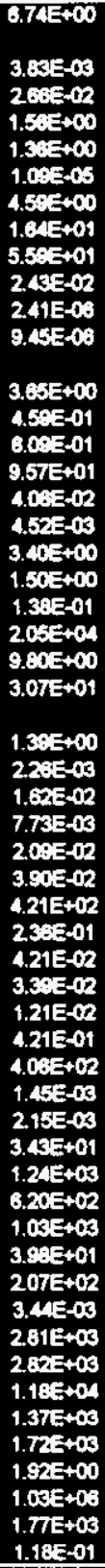 & 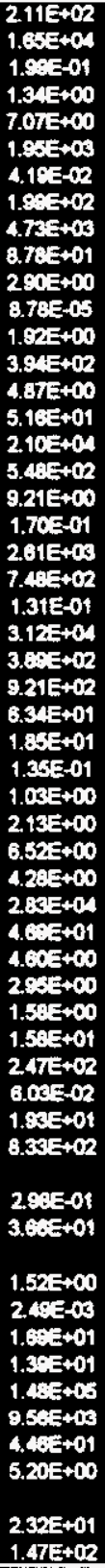 & 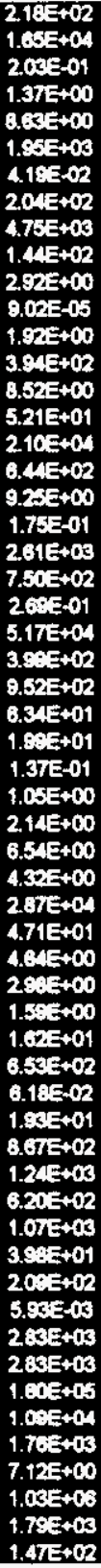 \\
\hline
\end{tabular}

\begin{tabular}{|c|c|c|c|}
\hline 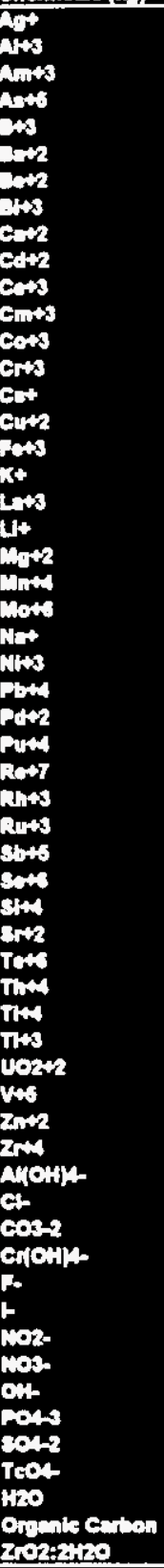 & 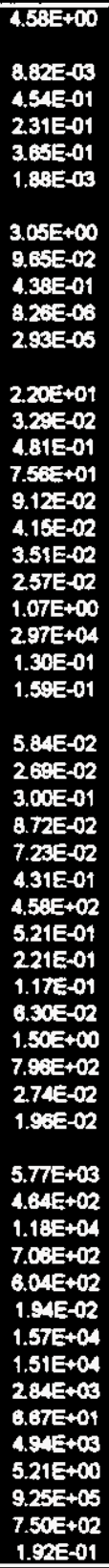 & 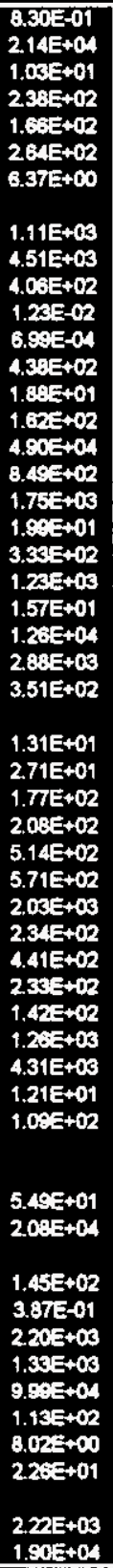 & 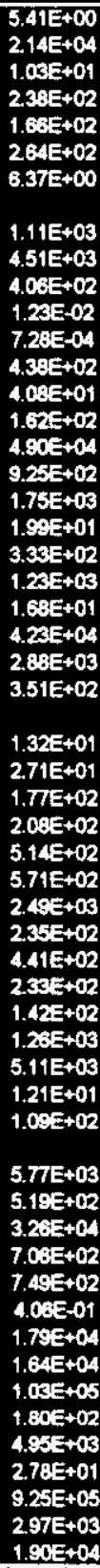 \\
\hline
\end{tabular}


WHC-SD-WM-ES-370 • Revision 0

HWW and LWW lnventovies after No Waches (Decant Only)

\begin{tabular}{|c|c|c|c|}
\hline Pin & Scinter & 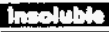 & $T 0$ \\
\hline 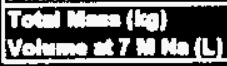 & $\begin{array}{l}25:=+03 \\
4.61 E+05\end{array}$ & $\begin{array}{l}1.75=03 \\
1.08=00\end{array}$ & $\begin{array}{l}2805+03 \\
4.58=005\end{array}$ \\
\hline 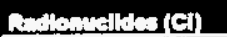 & & & \\
\hline 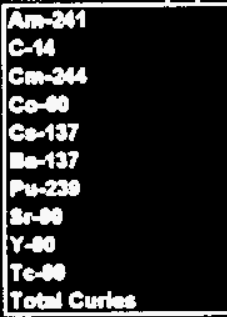 & $\begin{array}{l}.51 E+01 \\
3.16 E+01 \\
1.32 E+\infty 0 \\
2.72 E+\infty 0 \\
8.84 E+05 \\
8.40 E+06 \\
1.14 E+02 \\
2.27 E+04 \\
2.27 E+04 \\
1.11 E+02 \\
1.77 E+03\end{array}$ & $\begin{array}{l}1.19 E+02 \\
7.41 E-02 \\
3.32 x E+00 \\
1.75 E-01 \\
1.60 E+03 \\
1.57 E+03 \\
6.49 E+\infty \\
2.35 E+04 \\
2.35 E+04 \\
9.47 E-01 \\
5.01 E+04\end{array}$ & $\begin{array}{l}1.84 E+02 \\
3.17 E+01 \\
4.64 E+00 \\
2.90 E+00 \\
8.86 E+06 \\
8.42 E+06 \\
1.20 E+02 \\
4.62 E+04 \\
4.62 E+04 \\
1.12 E+02 \\
1.82 E+0.3\end{array}$ \\
\hline
\end{tabular}

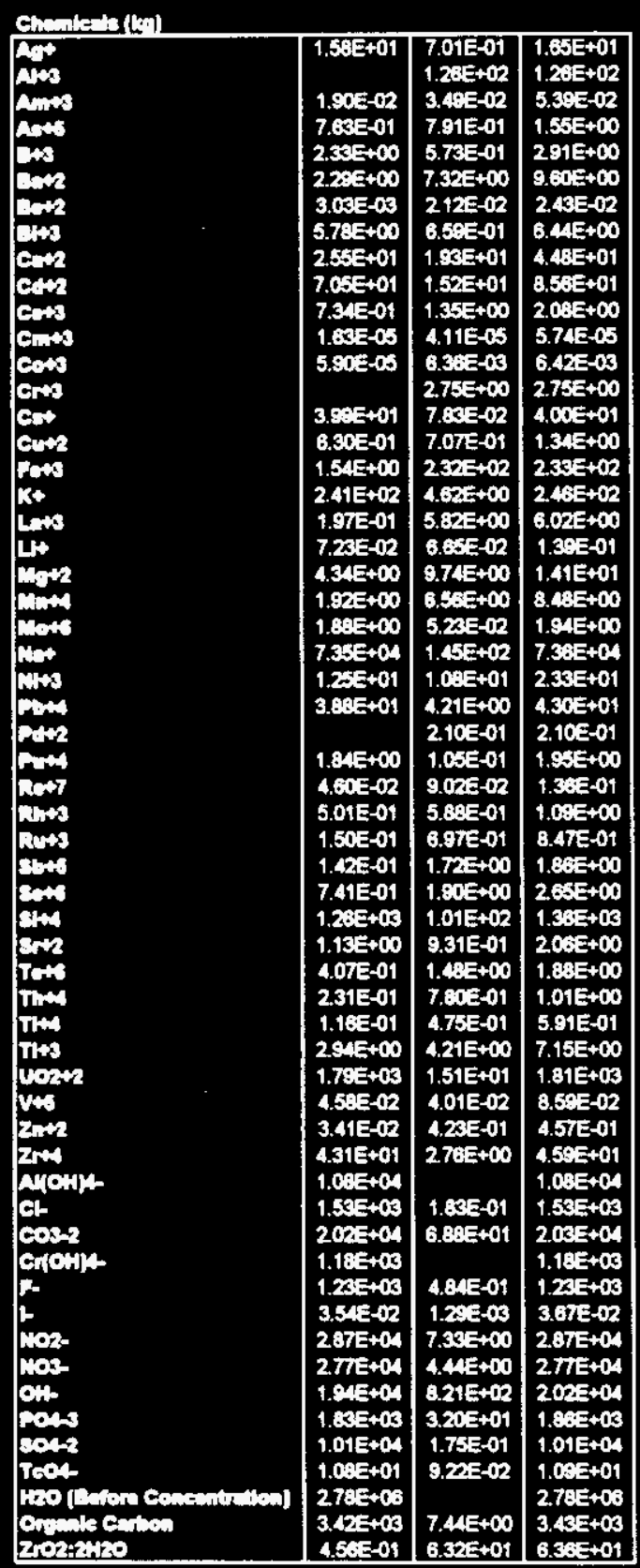


WHC-SD-WM-ES-370

Revision 0

MWW and LWW Inventories after One Dilute Caustic Wach

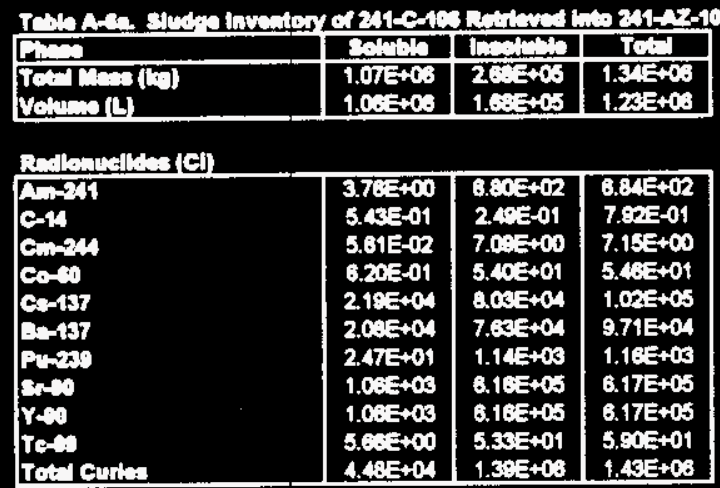

\begin{tabular}{|c|c|c|c|}
\hline Pling & 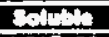 & 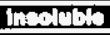 & Total \\
\hline 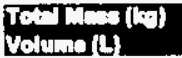 & $\begin{array}{l}1.01 E+08 \\
9.965+05\end{array}$ & $\begin{array}{l}2.55^{2}=+05 \\
1.585+05\end{array}$ & $\begin{array}{l}1.20 E+06 \\
1.15 E+06\end{array}$ \\
\hline
\end{tabular}

\begin{tabular}{|c|c|c|c|}
\hline 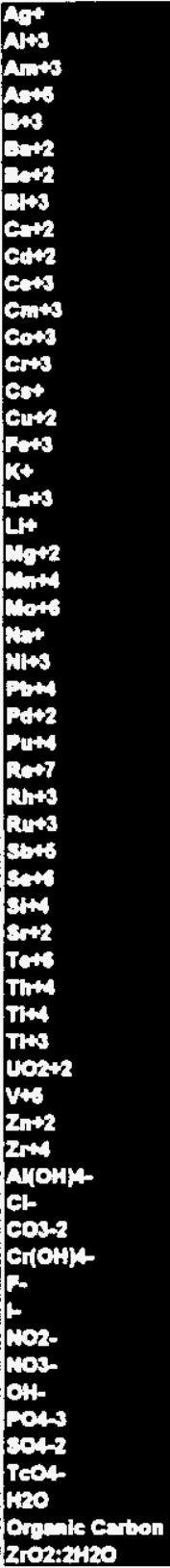 & 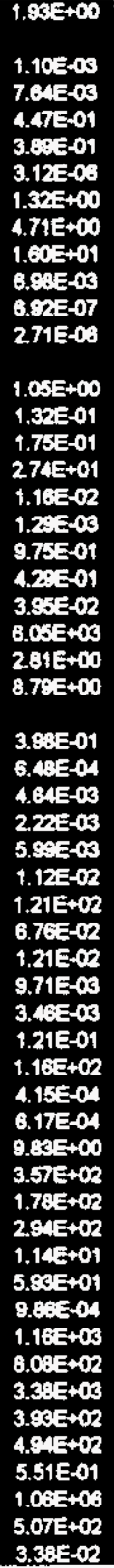 & 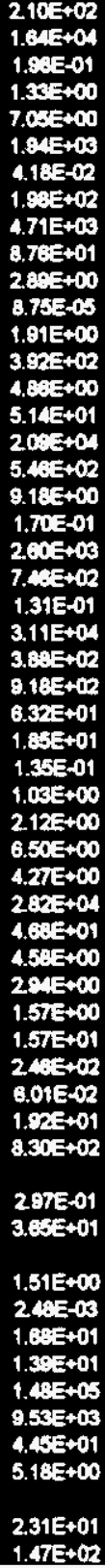 & 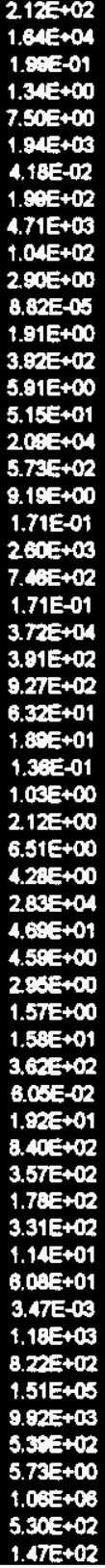 \\
\hline
\end{tabular}

\begin{tabular}{|c|c|c|c|}
\hline 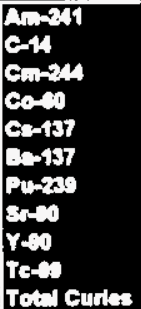 & $\begin{array}{l}8.10 E+00 \\
4.87 E+\infty 0 \\
1.75 E-01 \\
1.32 E+05 \\
1.25 E+\infty 5 \\
9.60 E-01 \\
3.02 E+03 \\
3.02 E++03 \\
1.43 E+01 \\
2.62 E+05\end{array}$ & $\begin{array}{l}3.53 E+01 \\
2.20 E+01 \\
9.94 E+02 \\
\\
4.17 E+05 \\
3.96 E+05 \\
8.08 E+02 \\
6.43 E+06 \\
6.43 E+06 \\
2.32 E+02 \\
1.37 E+07\end{array}$ & $\begin{array}{l}3.53 \mathrm{E}+04 \\
2.69 E+01 \\
9.94 \mathrm{E}+02 \\
\\
5.49 E+05 \\
5.21 \mathrm{E}+05 \\
8.10 \mathrm{E}+02 \\
6.43 \mathrm{E}+08 \\
6.43 \mathrm{E}+06 \\
2.46 \mathrm{E}+02 \\
1.40 \mathrm{E}+07\end{array}$ \\
\hline
\end{tabular}

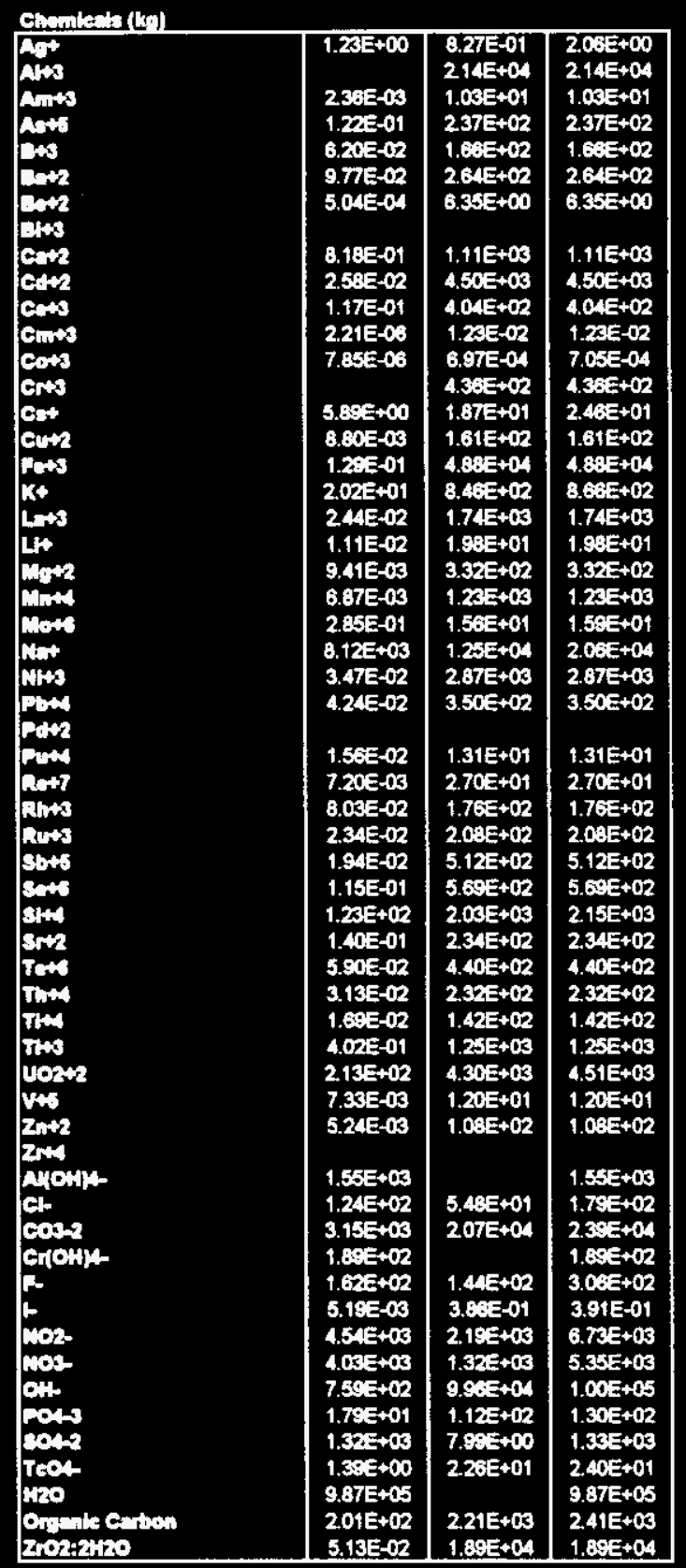


WHC-SD-WM-ES-370

Revision 0

MW and LW Inventorics aftor Ons Dilute Cauatic Wach

\begin{tabular}{|c|c|c|c|}
\hline Cos & Santers & Elacinge & $T C$ \\
\hline 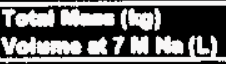 & $\begin{array}{l}8.48:=00 \\
6.88=+06\end{array}$ & $\begin{array}{l}3.46 E+03 \\
2.185+03\end{array}$ & $\begin{array}{l}8.40+0.3 \\
0.20=+06\end{array}$ \\
\hline 데 & & & \\
\hline 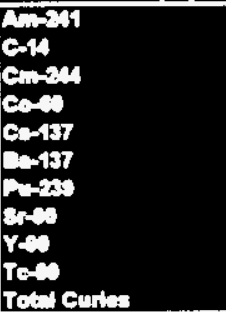 & $\begin{array}{l}9.63 E+01 \\
4.62 E+01 \\
1.86 E+00 \\
4.26 E+00 \\
1.30 E+03 \\
1.23 E+03 \\
1.78 E+02 \\
3.38 E+04 \\
3.38 E+04 \\
1.64 E+02 \\
2.60 E+06\end{array}$ & $\begin{array}{l}2.3 E E+02 \\
1.48 E-01 \\
6.65 E+00 \\
3.58 E-01 \\
3.30 E+03 \\
3.14 E+03 \\
1.30 E+01 \\
4.67 E+04 \\
4.67 E+04 \\
1.89 E+00 \\
1.00 E+05\end{array}$ & $\begin{array}{l}3.35 E+02 \\
4.64 E+01 \\
8.56 E+00 \\
4.62 E+00 \\
1.30 E+03 \\
1.24 E+03 \\
1.91 E+02 \\
8.03 E+04 \\
8.03 E+04 \\
1.63 E+02 \\
2.70 E+03\end{array}$ \\
\hline
\end{tabular}

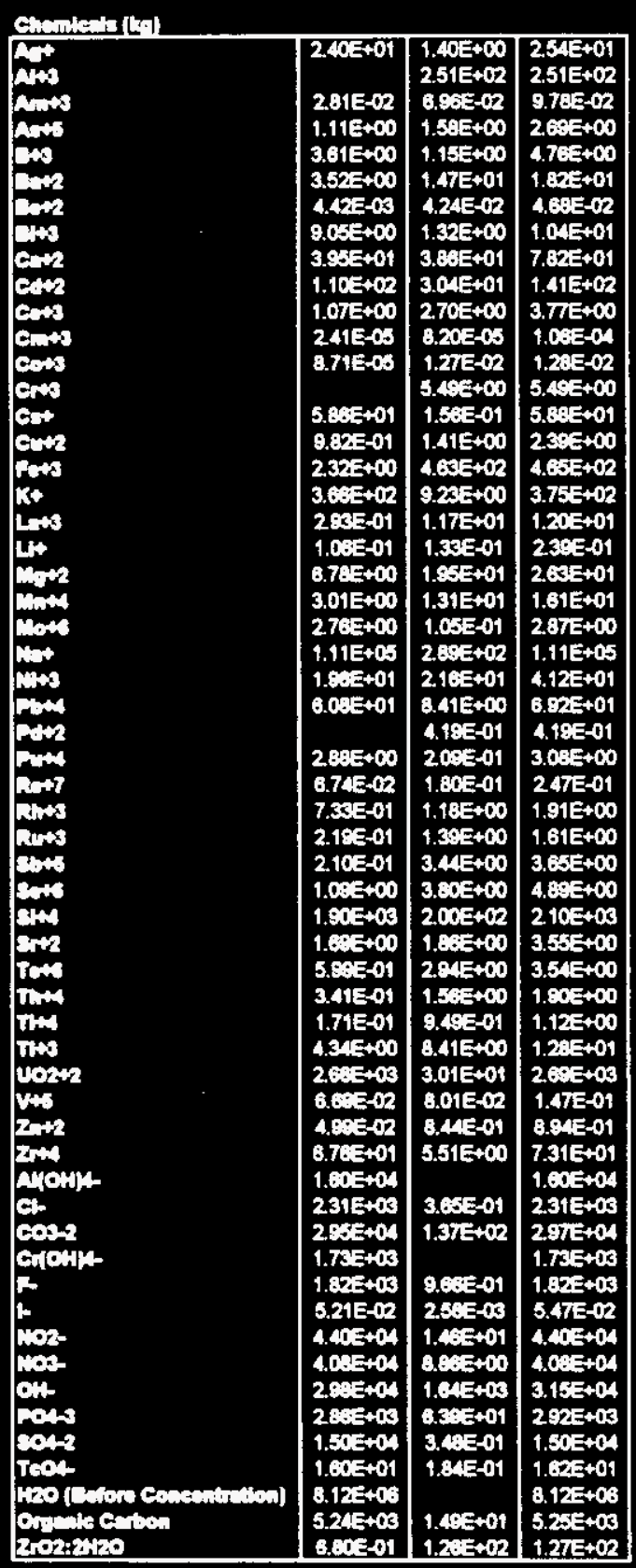


WHC-SD-WM-ES-370

Revision 0

HLW and LWW Lwentories after Two Bilute Caustic Waches

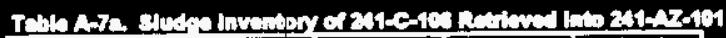

\section{Ming}

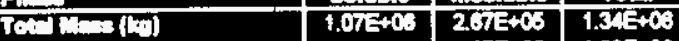

Velent:

mentos

\begin{tabular}{|c|c|c|c|}
\hline 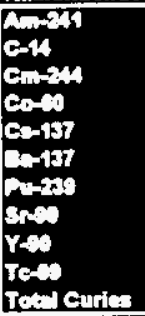 & $\begin{array}{l}1.02 E+\infty 0 \\
1.50 E-01 \\
1.61 E-02 \\
1.78 E-01 \\
6.27 E+03 \\
5.96 E+00 \\
7.06 E+00 \\
3.08 E+02 \\
3.08 E+02 \\
1.62 E+00 \\
1.23 E+04\end{array}$ & $\begin{array}{l}8.70 E+02 \\
2.48 E-01 \\
7.07 E+00 \\
5.39 E+01 \\
8.00 E+04 \\
7.60 E+04 \\
1.14 E+03 \\
6.14 E+05 \\
6.14 E+05 \\
5.31 E+01 \\
1.39 E+03\end{array}$ & $\begin{array}{l}6.78 E+02 \\
4.04 E-01 \\
7.00 E+00 \\
5.40 E+01 \\
8.65 E+04 \\
8.20 E+04 \\
1.15 E+03 \\
6.14 E+05 \\
6.14 E+06 \\
5.47 E+01 \\
1.40 E+06\end{array}$ \\
\hline
\end{tabular}

Chemilent: (th)

\begin{tabular}{|c|c|c|c|}
\hline 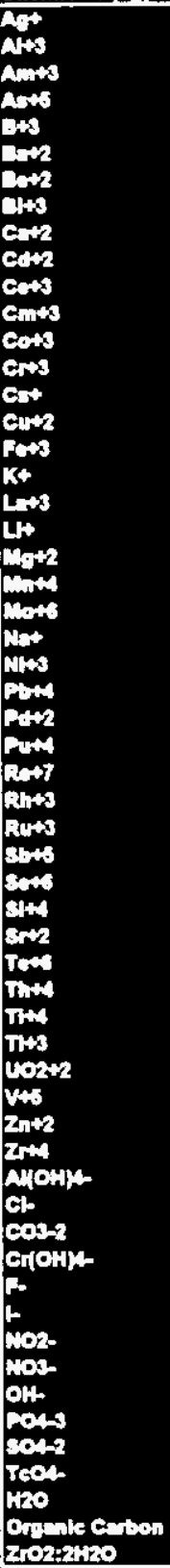 & 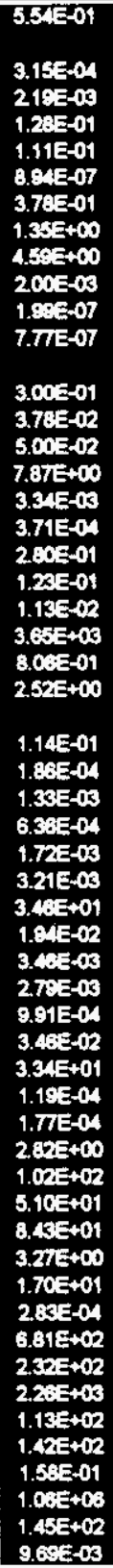 & 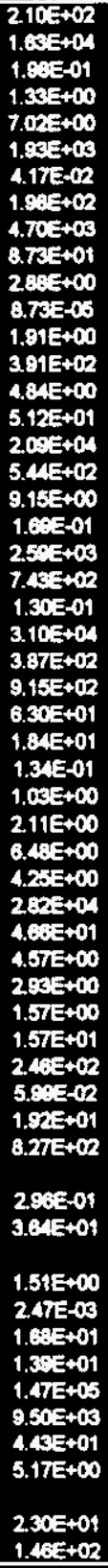 & 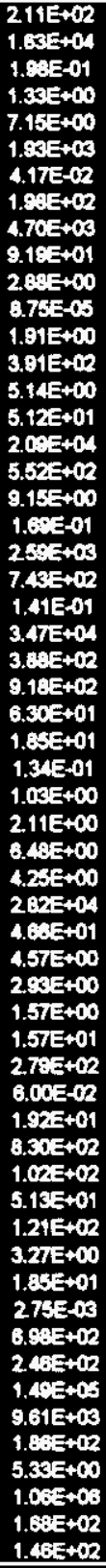 \\
\hline
\end{tabular}

\begin{tabular}{|c|c|c|c|}
\hline Pres & Salde & 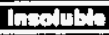 & Te:-1 \\
\hline 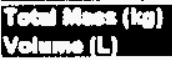 & $\begin{array}{l}1.01 E+03 \\
1.00 .=03\end{array}$ & $\begin{array}{l}2.585+00 \\
1.585+06\end{array}$ & $\begin{array}{l}1.2: \div=+03 \\
1.10 \div 5+03\end{array}$ \\
\hline
\end{tabular}

\begin{tabular}{|c|c|c|c|}
\hline 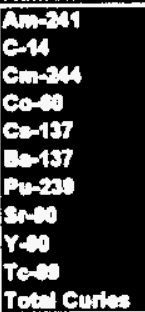 & $\begin{array}{l}2.8 E+00 \\
1.31 E+00 \\
4.83 E-02 \\
3.65 E+04 \\
3.37 E+04 \\
2.61 E-01 \\
8.14 E+02 \\
8.14 E+02 \\
3.68 E+00 \\
7.09 E+04\end{array}$ & $\begin{array}{l}3.52 E+04 \\
2.20 E+01 \\
9.91 E+02 \\
4.1 E E+05 \\
3.95 E+06 \\
8.0 E E+02 \\
6.41 E+06 \\
6.41 E+06 \\
2.31 E+02 \\
1.37 E+07\end{array}$ & $\begin{array}{l}3.52 E+04 \\
233 E+01 \\
9.91 E+02 \\
4.52 E+05 \\
4.23 E+05 \\
8.06 E+02 \\
6.41 E+06 \\
6.41 E+06 \\
2.35 E+02 \\
1.38 E+07\end{array}$ \\
\hline
\end{tabular}

\begin{tabular}{|c|c|c|c|}
\hline 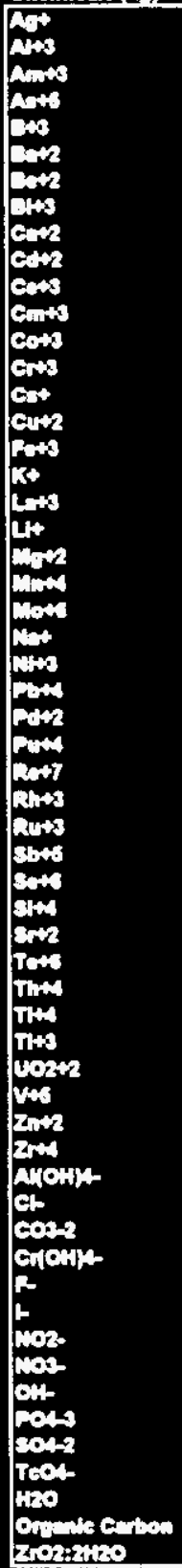 & 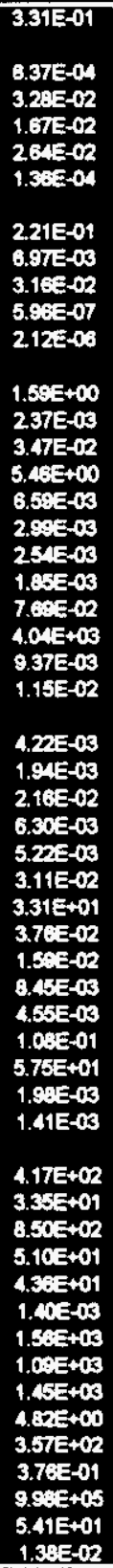 & $\begin{array}{l}8.25 E=01 \\
2.13 E+04 \\
1.05 E+01 \\
2.36 E+02 \\
1.65 E+02 \\
2.68 E+02 \\
6.38 E+00 \\
1.10 E+03 \\
4.48 E+03 \\
4.03 E+02 \\
1.22 E-02 \\
6.95 E-04 \\
4.35 E+02 \\
1.87 E+01 \\
1.61 E+02 \\
4.87 E+01 \\
8.44 E+02 \\
1.74 E+03 \\
1.96 E+01 \\
3.31 E+02 \\
1.22 E+003 \\
1.56 E+01 \\
1.26 E+04 \\
2.88 E+03 \\
3.49 E+02 \\
1.30 E+01 \\
2.70 E+01 \\
1.75 E+02 \\
2.07 E+02 \\
5.11 E+02 \\
5.67 E+02 \\
2.025+03 \\
2.35 E+02 \\
4.39 E+02 \\
2.31 E+02 \\
1.41 E+02 \\
1.25 E+03 \\
4.28 E+03 \\
1.20 E+01 \\
1.08 E+02\end{array}$ & 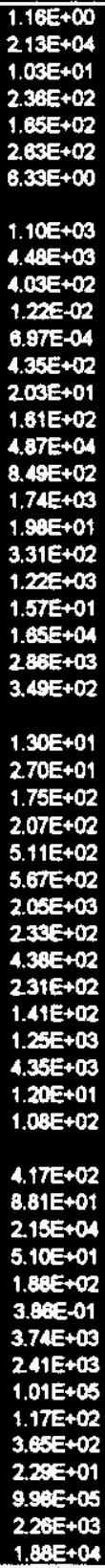 \\
\hline
\end{tabular}


WHC-SD-WM-ES-370

Revision 0

HLW and LLW Inventories after Two Dilute Caustic Waches

\begin{tabular}{|c|c|c|c|}
\hline [Fised & selnes & 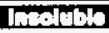 & Tound \\
\hline 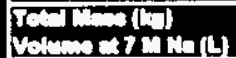 & $\begin{array}{l}1.38: 5+07 \\
8.122 E+05\end{array}$ & $\begin{array}{l}5.17 E+003 \\
3.2 x=+03\end{array}$ & $\begin{array}{l}1.3 \mathrm{SE}+07 \\
8.16 E+06\end{array}$ \\
\hline
\end{tabular}

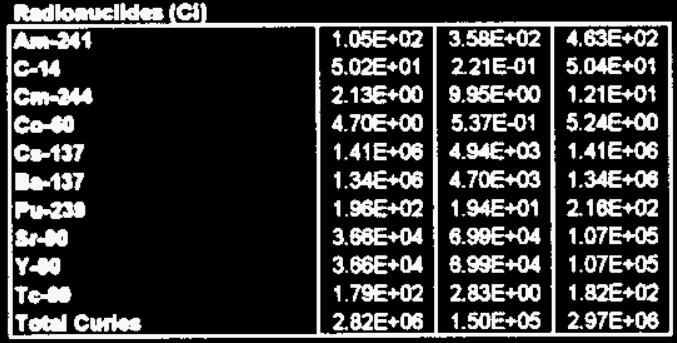

\begin{tabular}{|c|c|c|c|}
\hline 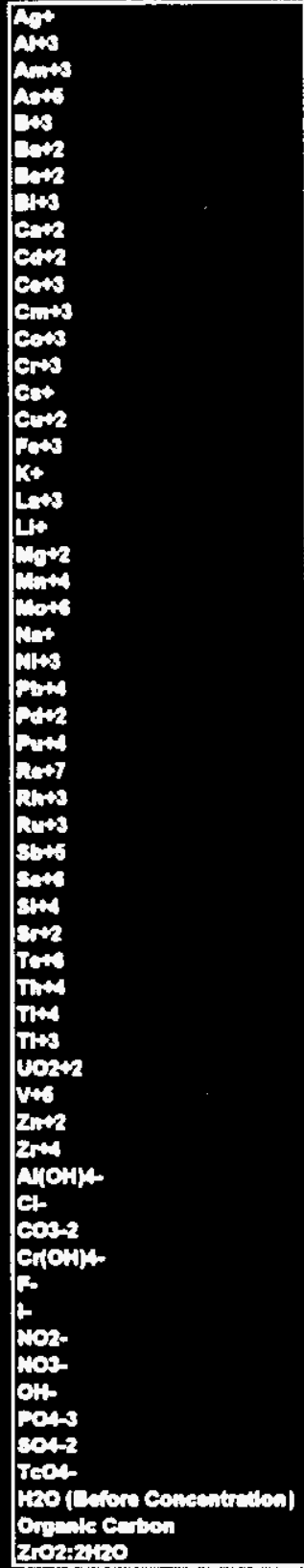 & 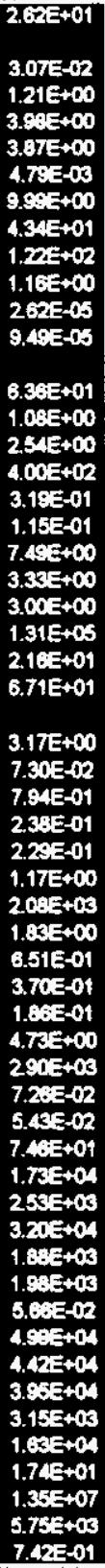 & 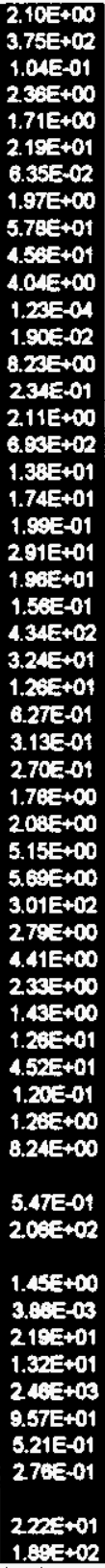 & 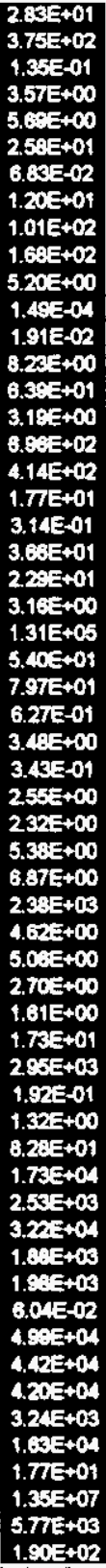 \\
\hline
\end{tabular}


WHC-SD-WM-ES-370

Revision 0

HLW and LLW Inventories after Three Dilute Caustis Washes

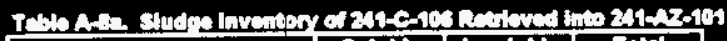
Then

\begin{tabular}{|c|c|c|c|}
\hline tor & $\begin{array}{l}1.04=60 \\
1.06=+0\end{array}$ & $200=+05$ & $\begin{array}{l}1.3 \mathrm{ME}+03 \\
1.23 \mathrm{E}+03\end{array}$ \\
\hline
\end{tabular}

Prilonutellica (C)

\begin{tabular}{|c|c|c|c|}
\hline 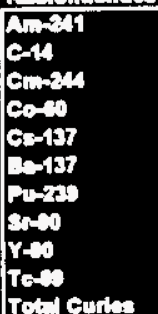 & $\begin{array}{l}3.0 E Z=01 \\
4.46 E-02 \\
4.60 E=-03 \\
5.00 E=02 \\
1.70 E+03 \\
1.70 E+03 \\
2.03 E+00 \\
8.67 E+01 \\
8.67 E+01 \\
4.64 E=01 \\
3.68 E+00\end{array}$ & 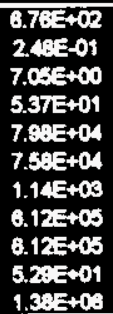 & $\begin{array}{l}6.7 E E+02 \\
283 E-01 \\
7.06 E+00 \\
5.38 E+01 \\
8.16 E+04 \\
7.75 E+04 \\
1.16 E+03 \\
6.12 E+05 \\
6.12 E+05 \\
5.34 E+01 \\
1.38 E+03\end{array}$ \\
\hline
\end{tabular}

Chemlents (kn)

\begin{tabular}{|c|c|c|c|}
\hline 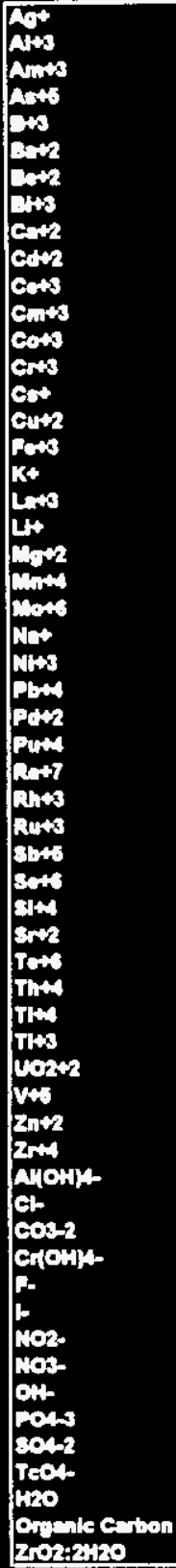 & 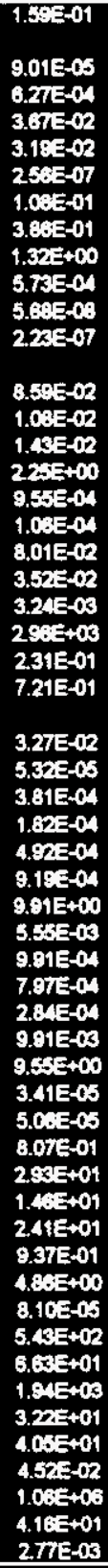 & 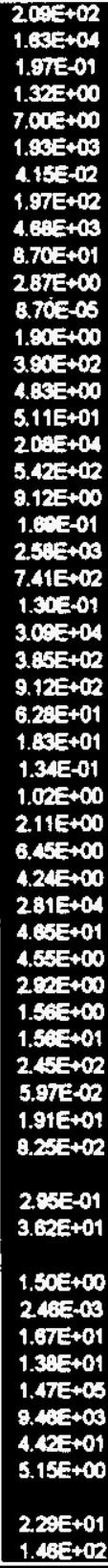 & 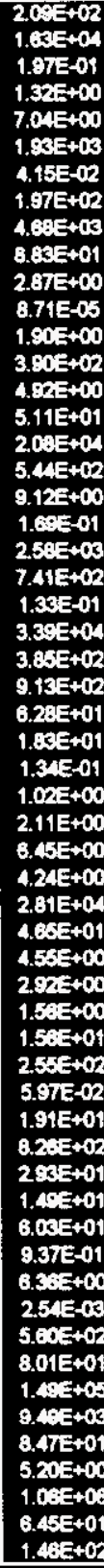 \\
\hline
\end{tabular}

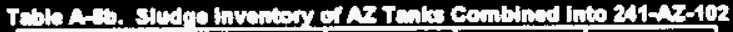

\begin{tabular}{|c|c|c|c|}
\hline Fimes & $\cos 5$ & 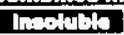 & 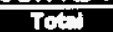 \\
\hline 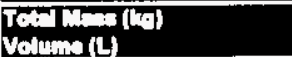 & $\begin{array}{l}1.01 E+06 \\
1.005+103\end{array}$ & $\begin{array}{l}2.51 E+0.5 \\
1.57 E+06\end{array}$ & $\begin{array}{l}1.2 \mathrm{E}+06 \\
1.16 E+06\end{array}$ \\
\hline
\end{tabular}

\begin{tabular}{|c|c|c|c|}
\hline 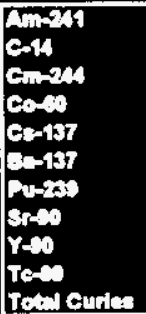 & $\begin{array}{l}5.68 E=01 \\
3.54 E-01 \\
1.30 E-02 \\
\\
9.57 E+03 \\
9.08 E+03 \\
7.05 E-02 \\
2.20 E+02 \\
2.20 E+02 \\
1.04 E+00 \\
1.91 E+04\end{array}$ & $\begin{array}{l}3.51 E+04 \\
2.19 E+01 \\
9.88 E+02 \\
\\
4.14 E+05 \\
3.94 E+05 \\
8.04 E+02 \\
6.38 E+06 \\
6.38 E+06 \\
2.30 E++02 \\
1.35 E+07\end{array}$ & $\begin{array}{l}3.51 E+04 \\
2.23 E+01 \\
9.68 E+02 \\
4.24 E+05 \\
4.03 E+05 \\
8.04 E+02 \\
6.38 E+06 \\
6.38 E+06 \\
2.31 E+02 \\
1.36 E+07 \\
\end{array}$ \\
\hline
\end{tabular}

\begin{tabular}{|c|c|c|c|}
\hline 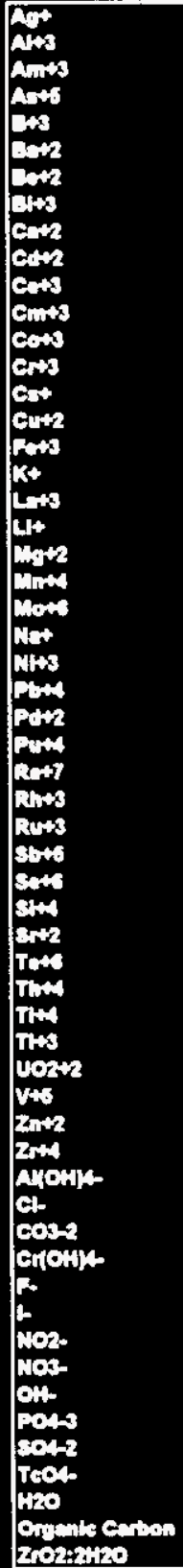 & 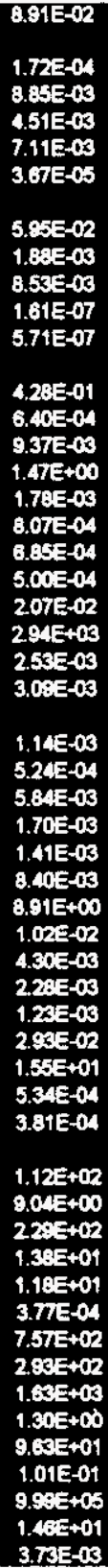 & $\begin{array}{l}8.22 E=01 \\
2.12 E+04 \\
1.02 E+01 \\
235 E+02 \\
1.65 E+02 \\
2.82 E+02 \\
8.31 E+00 \\
1.10 E+03 \\
4.47 E+03 \\
4.02 E+02 \\
1.22 E-02 \\
6.92 E-04 \\
4.33 E+02 \\
1.88 E+01 \\
1.60 E+02 \\
4.85 E+04 \\
8.41 E+02 \\
1.73 E+03 \\
1.97 E+01 \\
3.30 E+02 \\
1.22 E+03 \\
1.55 E+01 \\
1.25 E+04 \\
2.85 E+03 \\
3.48 E+02 \\
1.30 E+01 \\
2.69 E+01 \\
1.75 E+02 \\
2.06 E+02 \\
5.09 E+02 \\
5.65 E+02 \\
2.01 E+03 \\
2.32 E+02 \\
4.37 E+02 \\
2.30 E+02 \\
1.41 E+02 \\
1.25 E+03 \\
4.27 E+03 \\
1.19 E+01 \\
1.07 E+02 \\
\\
5.44 E+01 \\
2.06 E+04 \\
1.43 E+02 \\
3.84 E=01 \\
2.17 E+03 \\
1.31 E+03 \\
9.89 E+04 \\
1.12 E+02 \\
7.94 E+00 \\
2.24 E+01 \\
2.20 E+03 \\
1.88 E+04 \\
\end{array}$ & $\begin{array}{l}9.11 E-01 \\
2.12 E+04 \\
1.02 E+01 \\
2.35 E+02 \\
1.65 E+02 \\
2.62 E+02 \\
6.31 E+00 \\
1.10 E+03 \\
4.47 E+03 \\
4.02 E+02 \\
1.22 E-02 \\
6.93 E-04 \\
4.33 E+02 \\
1.36 E+01 \\
1.60 E+02 \\
4.85 E+04 \\
8.42 E+02 \\
1.73 E+03 \\
1.97 E+01 \\
3.30 E+02 \\
1.22 E+03 \\
1.55 E+01 \\
1.54 E+04 \\
2.85 E+03 \\
3.48 E+02 \\
1.30 E+01 \\
2.68 E+01 \\
1.75 E+02 \\
2.05 E+02 \\
5.08 E+02 \\
5.65 E+02 \\
2.02 E+03 \\
2.32 E+02 \\
4.37 E+02 \\
2.30 E+02 \\
1.41 E+02 \\
1.25 E+03 \\
4.20 E+03 \\
1.19 E+01 \\
1.07 E+02 \\
1.12 E+02 \\
8.34 E+01 \\
2.08 E+04 \\
1.38 E+01 \\
1.56 E+02 \\
3.84 E-01 \\
2.93 E+03 \\
1.60 E+03 \\
1.01 E+05 \\
1.13 E+02 \\
1.04 E+02 \\
2.25 E+01 \\
9.90 E+05 \\
2.21 E+03 \\
1.88 E+04 \\
\end{array}$ \\
\hline
\end{tabular}


WHC-SD-WM-ES-370

Revision 0

HLW and LLW inventories atter Three Bilute Caustic Washes

\begin{tabular}{|c|c|c|c|}
\hline 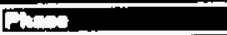 & solchele & 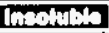 & Ter \\
\hline (W) & $\begin{array}{l}1.925+07 \\
9.085+05\end{array}$ & $\begin{array}{l}6.8 \% 5+03 \\
4.31 E+03\end{array}$ & $\begin{array}{l}1.92 E+07 \\
9.125+05\end{array}$ \\
\hline (C) & & & \\
\hline 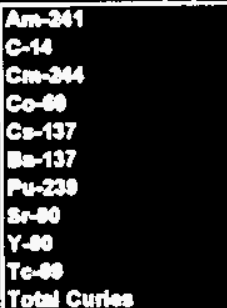 & $\begin{array}{l}1.08 E+02 \\
5.12 E+01 \\
2.17 E+00 \\
4.85 E+\infty 0 \\
1.44 E+08 \\
1.37 E+08 \\
2.01 E+02 \\
3.73 E+04 \\
3.73 E+04 \\
1.82 E+02 \\
2.8 E E+03\end{array}$ & $\begin{array}{l}4.7 E E+02 \\
2.56 E-01 \\
1.32 E+01 \\
7.14 E-01 \\
6.57 E+03 \\
6.25 E+03 \\
2.53 E+01 \\
9.32 E+04 \\
9.32 E+04 \\
3.77 E+00 \\
1.90 E+05\end{array}$ & $\begin{array}{l}5.83 E+02 \\
5.15 E+01 \\
1.54 E+01 \\
5.54 E+\infty 0 \\
1.45 E+06 \\
1.38 E+08 \\
2.27 E+02 \\
1.30 E+05 \\
1.30 E+05 \\
1.86 E+02 \\
3.09 E+06\end{array}$ \\
\hline
\end{tabular}

\begin{tabular}{|c|c|c|c|}
\hline in & 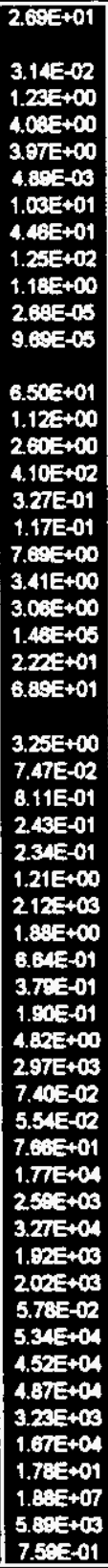 & 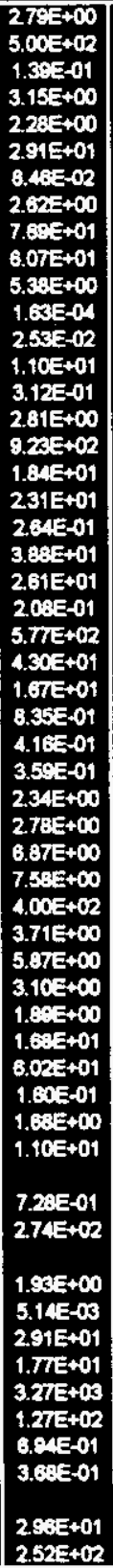 & 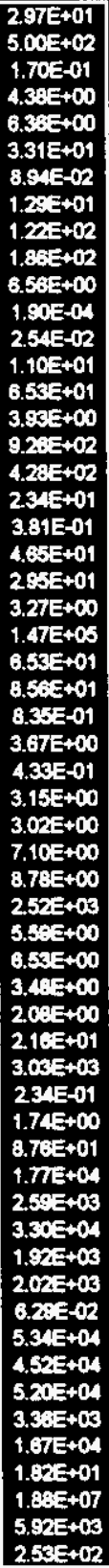 \\
\hline
\end{tabular}


HLW and LWW Inventorias after Fou Dilute Causitic Waches

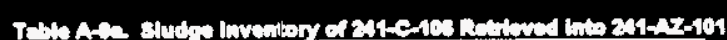

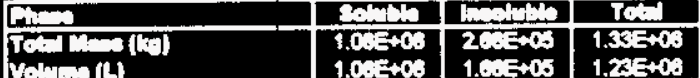

Redlonuclides (ed)

\begin{tabular}{|c|c|c|c|}
\hline 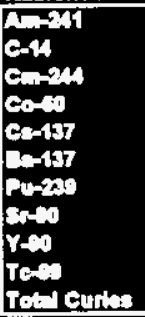 & $\begin{array}{l}8.81 E=02 \\
1.27 E-02 \\
1.31 E-01 \\
1.45 E-02 \\
5.12 E=+02 \\
4.60 E+02 \\
5.78 E-01 \\
2.48 E+01 \\
248 E+01 \\
1.32 E-01 \\
1.05 E+03\end{array}$ & $\begin{array}{l}6.75 E+02 \\
247 E-01 \\
7.02 E+00 \\
5.35 E+01 \\
7.95 E+04 \\
7.54 E+04 \\
1.13 E+03 \\
6.10 E+05 \\
6.10 E+05 \\
5.27 E+01 \\
1.38 E+03\end{array}$ & $\begin{array}{l}6.73 E+02 \\
2.60 E-01 \\
7.02 E+00 \\
5.35 E+01 \\
8.00 E+01 \\
7.00 E+04 \\
1.13 E+03 \\
6.10 E+05 \\
6.10 E+05 \\
5.28 E+01 \\
1.39 E+03\end{array}$ \\
\hline
\end{tabular}

\begin{tabular}{|c|c|c|c|}
\hline 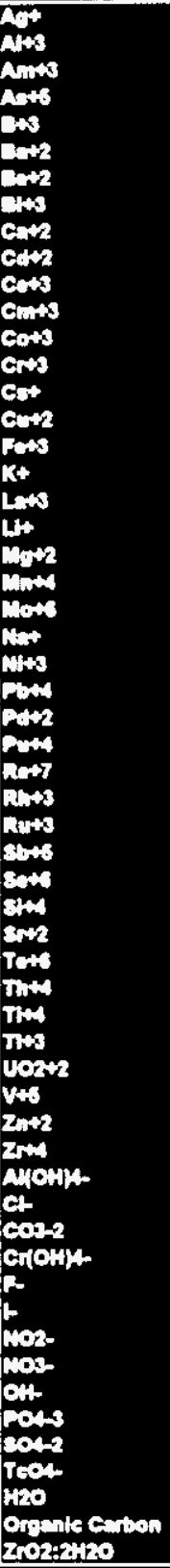 & 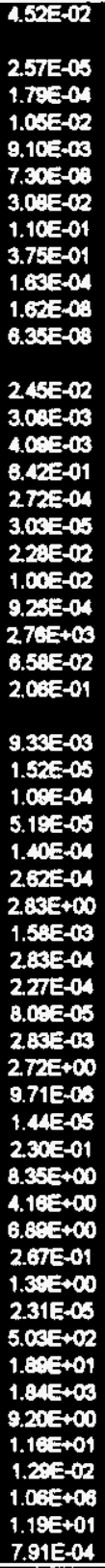 & 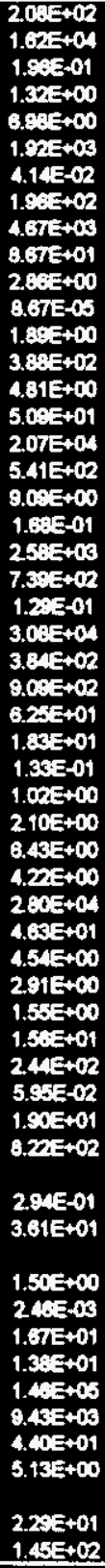 & 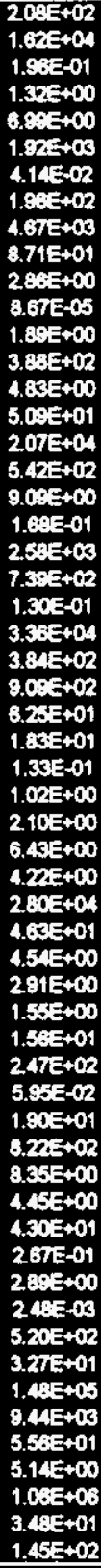 \\
\hline
\end{tabular}

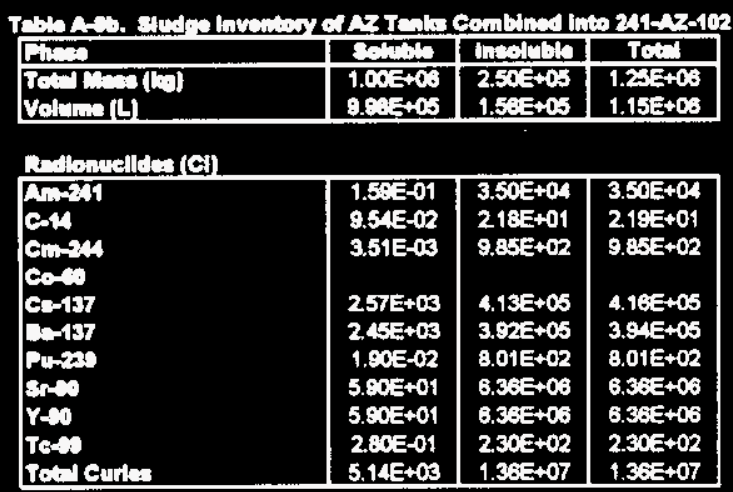

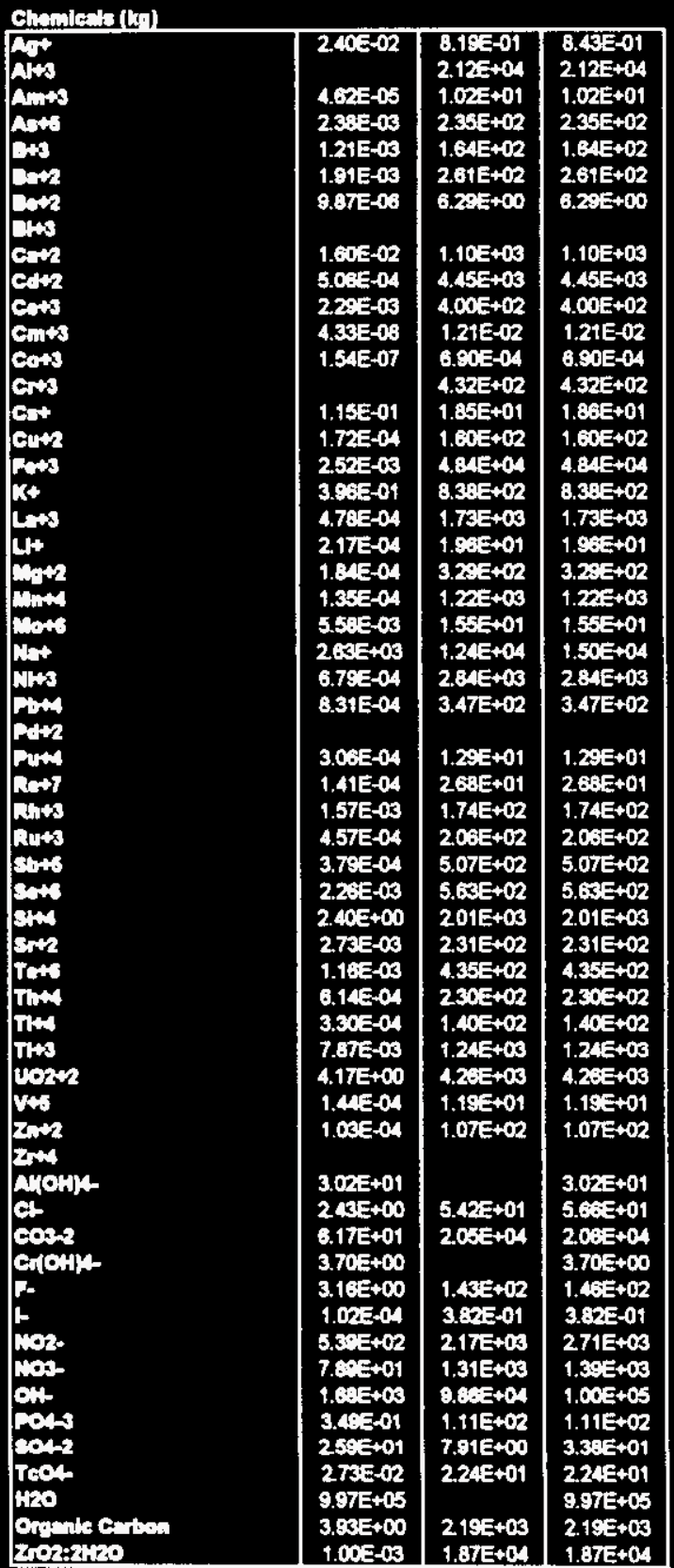


WHC-SD-WM-ES-370

Revision 0

HLW and LWW Invintories after Four Blute Caustis Washes

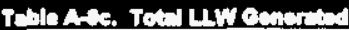

\begin{tabular}{|c|c|c|c|}
\hline 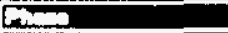 & 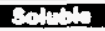 & In:cingh & 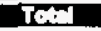 \\
\hline 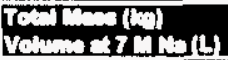 & $\begin{array}{l}2.605007 \\
9.85=00\end{array}$ & $\begin{array}{l}8.60=+03 \\
5.38=+03\end{array}$ & $\begin{array}{l}2.463=07 \\
1.00=+03\end{array}$ \\
\hline
\end{tabular}

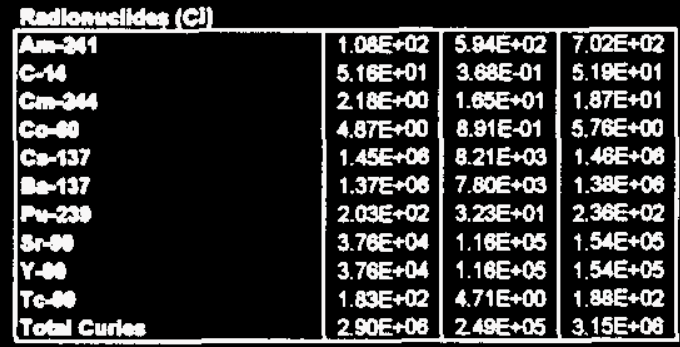

\begin{tabular}{|c|c|c|c|}
\hline (2) & 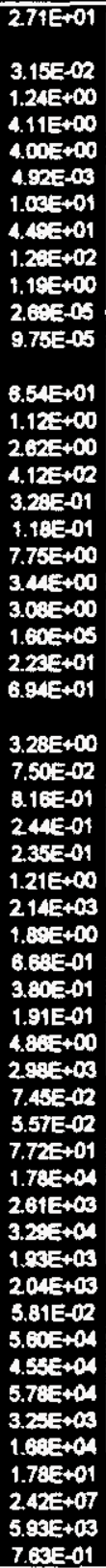 & 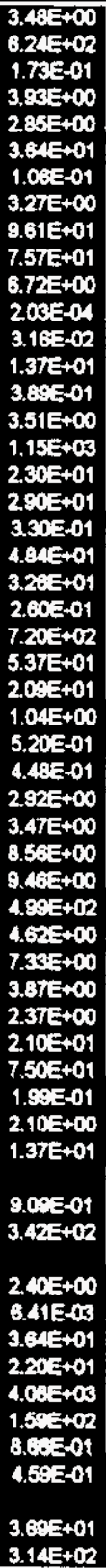 & 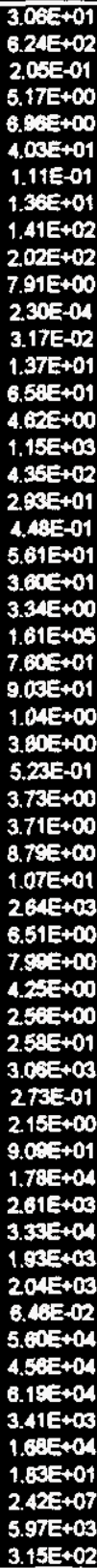 \\
\hline
\end{tabular}


HW and LW Imventories atter No Whehes (Decant Only)

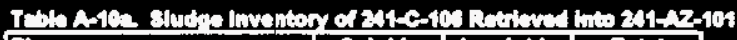

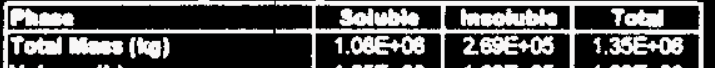

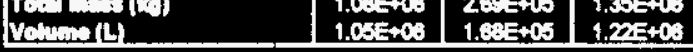

\begin{tabular}{|c|c|c|c|}
\hline 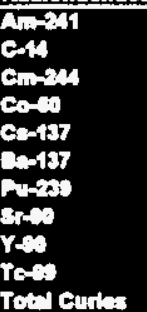 & $\begin{array}{l}1.31 E+01 \\
1.60 E+\infty 0 \\
1.80 E-01 \\
2.16 E+\infty \\
7.62 E+04 \\
7.24 E+04 \\
8.61 E+01 \\
3.60 E+03 \\
3.68 E+03 \\
1.97 E+01 \\
1.68 E+06\end{array}$ & $\begin{array}{l}6.82 E+02 \\
250 E-01 \\
7.12 E+00 \\
5.42 E+01 \\
8.05 E+04 \\
7.65 E+04 \\
1.15 E+03 \\
6.18 E+05 \\
6.18 E+05 \\
5.34 E+01 \\
1.40 E+01\end{array}$ & 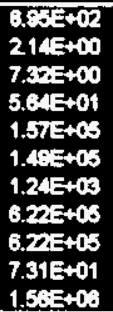 \\
\hline
\end{tabular}

\section{Cheivieats (kn)}

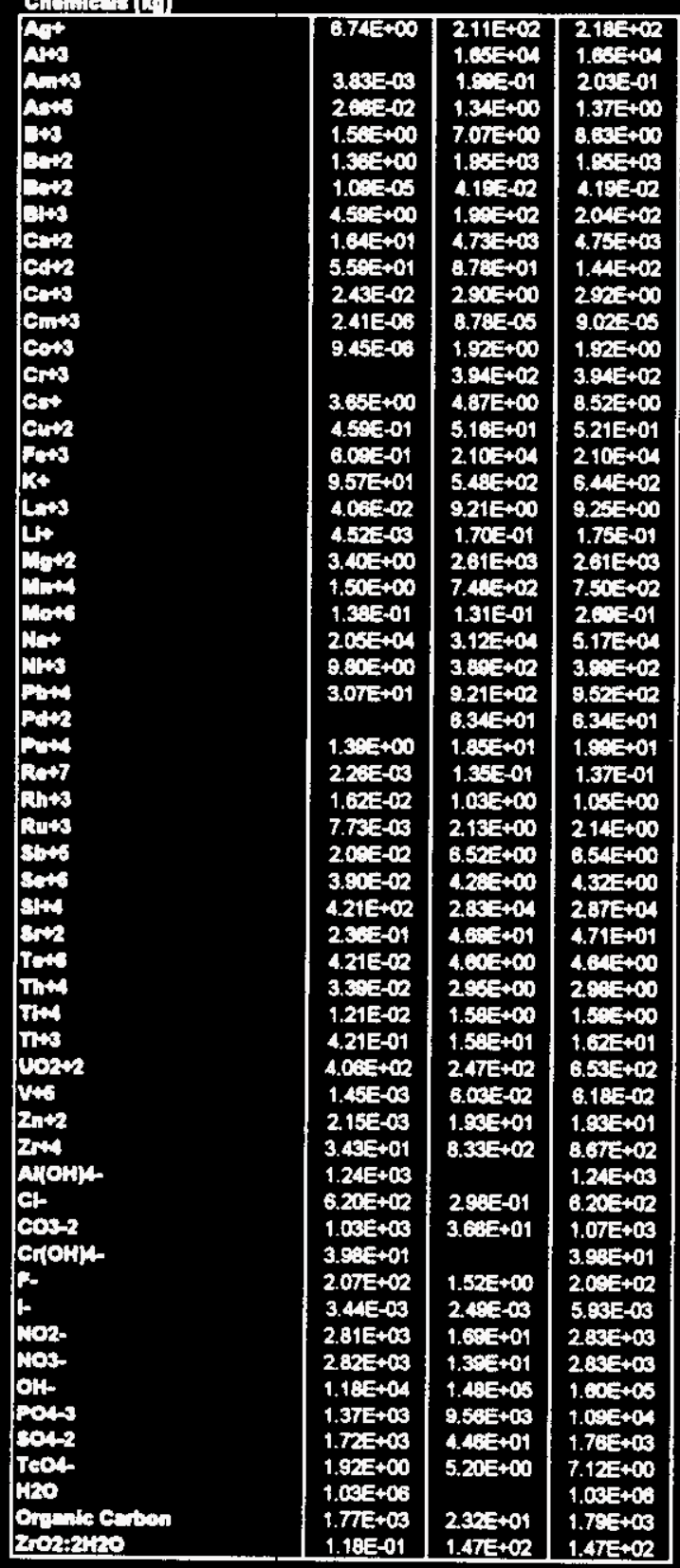

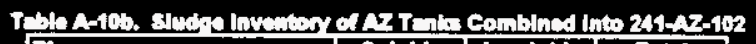

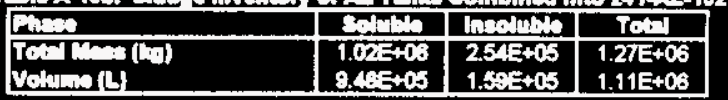

Volingl

\begin{tabular}{|c|c|c|c|}
\hline 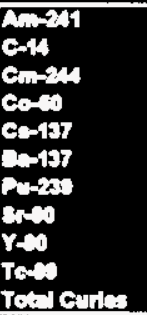 & $\begin{array}{l}3.05 E+01 \\
1.80+E+01 \\
6.60 E-01 \\
\\
4.81 E+05 \\
4.67 E+05 \\
3.62 E+\infty 0 \\
1.13 E+04 \\
1.13 E+04 \\
5.36 E+01 \\
9.00 E+05\end{array}$ & $\begin{array}{l}3.51 E+04 \\
2.21 E+01 \\
9.98 E+02 \\
4.18 E+06 \\
3.98 E+05 \\
8.12 E+02 \\
6.45 E+03 \\
6.45 E+08 \\
233 E+02 \\
1.39 E+07\end{array}$ & $\begin{array}{l}3.54 E+04 \\
4.03 E+01 \\
9.96 E+02 \\
\\
9.09 E+05 \\
8.65 E+05 \\
8.16 E+02 \\
6.46 E+06 \\
6.46 E+06 \\
2.87 E+02 \\
1.48 E+07\end{array}$ \\
\hline
\end{tabular}

comiente $(k x)$

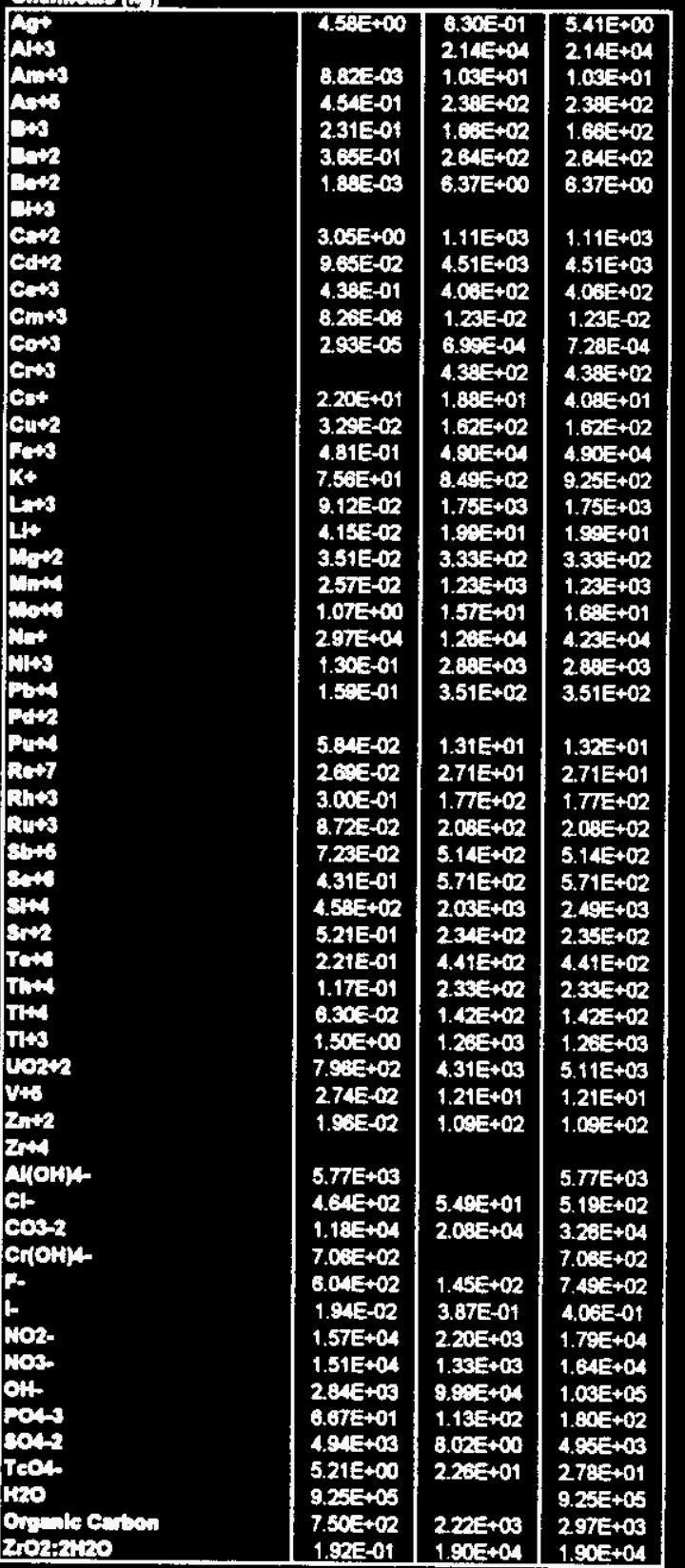


WHC-SD-WM-ES-370

Revision 0

HWW and LW inventorise after No Washes (Decant Onhy)

\begin{tabular}{|c|c|c|c|}
\hline$c=0$ & Salnes & 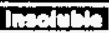 & $70 \div$ \\
\hline Volmed & $\begin{array}{l}2585+43 \\
4575+05\end{array}$ & $\begin{array}{l}1.735+03 \\
1.095+03\end{array}$ & $\begin{array}{l}25: 5+00 \\
468: 505\end{array}$ \\
\hline$(\mathrm{C})$ & & & \\
\hline 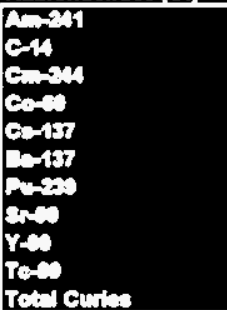 & $\begin{array}{l}8.51 E+01 \\
3.16 E+01 \\
1.37 E=00 \\
2.72 E+00 \\
8.84 E+03 \\
8.40 E+05 \\
1.14 E+02 \\
2.27 E+04 \\
2.27 E+04 \\
1.11 E+02 \\
1.77 E+03\end{array}$ & $\begin{array}{l}1.1 E z+02 \\
7.41 E-02 \\
3.32 E=+\infty 0 \\
1.7 E 5-01 \\
1.69 E+03 \\
1.67 E+03 \\
6.40 E+\infty 0 \\
2.36 E+04 \\
236 E+04 \\
9.47 E-01 \\
5.01 E+04\end{array}$ & $\begin{array}{l}1.84=+02 \\
3.17 E+01 \\
4.84=+00 \\
206=+00 \\
8.8= \pm+06 \\
8.42 E+06 \\
1.20=+02 \\
4.62=+04 \\
4.62=+04 \\
1.12=+02 \\
1.82=+03\end{array}$ \\
\hline
\end{tabular}

\begin{tabular}{|c|c|c|c|}
\hline 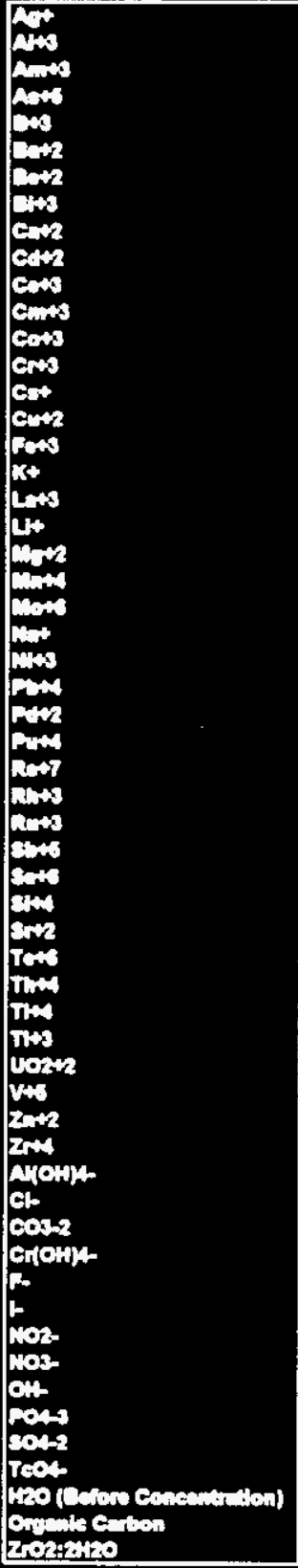 & 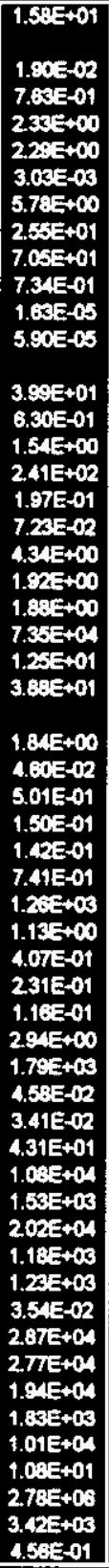 & 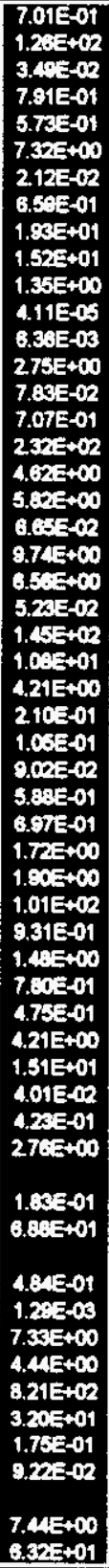 & 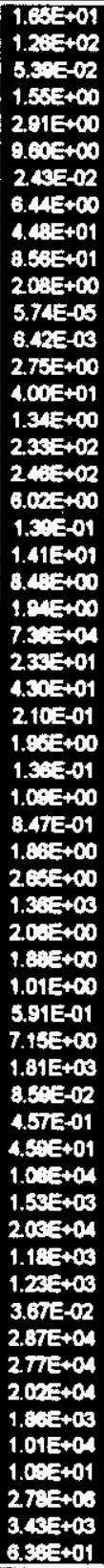 \\
\hline
\end{tabular}


HLW and LWW Inventories after Ona Caustic Wash (3 M OH.)

\begin{tabular}{|c|c|c|c|}
\hline Fines & solon & Intoriones & $T+m$ \\
\hline 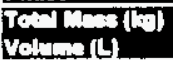 & $\begin{array}{l}8.78=+63 \\
8.89=06\end{array}$ & $\begin{array}{l}245+05 \\
1.585+05\end{array}$ & $\begin{array}{l}1.22=00 \\
1.045+03\end{array}$ \\
\hline \multicolumn{4}{|c|}{ R-diontrelldes (ej) } \\
\hline 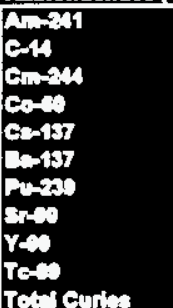 & 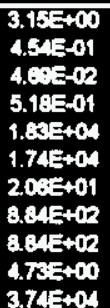 & 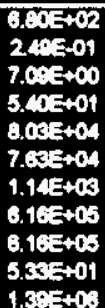 & 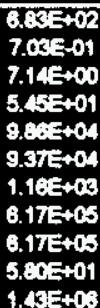 \\
\hline
\end{tabular}

\begin{tabular}{|c|c|c|c|}
\hline Den: & Solven & 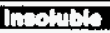 & $T+1$ \\
\hline 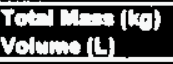 & $\begin{array}{l}7.9 .15+00 \\
7.075+06\end{array}$ & $\begin{array}{l}2.003+03 \\
1.20+06\end{array}$ & $\begin{array}{l}9.65=+05 \\
8.325+05\end{array}$ \\
\hline \multicolumn{4}{|c|}{ Rotlonuldes (C) } \\
\hline 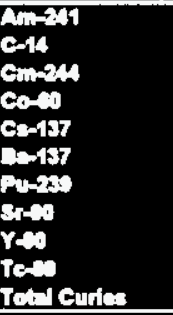 & 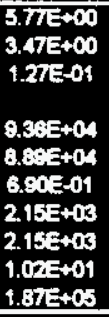 & 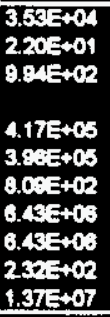 & $\begin{array}{l}3.5 E E+04 \\
2.55 E+01 \\
9.84 E+02 \\
5.11 E+06 \\
4.85 E+05 \\
8.10 E+02 \\
6.43 E+06 \\
6.45 E+06 \\
2.42 E+02 \\
1.39 E+07\end{array}$ \\
\hline
\end{tabular}

\begin{tabular}{|c|c|c|c|}
\hline 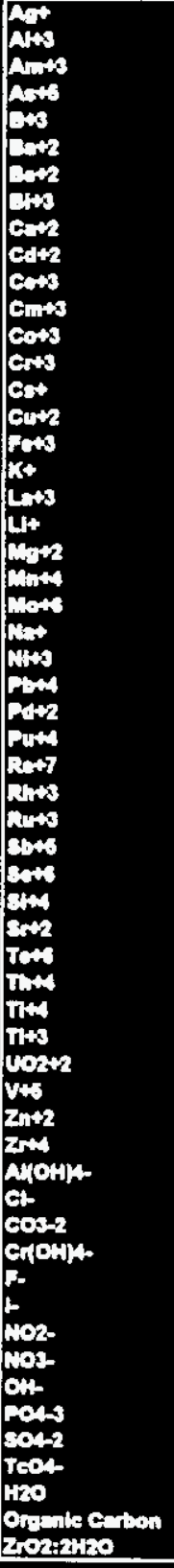 & 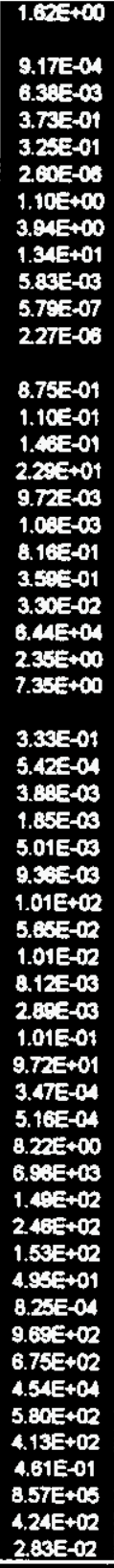 & 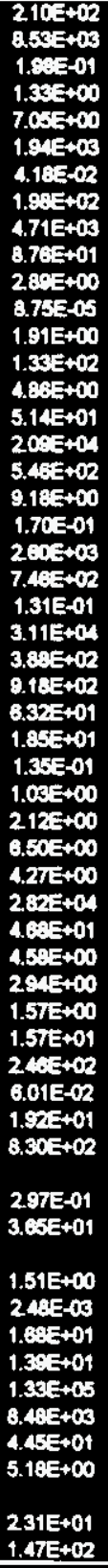 & 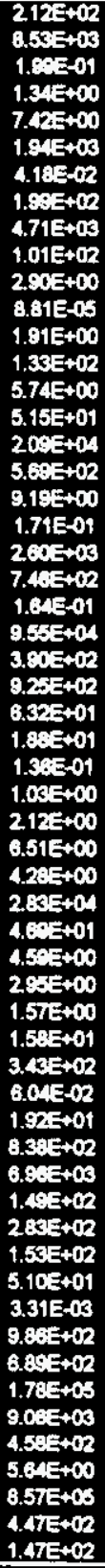 \\
\hline
\end{tabular}

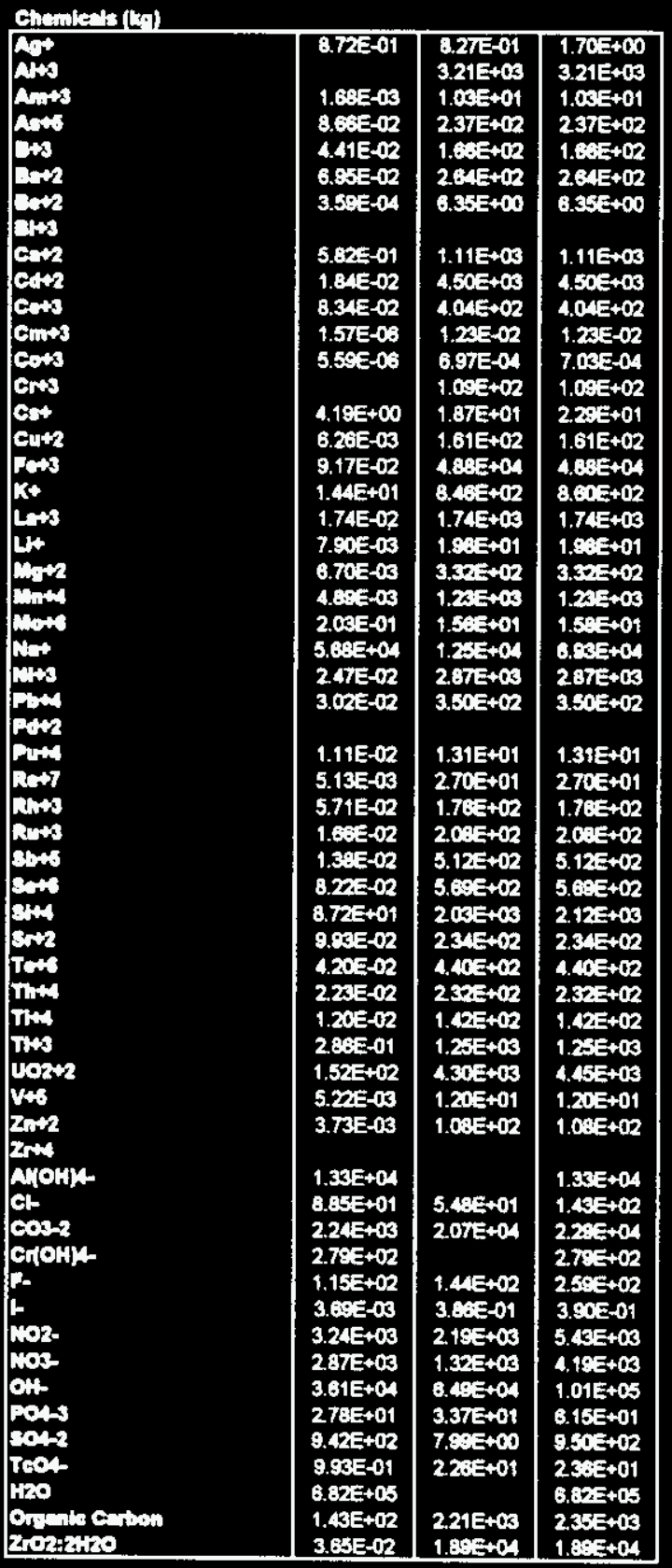


WHC-SD-WM-ES-370

Revision 0

HLW and $L W$ Inventories after One Caustic Wach (3 M OH-)

\begin{tabular}{|c|c|c|c|}
\hline Pis & Salon & 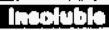 & 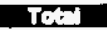 \\
\hline 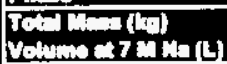 & $\begin{array}{l}8.48 E+03 \\
3.235+03\end{array}$ & $\begin{array}{l}3.20 \mathrm{E}=013 \\
2.005+03\end{array}$ & $\begin{array}{l}9.4 .5+0.6 \\
3.2 \times 5+06\end{array}$ \\
\hline \multicolumn{4}{|l|}{ Redlowellike (C) } \\
\hline 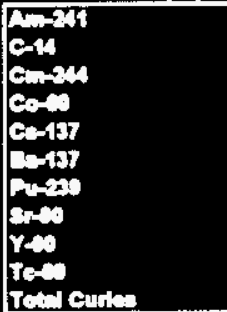 & $\begin{array}{l}9.86=+01 \\
4.77 E+01 \\
2.02 E+00 \\
4.36 E+00 \\
1.34 E+08 \\
1.23 E+08 \\
1.82 E+02 \\
3.46 E+04 \\
3.46 E+04 \\
1.60 E+02 \\
26 E=+03\end{array}$ & $\begin{array}{l}2.3 E z+02 \\
1.48 E-01 \\
6.65 E+00 \\
3.58 E-01 \\
3.30 E+03 \\
3.14 E+03 \\
1.30 E+01 \\
4.67 E+04 \\
4.67 E+04 \\
1.80 E+00 \\
1.00 E+06\end{array}$ & $\begin{array}{l}3.3 E E+02 \\
4.78 E+01 \\
8.63 E+00 \\
4.72 E+00 \\
1.36 E+00 \\
1.28 E+00 \\
1.89 E+02 \\
8.13 E+04 \\
8.13 E+04 \\
1.71 E+02 \\
2.7 E E+03\end{array}$ \\
\hline
\end{tabular}

\begin{tabular}{|c|c|c|c|}
\hline 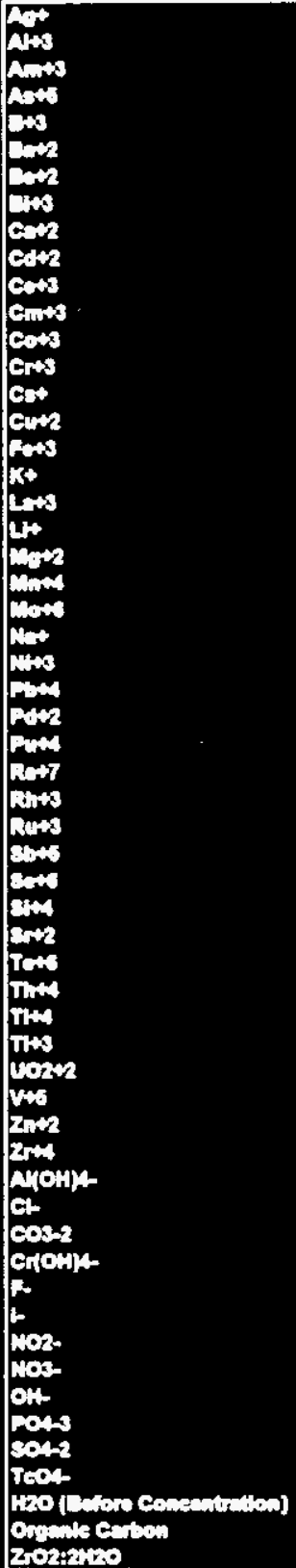 & 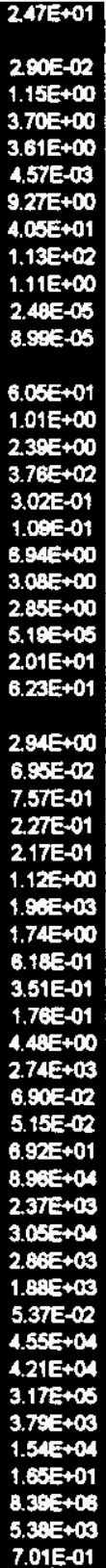 & 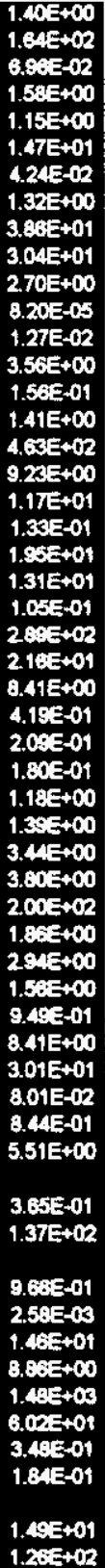 & 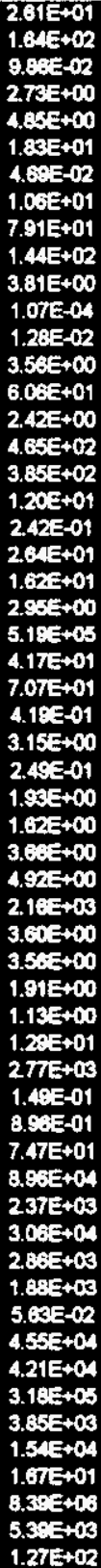 \\
\hline
\end{tabular}


HLW and LWW Inventodies ater One Caustis Woch (3 M OH-) and One Dilute Caustle Wash

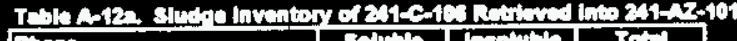

\begin{tabular}{|c|c|c|c|}
\hline $\mathrm{Pin}_{\mathrm{N}}$ & 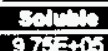 & 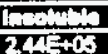 & $\frac{101}{1.2 x+63}$ \\
\hline 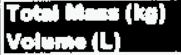 & $\begin{array}{l}9.70=+\infty \\
0.50=+\infty\end{array}$ & $\begin{array}{l}2.64+0.06 \\
1.535+06\end{array}$ & $1.105+03$ \\
\hline \multicolumn{4}{|l|}{ 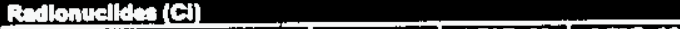 } \\
\hline 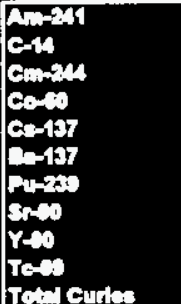 & 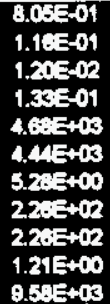 & 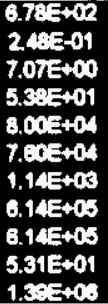 & $\begin{array}{l}8.7 E E+02 \\
3.64 E-01 \\
7.00 E+00 \\
5.30 E+01 \\
8.47 E+04 \\
8.04 E+04 \\
1.15 E+03 \\
6.14 E+06 \\
6.14 E+06 \\
5.48 E+01 \\
1.40 E+0 .\end{array}$ \\
\hline
\end{tabular}

\begin{tabular}{|c|c|c|c|}
\hline 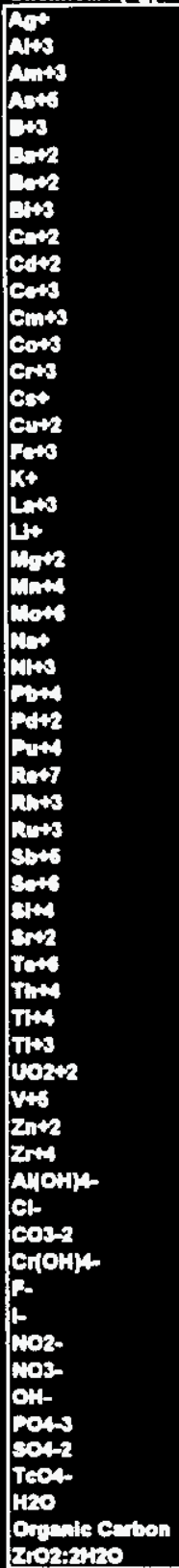 & 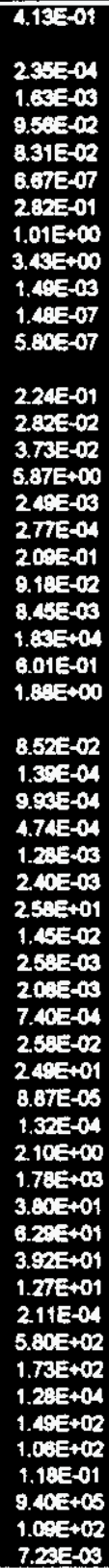 & 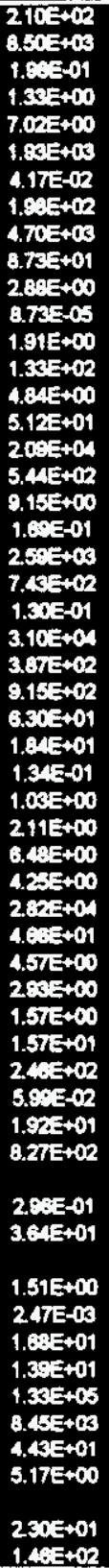 & 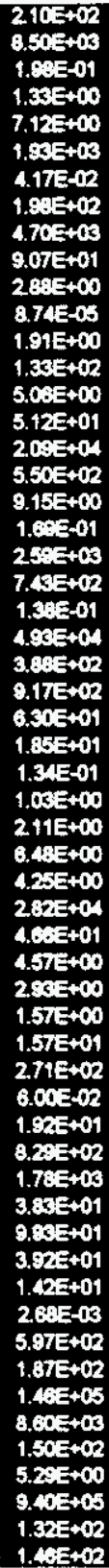 \\
\hline
\end{tabular}

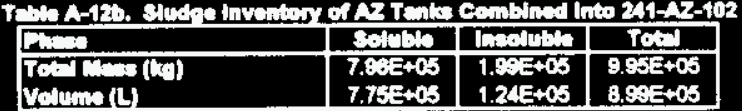

\begin{tabular}{|c|c|c|c|}
\hline 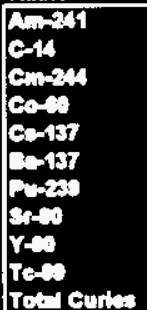 & $\begin{array}{l}1.21 E+\infty 0 \\
7.25 E-01 \\
2.68 E-02 \\
1.96 E+04 \\
1.86 E+04 \\
1.44 E-01 \\
4.48 E+02 \\
4.4 E=+02 \\
2.13 E+\infty \\
3.00=+04\end{array}$ & $\begin{array}{l}3.6 x E+04 \\
2.20 E+01 \\
9.81 E+02 \\
4.16 E+05 \\
3.96 E+05 \\
8.06 E+02 \\
6.41 E+08 \\
6.41 E+08 \\
2.31 E+02 \\
1.37 E+07\end{array}$ & $\begin{array}{l}3.52 E+04 \\
2.27 E+01 \\
9.91 E+02 \\
4.36 E+05 \\
4.14 E+05 \\
8.06 E+02 \\
6.41 E+08 \\
6.41 E+08 \\
2.33 E+02 \\
1.37 E+07\end{array}$ \\
\hline
\end{tabular}

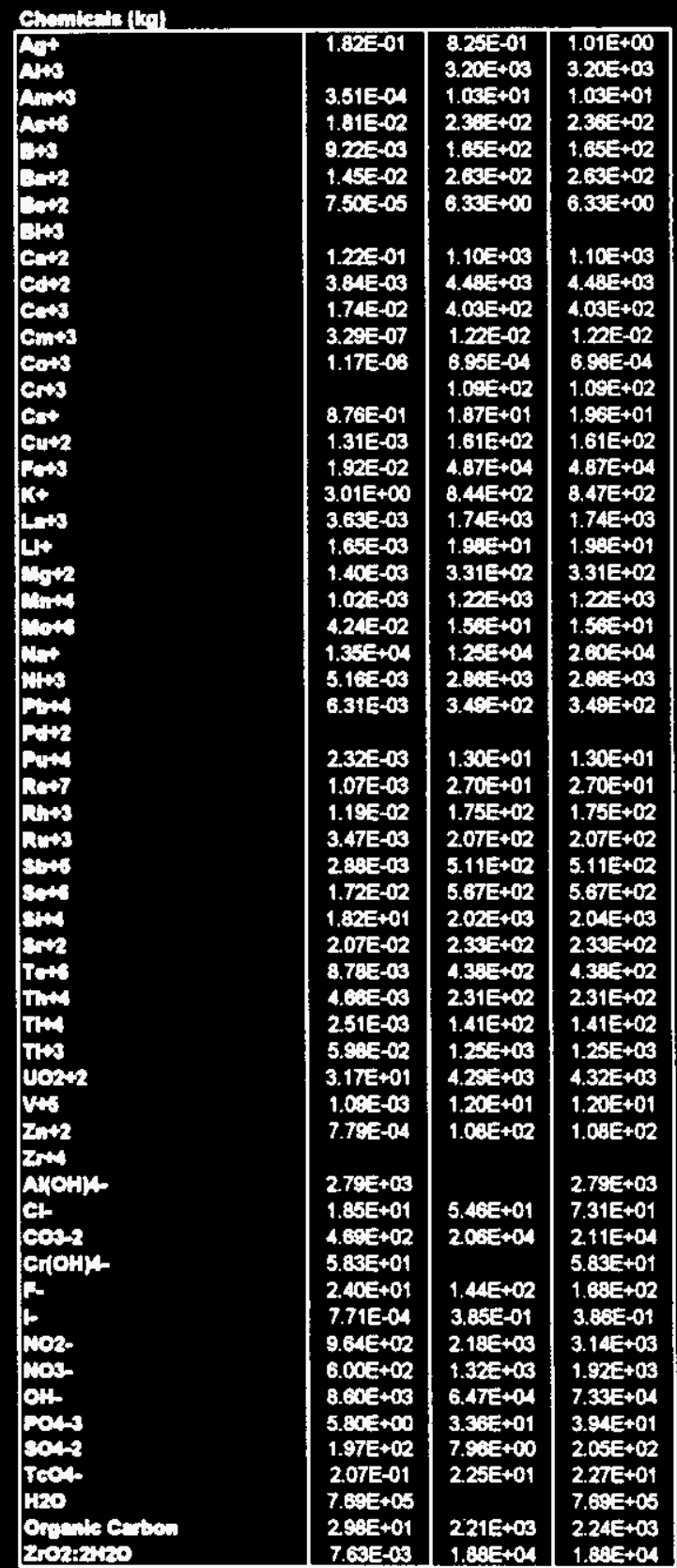


WHC-SD-WM-ES-370

Revision 0

HLW and LLW Invertories after Onv Causte Wash (3 $\mathrm{M} \mathrm{OH}$ ) and One Dilute Caustic Wash

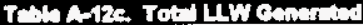

\begin{tabular}{|c|c|c|c|}
\hline $\mathrm{s}$ & Sording & In:elobelo & $T 0+1$ \\
\hline 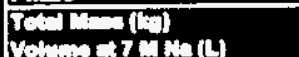 & $\begin{array}{l}1.63=+07 \\
3.07 E+03\end{array}$ & $\begin{array}{l}4.67 E+03 \\
292 E+03\end{array}$ & \\
\hline
\end{tabular}

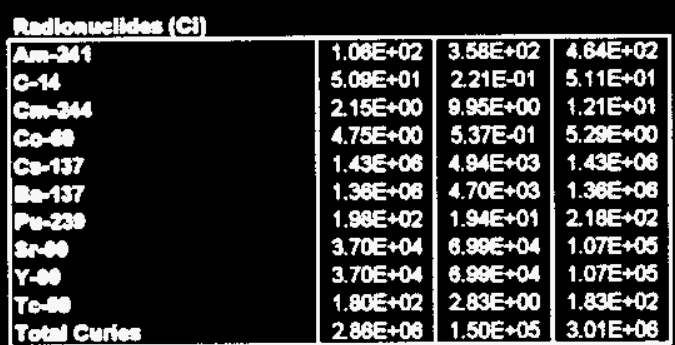

\begin{tabular}{|c|c|c|c|}
\hline 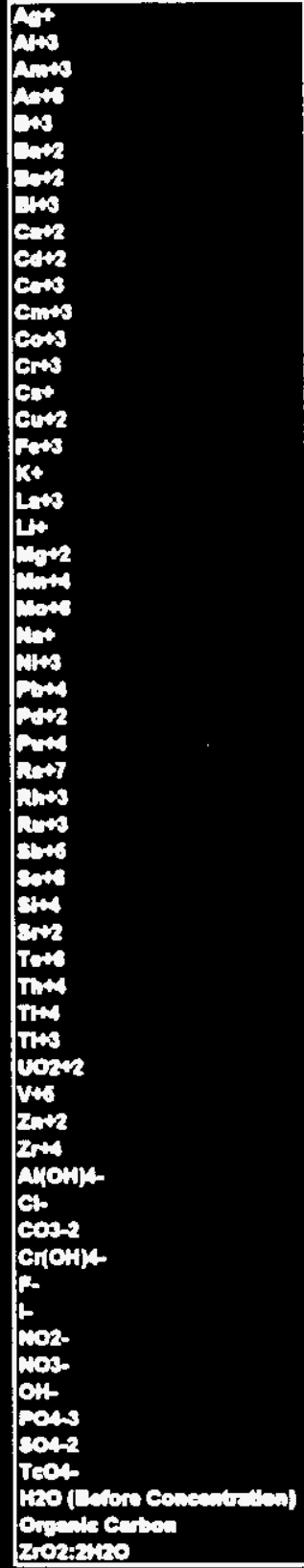 & 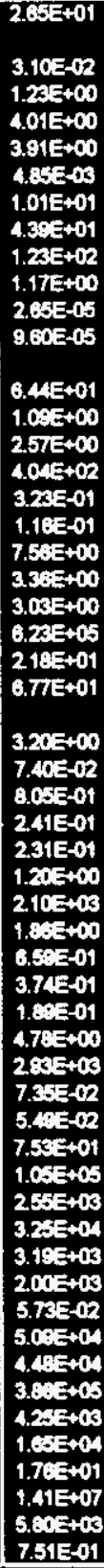 & 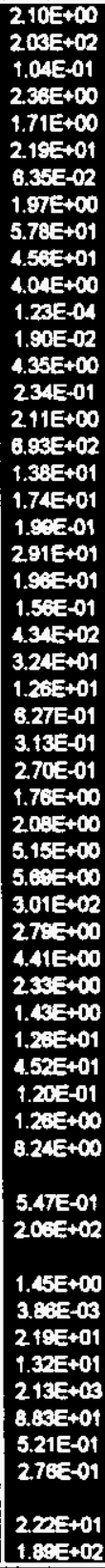 & 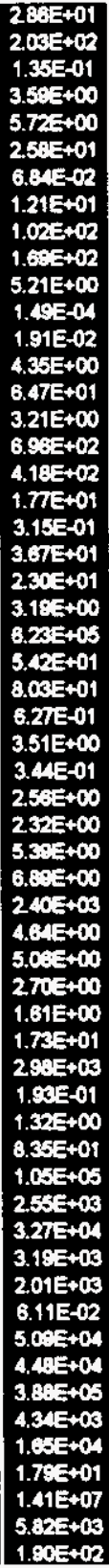 \\
\hline
\end{tabular}


WHC-SD-WM-ES-370
Revision 0

HLW and LW Inventorise aner One Caustic Wach (3 $\mathrm{M}$ OH-) and Two Dllute Caustic Washes

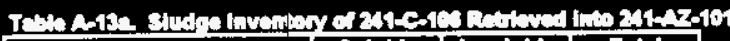

\begin{tabular}{|c|c|c|c|}
\hline Pens & Solng & 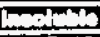 & Trin \\
\hline Vis & $\begin{array}{l}9.71 E+65 \\
8.8+1=45\end{array}$ & $\begin{array}{l}2.65+60 \\
1.54=05\end{array}$ & $\begin{array}{l}1.21 E+\infty 8 \\
1.11 E+06\end{array}$ \\
\hline A & & & \\
\hline 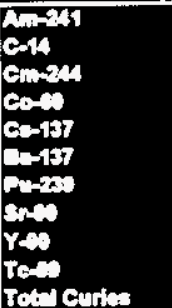 & $\begin{array}{l}200=-01 \\
3.02 E-02 \\
3.11 E-03 \\
3.44 E-02 \\
1.21 E+03 \\
1.1 E E+03 \\
1.37 E+00 \\
5.87 E+01 \\
5.87 E+01 \\
3.14 E-01 \\
24 E=+03\end{array}$ & 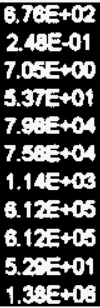 & $\begin{array}{l}6.7 E E+02 \\
2.7 E E-01 \\
7.05 E+00 \\
5.37 E+01 \\
8.10 E+04 \\
7.70 E+04 \\
1.14 E+03 \\
6.12 E+05 \\
6.12 E+05 \\
5.32 E+01 \\
1.38 E+03\end{array}$ \\
\hline
\end{tabular}

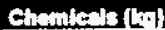

\begin{tabular}{|c|c|c|c|}
\hline 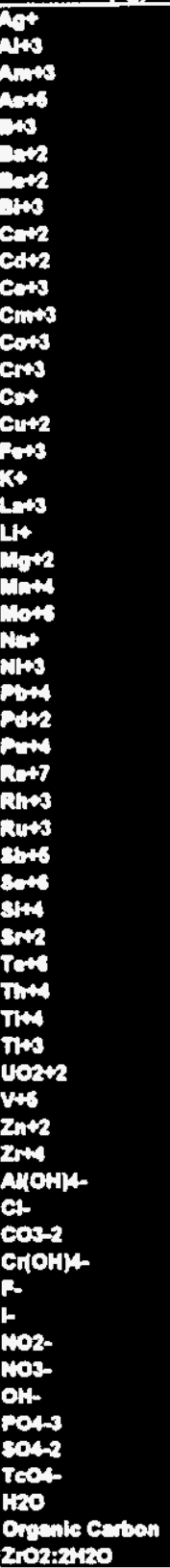 & 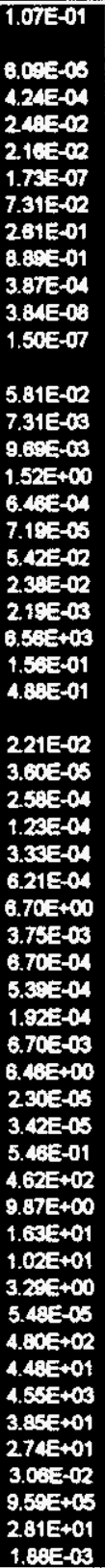 & 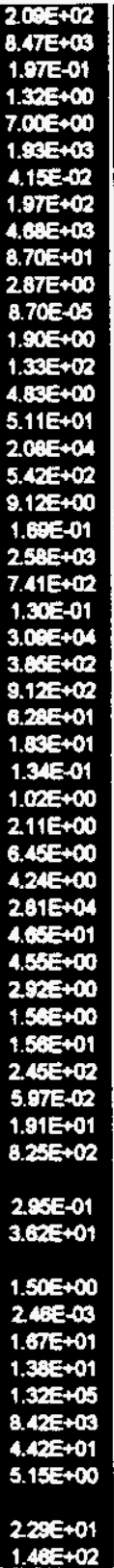 & 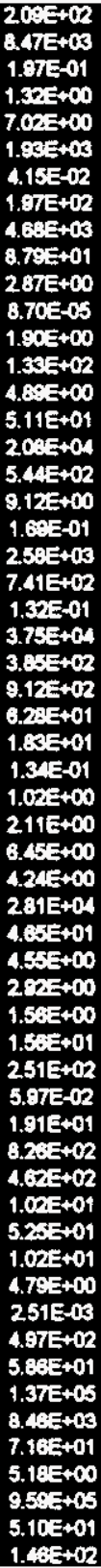 \\
\hline
\end{tabular}

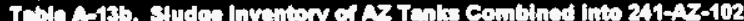

\begin{tabular}{|c|c|c|c|}
\hline קسئ & 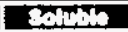 & Incoivble & Tot \\
\hline $\begin{array}{l}\text { Tot hims (kn) } \\
\text { Volcume (ㄴ) }\end{array}$ & $\begin{array}{l}7.94=+05 \\
7.875+05\end{array}$ & $\begin{array}{l}1.805+05 \\
1.24=+06\end{array}$ & $\begin{array}{l}9.92 E+05 \\
9.11 E+05\end{array}$ \\
\hline
\end{tabular}

Volcue (ㄴ)

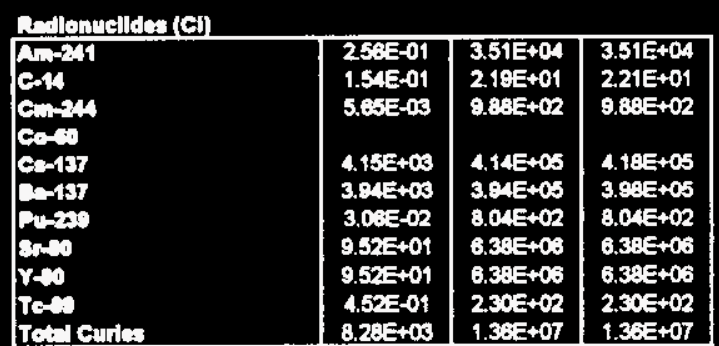

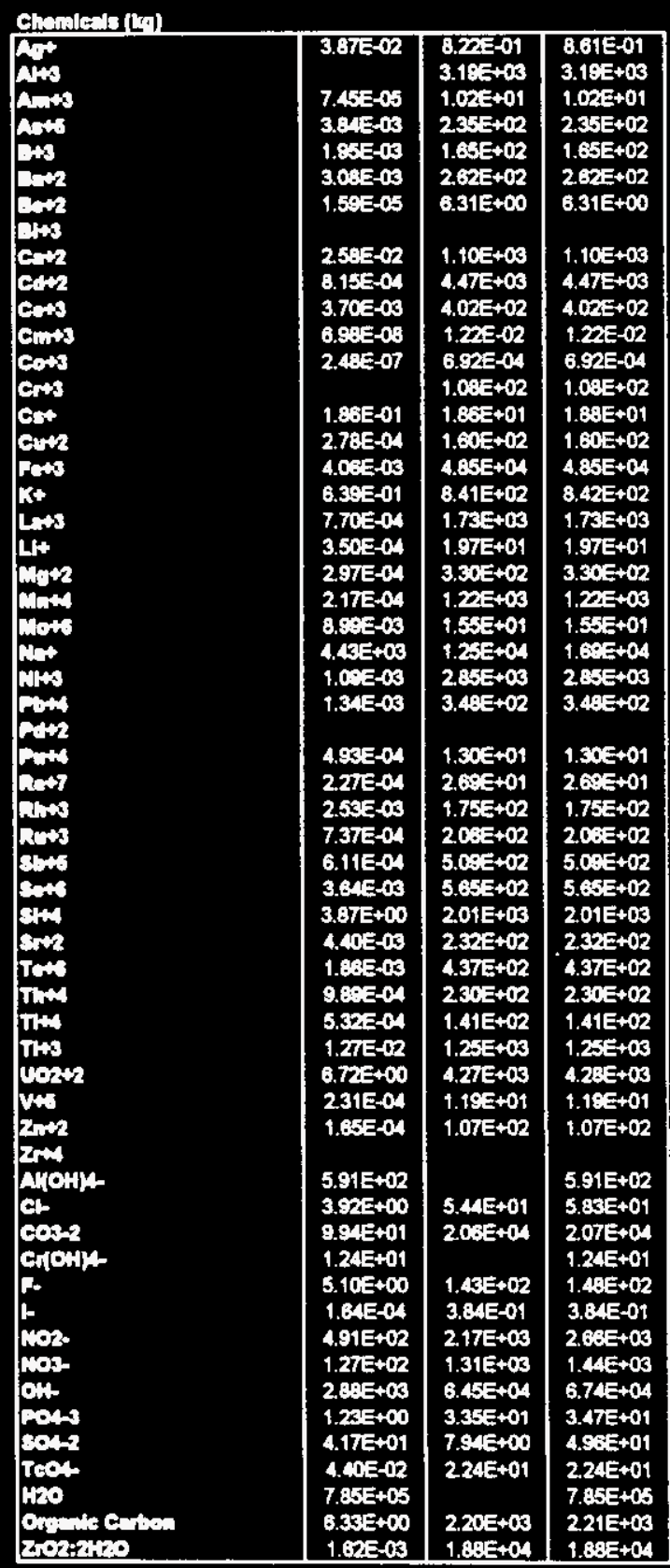


WHC-SD-WM-ES-370

Revision 0

HLW and LLW hwentorise after One Caustic Wach (3 $\mathrm{M}$ OH-) and Two Dilute Caustle Waches

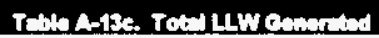

\begin{tabular}{|c|c|c|c|}
\hline Primen & Solunh & Incolubets & 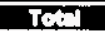 \\
\hline 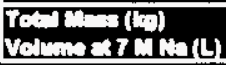 & $\begin{array}{l}211 E+07 \\
4.00=08\end{array}$ & $\begin{array}{l}8.135+03 \\
3.635+03\end{array}$ & $\begin{array}{l}2.11=+07 \\
4.003+08\end{array}$ \\
\hline es] & & & \\
\hline 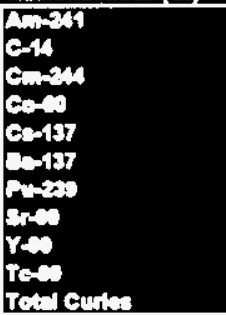 & $\begin{array}{l}1.06 E+02 \\
5.18 E+0 t \\
2.18 E+00 \\
4.85 E+00 \\
1.46 E+08 \\
1.37 E+06 \\
2.02 E+02 \\
3.7 E E+04 \\
3.76 E+04 \\
1.82 E+02 \\
2.00 E+03\end{array}$ & $\begin{array}{l}4.7 E E+02 \\
2.96 E-01 \\
1.32 E+01 \\
7.14 E-01 \\
6.57 E+03 \\
6.25 E+03 \\
2.58 E+01 \\
9.32 E+04 \\
9.32 E+04 \\
3.77 E+00 \\
1.98 E+05\end{array}$ & $\begin{array}{l}5.84 E+02 \\
5.18 E+01 \\
1.54 E+01 \\
5.58 E+00 \\
1.48 E+08 \\
1.38 E+06 \\
2.28 E+02 \\
1.31 E+06 \\
1.31 E+03 \\
1.87 E+02 \\
3.10 E+03\end{array}$ \\
\hline
\end{tabular}

\begin{tabular}{|c|c|c|c|}
\hline 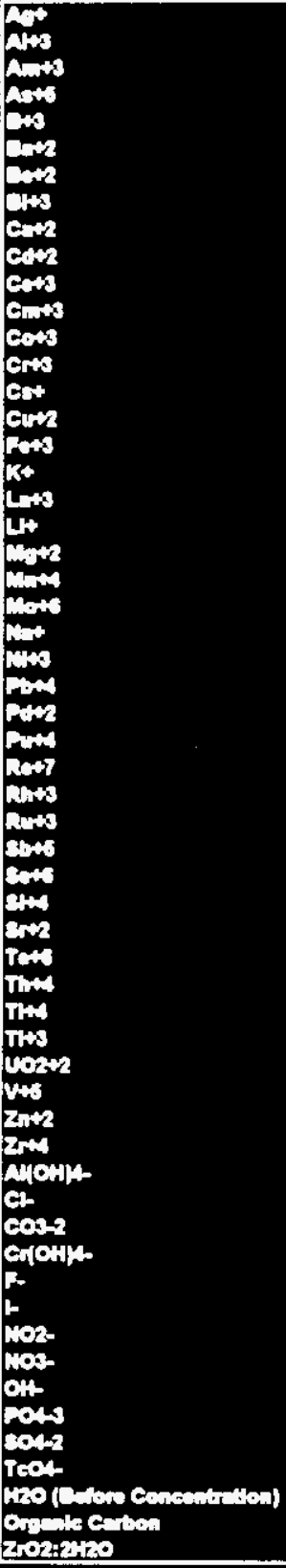 & 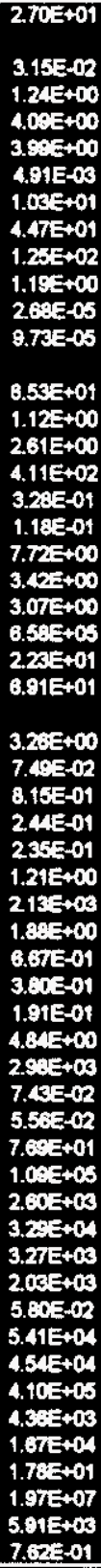 & 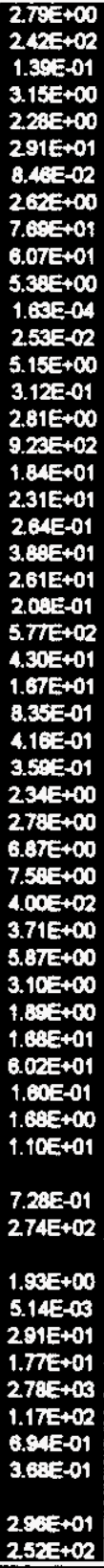 & 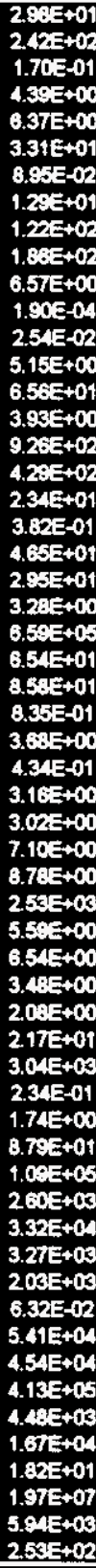 \\
\hline
\end{tabular}


HLW and LWW Inventorise after Ons Caustic Wach (3 M OH-) and Three Dilute Caustic Waches

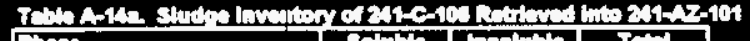

\begin{tabular}{|c|c|c|c|}
\hline Aisens & retom & 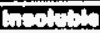 & 70 \\
\hline 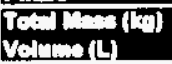 & $\begin{array}{l}9.5+06 \\
0 . x:=06\end{array}$ & $\begin{array}{l}2 \angle 2, E+03 \\
1.51 E+05\end{array}$ & $\begin{array}{l}1.21 E+03 \\
1.11 E+03\end{array}$ \\
\hline ف & & & \\
\hline 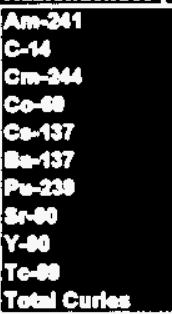 & $\begin{array}{l}5.45 E=02 \\
7.83 E-03 \\
8.00 E-04 \\
8.81 E-03 \\
3.15 E+\infty 2 \\
2.50 E+02 \\
3.58 E-01 \\
1.52 E+01 \\
1.52 E+01 \\
8.18 E-02 \\
6.45 E+02\end{array}$ & $\begin{array}{l}6.73 E+02 \\
2.47 E-01 \\
7.02 E+00 \\
5.36 E+01 \\
7.86 E+04 \\
7.58 E+04 \\
1.13 E+03 \\
6.10 E+05 \\
6.10 E+06 \\
5.27 E+01 \\
1.38 E+00\end{array}$ & 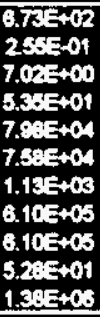 \\
\hline
\end{tabular}

\begin{tabular}{|c|c|c|c|}
\hline 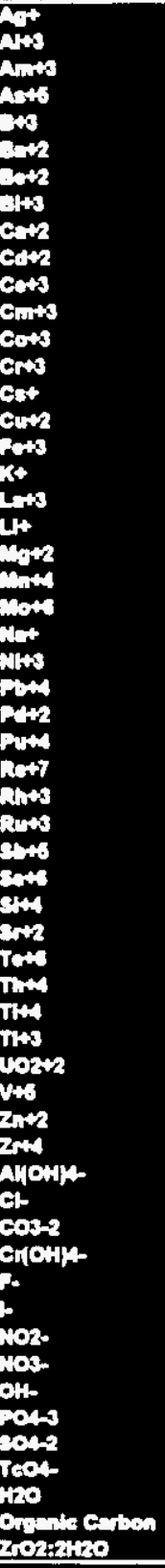 & 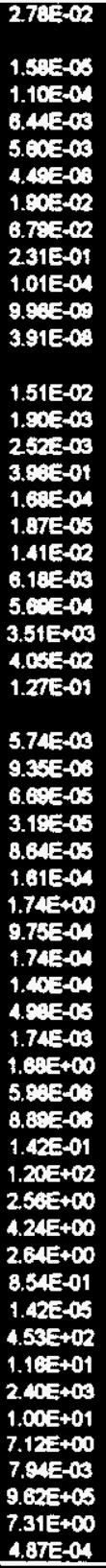 & 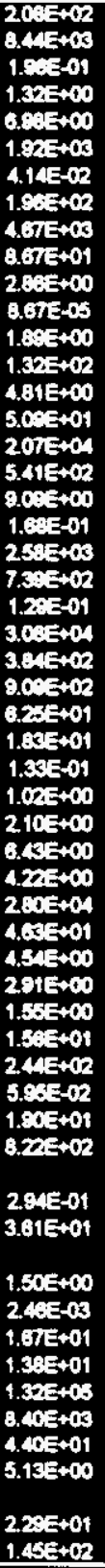 & 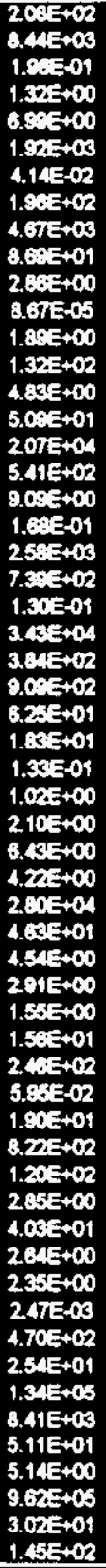 \\
\hline
\end{tabular}

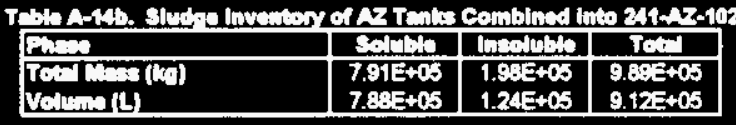

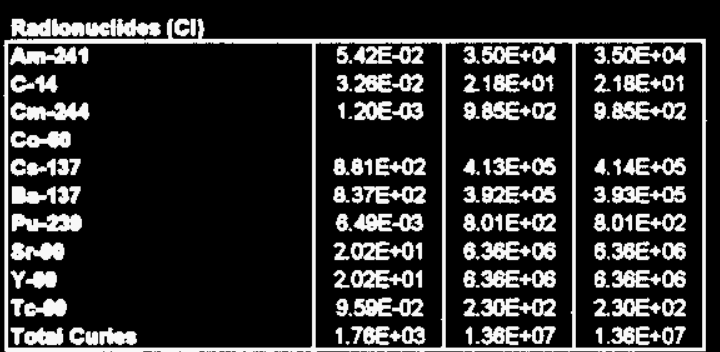

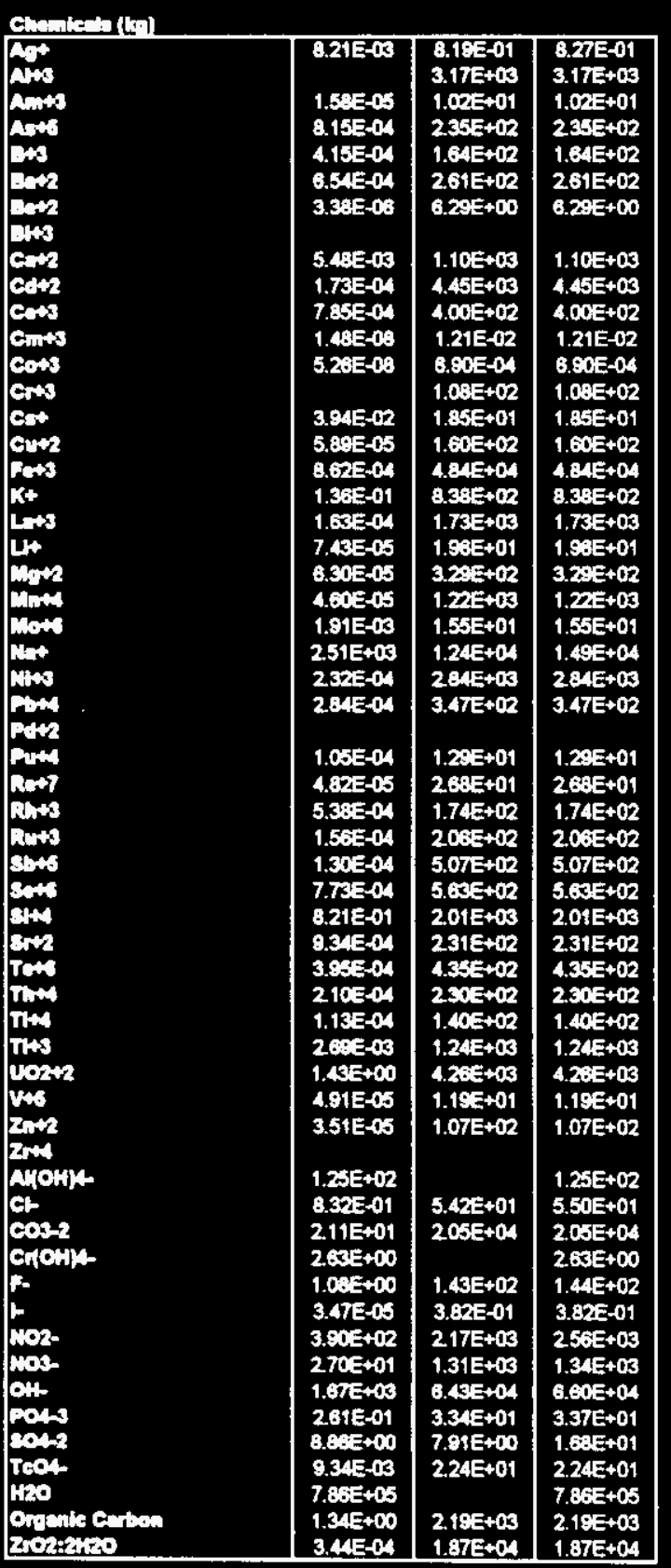




\section{WHC-SD-WM-ES-370 Revision 0}

HLW and LLW Inventories ofter One Caustic Wach (3 $M$ OH-) and Thres Dilute Caustic Washes

\begin{tabular}{|c|c|c|c|}
\hline Pises & Solutis & Insolutiele & Tow \\
\hline 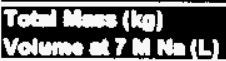 & $\begin{array}{l}2.67 E+07 \\
4.21 E+03\end{array}$ & $\begin{array}{l}7.58 E+03 \\
4.745+03\end{array}$ & $\begin{array}{l}2.67 E+07 \\
427=+06\end{array}$ \\
\hline
\end{tabular}

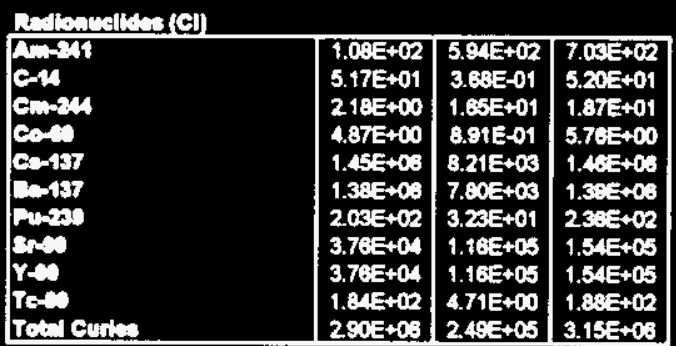

\begin{tabular}{|c|c|c|c|}
\hline 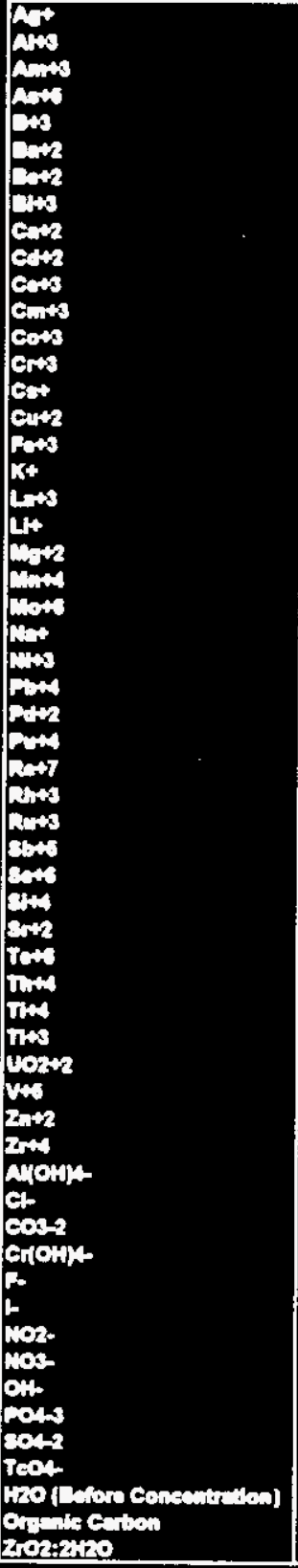 & 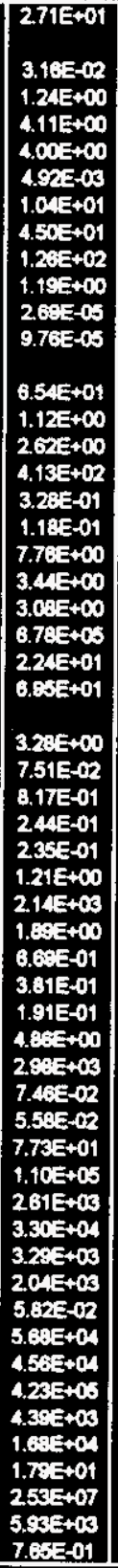 & 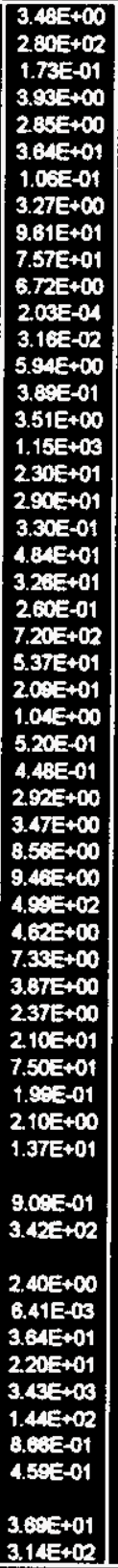 & 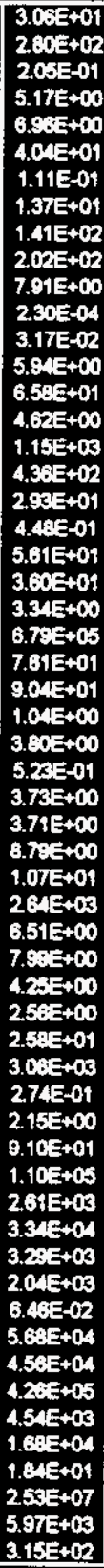 \\
\hline
\end{tabular}


WHC-SD-WM-ES-370

Revision 0

This page intentionally left blank. 
WHC-SD-WM-ES-370

Revision 0

APPENDIX B

PHASE I HIGH-LEVEL WASTE FEED ENVELOPE ASSESSMENT AND RECOMMENDED PHASE I HIGH-LEVEL WASTE FEED SPECIFICATION INPUT

B-1 
WHC-SD-WM-ES-370

Revision 0

This page intentionally left blank. 
WHC-SD-WM-ES-370

Revision 0

\section{APPENDIX B}

\section{PHASE I HIGH-LEVEL WASTE FEED ENVELOPE ASSESSMIENT}

The first four tables of this appendix, S8-1A, S8-1B, S8-2, and S8-3, come directly from the draft RFP (DOE 1995). Following these tables, data tables (Tables B-1 through B-5) from the Feed Envelope Assessment are presented, based upon the draft RFP specifications. Tables B-1 and B-2 are for the base case consolidation scenario, and Tables B-3 through B-5 are for the "no consolidation" case. Each of the columns in Tables B-1 through B-5 represent the concentrations of each waste component in the feed slurry to HLW at $31 \mathrm{~g}$ of waste oxides/L feed. The highlighted areas of Tables B-1 through B-5 indicate component concentrations that are outside the draft RFP limits. Following the Feed Envelope Assessment are the recommended changes to the draft RFP requirements. 


\section{Specification 8: High-Level Waste Envelope Definition}

This specification describes the contents of the high-level waste (HLW) envelope to be transferred to the HLW Contractor for processing. Tables S8-1A and S8-1B describe the estimated composition of major components of pretreated feeds. Table S8-2 describes the design basis maximum feed composition for radionuclide components. Table S8-3 describes the design basis range for selected physical properties of HLW feed delivered to the HLW Contractor. Feed will be delivered to the HLW Contractor by pipeline in batches.

Table S8-1A. Estimated Composition of Pretreated Feed(s).

\begin{tabular}{|c|c|c|c|c|c|c|c|}
\hline \multirow{2}{*}{$\begin{array}{l}\text { Non- } \\
\text { volatile } \\
\text { element }\end{array}$} & \multicolumn{3}{|c|}{$\mathrm{g} / \mathrm{L}$} & \multirow{2}{*}{$\begin{array}{l}\text { Non- } \\
\text { volatile } \\
\text { element }\end{array}$} & \multicolumn{3}{|c|}{$\mathrm{g} / \mathrm{L}$} \\
\hline & Nominal & Minimum & Maximum & & Nominal & Minimum & Maximum \\
\hline $\mathrm{Ag}$ & 0.045 & NE & 0.10 & $\mathrm{Ge}$ & NE & $\mathrm{NE}$ & $3.4 \mathrm{E}-05$ \\
\hline $\mathrm{Al}$ & 1.51 & 1 & 3.3 & $\mathbf{H g}$ & $\mathrm{NE}$ & NE & Trace \\
\hline Am & NE & $\mathrm{NE}$ & 0.02 & Ho & NE & NE & 1.4 E-06 \\
\hline As & 0.021 & NE & 0.05 & I & NE & NE & $1.4 \mathrm{E}-06$ \\
\hline B & 0.019 & $\mathrm{NE}$ & 0.39 & In & $\mathrm{NE}$ & NE & $3.3 \mathrm{E}-04$ \\
\hline $\mathrm{Ba}$ & 0.18 & 0.00 & 1.4 & $\mathbf{K}$ & .181 & $\mathrm{NE}$ & 0.41 \\
\hline $\mathrm{Be}$ & 0.017 & $\mathrm{NE}$ & 0.022 & $\mathrm{La}$ & 0.16 & 0.00 & 0.53 \\
\hline $\mathrm{Bi}$ & NE & 0.00 & 0.86 & $\mathrm{Mg}$ & 0.248 & NE & 0.65 \\
\hline $\mathrm{Ca}$ & 0.50 & 0.00 & 1.8 & $\mathrm{Mn}$ & 0.45 & 0.00 & 2 \\
\hline $\mathrm{Cd}$ & 0.42 & 0.00 & 2.2 & Mo & 0.003 & 0.00 & 1.7 \\
\hline $\mathrm{Ce}$ & 0.04 & 0.00 & 0.25 & $\mathrm{Na}$ & 5.70 & 3 & 6 \\
\hline $\mathrm{Cr}$ & 0.08 & 0.04 & 0.25 & $\mathrm{Nb}$ & $\mathrm{NE}$ & NE & 0.003 \\
\hline Cs & $\mathrm{NE}$ & NE & 0.18 & Nd & 0.11 & 0.00 & 0.53 \\
\hline $\mathrm{Cu}$ & 0.018 & NE & 0.15 & $\mathrm{Ni}$ & 0.29 & 0.05 & 0.61 \\
\hline Dy & 0.002 & NE & $2.7 \mathrm{E}-05$ & Np & $\mathrm{NE}$ & $\mathrm{NE}$ & 0.027 \\
\hline $\mathrm{Er}$ & NE & NE & 8.4 E-07 & $\mathbf{P}$ & 0.05 & 0.01 & 0.19 \\
\hline $\mathrm{Eu}$ & $\mathrm{NE}$ & $\mathrm{NE}$ & 0.005 & $\mathrm{~Pb}$ & 0.109 & NE & 0.34 \\
\hline $\mathrm{F}$ & 0.03 & 0.00 & 0.3 & Pd & $\mathrm{NE}$ & NE & 0.054 \\
\hline $\mathrm{Fe}$ & 6.10 & 3.3 & 8.9 & $\mathrm{Pm}$ & $\mathrm{NE}$ & $\mathrm{NE}$ & 0.027 \\
\hline Gd & NE & $\mathrm{NE}$ & 0.003 & $\operatorname{Pr}$ & $\mathrm{NE}$ & NE & 0.11 \\
\hline
\end{tabular}


WHC-SD-WM-ES-370

Revision 0

Table S8-1A. Estimated Composition of Pretreated Feed(s), continued.

\begin{tabular}{|c|c|c|c|c|c|c|c|}
\hline \multirow{2}{*}{$\begin{array}{l}\text { Non- } \\
\text { volatile } \\
\text { element }\end{array}$} & \multicolumn{3}{|c|}{$g / L$} & \multirow{2}{*}{$\begin{array}{l}\text { Non- } \\
\text { volatile } \\
\text { element }\end{array}$} & \multicolumn{3}{|c|}{$\mathrm{g} / \mathrm{L}$} \\
\hline & Nominal & Minimum & Maximum & & Nominal & Minimum & Maximum \\
\hline Pu & 0.0014 & NE & 0.016 & Tb & $\mathrm{NE}$ & NE & $6.2 \mathrm{E}-05$ \\
\hline $\mathbf{R b}$ & $\mathrm{NE}$ & $\mathrm{NE}$ & 0.048 & Tc & NE & NE & 0.079 \\
\hline $\mathbf{R h}$ & 0.016 & NE & 0.50 & $\mathrm{Te}$ & 0.036 & $\mathrm{NE}$ & 0.062 \\
\hline $\mathbf{R u}$ & 0.017 & NE & 0.17 & $\mathrm{Ti}$ & 0.01 & 0.00 & 0.74 \\
\hline $\mathbf{S}$ & 0.06 & 0.00 & 0.10 & $\mathrm{Tl}$ & NE & NE & 0.083 \\
\hline $\mathrm{Sb}$ & 0.04 & $\mathrm{NE}$ & 0.26 & $\mathrm{Tm}$ & NE & NE & $4.6 \mathrm{E}-11$ \\
\hline Se & 0.049 & NE & 0.12 & $\mathbf{U}$ & 0.38 & 0.00 & 2.1 \\
\hline $\mathrm{Si}$ & 2.43 & 0.26 & 5.1 & V & 0.001 & $\mathrm{NE}$ & 0.009 \\
\hline $\mathrm{Sm}$ & NE & NE & 0.053 & W & NE & NE & 0.074 \\
\hline Sn & NE & $\mathrm{NE}$ & 0.011 & $Y$ & NE & NE & 0.049 \\
\hline $\mathrm{Sr}$ & 0.018 & $\mathrm{NE}$ & 0.16 & $\mathbf{Z n}$ & 0.011 & $\mathrm{NE}$ & 0.13 \\
\hline Ta & $\mathrm{NE}$ & $\mathrm{NE}$ & 0.008 & $\mathrm{Zr}_{\mathbf{r}}$ & 0.98 & 0.02 & 2.8 \\
\hline
\end{tabular}

Table S8-1B. Estimated Composition of Pretreated Feed(s).

\begin{tabular}{|l|c|c|c|}
\hline \multirow{2}{*}{ Volatile components } & \multicolumn{3}{|c|}{$\mathrm{g} / \mathrm{L}$} \\
\cline { 2 - 4 } & Nominal & Minimum & Maximum \\
\hline $\mathrm{Cl}$ & 0.01 & 0 & 0.1 \\
\hline $\mathrm{CO}_{3}$ & 5.0 & 0.74 & 9.3 \\
\hline $\mathrm{NO}_{2}{ }^{-}$ & 1.73 & 0 & 11.2 \\
\hline $\mathrm{NO}_{3}{ }^{-}$ & 0.11 & 0 & $\left(\right.$ total $\left.\mathrm{NO}_{2} / \mathrm{NO}_{3}\right)$ \\
\hline $\mathrm{TOC}^{*}$ & 0.62 & 0 & 3.4 \\
\hline $\mathrm{CN}^{*}$ & $\mathrm{NE}$ & 0 & TBD \\
\hline $\mathrm{NH}_{3}$ & $\mathrm{NE}$ & 0 & TBD \\
\hline
\end{tabular}

Notes:

${ }^{1}$ Concentration values given in this table are based on an overall waste concentration of $31 \mathrm{~g}$ non-volatile oxides/L. Concertitation values given in this table will vary in direct proportion to actual overall concentration of percent non-volatile oxides.

${ }^{2}$ Maximum value for the sum of non-volatile fission products and minor components (i.e., all nonvolatile elements except (Al, Ba, Bi, Ce, Ca, Cd, Fe, La, Nd, Mn, Mo, $\mathrm{Na}, \mathrm{Ni}, \mathrm{Si}, \mathrm{Ti}, \mathrm{U}, \mathrm{Zr}, \mathrm{Cr}, \mathrm{Pd}, \mathrm{Hr}, \mathrm{Hu}$, $P, S, F)$ is 5.0 wt \% on oxide basis.

${ }^{3}$ Maximum concentrations of individual fission products are shown in Table S8-2.

${ }^{4} \mathrm{NE}=$ Not Estimate; TOC = Total Organic Carbon; TBD = To Be Determined. 
Table S8-2. Maximum Radionuclide Composition of Pretreated Feed.

\begin{tabular}{|c|c|c|c|c|c|}
\hline Isotope & $\mathrm{Ci} / \mathrm{L}$ & Isotope & $\mathrm{Ci} / \mathrm{L}$ & Isotope & $\mathrm{Ci} / \mathrm{L}$ \\
\hline${ }^{3} \mathrm{H}$ & 2 E-05 & ${ }^{113} \mathrm{Sn}$ & 1.88 E-06 & ${ }^{147} \mathrm{Pm}$ & $2.96 \mathrm{E}+00$ \\
\hline${ }^{14} \mathrm{C}$ & $1 \mathrm{E}-06$ & ${ }^{115 m} \mathrm{Cd}$ & $6.55 \mathrm{E}-10$ & ${ }^{148 m} \mathrm{Pm}$ & 9.85 E-10 \\
\hline${ }^{55} \mathrm{Fe}$ & $1.05 \mathrm{E}-02$ & ${ }^{119 m} \mathrm{Sn}$ & 4.04 E-04 & ${ }^{151} \mathrm{Sm}$ & $9.3 \mathrm{E}-02$ \\
\hline${ }^{59} \mathrm{Ni}$ & $1.45 \mathrm{E}-05$ & ${ }^{121 m} \mathrm{Sn}$ & 9.0 E-06 & ${ }^{152} \mathrm{Eu}$ & 2.04 E-04 \\
\hline${ }^{60} \mathrm{Co}$ & $3.01 \mathrm{E}-03$ & ${ }^{123} \mathrm{Sn}$ & $2.16 \mathrm{E}-04$ & ${ }^{153} \mathrm{Gd}$ & 8.61 E-07 \\
\hline${ }^{63} \mathrm{Ni}$ & $1.56 \mathrm{E}-03$ & ${ }^{126} \mathrm{Sn}$ & $4.8 \mathrm{E}-05$ & ${ }^{154} \mathrm{Eu}$ & $2.50 \mathrm{E}-02$ \\
\hline${ }^{79} \mathrm{Se}$ & 4.2 E-07 & ${ }^{124} \mathrm{Sb}$ & 2.61 E-09 & ${ }^{155} \mathrm{Eu}$ & 3.06 E-02 \\
\hline${ }^{89} \mathrm{Sr}$ & 4.86 E-06 & ${ }^{126} \mathrm{Sb}$ & 4.83 E-06 & ${ }^{160} \mathrm{~Tb}$ & 8.24 E-09 \\
\hline${ }^{90} \mathrm{Sr}$ & $6.3 \mathrm{E}+00$ & ${ }^{126 \mathrm{~m}} \mathrm{Sb}$ & 3.43 E-05 & ${ }^{234} \mathrm{U}$ & 7.7 E-07 \\
\hline${ }^{90} \mathrm{Y}$ & $6.3 \mathrm{E}+00$ & ${ }^{125} \mathrm{Sb}$ & $1.31 \mathrm{E}-01$ & ${ }^{235} \mathrm{U}$ & $3.2 \mathrm{E}-08$ \\
\hline${ }^{91} Y$ & 5.42 E-05 & ${ }^{125 \mathrm{~m}} \mathrm{Te}$ & 3.20 E-02 & ${ }^{236} \mathrm{U}$ & 8.2 E-08 \\
\hline${ }^{93 m} \mathrm{Nb}$ & 8.7 E-05 & ${ }^{127} \mathrm{Te}$ & 2.20 E-04 & ${ }^{238} \mathrm{U}$ & $5.8 \mathrm{E}-07$ \\
\hline${ }^{93} \mathrm{Zr}$ & $1.4 \mathrm{E}-04$ & ${ }^{1277_{\mathrm{m}} \mathrm{Te}}$ & 2.24 E-04 & ${ }^{237} \mathrm{~Np}$ & $2.3 \mathrm{E}-05$ \\
\hline${ }^{95} \mathrm{Zr}$ & 2.06 E-04 & ${ }^{129} \mathrm{Te}$ & $2.80 \mathrm{E}-11$ & ${ }^{238} \mathrm{Pu}$ & $1.1 \mathrm{E}-04$ \\
\hline${ }^{95} \mathrm{Nb}$ & $4.23 \mathrm{E}-03$ & ${ }^{129 \mathrm{w}} \mathrm{Te}$ & 4.31 E-11 & ${ }^{239} \mathrm{Pu}$ & 9.5 E-04 \\
\hline${ }^{99} \mathrm{Tc}$ & 4.5 E-03 & ${ }^{129} \mathrm{I}$ & 9.0 E-08 & ${ }^{240} \mathrm{Pu}$ & $2.6 \mathrm{E}-04$ \\
\hline${ }^{103} \mathrm{Ru}$ & 2.22 E-08 & ${ }^{134} \mathrm{Cs}$ & 8.98 E-02 & ${ }^{241} \mathrm{Pu}$ & $6.9 \mathrm{E}-03$ \\
\hline${ }^{103 m} \mathrm{Rh}$ & $2.01 \mathrm{E}-08$ & ${ }^{135} \mathrm{Cs}$ & $2.0 \mathrm{E}-04$ & ${ }^{242} \mathrm{Pu}$ & 7.1 E-08 \\
\hline${ }^{106} \mathrm{Ru}$ & $3.72 \mathrm{E}-01$ & ${ }^{137} \mathrm{Cs}$ & $3.80 E+00$ & ${ }^{241} \mathrm{Am}$ & $4.31 \mathrm{E}-02$ \\
\hline${ }^{106} \mathrm{Rh}$ & 3.72 E-01 & ${ }^{137 m} \mathrm{Ba}$ & $3.59 \mathrm{E}+00$ & ${ }^{242} \mathrm{Am}$ & 3.09 E-05 \\
\hline${ }^{107} \mathrm{Pd}$ & $4.0 \mathrm{E}-06$ & ${ }^{141} \mathrm{Ce}$ & 8.43 E-10 & ${ }^{242 \mathrm{~m}} \mathrm{Am}$ & 3.2 E-05 \\
\hline${ }^{110 \mathrm{~m}} \mathrm{Ag}$ & $1.19 \mathrm{E}-04$ & ${ }^{144} \mathrm{Ce}$ & $2.22 \mathrm{E}+00$ & ${ }^{243} \mathrm{Am}$ & 5.02 E-06 \\
\hline${ }^{113 \mathrm{~m}} \mathrm{Cd}$ & $1.09 \mathrm{E}-03$ & ${ }^{144} \mathrm{Pr}$ & 2.22 E+00 & ${ }^{242} \mathrm{Cm}$ & $3.72 \mathrm{E}-05$ \\
\hline${ }^{113 m} \mathrm{Ln}$ & $1.88 \mathrm{E}-06$ & ${ }^{144 m} \mathrm{Pr}$ & 2.67 E-02 & ${ }^{244} \mathrm{Cm}$ & 9.33 E-04 \\
\hline
\end{tabular}

Note: Radionuclide composition values given in this table are based on an overall waste concentration of $31 \mathrm{~g}$ non-volatile oxides/L. Maximum values vary in direct proportion to actual concentration of percent non-volatile oxides. 


\section{$L-\mathbf{g}$}

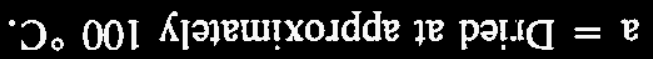

\begin{tabular}{|c|c|c|}
\hline $0 \mathrm{I}<$ & ZI & $\mathrm{H}^{\mathrm{d}}$ \\
\hline$\angle 6^{\circ} 0^{-} 6 L^{\circ} 0$ & $88^{\circ}$ & 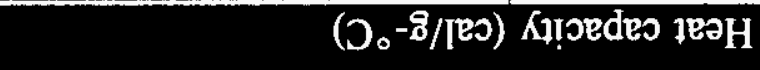 \\
\hline $00 z-0 z$ & OS & 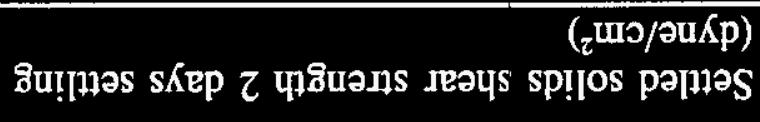 \\
\hline OSI-I & $\$ Z$ & 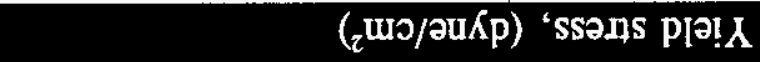 \\
\hline OS-I & \$Z & I-S E8I IE \\
\hline $0 S-\varepsilon$ & $\mathfrak{\Omega}$ & 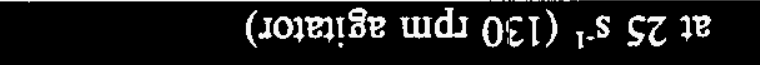 \\
\hline$\downarrow 6-9$ & OS & (I01e) \\
\hline & & 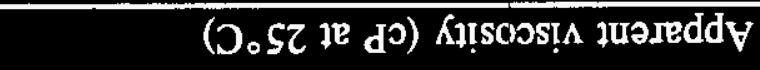 \\
\hline$S Z-L$ & $2 I$ & 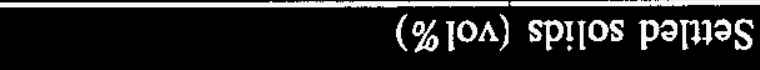 \\
\hline $0 I^{\prime} I-20^{\circ} I$ & $\mathcal{E} 0^{\circ} I$ & 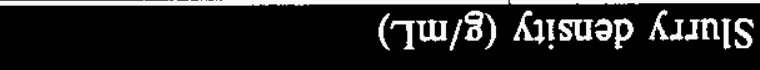 \\
\hline $00 \mathrm{I}-\varsigma 2$ & $I \varepsilon$ & 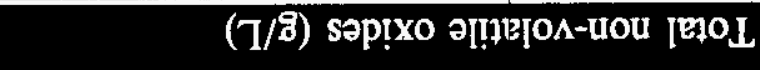 \\
\hline$\varepsilon I-S^{*} Z$ & $\tau^{\dagger} t$ & (\%1M) SPITOS [E]OL \\
\hline 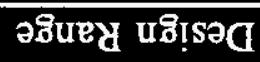 & [EuाuoN & KijadoId \\
\hline
\end{tabular}

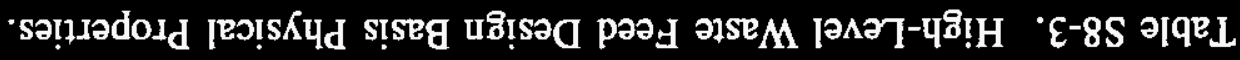


Table B-1a. Draft Request for Proposals Feed Envelope Assessment-Minimum Retrieval, Baseline Consolidation (Bacon 1995).

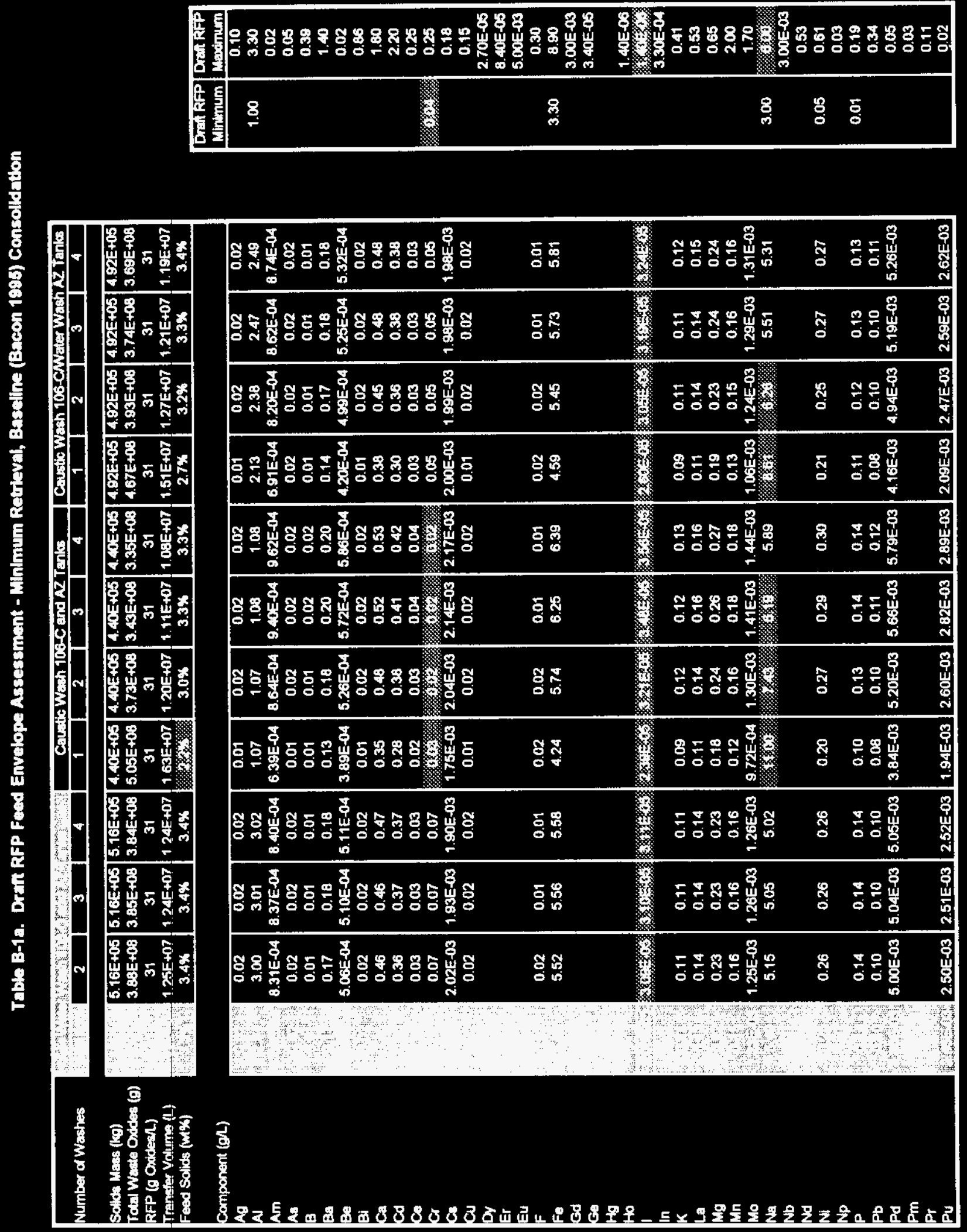


Table B-1b. Draft Request for Proposals Feed Envelope Assessment-Minimum Retrieval, Baseline Consolidation (Bacon 1995). (Continued)

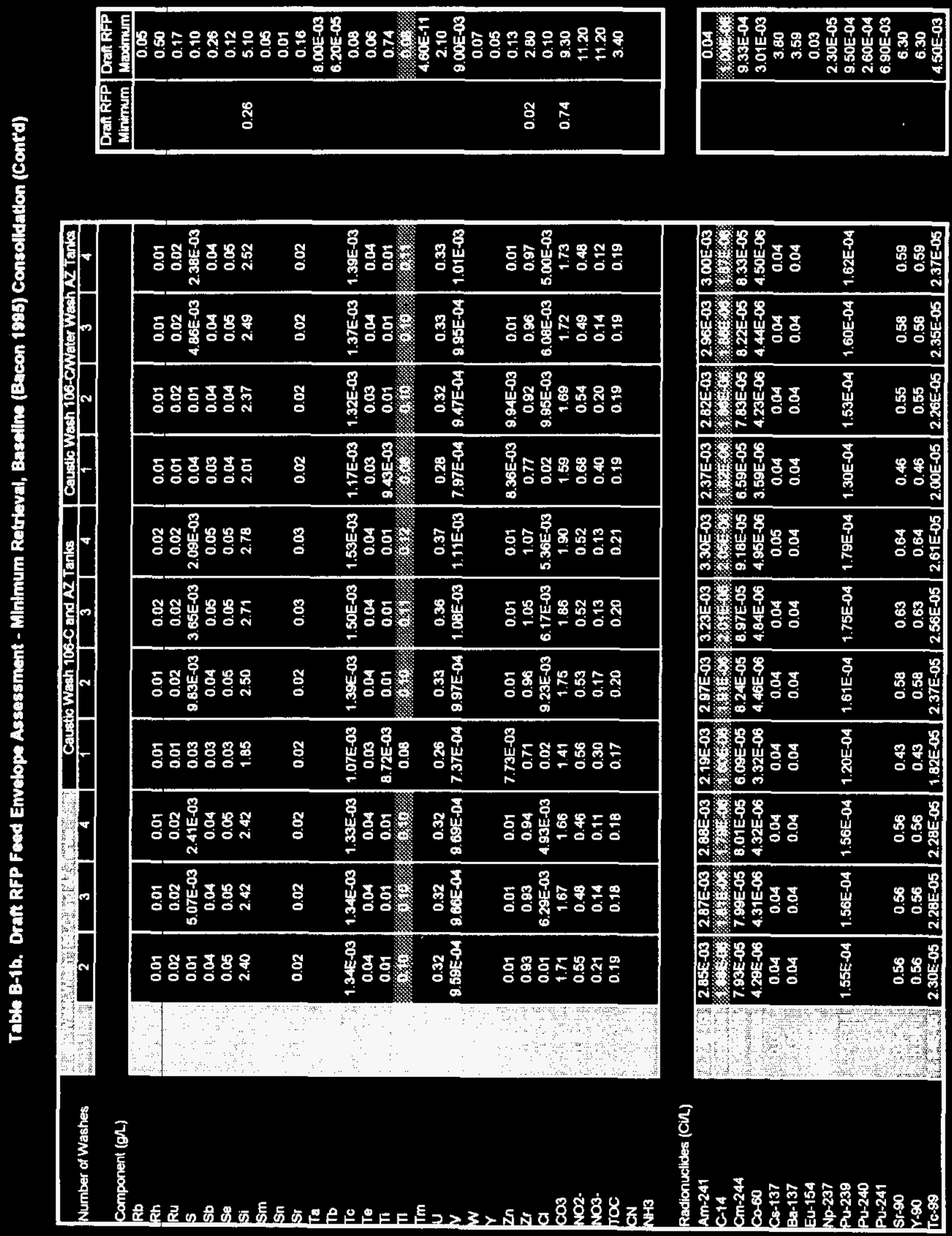


Table B-2a. Dratt RFP Feed Envelope Assessment - Maximum Retrieval, Baseline (Bacen 19as) Consolbdation
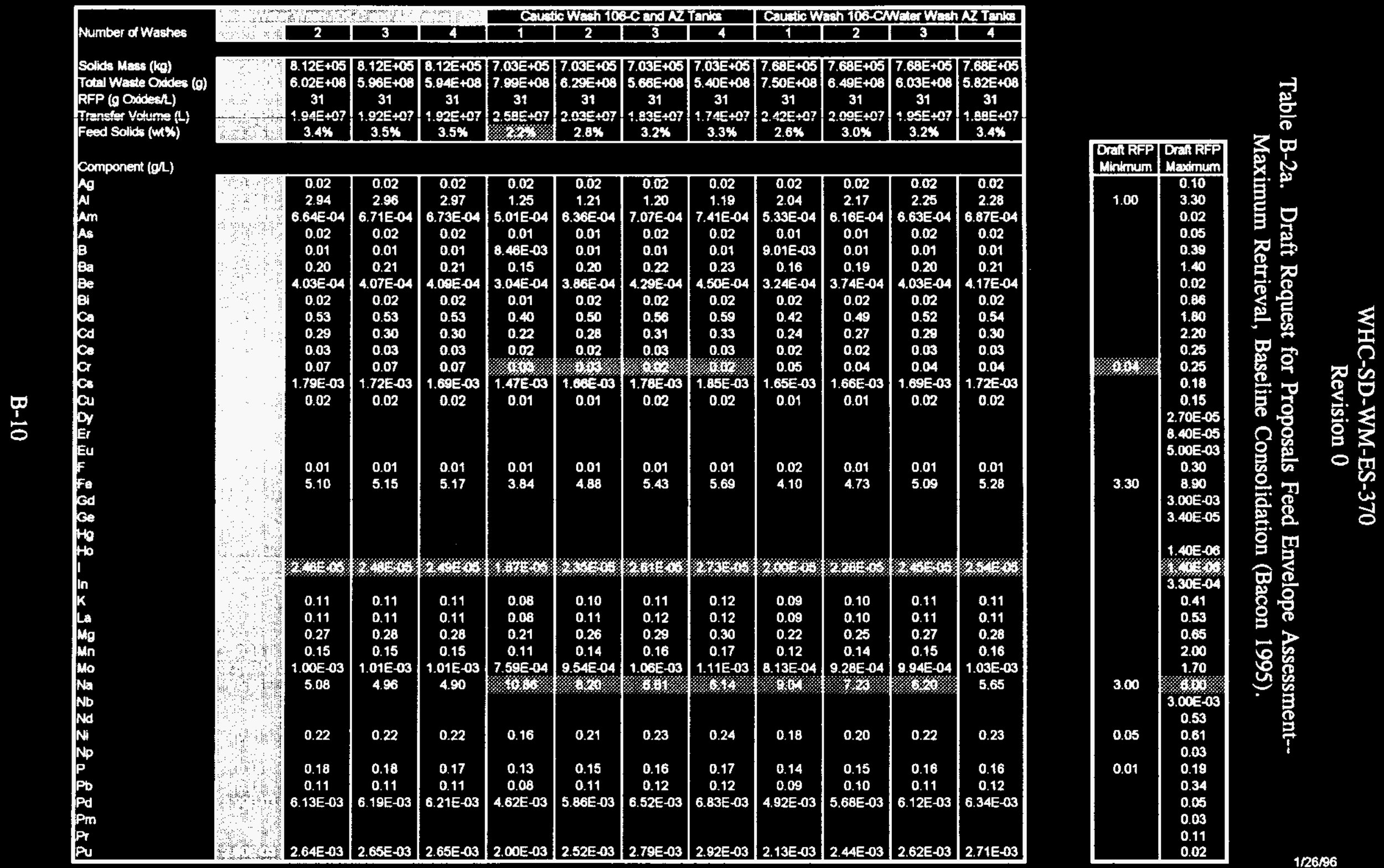
Tabis B-2b. Dratt RFP Feed Envelope Assessmant - Maximum Retrieval, Baseline (Bacon 19es) Consolldation (Contd)

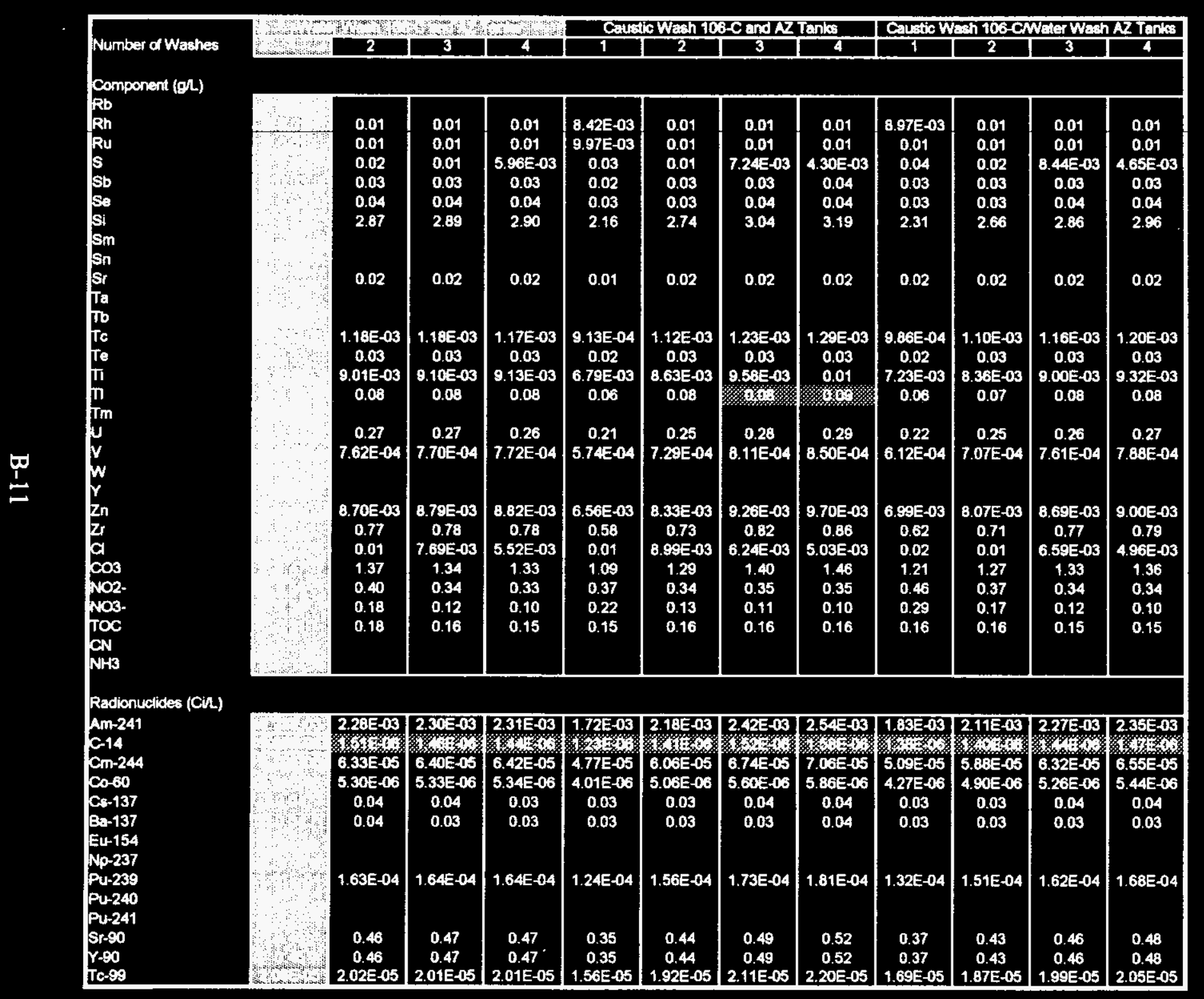


WHC-SD-WM-ES-370

Revision 0

Table B-30. Drait RFP Feed Envelops Assessment - Wash 106-C (75\%) in 102-AY Soparately

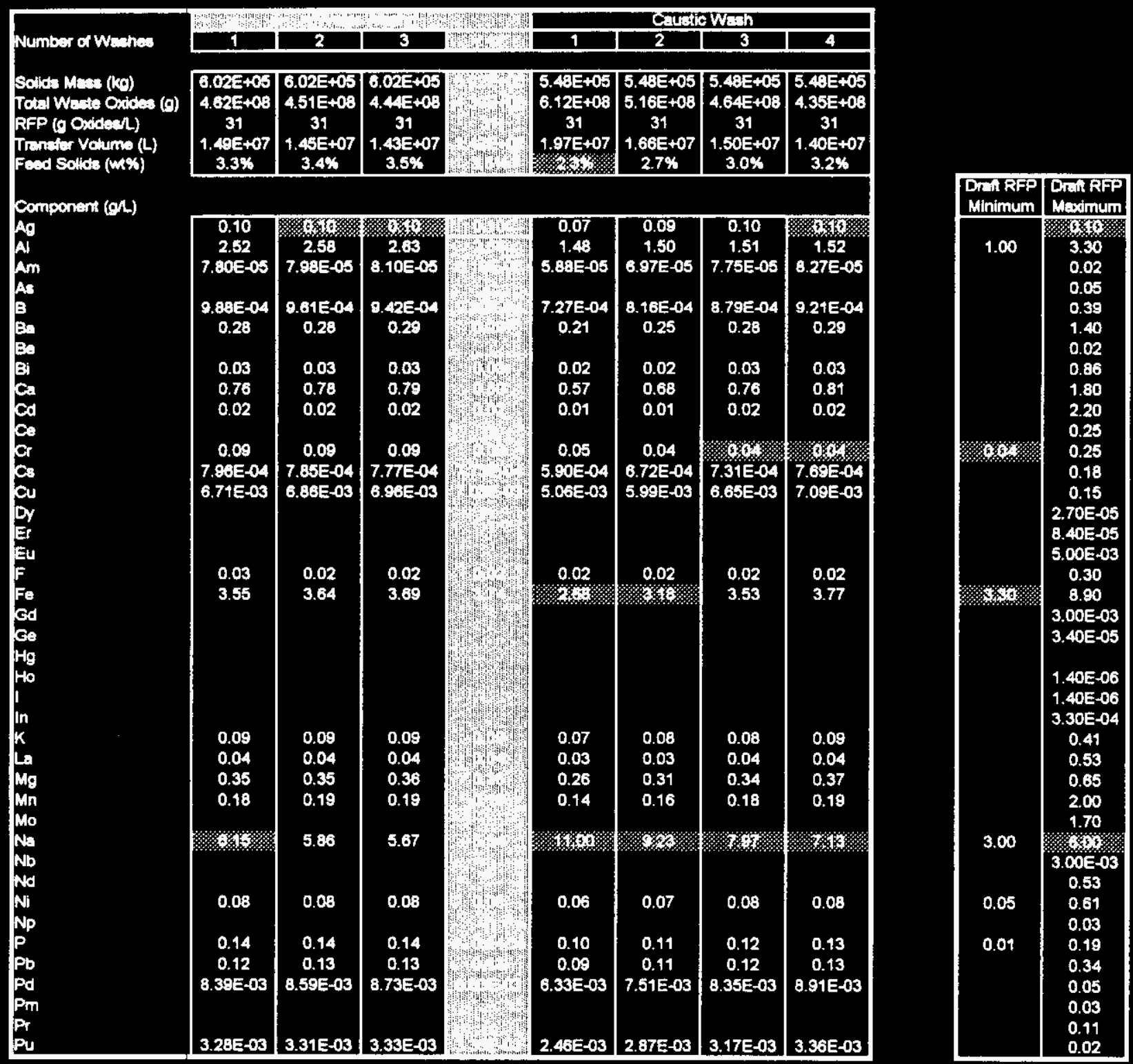


WHC-SD-WM-ES-370

Revision 0

Tabb E-3b. Draft RFP Fced Envalope Asseasment - Wash 106-C (75\%) in 102-AY 8aparately (Contd)

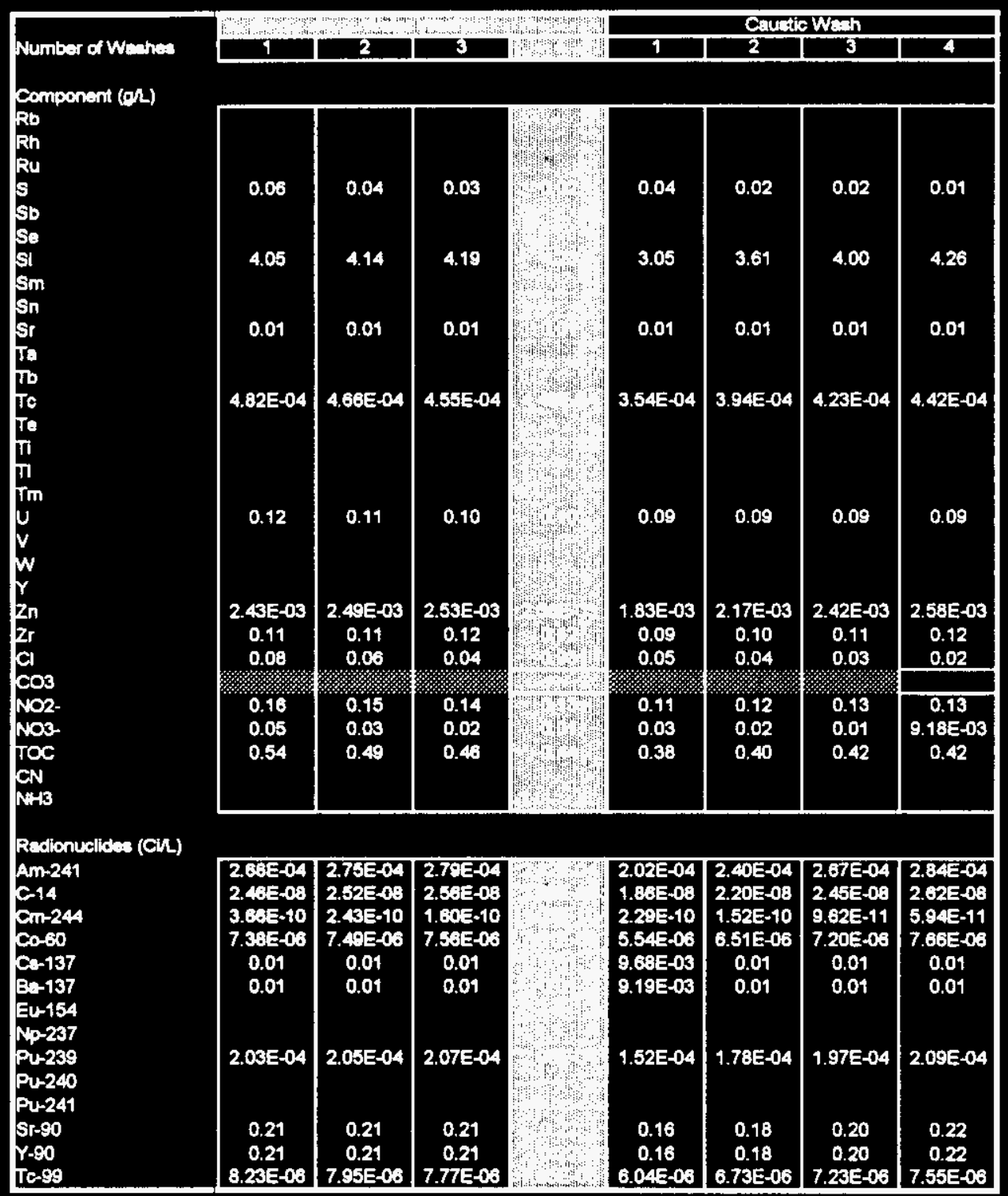

\begin{tabular}{|c|c|}
\hline $\begin{array}{l}\text { Drait RFF } \\
\text { Minimum }\end{array}$ & $\begin{array}{l}\text { Drili } \mathrm{R} F \mathrm{~F} \\
\text { Moximum }\end{array}$ \\
\hline \multirow{22}{*}{0.26} & 0.05 \\
\hline & 0.50 \\
\hline & 0.17 \\
\hline & 0.10 \\
\hline & 0.26 \\
\hline & 0.12 \\
\hline & 5.10 \\
\hline & 0.05 \\
\hline & 0.01 \\
\hline & 0.16 \\
\hline & $8.00 E-03$ \\
\hline & 6.20E-05 \\
\hline & 0.08 \\
\hline & 0.06 \\
\hline & 0.74 \\
\hline & 0.08 \\
\hline & $4.60 E-11$ \\
\hline & 2.10 \\
\hline & 9.00E-03 \\
\hline & 0.07 \\
\hline & 0.05 \\
\hline & 0.13 \\
\hline \multirow[t]{2}{*}{0.02} & 2.80 \\
\hline & 0.10 \\
\hline \multirow[t]{19}{*}{80} & 9.30 \\
\hline & 11.20 \\
\hline & 11.20 \\
\hline & 3.40 \\
\hline & \\
\hline & \\
\hline & 0.04 \\
\hline & 1.00E-06 \\
\hline & $3.01 E-03$ \\
\hline & 3.80 \\
\hline & 3.59 \\
\hline & 0.03 \\
\hline & $2.30=05$ \\
\hline & $9.50 \leq-04$ \\
\hline & $2.60 E 04$ \\
\hline & $6.905=03$ \\
\hline & 6.30 \\
\hline & 6.30 \\
\hline & 4.50E-03 \\
\hline
\end{tabular}


WHC-SD-WM-ES-370

Revision 0

Table B-40. Draft RFP Facd Envolope Assessment - Wash 101-AZ Soparately

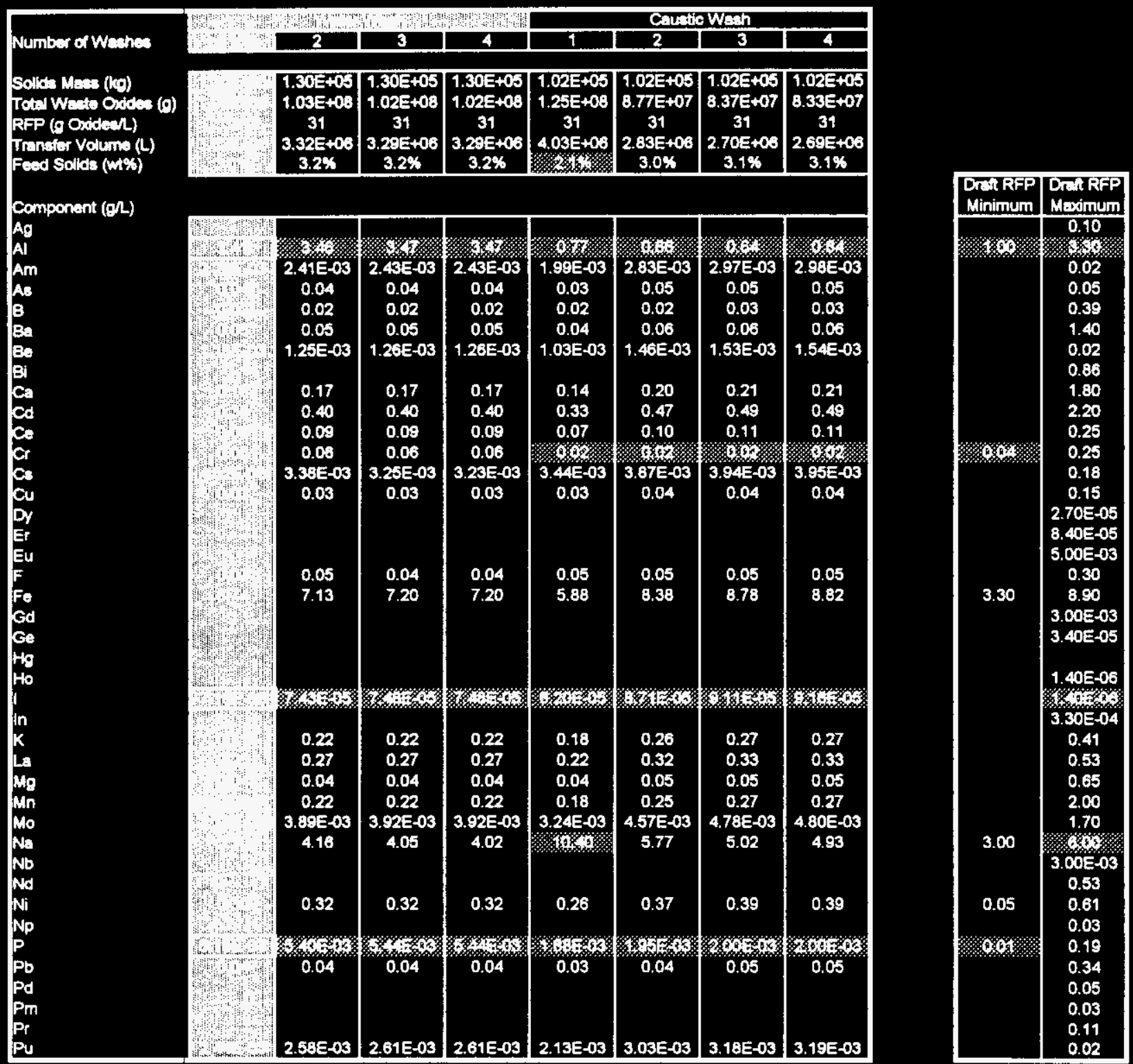


WHC-SD-WM-ES-370

Revision 0

Talbs B-4b. Draft RFP Fesd Envelope Assessment - Wash 101-AZ Soparately (Contd)

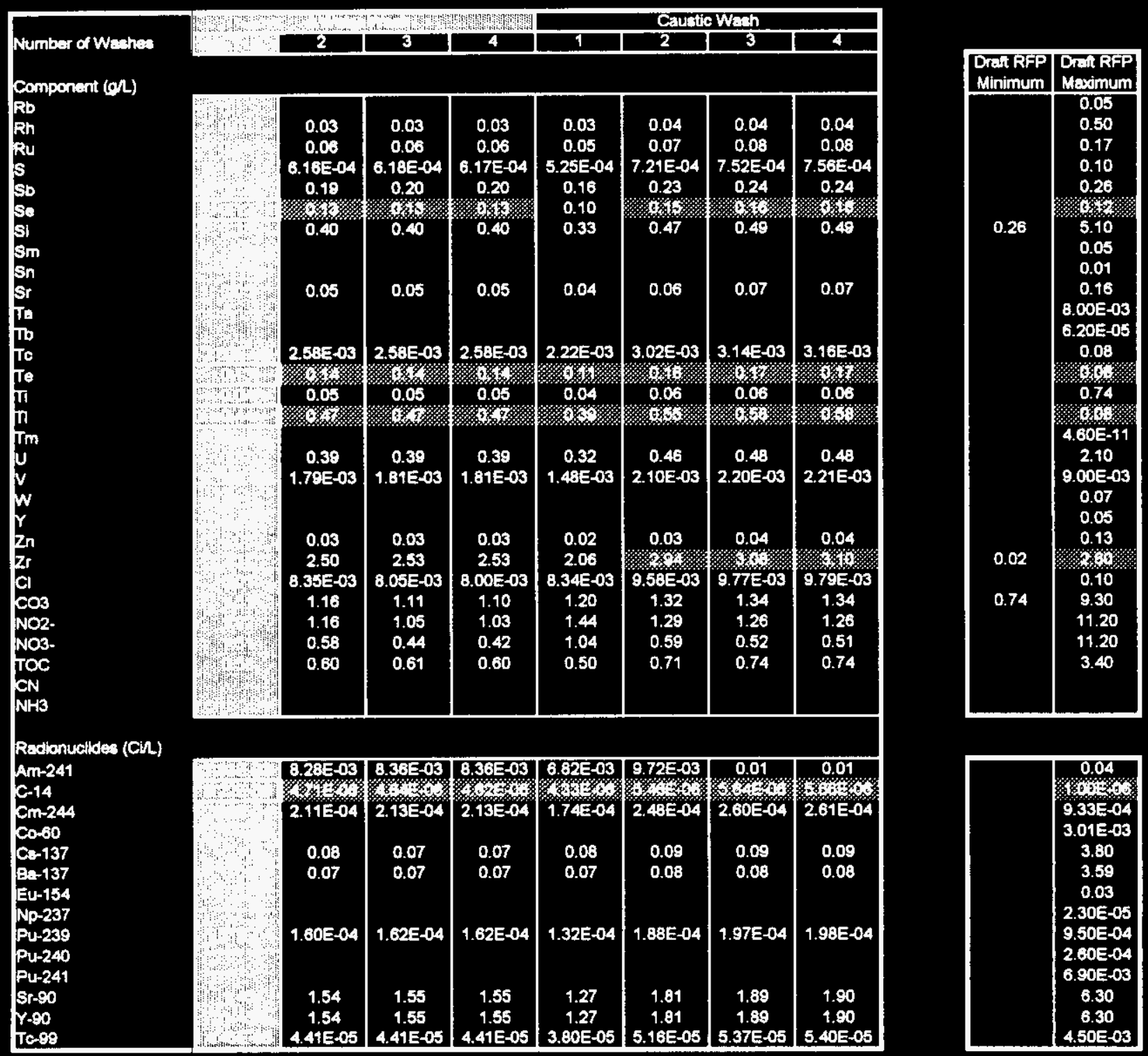




\section{Revision 0}

Tabie B-6a. Drat RFP Foed Envilope Assessment - Wash 102-A2 8oparataly

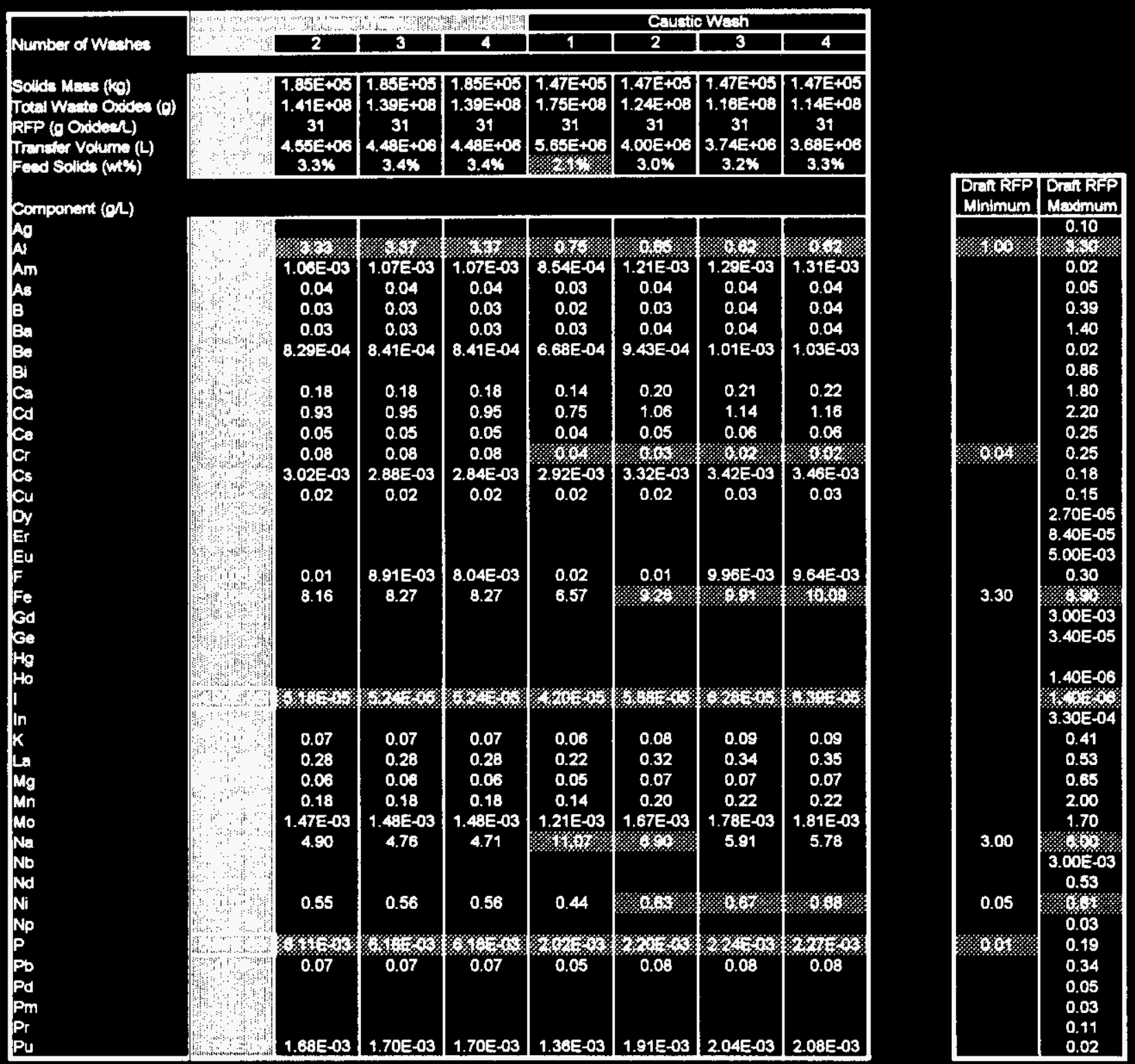


WHC-SD-WM-ES-370

Revision 0

Talow B-6b. Drait RFP Fead Envelope Assessment - Wash 102-Az Seperately (Conte)

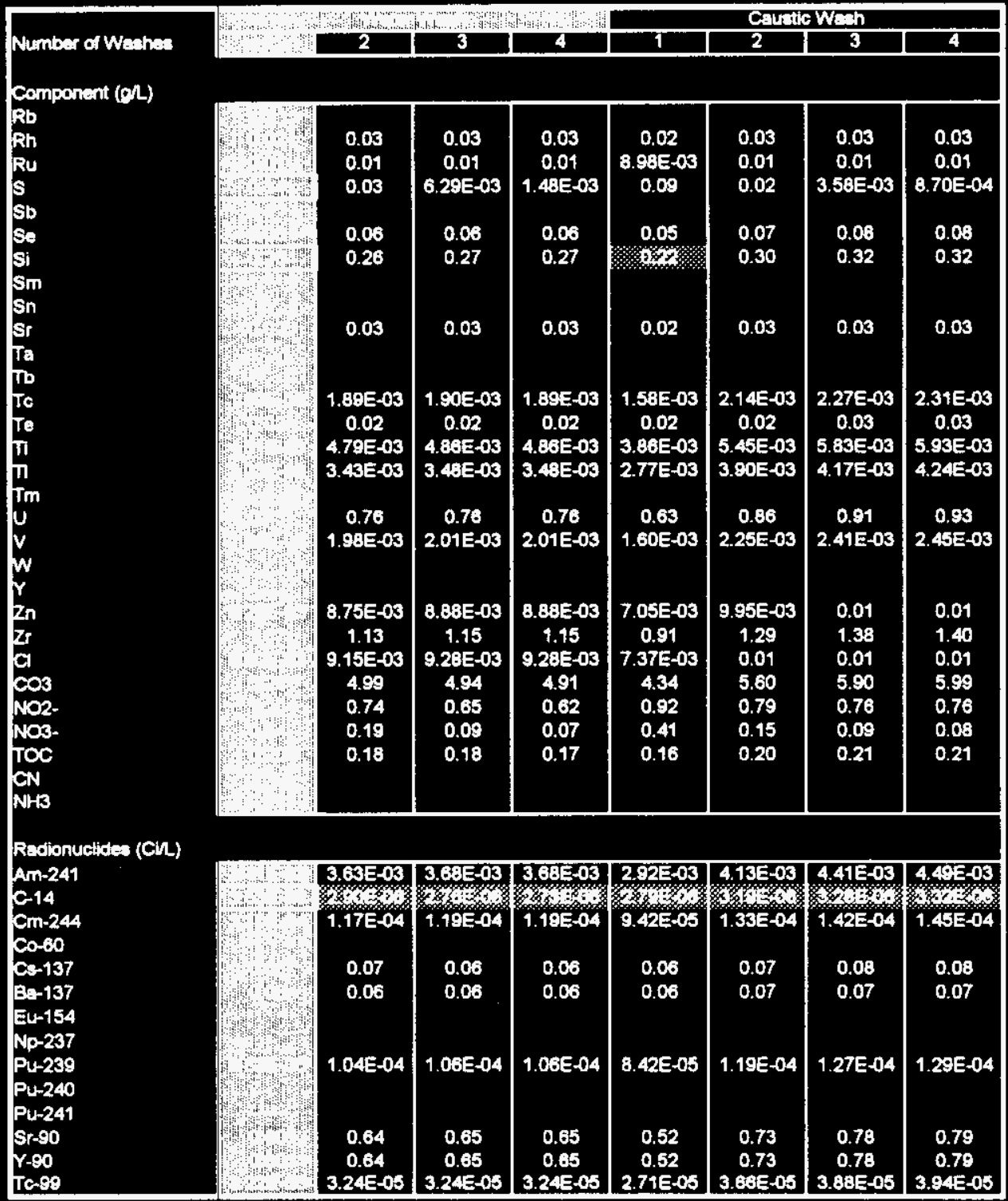

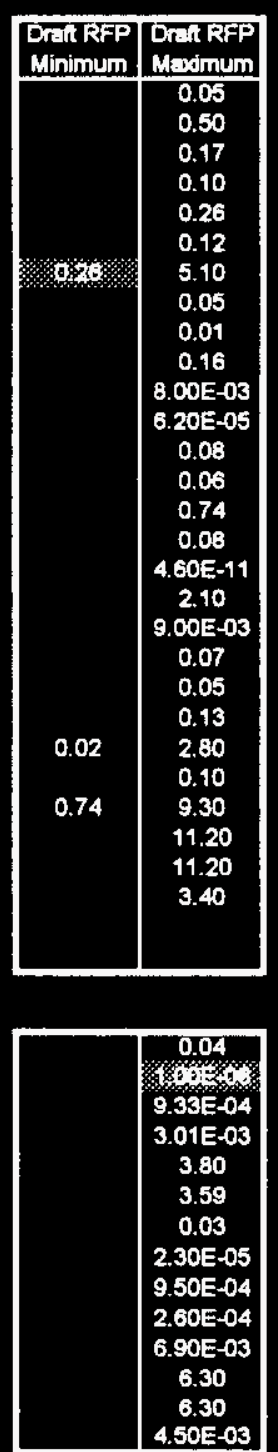




\section{WHC-SD-WM-ES-370 \\ Revision 0}

Table B-6a. Draft Request for Proposals Feed Envelope Assessment--Minimum Retrieval, Baseline (Bacon 1995) Consolidation--Mobilize 102-AY Solids.

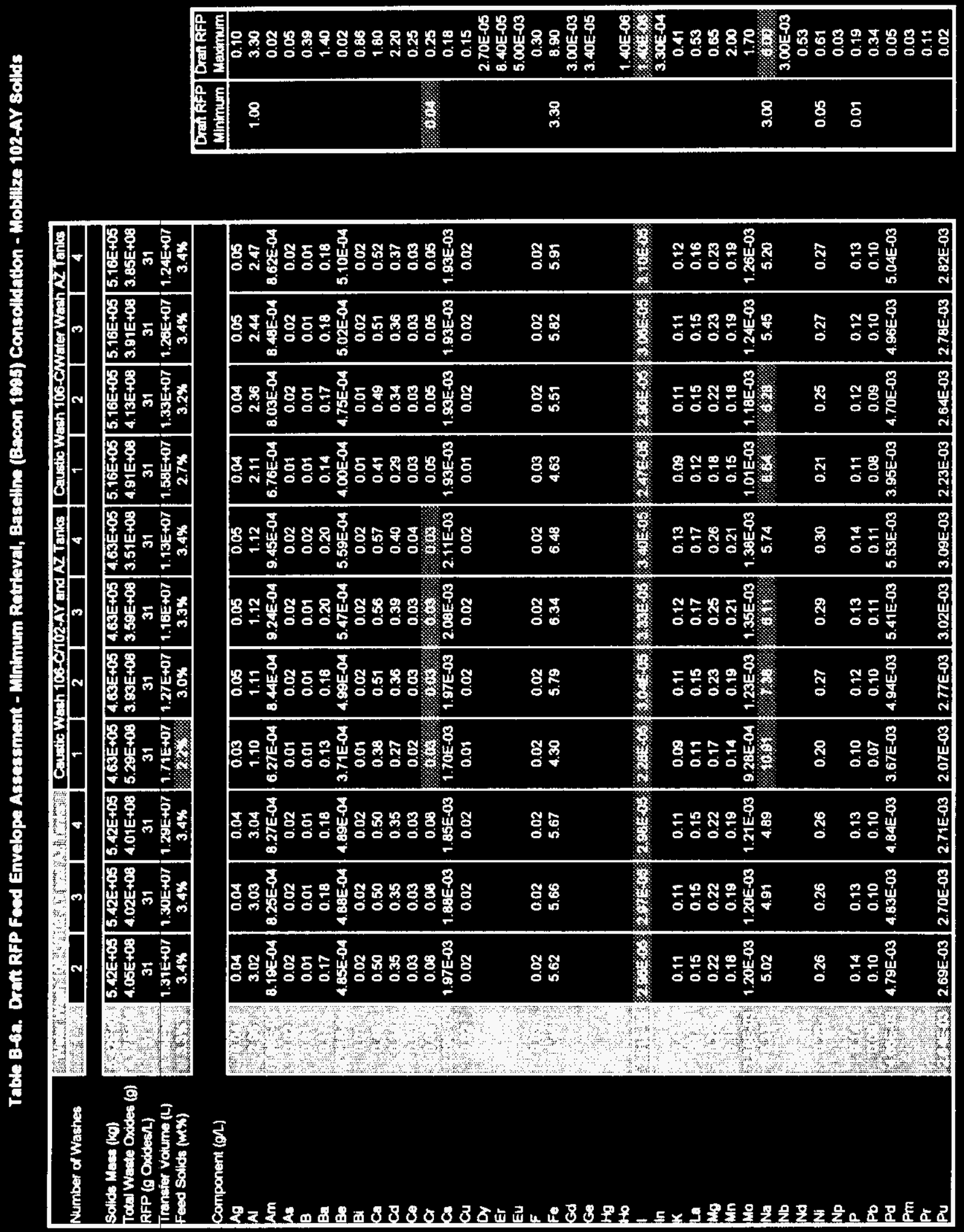




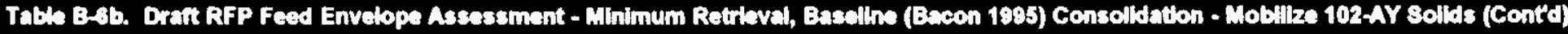

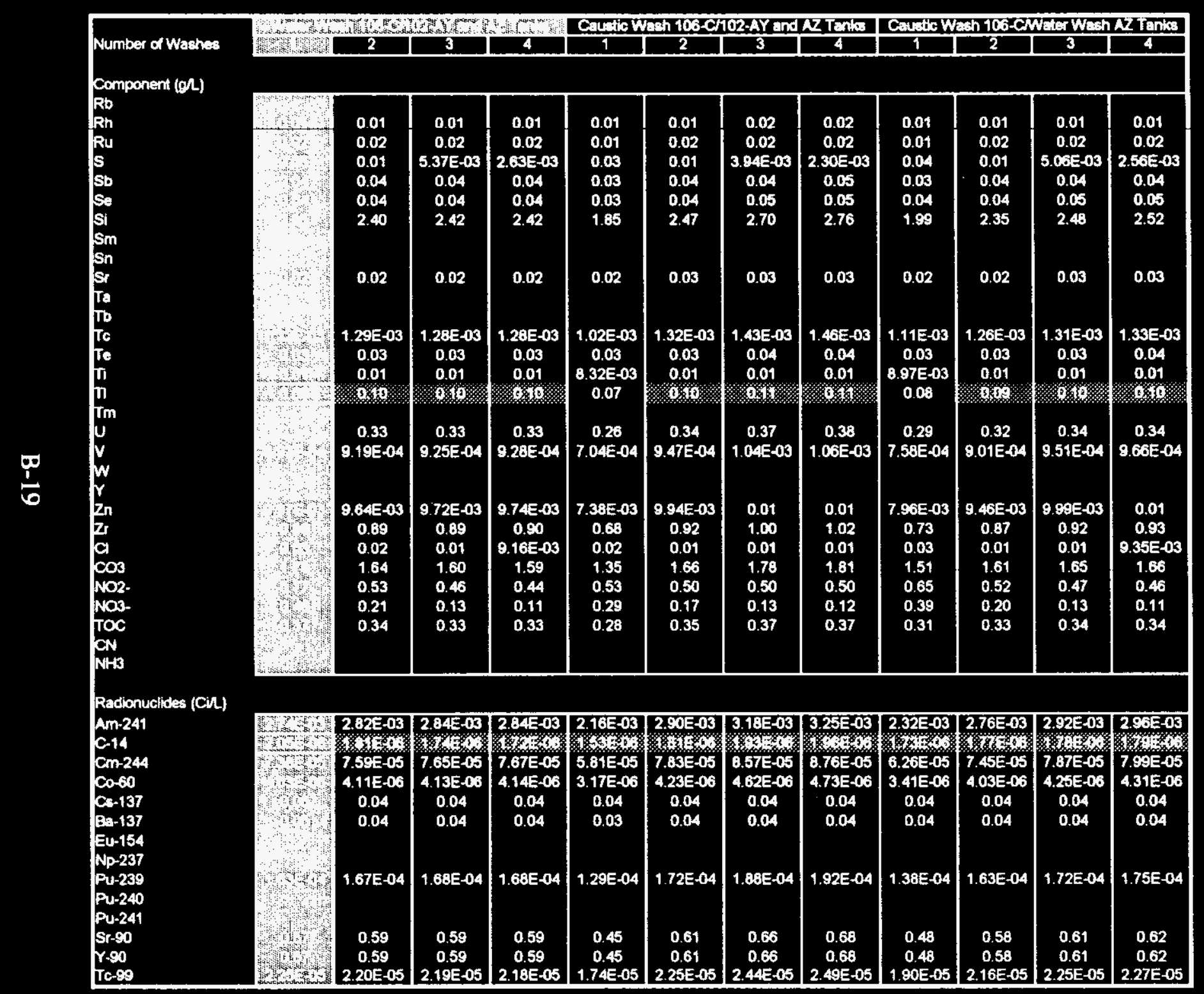


WHC-SD-WM-ES-370

Revision 0

\title{
RECOMMIENDED PHASE I HIGH-LEVEL WASTE FEED SPECINICATION INPUT
}

This section provides recommended input to the Phase I feed specification for highlevel waste (HLW) immobilization as follows:

Phase I HLW immobilization plant design basis feed chemical composition range, design basis feed radionuclide limits, design basis feed physical property limits.

Nominal or current "best estimate" for selected components for overall average Phase I feed composition based on currently designated Phase I feed source tanks (on a post pretreatment basis).

Operating basis feed composition range limits for selected components. The operating basis range is narrower than the design basis range. This range is to be used as the basis for operational planning including estimates of glass production quantity, operating duration, and related cost estimates. It is expected that additional components will be added to the operating basis range, and that the range will be narrowed over time as better data become available and pretreatment, retrieval, and blending scenarios are firmed up.

A draft feed specification was issued in November 1995 as part of the draft RFP. Recommendations herein include a number of changes to the November 1995 draft. Key changes and a summary of the basis or rational for those changes are discussed below. Complete documentation of the basis and rational for feed specification input recommended herein is being prepared and will be issued later in fiscal year 1996.

\section{CHISMICAL COMPOSITION LIMITS}

This section summarizes key changes to chemical composition limits in the draft RFP. Minor adjustments and corrections are not specifically discussed herein, however, the basis for all recommended values will be documented and issued later in Fiscal Year 1996.

\begin{abstract}
Aluminum
Additional evaluation of potential benefits of reducing aluminum by caustic digestion indicates there is likely little benefit from this process. A decision was therefore made to base nominal composition estimates on water washing only (no caustic digestion) versus an assumption of caustic digestion used in for the draft RFP. A more detailed evaluation of available data on aluminum also resulted in an increase in the nominal tank inventory for aluminum in the HLW solids. The result of these two changes is a substantial increase in the nominal aluminum concentration. Based on review of uncertainty in aluminum estimates, the maximum design basis aluminum level was also increased significantly (to $32 \mathrm{wt} \%$ on an
\end{abstract}


oxide basis or $5.3 \mathrm{~g} \mathrm{Al} / \mathrm{L})$. An operating basis maximum of $26 \mathrm{wt} \%$ oxide $(4.3 \mathrm{~g} \mathrm{Al} / \mathrm{L})$ is also recommended. The lower operating basis value avoids an unreasonably high estimate for glass production and operating time that would result if the higher design basis value is used.

\section{Reduction of HWVP Glass Based Feed Limits}

Design basis feed limits previously established for the Hanford Waste Vitrification Plant (HWVP) were used as a starting point in developing feed limits in the draft RFP. A number of HWVP feed limits were originally established based on estimated glass composition limits and a target $25 \mathrm{wt} \%$ waste loading in glass. Higher waste loading is currently being targeted, and it is known that a number of the HWVP glass-based feed limits are excessively high compared to any actual feeds expected to be processed by the HLW plant. A group of feed components was therefore reduced from the HWVP glass-based limits as follows: $\mathrm{CaO}, \mathrm{CdO}, \mathrm{MnO} 2, \mathrm{NiO}, \mathrm{TiO} 2, \mathrm{U} 3 \mathrm{O} 8, \mathrm{ZrO} 2$, and $\mathrm{F}$ all reduced to 50 percent of the HWVP feed limit. Other components and percentage reduction from HWVP basis are: $\mathrm{BaO}$ ( 75 percent), $\mathrm{MoO} 3$ ( 87.5 percent), noble metals (30 percent), Sulfur (25 percent reduction in operating limit only) and $\mathrm{Cr} 203$ (50 percent reduction in operating limit only). For all components that were reduced compared to the HWVP design limits, core sample analyses, and other sources of information were consulted to assure that expected feeds are well within the reduced limits.

Noble Metals, Tellurium, and Silver

The noble metals $(\mathrm{Ru}, \mathrm{Rh}$, and $\mathrm{P})$ were reduced by 30 percent from draft $\mathrm{RFP}$ values (which were equal to HWVP design valued). This reduction was based on a review of core sample data and estimates of what is expected based on fission yield. Estimated concentrations for the maximum waste (from 101-AZ with no credit for blending) are about 30 percent lower than the revised maximum values. Some additional reduction in the design basis may be corsidered in the future if a decision is made to take credit for blending the 101-AZ waste with lower concentration waste or to reduce the contingency margin between the best estimate values and the design limits. Potential further reductions would likely be in the 20 to 40 percent range.

The tellurium ( $\mathrm{Te}$ ) limit was reduced by 35 percent but remains about 40 percent above the HWVP design basis value. The design basis Te value is somewhat of an anomaly in that it does not bound all data in existing data bases (e.g., core sample and tank characterization report data). The problem is that some of the existing databases include data that are either below the detection limit or approximately at the detection limit and therefore has a high uncertainty. To develop a more realistic value, data on fission yields were used to estimate the Te quantity expected in the AZ tanks and ratio of Te to Ru. An additional contingency factor of about 25 percent was added to the Te estimate above that applied to the other noble metals in defining the recommended Te feed limit, so there is good confidence 
that actual feed will not exceed the proposed limit. There also may be some room to reduce the Te limit further if needed in the future if better feed samples and analytical data become available.

Review of data on silver content of Phase I feeds revealed significant differences between data sources. Silver levels were also surprisingly high. The recommended design basis feed limit is an increase by $2 / 3$ from the draft RFP value. The recommended value is on the high end of the uncertainty range and may be at a level that results in impacts to the vitrification process. This component should be given a high priority in future characterization work. The recommended feed specification limit bounds all core sample analyses except for 102-AY. It will be necessary to blend feed from 102-AY with lower silver feeds to stay within the feed specification.

\section{Thallium}

In general, the design basis ranges have been found to bound all other data sources that have been identified. One exception is thallium (Tl). High $\mathrm{Tl}$ values in the tank characterization reports and some TWRS databases results from high "less than detection limit" values being used as actual analyses. There is no known source of thallium near this level and the estimated concentrations in the sludge are thought to be high.

\section{Mercury}

Analyses of a waste sample from 106-C for mercury were performed in 1988 (McCown 1988). Mercury was detected using both the EP Toxicity test, and atomic absorption analysis of acid digested sample. Based on these tests, it appears essentially certain that mercury is present in the 106-C waste. However, actual concentrations measures varied significantly between different analyses. The recommended maximum design basis concentration bounds all identified analyses. Additional analysis is needed to refine the expected mercury content. The actual value may be 50 percent tp $90+$ percent lower than the currently recommended design maximum.

\section{Miscellaneous Changes}

An evaluation of ability to deliver feed within the design range in the Draft RFP was performed by personnel from TWRS Process Engineering (who were independent of WHC personnel that initially provided input to the draft RFP feed specification). A few discrepancies in minor and trace components were identified (P, I and carbon 14). Feed component limits for several items were adjusted based on reconciliation of these independent calculations. 
Four additional components were added to the design basis (Co, $\mathrm{Li}, \mathrm{Re}$, and $\mathrm{Th}$ ). Several trace components were also deleted and replaced with a blanket statement that components below $.001 \mathrm{~g} / \mathrm{L}$ are not listed. This eliminates the need to continue to track these trace components, and covers for trace decay products and impurities that were not previously included in the data base. A number of other corrections and adjustments were made based on checking of the draft RFP values and available composition data.

\section{RADIONUCLIDE LIMITS}

Two primary sources were used to develop radionuclide limits in the draft RFP:

1. The HWVP design basis Reference Feed Maximum Radionuclide Composition, HWV-SD-HWV-DP-001, Rev. 6, Table 13-6. Note that this table requires lower isotope limits for general design purposes than the HWVP shielding source term in Table 12-1 of HWV-SD-HWV-DP-001, Rev. 6.

2. A recent recommendation developed by WHC based on Origen 2 calculations (via the RADNUC 95 code) for pretreated waste from tank 101-AZ with upward adjustment factors for conservatism, processing scenarios that could increase concentrations, core sample results, and consideration of other potential feed sources.

For most isotopes, the higher of the two data sources was used as the draft RFP value. There were a few exceptions where the RADNUC 95 estimates were determined to have excessive conservatism, and a lower value was therefore used (but in all cases greater than or equal to the HWVP limit).

With one exception $\left({ }^{14} \mathrm{C}\right)$, all recommended changes to the revised Table S8-2 are reductions from values in the draft RFP. Most changes were made by starting with the HWVP values, and allowing 10.5 years additional decay time. The decayed HWVP value was then compared to the RADNUC 95 estimates and core sample data (when available). With a few exceptions discussed below, a recommended design basis value was then selected that bounded all three values. Based on this method, a number of isotopes that were relatively high in the HWVP design basis were reduced to levels expected to be of minor or negligible importance. Note that the 10.5 years of additional decay applied to the HWVP values, is conservative, i.e., actual decay time between reactor discharge and waste processing in the HLW plant will be more than 10.5 years longer than assumed when the HWVP design basis feed composition was developed. 
WHC-SD-WM-ES-370

Revision 0

\section{Cesium-137}

Recommended ${ }^{137} \mathrm{Cs}$ limit of $3 \mathrm{Ci} / \mathrm{L}$ at $31 \mathrm{~g}$ total oxide per liter is based on the HWVP Table 13-6 maximum reduced by an additional 10.5 years decay. The level will allow processing of feeds with $\mathrm{Cs}$ from ion exchange blended back in, however. A large spike of accumulated Cs in a small quantity of HLW sludge could not be accommodated. The HWVP shielding basis and the WHC recommendation were based on a "spike" scenario and were therefore much higher than the recommended value (approximately $10 \mathrm{X}$ ).

\section{Strontium-90}

The recommended design basis value of $3.1 \mathrm{Ci} / \mathrm{L}$ is equal to the HWVP design basis value. This value is about 25 percent above the average of the two most recent core sample analyses for 101-AZ (after allowing for decay to mid-2002) and is about 7 percent above the highest core sample analysis. The recommended value is also about 50 percent higher than Sr levels currently carried in the TWRS process flowsheet for 101-AZ. Overall, this therefore appears to be a moderately conservative design basis value without taking credit for any blending of 101-AZ. If credit is taken for blending of 101-AZ with 106-C, an additional reduction of about half or possibly more could be justified. At the recommended revised isotope levels, ${ }^{90} \mathrm{Sr}$ and ${ }^{137} \mathrm{Cs}$ produce nearly all decay heat. The recommended levels are within the preliminary canister storage facility limit of $1,000 \mathrm{~W}$ per canister for any reasonably expected glass waste loadings.

\section{Plutonium}

Plutonium isotopic limits were calculated starting with the chemical plutonium limit of $.06 \mathrm{wt} \%$ oxide, or $.016 \mathrm{~g} / \mathrm{L}$ at $31 \mathrm{G}$ oxide/L. Isotopic ratios were then calculated based on the Origen 2 predictions reported by WHC. In all cases the resulting recommended concentrations were greater than the HWVP limits. 
WHC-SD-WM-ES-370

Revision 0

\section{RECOMMENIED REVISED RFP SPECIFICATION 8 INPUT}

Specification 8: High-Level Waste Envelope Definition

This specification describes the contents of high-level waste (HLW) to be transferred to the HLW Contractor for processing during Phase I. Feed will be transferred as a waterbased slurry with the bulk of the non-volatile components present as insoluble suspended solids. Tables S8-1A and S8-1B describe the estimated average composition of selected feed components (labeled "nominal"); and the design basis minimum and maximum composition range. Nonvolatile components not listed are assumed to be below .001 g/L. Table S8-2 describes the design basis maximum feed composition for radionuclides. Table S8-3 describes the design basis range for selected physical properties of HLW feed delivered to the HLW Contractor. Feed will be delivered to the HLW Contractor by pipeline in batches and all design basis limits apply to individual batches. The HLW plant shall be designed and permitted (including safety analyses) to process feeds within the design basis ranges.

Table S8-1C provides operating basis limits for selected feed components. It may be assumed that each batch transferred will be within the operating basis limits for purposes of operational planning (glass quantity estimates, operating duration estimates, related cost estimates, etc.). Design basis limits should be used as operating basis limits for components and properties not shown in Table S8-1C. It is expected that as better data become available, the operating basis range will be narrowed, and additional components or properties may be added. Individual batches will vary from the nominal composition, and it is expected that the nominal composition will be updated periodically in the future as improved data become available. 
Reconamended Table S8-1A. Estimated Composition of Pretreated Feed(s).

\begin{tabular}{|c|c|c|c|c|c|c|c|}
\hline \multirow{2}{*}{$\begin{array}{l}\text { Non- } \\
\text { volatile } \\
\text { element }\end{array}$} & \multicolumn{3}{|c|}{$\mathrm{g} / \mathrm{L}$} & \multirow{2}{*}{$\begin{array}{l}\text { Non- } \\
\text { volatile } \\
\text { element }\end{array}$} & \multicolumn{3}{|c|}{$\mathrm{g} / \mathrm{L}$} \\
\hline & Nominal & Minimum & Maximum & & Nominal & Minimum & Maximum \\
\hline $\mathrm{Ag}$ & 0.04 & NE & 0.17 & $\mathrm{Li}$ & 0.002 & NE & 0.043 \\
\hline Al & 3.1 & 0.33 & 5.3 & & & & \\
\hline Am & $\mathrm{NE}$ & NE & 0.02 & & & & \\
\hline As & 0.02 & $\mathbf{N E}$ & 0.05 & & & & \\
\hline B & 0.02 & NE & 0.4 & & & & \\
\hline $\mathrm{Ba}$ & 0.2 & NE & 1.4 & K & .17 & NE & 0.41 \\
\hline $\mathrm{Be}$ & $\mathrm{NE}$ & $\mathbf{N E}$ & 0.02 & $\mathrm{La}$ & 0.14 & NE & 0.8 \\
\hline $\mathrm{Bi}$ & NE & NE & 0.86 & $\mathrm{Mg}$ & 0.24 & $\mathrm{NE}$ & 0.65 \\
\hline $\mathrm{Ca}$ & 0.50 & NE & 2.2 & $\mathrm{Mn}$ & 0.2 & $\mathrm{NE}$ & 2 \\
\hline $\mathrm{Cd}$ & 0.4 & $\mathrm{NE}$ & 1.4 & Mo & 0.003 & NE & 0.2 \\
\hline $\mathrm{Ce}$ & 0.034 & NE & 0.25 & $\mathrm{Na}$ & 4.6 & 1.0 & 9.2 \\
\hline $\mathrm{Cr}$ & 0.08 & NE & 0.42 & $\mathrm{Nb}$ & $\mathrm{NE}$ & NE & 0.003 \\
\hline Cs & NE & NE & 0.18 & Nd & 0.11 & NE & 0.53 \\
\hline $\mathrm{Cu}$ & 0.02 & NE & 0.15 & $\mathrm{Ni}$ & 0.26 & NE & 1.0 \\
\hline Dy & 0.002 & $\mathrm{NE}$ & 0.008 & $\mathrm{~Np}$ & $\mathrm{NE}$ & $\mathrm{NE}$ & 0.03 \\
\hline Co & .044 & NE & 0.14 & $\mathbf{P}$ & 0.14 & NE & 0.54 \\
\hline Eu & NE & $\mathrm{NE}$ & 0.005 & $\mathbf{P b}$ & 0.1 & NE & 0.34 \\
\hline $\mathrm{F}$ & 0.045 & $\mathrm{NE}$ & 1.1 & $\mathbf{P d}$ & $\mathrm{NE}$ & NE & 0.04 \\
\hline $\mathrm{Fe}$ & 5.6 & 1.7 & 13 & Pm & NE & NE & 0.03 \\
\hline Gd & NE & $\mathrm{NE}$ & 0.003 & Pr & $\mathrm{NE}$ & NE & 0.11 \\
\hline $\mathrm{Hg}$ & $\mathbf{N E}$ & $\mathrm{NE}$ & 0.03 & & & & \\
\hline
\end{tabular}




\begin{tabular}{|c|c|c|c|}
\hline GGL & 0 & EN & ${ }^{\varepsilon} \mathrm{HN}$ \\
\hline Gg. & 0 & EN & ND \\
\hline$t^{\cdot} \varepsilon$ & 0 & $\varepsilon 0$ & OOL \\
\hline \multirow{2}{*}{$\begin{array}{c}\left({ }^{(} \mathrm{ON} / /^{2} \mathrm{ON}[\mathrm{E} 30\}\right) \\
\tau^{*} \mathrm{Il}\end{array}$} & 0 & $\varepsilon^{\circ} 0$ & $-{ }^{-5} \mathrm{ON}$ \\
\hline & 0 & $8^{\circ} \mathrm{I}$ & $-{ }^{2} \mathrm{ON}$ \\
\hline$\varepsilon .6$ & $\nabla L^{\circ} 0$ & $t \cdot \tau$ & ${ }^{8} 00$ \\
\hline $\mathrm{I}^{\circ} 0$ & 0 & I0.0 & Iอ \\
\hline unturxew & umunuis & [EuाயON & \multirow[b]{2}{*}{ 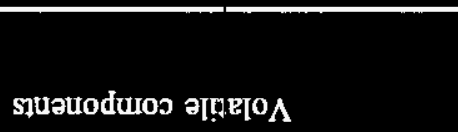 } \\
\hline & $7 / 8$ & & \\
\hline
\end{tabular}

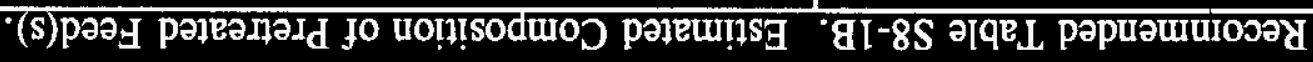

\begin{tabular}{|c|c|c|c|c|c|c|c|}
\hline 9.6 & IN & $\varepsilon 6^{\circ} 0$ & $I Z$ & $800^{\circ} 0$ & IN & ELN & eI \\
\hline$\varepsilon I^{\circ} 0$ & EN & $110 \%$ & uZ & $9 I^{\circ} 0$ & EN & $\angle I C^{\circ} 0$ & IS \\
\hline SO:0 & $\mathrm{EN}$ & IN & $\boldsymbol{X}$ & I I $0^{\circ} 0$ & EN & EIN & us \\
\hline$\vdash \angle 0^{\circ} 0$ & $\mathbf{B N}$ & IN & $M$ & $\varepsilon S 0^{\circ} 0$ & IN & EIN & us \\
\hline $10 \%$ & 当 & $\mathrm{I} 00^{\circ} 0$ & $\Lambda$ & $8^{\circ} \mathrm{S}$ & EN & $t \cdot z$ & !S \\
\hline$z^{\prime} t$ & IN & $\downarrow \varepsilon^{\circ} 0$ & ก & $91^{\circ} 0$ & EN & scio & शS \\
\hline $9 I^{\circ} 0$ & IN & $20^{\circ} 0$ & पL & $9 z^{\circ} 0$ & EN & $\forall 0^{\circ} 0$ & qS \\
\hline$+1 \%$ & EN & EN & U & $s 2^{\circ} 0$ & $\mathbf{E N}$ & $80^{\circ} 0$ & $\mathbf{S}$ \\
\hline$\nabla^{*} 0$ & IN & $10^{\circ} 0$ & !L & II 0 & EN & SOO & ny \\
\hline $60^{\circ} 0$ & GN & $9 \varepsilon 0^{\circ} 0$ & गL & $50^{\circ} 0$ & IN & $\$ I 00$ & पष \\
\hline $80^{\circ} 0$ & $\mathbf{E N}$ & IN & गL & 900 & EN & EIN & 98 \\
\hline$\varepsilon 0^{\circ} 0$ & EN & $200^{\circ} 0$ & әу & 9100 & $\mathbf{I N}$ & EIN & $n_{d}$ \\
\hline unu!x XeW & umutu!u!W & [EuฺUON & \multirow{2}{*}{ 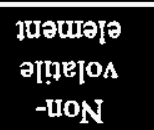 } & unumXej & unumu!h & [Eu!̣uoN & \multirow{2}{*}{ 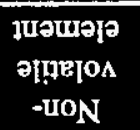 } \\
\hline \multicolumn{3}{|c|}{$7 / 8$} & & \multicolumn{3}{|c|}{$7 / 8$} & \\
\hline
\end{tabular}

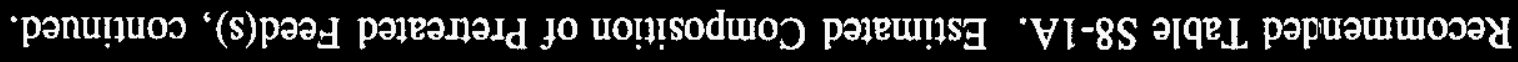


WHC-SD-WM-ES-370

Revision 0

Recommended Table S8-1C Operating Basis Feed Limits

\begin{tabular}{lcl}
\multicolumn{2}{c}{ Component } & \multicolumn{2}{c}{$\mathrm{g} / \mathrm{L}$} \\
\cline { 2 - 3 } & Minimum & Maximum \\
$\mathrm{Al}$ & 1.3 & 4.3 \\
$\mathrm{Cr}$ & 0 & 0.21 \\
$\mathrm{Fe}$ & 2.6 & 8.9 \\
$\mathrm{Na}$ & 2.3 & 6.0 \\
$\mathrm{Ni}$ & 0.0 .5 & 0.73 \\
$\mathrm{~S}$ & 0 & 0.2
\end{tabular}

Notes (Tables S8-1A, B, and C):

1. Cocosatrition values given in this table are based on an overall waste concentration of $31 \mathrm{~g}$ non-volatile oxides/L. Concentration values given in this table will vary in direct proportion to actual overall concentration of Non-volatile oxides.

${ }^{2}$ Non-volatile trace components with concentrations below $0.001 \mathrm{~g} / \mathrm{L}$ are not shown.

${ }^{3}$ Maxinum concentrations of radioisotopes are shown in Table S8-2.

${ }^{4} \mathrm{NE}=$ Not Estimate; $\mathrm{TOC}=$ Total Organic Carbon; TBD $=$ To Be Determined. 
WHC-SD-WM-ES-370

Revision 0

Recommended Table S8-2. Maximum Radionuclide Composition of Pretreated Feed.

\begin{tabular}{|c|c|c|c|c|c|}
\hline Isotope & $\mathrm{Ci} / \mathrm{L}$ & Isotope & $\mathrm{Ci} / \mathrm{L}$ & Isotope & $\mathrm{Ci} / \mathrm{L}$ \\
\hline${ }^{3} \mathrm{H}$ & $2 \mathrm{E}-05$ & ${ }^{113} \mathrm{Sn}$ & $1.88 \mathrm{E}-06$ & ${ }^{147} \mathrm{Pm}$ & $1.6 \mathrm{E}-01$ \\
\hline${ }^{14} \mathrm{C}$ & $2 \mathrm{E}-06$ & ${ }^{115 m} \mathrm{Cd}$ & 6.55 E-10 & & \\
\hline${ }^{55} \mathrm{Fe}$ & $1.0 \mathrm{E}-03$ & ${ }^{119 m} \mathrm{Sn}$ & $1.0 \mathrm{E}-08$ & ${ }^{151} \mathrm{Sm}$ & 9.3 E-02 \\
\hline${ }^{59} \mathrm{Ni}$ & 1.4 E-05 & ${ }^{121 \mathrm{~m}} \mathrm{Sn}$ & $9.0 \mathrm{E}-06$ & ${ }^{152} \mathrm{Eu}$ & $1.5 \mathrm{E}-04$ \\
\hline${ }^{60} \mathrm{Co}$ & $3.0 \mathrm{E}-03$ & & & & \\
\hline${ }^{63} \mathrm{Ni}$ & $1.6 \mathrm{E}-03$ & ${ }^{126} \mathrm{Sn}$ & $4.8 \mathrm{E}-05$ & ${ }^{154} \mathrm{Eu}$ & $1.6 \mathrm{E}-02$ \\
\hline \multirow[t]{2}{*}{${ }^{79} \mathrm{Se}$} & 4.2 E-07 & ${ }^{124} \mathrm{Sb}$ & $2.61 \mathrm{E}-09$ & ${ }^{155} \mathrm{Eu}$ & $9.0 \mathrm{E}-03$ \\
\hline & & ${ }^{126} \mathrm{Sb}$ & $4.83 \mathrm{E}-06$ & & \\
\hline${ }^{90} \mathrm{Sr}$ & $3.1 \mathrm{E}+00$ & ${ }^{126 \mathrm{~m}} \mathrm{Sb}$ & $3.43 \mathrm{E}-05$ & ${ }^{234} \mathrm{U}$ & $7.7 \mathrm{E}-07$ \\
\hline \multirow[t]{2}{*}{${ }^{90} \mathrm{Y}$} & $3.1 \mathrm{E}+00$ & ${ }^{125} \mathrm{Sb}$ & $1.0 \mathrm{E}-02$ & ${ }^{235} \mathrm{U}$ & $3.2 \mathrm{E}-08$ \\
\hline & & ${ }^{125 \mathrm{~m}} \mathrm{Te}$ & $3.0 \mathrm{E}-03$ & ${ }^{236} \mathrm{U}$ & 8.2 E-08 \\
\hline${ }^{93 \mathrm{~m}} \mathrm{Nb}$ & $8.7 \mathrm{E}-05$ & & & ${ }^{238} \mathrm{U}$ & $5.8 \mathrm{E}-07$ \\
\hline \multirow[t]{3}{*}{${ }^{93} \mathrm{Zr}$} & 1.4 E-04 & & & ${ }^{237} \mathrm{~Np}$ & $2.3 \mathrm{E}-05$ \\
\hline & & & & ${ }^{238} \mathrm{Pu}$ & $1.1 \mathrm{E}-04$ \\
\hline & & & & ${ }^{239} \mathrm{Pu}$ & $9.5 \mathrm{E}-04$ \\
\hline \multirow[t]{3}{*}{${ }^{99} \mathrm{Tc}$} & $4.5 \mathrm{E}-03$ & ${ }^{129} \mathrm{I}$ & $9.0 \mathrm{E}-08$ & ${ }^{240} \mathrm{Pu}$ & $2.6 \mathrm{E}-04$ \\
\hline & & ${ }^{134} \mathrm{Cs}$ & $6.8 \mathrm{E}-03$ & ${ }^{241} \mathrm{Pu}$ & $6.9 \mathrm{E}-03$ \\
\hline & & ${ }^{135} \mathrm{Cs}$ & $3.0 \mathrm{E}-05$ & ${ }^{242} \mathrm{Pu}$ & $7.1 \mathrm{E}-08$ \\
\hline${ }^{106} \mathrm{Ru}$ & 2.0 E-04 & ${ }^{137} \mathrm{Cs}$ & $3.0 \mathrm{E}+00$ & ${ }^{24 t} \mathrm{Am}$ & $4.3 \mathrm{E}-02$ \\
\hline${ }^{106} \mathrm{Rh}$ & $2.0 \mathrm{E}-04$ & ${ }^{137}{ }_{m} \mathrm{Ba}$ & $3.0 \mathrm{E}+\infty 0$ & ${ }^{242} \mathrm{Am}$ & $3.1 \mathrm{E}-05$ \\
\hline${ }^{107} \mathrm{Pd}$ & $4.0 \mathrm{E}-06$ & & & ${ }^{242 \mathrm{~m}} \mathrm{Am}$ & $3.2 \mathrm{E}-05$ \\
\hline${ }^{110 m} \mathrm{Ag}$ & 1.0 E-08 & ${ }^{144} \mathrm{Ce}$ & $1.0 \mathrm{E}-04$ & ${ }^{243} \mathrm{Am}$ & 5.0 E-06 \\
\hline${ }^{113 m} \mathrm{Cd}$ & 1.09 E-03 & ${ }^{144} \mathrm{Pr}$ & 1.0 E-04 & ${ }^{242} \mathrm{Cm}$ & $3.7 \mathrm{E}-05$ \\
\hline${ }^{113 m} / n$ & $1.88 \mathrm{E}-06$ & ${ }^{144 m} \mathrm{Pr}$ & $1.0 \mathrm{E}-07$ & ${ }^{244} \mathrm{Cm}$ & $9.3 \mathrm{E}-04$ \\
\hline
\end{tabular}

${ }^{\text {t}}$ Radionuclide composition values given in this table are based on an overall waste concentration of $31 \mathrm{~g}$ non-volatile oxides/L. Maximum values vary in direct proportion to actual concentration of non-volatile oxides.

${ }^{2}$ Some decay products such as radon from uranium decay not shown. Trace isotopes below $1 \mathrm{E}-09 \mathrm{Ci} / \mathrm{L}$ not shown. 
WHC-SD-WM-ES-370

Revision 0

Recommended Table S8-3. High-Level Waste Feed Design Basis Physical Properties.

\begin{tabular}{|c|c|c|}
\hline Property & Nominal & Design Range \\
\hline Total solids (wt \%) & 4.2 & $2.5-13$ \\
\hline Total non-volatile oxides $(\mathrm{g} / \mathrm{L}$ ) & 31 & $25-100$ \\
\hline Slurry density $(\mathrm{g} / \mathrm{mL})$ & 1.03 & $1.02-1.10$ \\
\hline Settled solids (vol\%) & 12 & 7-95 \\
\hline \multicolumn{3}{|l|}{ Apparent viscosity (cP at $25^{\circ} \mathrm{C}$ ) } \\
\hline at $10 \mathrm{~s}^{-1}$ (50 rpm agitator $)$ & 50 & 6-94 \\
\hline at $25 \mathrm{~s}^{-1}$ (130 $\mathrm{rpm}$ agitator) & 25 & $3-50$ \\
\hline at $183 \mathrm{~s}^{-1}$ & 25 & $1-50$ \\
\hline Yield stress, $\left(\right.$ dyne $\left./ \mathrm{cm}^{2}\right)$ & 25 & $1-150$ \\
\hline $\begin{array}{l}\text { Settled solids shear strength } 2 \text { days settling } \\
\left(\text { dyne } / \mathrm{cm}^{2}\right)\end{array}$ & 50 & $20-200$ \\
\hline Heat capacity $\left(\mathrm{cal} / \mathrm{g}-{ }^{\circ} \mathrm{C}\right.$ ) & .88 & $0.79-0.97$ \\
\hline $\mathrm{pH}$ & 12 & $>10$ \\
\hline
\end{tabular}

$\mathrm{a}=$ Dried at approximately $100^{\circ} \mathrm{C}$. 
WHC-SD-WM-ES-370

Revision 0

\section{REFERENCES}

Bacon, R. F., 1995, Double-Shell Tank Waste Consolidation and Retrieval Planning Base Case, 75510-95-017 (August 30, 1995), Westinghouse Hanford Company, Richland, Washington.

DOE, 1995, TWRS Privatization Request for Proposals - Draft, DE-RP06-96RL13308, U.S. Department of Energy, Richland Operations, Richland, Washington.

McCown, J. J., 1988, Final Report on Single-Shell Tank Sample (241-C-106), memo to R. S. Wegeng (August 31, 1988), Pacific Northwest Laboratory, Richland, Washington. 
WHC-SD-WM-ES-370

Revision 0

This page intentionally left blank. 
WHC-SD-WM-ES-370

Revision 0

APPENDIX C

ALTERNATIVE HIGH-LEVEL WASTE GLASS FORMULATIONS AND IMPACTS OF SLUDGE WASHING ALTERNATIVES

DATA SUMMARY TABLES

C-1 
WHC-SD-WM-ES-370

Revision 0

This page intentionally left blank.

C-2 
WHC-SD-WM-ES-370

Revision 0

APPENDIX C

\section{ALTERNATIVE HIGH-LEVEL WASTE GLASS FORMULATIONS AND IMPACTS OF SLUDGE WASHING ALTERNATIVES}

\section{DATA SUMMARY TABLES}

Chapter 4.0 of this document discusses the relationships between the high-level waste (HLW) glass formulation and the pretreatment strategy. The following data tables (Tables C-1 through C-10) show the estimated glass compositions assuming different retrieval efficiencies (minimum and maximum retrieval), alternative glass formulations (CVS and HWVP), the "no consolidation" case (processing individual tanks), and the effects of different pretreatment strategies (i.e., dilute caustic versus caustic washing, multiple washes, etc.). In the top portion of each table, the mass of insoluble solids and equivalent waste oxides, the number of reference HLW canisters, the waste oxide loading, and the limiting glass component is presented. The highlighted areas in each of the tables indicate the limiting component(s) in the glass. Water washing twice (column 6 ) is considered to be the preferred case for each of the tables. 
WHC-SD-WM-ES-370

Revision 0

Table C-1. Low Tamparature CVs Clase Compoeition - Minimum Ratrieval, Baselline (Becon $19 e s)$ Consolidation

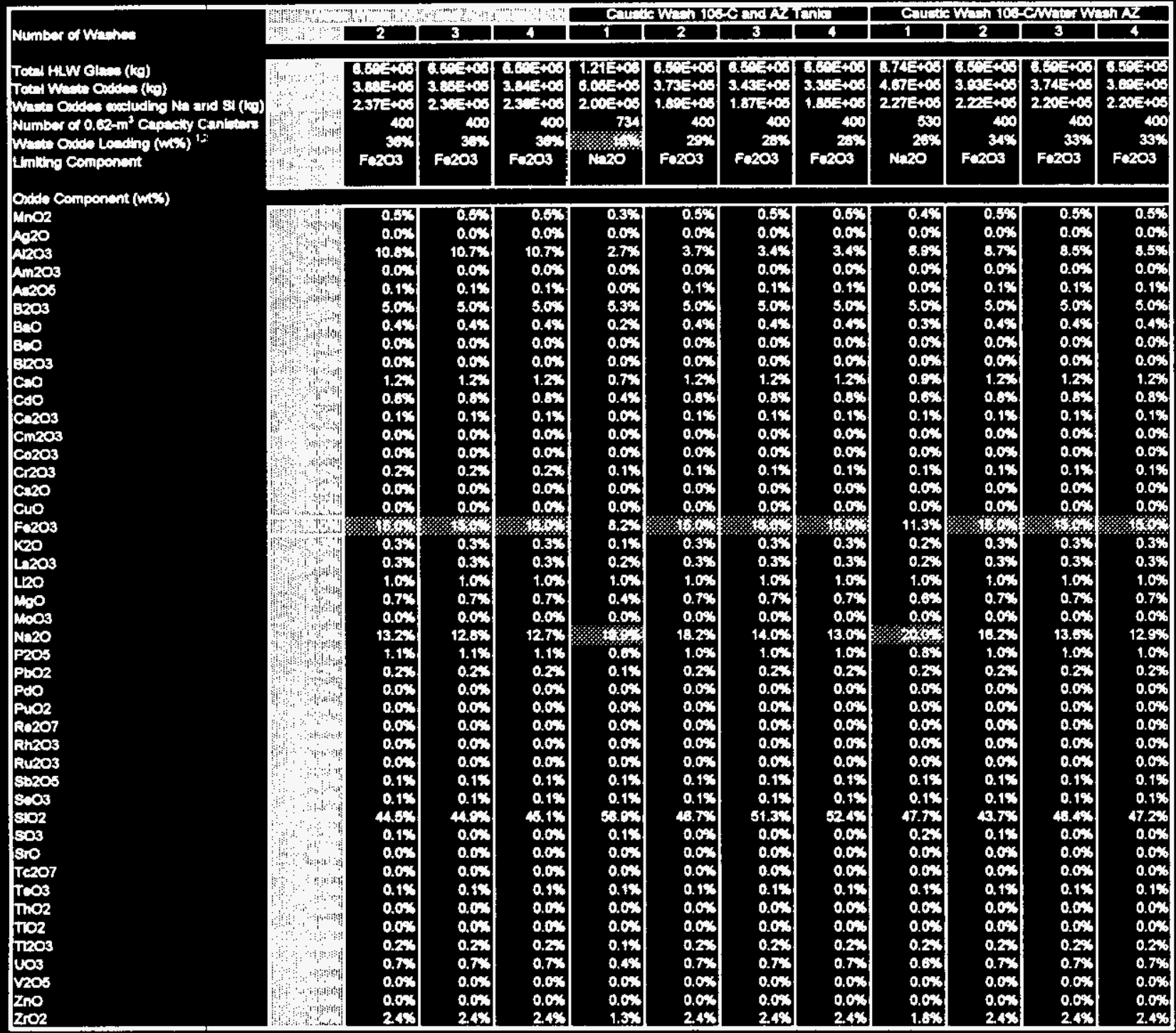

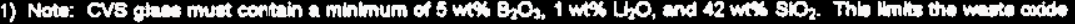

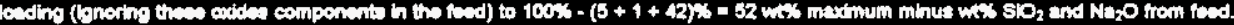

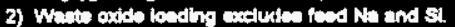




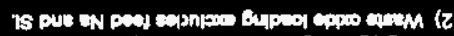

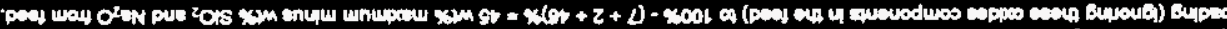

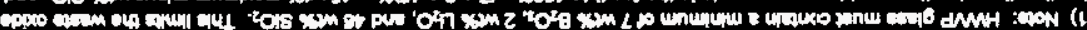

\begin{tabular}{|c|c|c|c|c|c|c|c|c|c|c|c|c|}
\hline 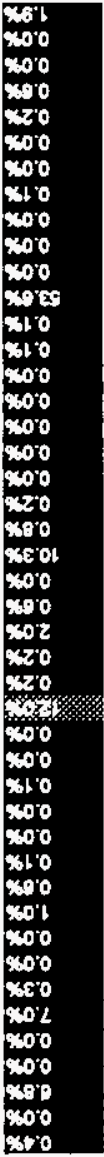 & 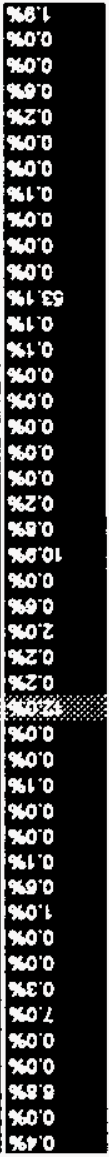 & 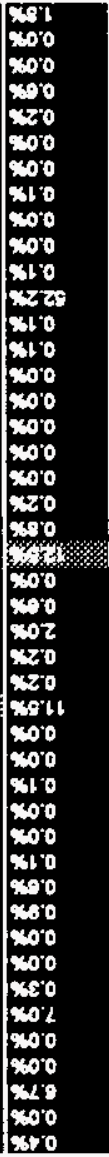 & 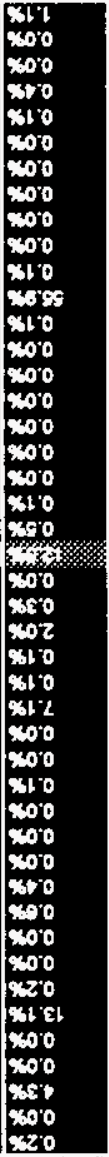 & 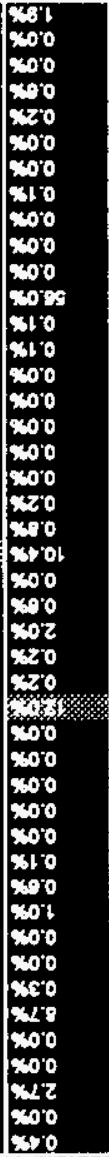 & 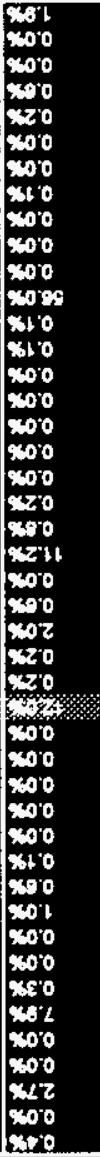 & 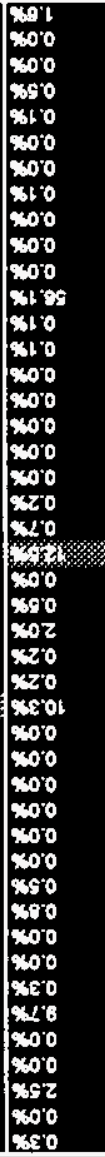 & 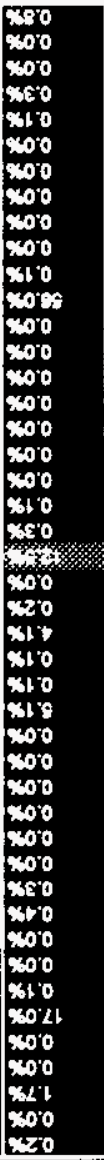 & 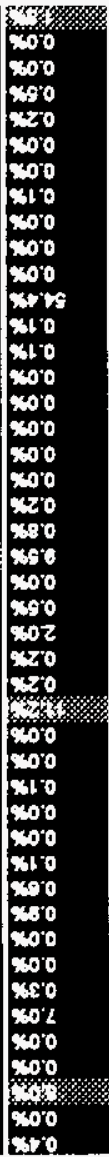 & 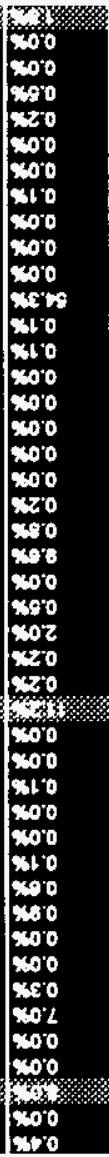 & 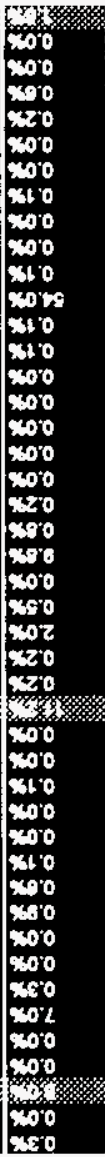 & (1) & 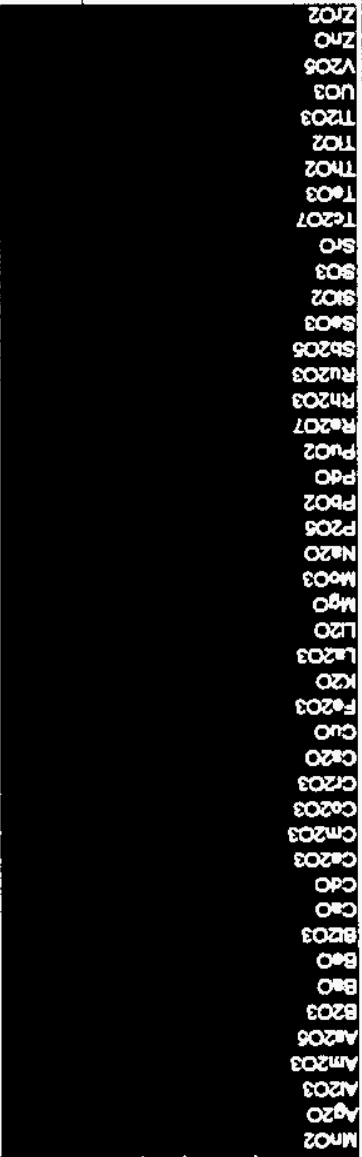 \\
\hline 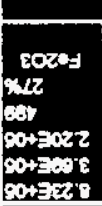 & 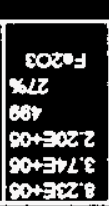 & 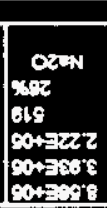 & 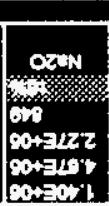 & 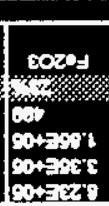 & 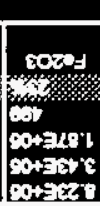 & 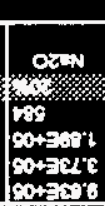 & 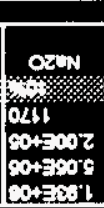 & 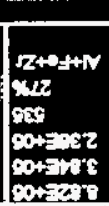 & 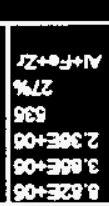 & 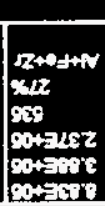 & का का & 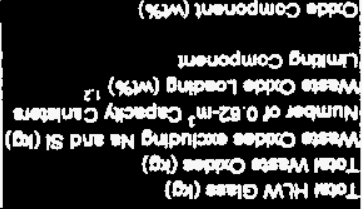 \\
\hline$\frac{1}{44}$ & $\frac{\varepsilon}{1}$ & $\frac{2}{12}$ & $\frac{1}{120}$ & 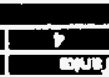 & $\frac{\varepsilon}{17}$ & $\frac{z}{4 n}$ & 1 & $\mathbf{p}$ & $\varepsilon$ & 2 & & 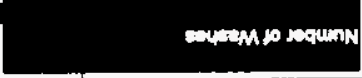 \\
\hline
\end{tabular}

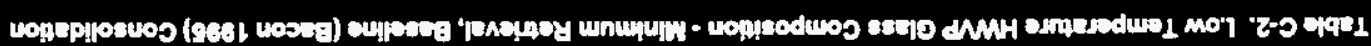

0 uoțịıว

0LE-SA-WM-GS-JHM 


\section{Revision 0}

Tabb C-3. Low Tomperature CVS Olass Compostion - Maximum Retrioval, Baselline (Bacen 19se) Consolldation

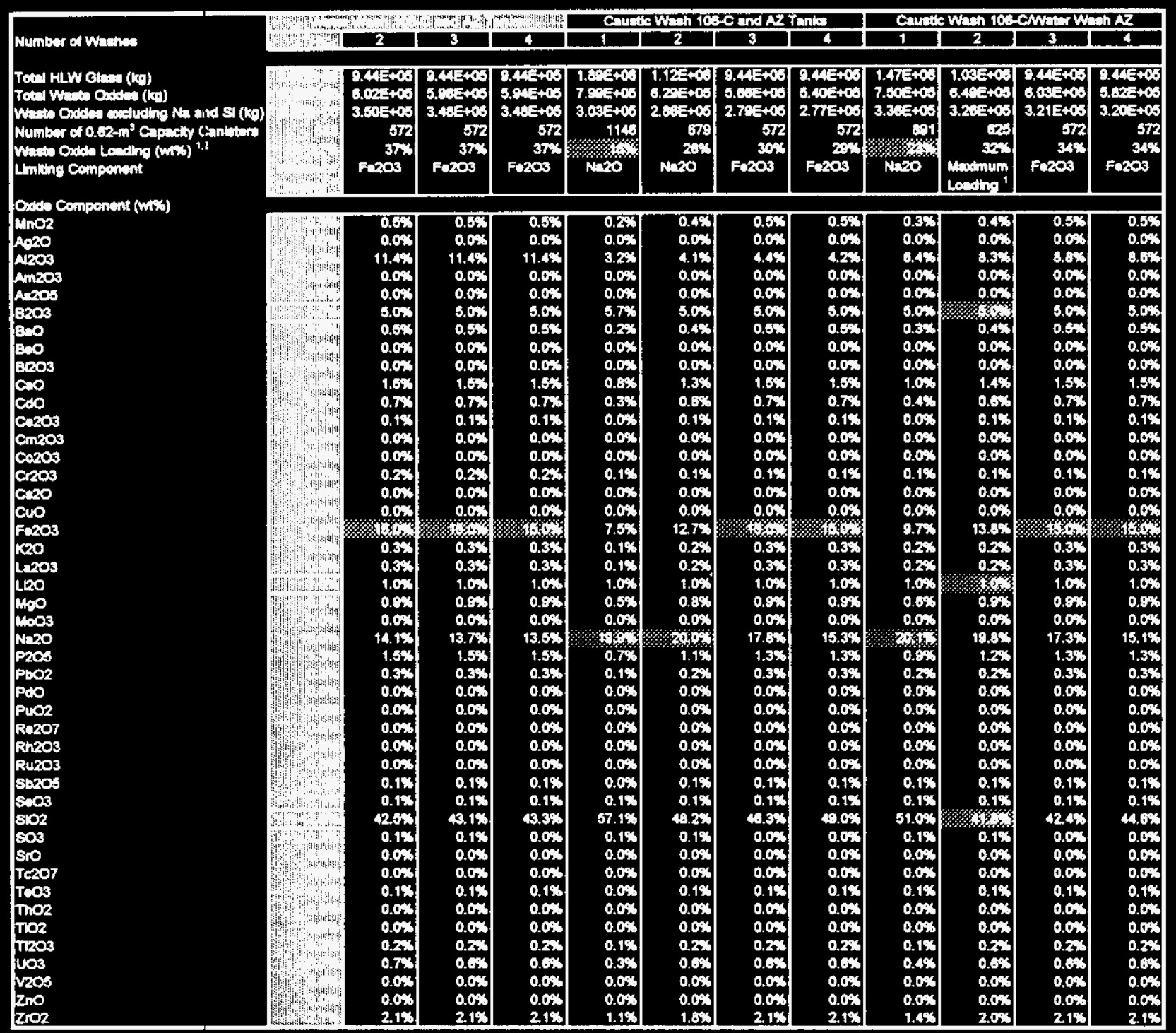

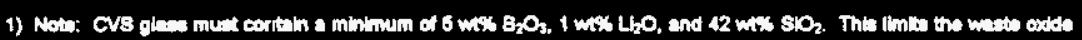

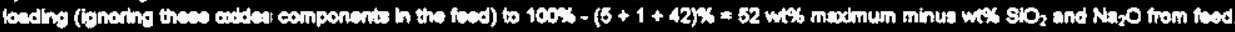

2) Wets oide loading enctustes fond the and $\mathrm{g}$ 
WHC-SD-WM-ES-370

Revision 0

Table C-4. Low Temperature HMVP Giast Composition - Maximum Rotrisval, Beseline (Becon 19es) Consolidation

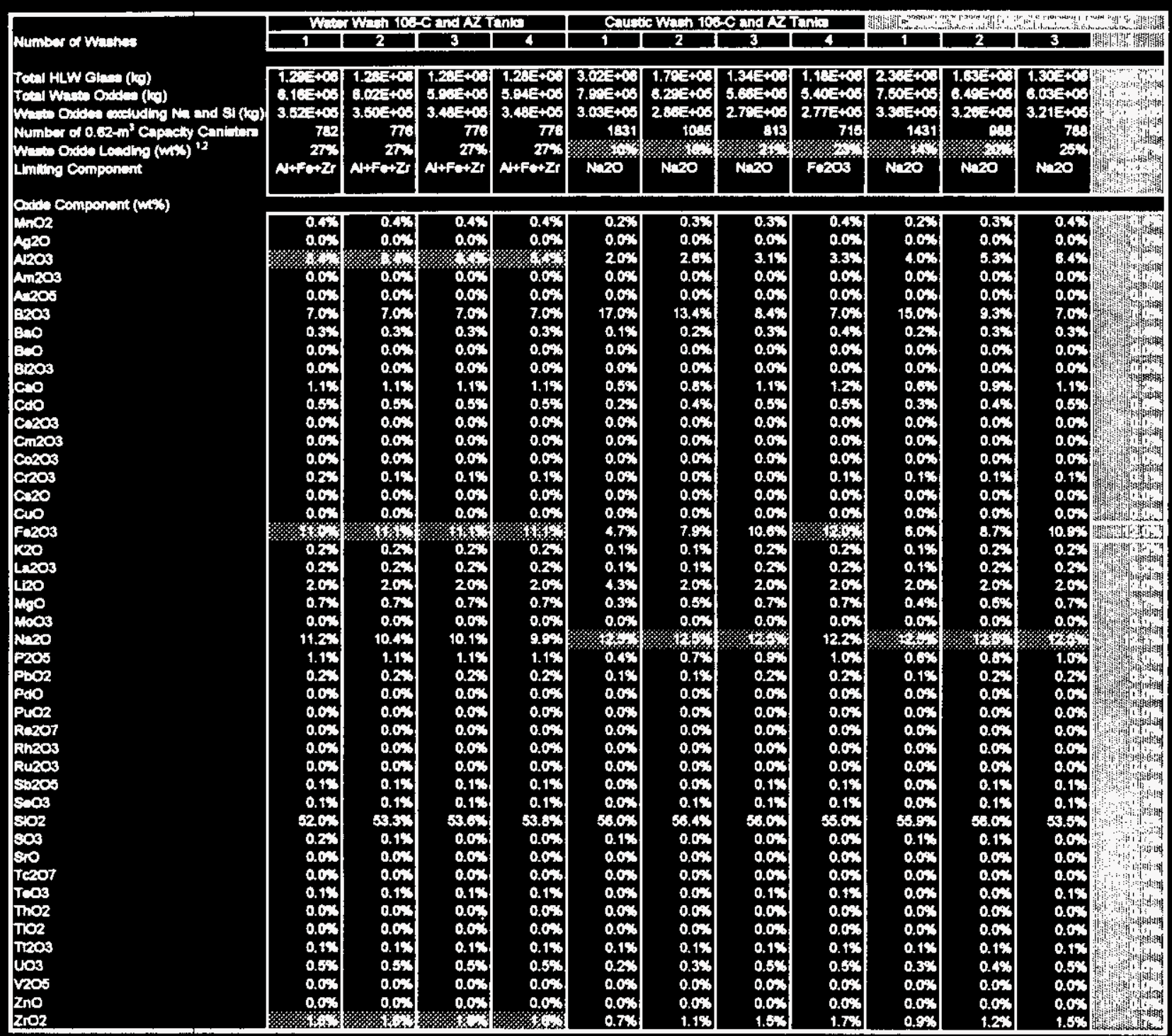

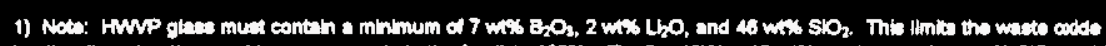

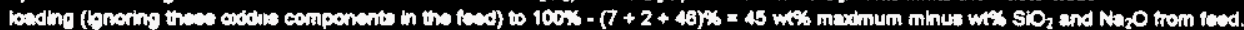

2) Wante oddo bading eveluden foed Na and $S$. 


\section{Revision 0}

Table C-5. Low Temperature CVS Class Composition - Wash 106-C (75\%) in 102-AY Separately

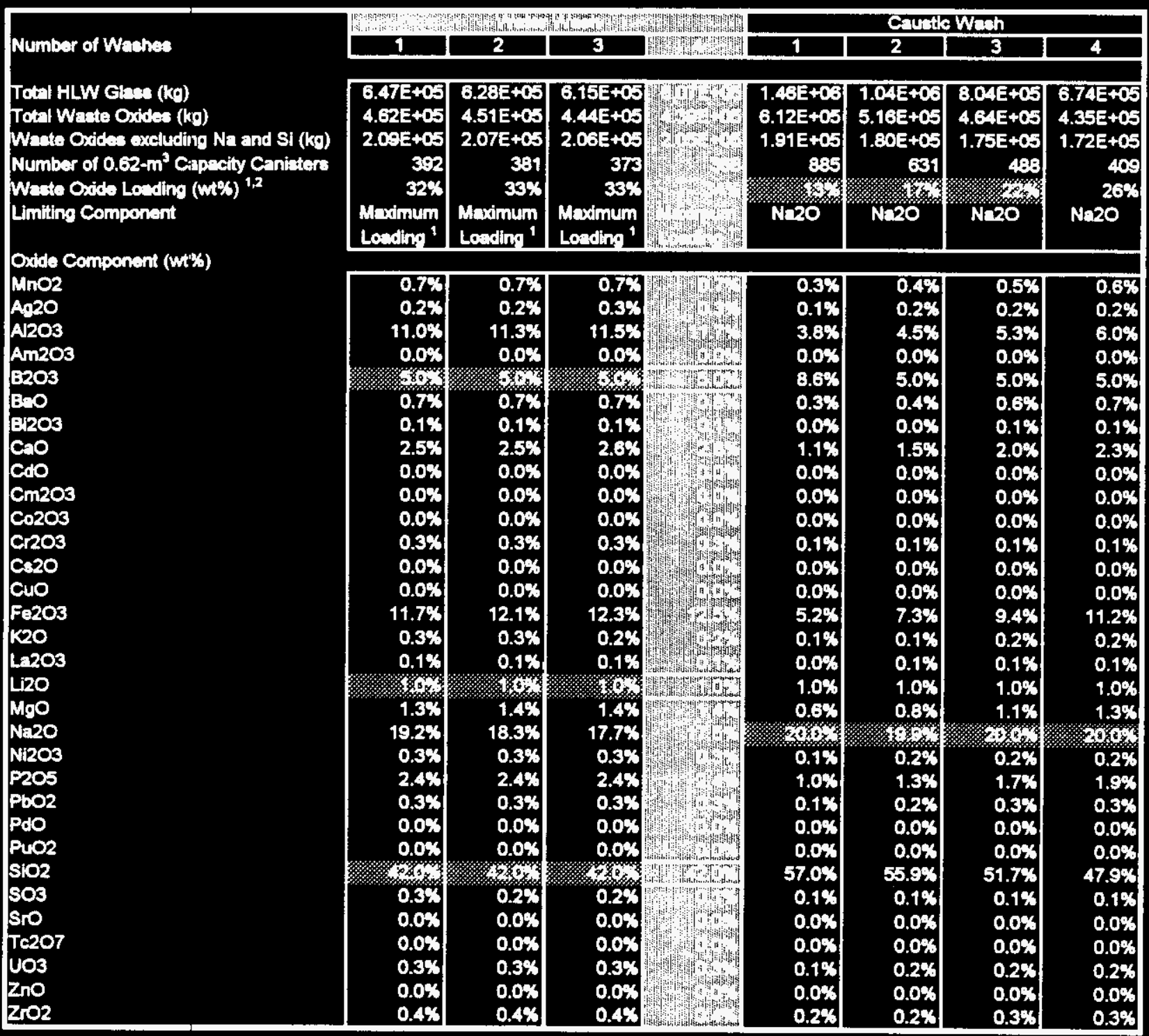

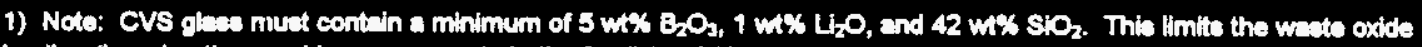
loading (ionoring these oxdse components in the foed) to $100 \%-(5+1+42) \%=52 \mathrm{w} \%$ maximum minus wh $\mathrm{siO}_{2}$ and $\mathrm{Na}_{2} \mathrm{O}$ from feed 2) Waste oxida loading excludies feod Na and SI. 
WHC-SD-WM-ES-370

Revision 0

Table C-6. Low Temperature HWMP Class Composition - Wash 106-C (75\%) in 102-AY Separately

\begin{tabular}{|c|c|c|c|c|c|c|c|c|}
\hline \multirow[b]{2}{*}{ Number of Waches } & 2? & & & & \multicolumn{4}{|c|}{ Coutic Wath } \\
\hline & 1 & 2 & 3 & & 1 & 2 & 3 & 4 \\
\hline 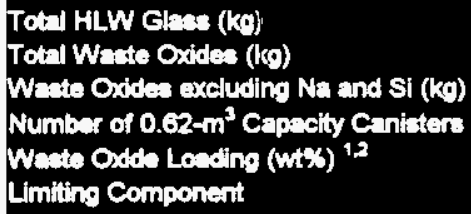 & 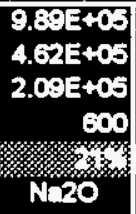 & 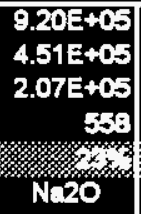 & $\begin{array}{r}8.75 E+05 \\
4.44 E+05 \\
2.06 E+05 \\
531 \\
5 \times \\
\text { Na20 }\end{array}$ & 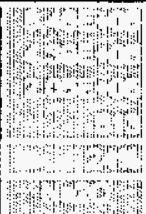 & 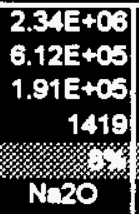 & 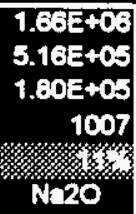 & 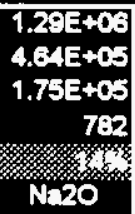 & 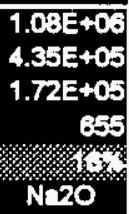 \\
\hline \multicolumn{9}{|l|}{ Oxde Component (w\%) } \\
\hline MnO2 & $0.4 \%$ & $0.5 \%$ & $0.5 \%$ & & 0.28 & $0.3 \%$ & $0.3 \%$ & $0.4 \%$ \\
\hline $\begin{array}{l}\text { A } 20 \\
\text { A2O3 }\end{array}$ & $\begin{array}{l}0.2 \% \\
7.2 \%\end{array}$ & $\begin{array}{l}0.2 \% \\
7.7 \%\end{array}$ & $\begin{array}{l}0.2 \% \\
8.1 \%\end{array}$ & & $\begin{array}{l}0.1 \% \\
2.4 \%\end{array}$ & $\begin{array}{l}0.1 \% \\
2.8 \%\end{array}$ & $\begin{array}{l}0.1 \% \\
3.3 \%\end{array}$ & $\begin{array}{l}0.1 \% \\
3.7 \%\end{array}$ \\
\hline Am203 & $0.0 \%$ & $0.0 \%$ & $0.0 \%$ & S & $0.0 \%$ & $0.0 \%$ & $0.0 \%$ & $0.0 \%$ \\
\hline 8203 & $7.9 \%$ & $7.0 \%$ & $7.0 \%$ & & $17.0 \%$ & $17.0 \%$ & $15.5 \%$ & $13.1 \%$ \\
\hline BaO & $0.5 \%$ & $0.5 \%$ & $0.5 \%$ & & $0.2 \%$ & $0.3 \%$ & $0.4 \%$ & $0.4 \%$ \\
\hline B1203 & $0.0 \%$ & $0.0 \%$ & $0.1 \%$ & & $0.0 \%$ & $0.0 \%$ & $0.0 \%$ & $0.0 \%$ \\
\hline $\mathrm{C}=0$ & $1.6 \%$ & $1.7 \%$ & $1.8 \%$ & & $0.7 \%$ & $1.0 \%$ & $1.2 \%$ & $1.5 \%$ \\
\hline CdO & $0.0 \%$ & $0.0 \%$ & $0.0 \%$ & Pfont & $0.0 \%$ & $0.0 \%$ & $0.0 \%$ & $0.0 \%$ \\
\hline $\begin{array}{l}\mathrm{Cm} 203 \\
\mathrm{C} 203\end{array}$ & $\begin{array}{l}0.0 \% \\
0.0 \%\end{array}$ & $\begin{array}{l}0.0 \% \\
0.0 \%\end{array}$ & $0.0 \%$ & " & $\begin{array}{l}0.0 \% \\
0.0 \%\end{array}$ & $0.0 \%$ & $0.0 \%$ & $\begin{array}{l}0.0 \% \\
0.0 \%\end{array}$ \\
\hline $\mathrm{Cr} 203$ & $0.2 \%$ & $0.2 \%$ & $0.2 \%$ & & $0.1 \%$ & $0.1 \%$ & $0.1 \%$ & $0.1 \%$ \\
\hline $\operatorname{Cs20}$ & $0.0 \%$ & $0.0 \%$ & $0.0 \%$ & & $0.0 \%$ & $0.0 \%$ & $0.0 \%$ & $0.0 \%$ \\
\hline CuO & $0.0 \%$ & $0.0 \%$ & $0.0 \%$ & tint & $0.0 \%$ & $0.0 \%$ & $0.0 \%$ & $0.0 \%$ \\
\hline $\mathrm{Fe} 203$ & $7.7 \%$ & $8.2 \%$ & $8.7 \%$ & & $4.0 \%$ & $4.6 \%$ & $5.9 \%$ & $7.0 \%$ \\
\hline K2O & $0.2 \%$ & $0.2 \%$ & $0.2 \%$ & & $0.1 \%$ & $0.1 \%$ & $0.1 \%$ & $0.1 \%$ \\
\hline L2203 & $0.1 \%$ & $0.1 \%$ & $0.1 \%$ & 4y & $0.0 \%$ & $0.0 \%$ & $0.1 \%$ & $0.1 \%$ \\
\hline Li2O & $2.0 \%$ & $2.0 \%$ & $2.0 \%$ & (r) & $5.4 \%$ & $3.3 \%$ & $2.0 \%$ & $2.0 \%$ \\
\hline MoO & $0.9 \%$ & $0.9 \%$ & $1.0 \%$ & If & $0.4 \%$ & $0.5 \%$ & $0.7 \%$ & $0.8 \%$ \\
\hline $\mathrm{N} 20$ & $8<x$ & $x<$ & x & HFI? & x & 繁 & 繁 8 & $8<$ \\
\hline $\mathrm{Ni2O3}$ & $0.2 \%$ & $0.2 \%$ & $0.2 \%$ & An & $0.1 \%$ & $0.1 \%$ & $0.1 \%$ & $0.2 \%$ \\
\hline P2OS & $1.6 \%$ & $1.6 \%$ & $1.7 \%$ & & $0.6 \%$ & $0.8 \%$ & $1.0 \%$ & $1.2 \%$ \\
\hline $\mathrm{PbO2}$ & $0.2 \%$ & $0.2 \%$ & 0.24 & & $0.1 x$ & $0.1 \%$ & $0.2 \%$ & $0.2 \%$ \\
\hline 10 & $0.0 \%$ & $0.0 \%$ & $0.0 \%$ & & $0.0 x$ & $0.0 \%$ & $0.0 \%$ & $0.0 \%$ \\
\hline 102 & $0.0 \%$ & $0.0 \%$ & $0.0 \times 5$ & & $0.0 \%$ & $0.0 \%$ & $0.0 \%$ & $0.0 \%$ \\
\hline 8102 & $53.0 \%$ & $55.5 \%$ & $54.5 \%$ & & $58.0 \%$ & $55.9 \%$ & $55.8 x$ & $55.9 \%$ \\
\hline 803 & $0.2 \%$ & $0.2 \%$ & $0.1 \%$ & & $0.1 \%$ & $0.1 x$ & $0.0 \%$ & $0.0 \%$ \\
\hline sro & $0.0 \%$ & $0.0 x$ & $0.0 \%$ & & $0.0 \%$ & $0.0 x$ & $0.0 \%$ & $0.0 \%$ \\
\hline Tc207 & $0.0 \%$ & $0.0 x$ & $0.0 \%$ & $78^{4}$ & $0.0 \%$ & $0.0 \%$ & $0.0 \%$ & $0.0 \%$ \\
\hline UO3 & $0.2 \%$ & $0.2 \%$ & $0.2 \%$ & & $0.1 \%$ & $0.1 \%$ & $0.1 \%$ & $0.1 \%$ \\
\hline Zno & $0.0 \%$ & $0.0 \%$ & $0.0 \%$ & W 114 & $0.0 \%$ & $0.0 \%$ & $0.0 \%$ & $0.0 \%$ \\
\hline 2,02 & $0.2 \%$ & $0.2 \%$ & $0.3 \%$ & 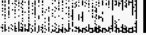 & $0.1 \%$ & $0.1 \%$ & $0.2 \%$ & $0.2 \%$ \\
\hline
\end{tabular}

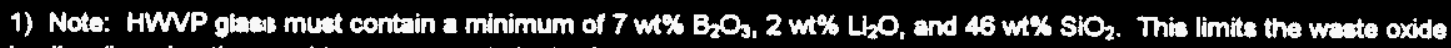
lading (ignoing theas oxides components in the feed) to $100 \%-(7+2+46) \%=45$ w\% maximum minus w\% $\mathrm{SiO}_{2}$ and $\mathrm{Na}_{2} \mathrm{O}$ from feed 2) Wacte oxdde loading excludee feed Na and Si. 
Revision 0

Table C-7. Low Temperoture CVS Class Composition - Wach 101-AZ Separately

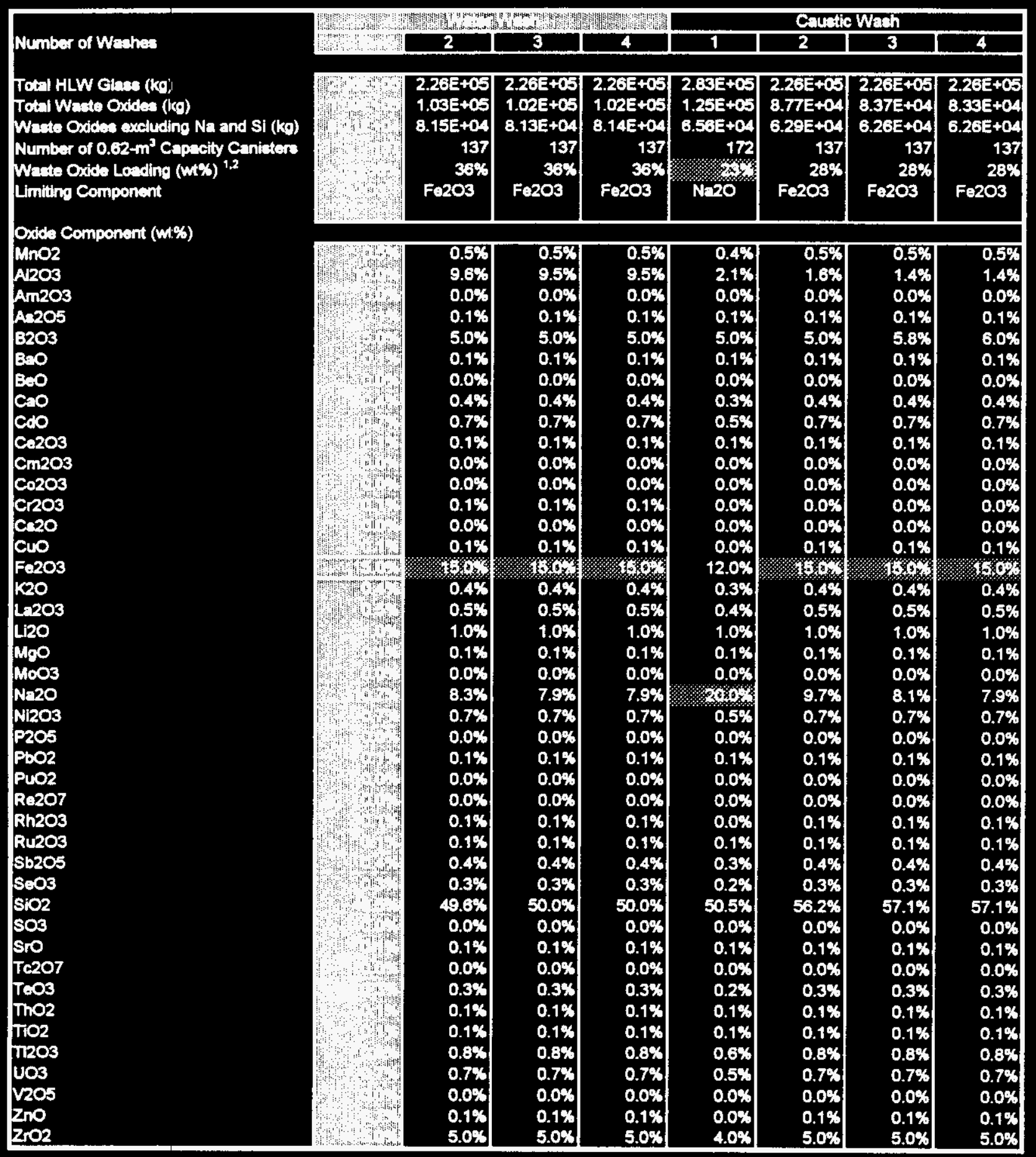

1) Note: CVS gase inuat contain a minimum of $5 \mathrm{w} \% \mathrm{~B}_{2} \mathrm{O}_{3}, 1 \mathrm{w} \% \mathrm{~L}_{2} \mathrm{O}$, and $42 \mathrm{w} \% \mathrm{SKO}_{2}$. This limite the wate oxide loading (tenoring theas oxides components in the feed) to $100 \%-(5+1+42) \%=52$ wt\% maximum minus wt\% $\mathrm{SiO}_{2}$ and $\mathrm{Na}_{2} \mathrm{O}$ from feed 2) Waste oxide looding excludes foed Na and $\mathrm{SI}$. 
WHC-SD-WM-ES-370

Revision 0

Table C-8. Low Temperature HWVP Glass Composition - Wash 101-AZ Separately

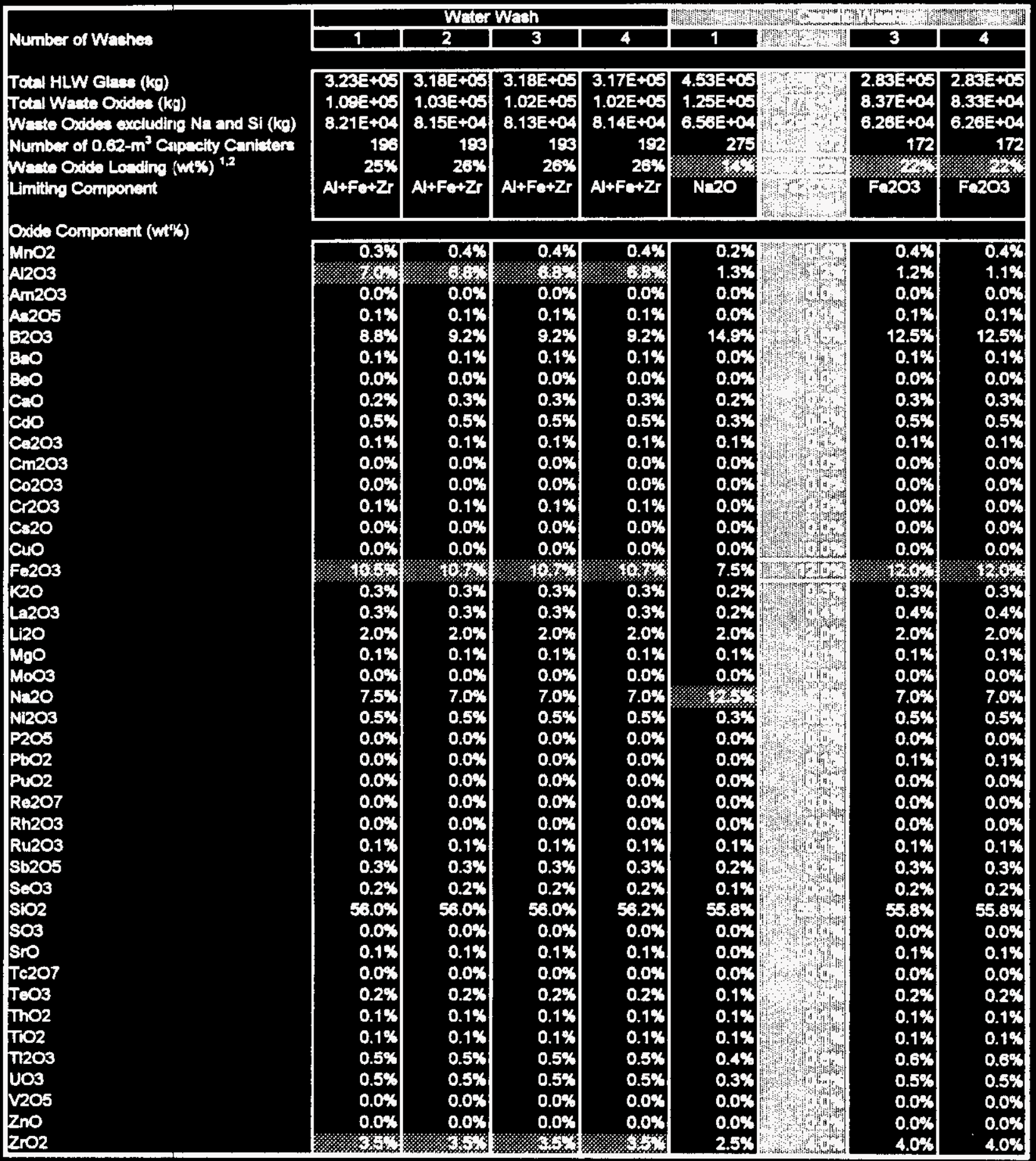

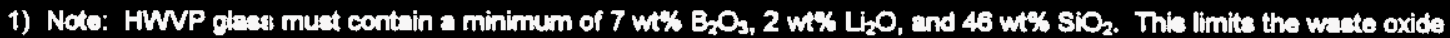
loading (ienoring these oxides componants in the feed) to $100 \%-(7+2+46) \%=45$ wt\% maximum minus wt\% $\mathrm{siO}_{2}$ and $\mathrm{Na}_{2} \mathrm{O}$ from feed 2) Waste oxdde loading excludes feed Na and Si. 
WHC-SD-WM-ES-370

Revision 0

Table C-9. Low Tempercture CVS Olass Composition - Wash 102-AZ Separately

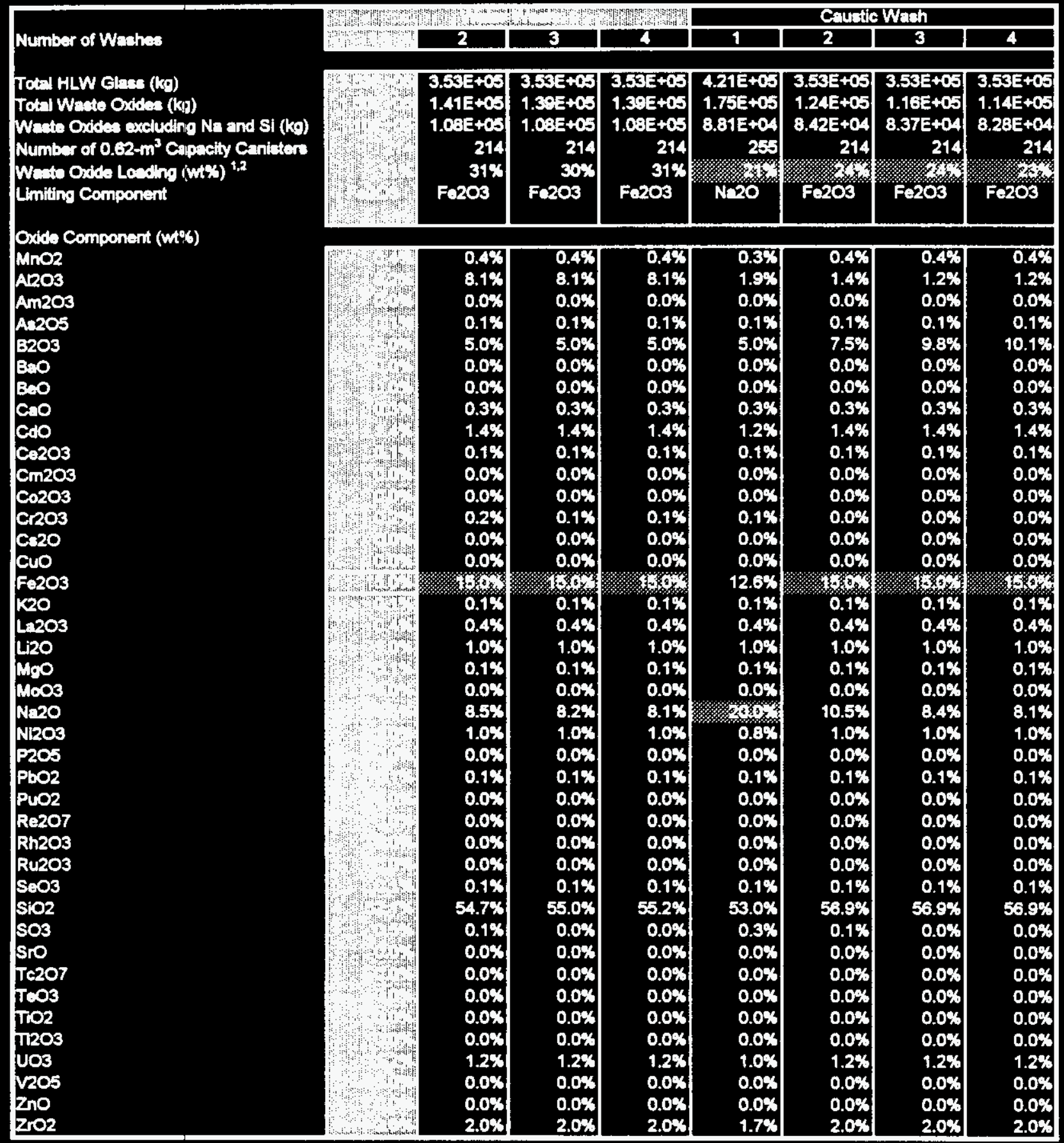

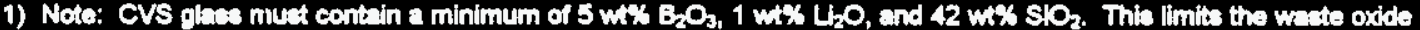
loading (ignoring these oxdee components in the feed) to $100 \%-(5+1+42) \%=52$ w* maximum minus w\% siO $\mathrm{O}_{2}$ and $\mathrm{Na}_{2} \mathrm{O}$ from feed 2) Wacte oxide loading excludes foed Na and $S$. 
Table 6-10. Low Temperature HWNP Class Composition - Wash 102-AZ Separately

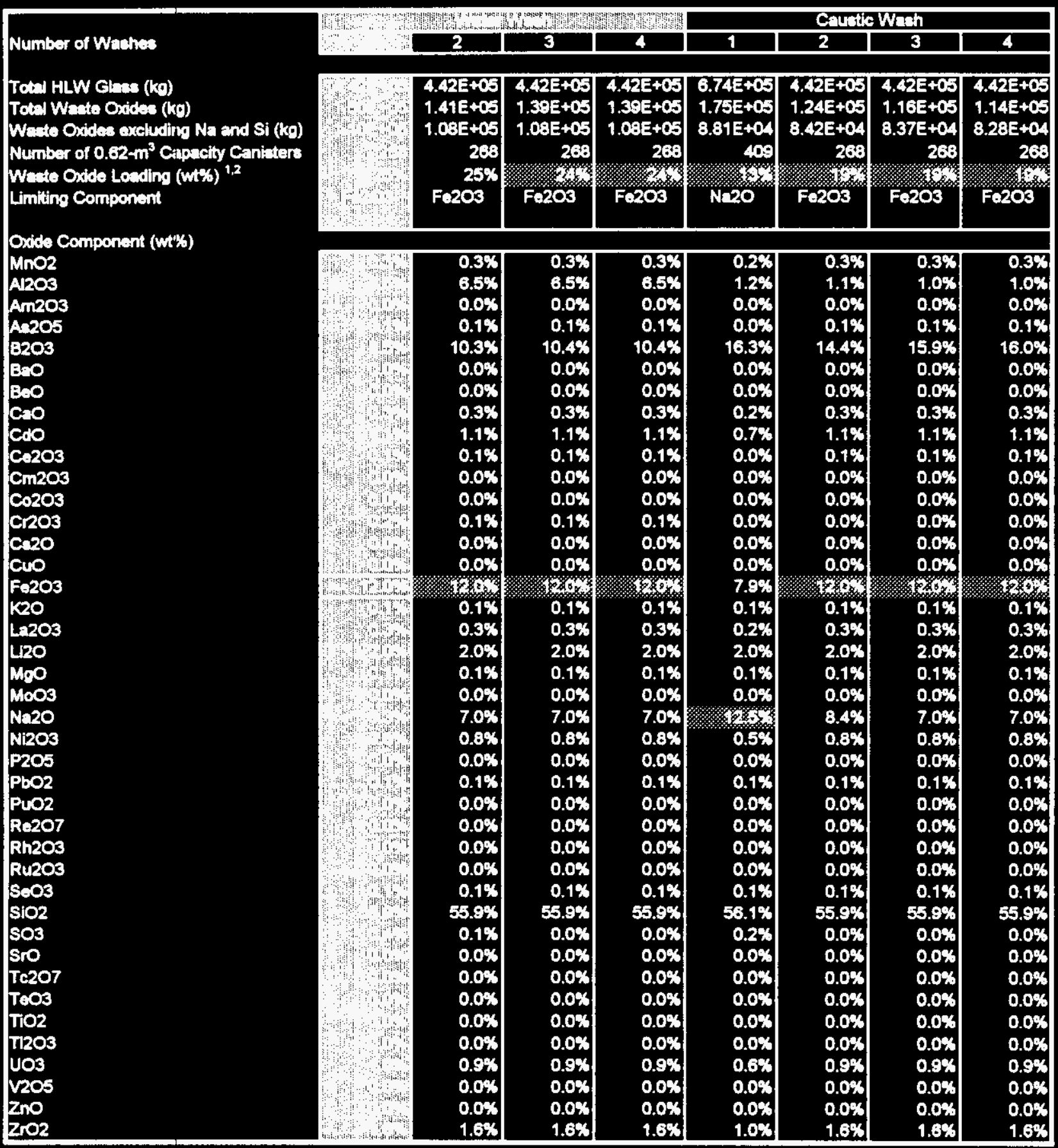

1) Note: HWVP giasi mut contein a mininum of $7 \mathrm{wH} \mathrm{B}_{2} \mathrm{O}_{3}, 2 \mathrm{wt}, \mathrm{Li}_{2} \mathrm{O}$, and 48 wtw $\mathrm{SLO}_{2}$. This linits the wate oxide

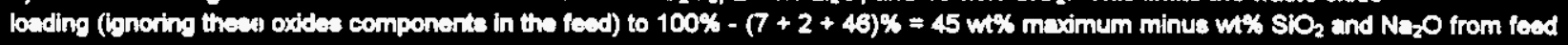
2) Waste oxide loading excludes foed Na and Si. 
WHC-SD-WM-ES-370

Revision 0

Table C-11 presents the low-temperature glass formulations assumed as bounding cases for this analysis.

Table C-11. Low-Temperature Glass Formulations for High-Level Waste. (2 sheets)

\begin{tabular}{|c|c|c|c|c|}
\hline \multirow[b]{3}{*}{ Oxide component ${ }^{\mathrm{c}}$} & \multicolumn{4}{|c|}{ Low-temperature glass formulation } \\
\hline & \multicolumn{2}{|c|}{ Flowsheet (Orme 1995)' } & \multicolumn{2}{|c|}{ CVS $\left(1150^{\circ} \mathrm{C}\right)^{b}$} \\
\hline & Lower limit & Upper limit & Lower limit & Upper limit \\
\hline \multicolumn{5}{|c|}{ Single-component constraints } \\
\hline $\mathrm{SiO}_{2}$ & 46.0 & 56.0 & 42.0 & 57.0 \\
\hline $\mathrm{B}_{2} \mathrm{O}_{3}$ & 7.0 & 17.0 & 5.0 & 20.0 \\
\hline $\mathrm{Na}_{2} \mathrm{O}+\mathrm{K}_{2} \mathrm{O}$ & 7.0 & 12.5 & 5.0 & 20.0 \\
\hline $\mathrm{Li}_{2} \mathrm{O}$ & 2.0 & 6.0 & 1.0 & 7.0 \\
\hline $\mathrm{CaO}$ & 0.0 & 7.0 & 0.0 & 10.0 \\
\hline $\mathrm{MgO}$ & 0.0 & 5.0 & 0.0 & 8.0 \\
\hline $\mathrm{Fe}_{2} \mathrm{O}_{3}$ & 4.0 & 12.0 & 2.0 & 15.0 \\
\hline $\mathrm{Al}_{2} \mathrm{O}_{3}$ & 1.0 & 11.0 & 0.0 & 15.0 \\
\hline $\mathrm{ZrO}_{2}$ & - & 10.0 & - & 13.0 \\
\hline Others & 2.5 & 8.0 & 1.0 & 10.0 \\
\hline \multicolumn{5}{|c|}{ Multiple-component constraints ${ }^{\mathrm{i}}$} \\
\hline $\begin{array}{l}\text { Viscosity: } \\
\left(\mathrm{Li}_{2} \mathrm{O}+\mathrm{Na}_{2} \mathrm{O}\right) /\left(\mathrm{SiO}_{2}+\mathrm{Al}_{2} \mathrm{O}_{3}+\mathrm{ZrO}_{2}\right)^{\circ}\end{array}$ & 0.152 & 0.342 & 0.152 & 0.342 \\
\hline \multicolumn{5}{|l|}{ Crystallinity: } \\
\hline $\mathrm{SiO}_{2} / \mathrm{Al}_{2} \mathrm{O}_{3}^{\circ}$ & 4.5 & - & 3.0 & - \\
\hline $\mathrm{MgO}+\mathrm{CaO}$ & - & 8.0 & -- & 10.0 \\
\hline $\mathrm{Al}_{2} \mathrm{O}_{3}+\mathrm{ZrO}_{2}{ }^{\mathrm{f}}$ & - & 14.0 & - & 16.0 \\
\hline $\mathrm{Al}_{2} \mathrm{O}_{3}+\mathrm{Fe}_{2} \mathrm{O}_{3}+\mathrm{ZtO}_{2}{ }^{\mathrm{f}}$ & - & 21.0 & - & 24.0 \\
\hline \multicolumn{5}{|c|}{ Solubility limits } \\
\hline $\mathrm{C}_{2} \mathrm{O}_{3}$ & - & 0.5 & - & 0.5 \\
\hline $\mathrm{F}$ & $=$ & 1.7 & - & 1.7 \\
\hline $\mathrm{P}_{2} \mathrm{O}_{5}{ }^{8, \mathrm{~L}}$ & - & $3.0^{\mathrm{h}}$ & - & $3.0^{h}$ \\
\hline $\mathrm{Rh}_{2} \mathrm{O}_{3}+\mathrm{PdO}+\mathrm{Ru}_{4} \mathrm{O}_{3}$ & - & 0.25 & $\because$ & 0.25 \\
\hline $\mathrm{SO}_{3}$ & -- & 0.5 & - & 0.5 \\
\hline
\end{tabular}


WHC-SD-WM-ES-370

Revision 0

Table C-11. Low-Temperature Glass Formulations for High-Level Waste. (2 sheets)

\begin{tabular}{|c|c|c|c|c|}
\hline \multirow[b]{3}{*}{ Oxide component } & \multicolumn{4}{|c|}{ Low-temperature glass formulation } \\
\hline & \multicolumn{2}{|c|}{ Flowsheet (Orme 1995)" } & \multicolumn{2}{|c|}{$\operatorname{CVS}\left(1150^{\circ} \mathrm{C}\right)^{\mathrm{b}}$} \\
\hline & Lower limit & Upper limit & Lower limit & Upper limit \\
\hline \multicolumn{5}{|c|}{ Redox constraints } \\
\hline Reductants (formic acid, oxalic acid, and sugar) & TBD & - & TBD & -- \\
\hline
\end{tabular}

'Based on Table 13-11 of the Hanford Waste Vitrification Plant Project Technical Data Package, Rev. 6, dated February 1994 (WHC-SD-HWV-DP-001).

'Based on Tables 4.2 and 4.3 of Property/Composition Relationships for Hanford High-Level Waste

Glasses Melting at $1150^{\circ} \mathrm{C}$, Vol. 1, dated December 1994 (PNL-10359).

$\mathrm{g}$ of oxide component per $100 \mathrm{~g}$ of nonvolatile (glass forming) oxides, halides, sulfate, and phosphate.

${ }^{d}$ All other glass components not specifically identified.

Not currently used in the flowsheets.

${ }^{5}$ The $\mathrm{Fe}_{2} \mathrm{O}_{3}, \mathrm{Al}_{2} \mathrm{O}_{3}, \mathrm{ZrO}_{2}$ and Others will not simultaneously be at their respective maximums.

${ }^{8}$ The phosphorous contributions from non-feed sources shall not exceed $0.066 \mathrm{wt} \%$ (as $\mathrm{PO}_{4}^{-3}$ ) of the total glass-forming oxides in a melter feed batch.

${ }^{b}$ The phosphorus limit used in the flowsheets (Orme 1995) is $3.0 \mathrm{wt} \% \mathrm{PO}_{4}^{-3}\left(5.2 \mathrm{wt} \%\right.$ as $\mathrm{AlPO}_{4}$ ). In the references above, the phosphorus limit is listed as $1.0 \mathrm{wt} \% \mathrm{P}_{2} \mathrm{O}_{5}$ - equivalent to $1.33 \mathrm{wt} \%$ as $\mathrm{PO}_{4}^{-3}$.

Multiple: component constraints are ignored for the CVS glass formulation (TBD). 
WHC-SD-WM-ES-370

Revision 0

This page intentionally left blank. 
WHC-SD-WM-ES-370

Revision 0

APPENDIX D

PHASE I HIGH-LEVEL WASTE INVENTORY AND GLASS COMPOSITION ESTIMATES

D-1 
WHC-SD-WM-ES-370

Revision 0

This page intentionally left blank.

D-2 
WHC-SD-WM-ES-370

Revision 0

\section{APPENDR D}

\section{PHASE I HIGH-LEVEL WASTE INVENTORY AND GLASS COMPOSITION ESTIMATES}

The purpose of this appendix to the study is to provide glass formulation estimates for representative Phase I high-level waste (HLW) at the Hanford Site. These estimates are needed for development of the Phase I HLW Pretreatment and Feed Staging Plan and to assess the need for caustic washing and for specific blending strategies to minimize the potential volume of Phase I HLW glasses. These glass composition estimates, which were provided by Pacific Northwest National Laboratory (PNNL), are based on current property models for borosilicate glass, especially the first and second order models that were developed during the composition variation study (CVS) at Hanford (Hrma 1994).

The cornposition limits of the CVS study have sometimes been used to estimate the composition of HLW glass, but some of these glasses may not have acceptable properties in the melter. The only acceptable basis for determining glass composition from CVS data is to use the empirical property models for borosilicate glass. These models can be used to estimate the most important properties of the glass based on the combined effect of all of the major components in the glass. Generally good empirical models for viscosity, electrical conductivity and Product Consistency Test (PCT) releases are available, but comparable models for liquidus temperature are not. Liquidus temperature is likely to be the property that limits waste loading for Phase I privatization feeds.

The waste compositions of interest include water washed and caustic washed wastes from tanks AZ-101, AZ-102, and C-106 and washed blends from AZ-101/AZ-102 (AZ blend), a nominal RFP blend (consisting of 80 percent AZ-101, 80 percent AZ-102, 37 percent $\mathrm{C}-106$ and 15 percent AY-102), and an all tank blend (AZ-101/AZ-102/ C106/AY-102). These waste compositions were derived from the Tank Characterization Reports for AZ-101, AZ-102 and AY-102, except for the sludge and aluminum inventories in AZ-101 (Hodgson 1995, Ryan 1995a, 1995b). Composition estimates for C-106 are based on the Data Transmittal Package for C-106 (Weiss 1988). The sludge inventory in AZ-101 was increased by 23.5 percent to make this inventory consistent with the sludge level measurements that were taken at the time of sampling in May 1989. The AZ-101 aluminum inventory was also changed so that the amount of aluminum is consistent with purchase records, flowsheet values and the supernate composition in this tank. Two separate estimates are also provided for $\mathrm{C}-106$ to bound the expected range of aluminum and iron in this waste (based on Weiss and Hara, C106A and C106B, respectively) (Weiss 1988, Hara 1990). Water and caustic washed sludge compositions were developed from core sample washing studies, analytical results for C-106 waste and from caustic washing results for tank C-103 waste (as the best available surrogate for C-106 waste) (Peterson 1989, Gray 1993a, Gray 1993b, Weiss 1988, Rapko 1995). 
Estimated glass compositions were developed for each waste (glasses that optimize waste oxide loading at $1150{ }^{\circ} \mathrm{C}$ for water and caustic washed sludges) (Vienna 1995). These glasses were especially formulated for a low-temperature joule-heated melter operating at $1150^{\circ} \mathrm{C}$. The glass properties of most importance are viscosity and electrical conductivity of the glass, liquidus temperature, and leach resistance or durability properties of the glass. The Phase I glasses were formulated for a viscosity and electrical conductivity of $5.0 \mathrm{~Pa} . \mathrm{S}$ and 40 to $60 \mathrm{ohm} / \mathrm{cm}$ at $1150^{\circ} \mathrm{C}$, respectively, a liquidus temperature of $1050{ }^{\circ} \mathrm{C}\left(100^{\circ} \mathrm{C}\right.$ below the nominal operating temperature of the melter), and boron and sodium releases, as determined by the PCT test, of less than $2.0 \mathrm{~g} / \mathrm{m}^{2}$. Liquidus temperature is especially important because this is the temperature where the melt is in equilibrium with the primary crystalline phase (indicating possible sludge forming conditions in the melter), and because liquidus temperature appears to be the limiting constraint for most of the Phase I glasses.

The estimated glass compositions for the Phase I wastes are provided in the following table. This table also provides corresponding estimates for the maximum waste oxide loading and number of glass canisters produced from each waste. Glass property estimates are indicated as well for each of the Phase I wastes, including boron and sodium PCT releases $\left(r_{b}, r_{N a}\right)$, melting temperature $\left(T_{M}\right)$, and predicted liquidus temperature $\left(T_{L}\right)$ based on the model developed by D. Kim (Hrma 1994). Results are presented for both water washed and caustic washed wastes. Of the glasses studied, 11 out of 14 appear to be limited by $\mathrm{Fe}_{2} \mathrm{O}_{3}$ (CVS linnit of $<15$ percent), while the other 3 are limited by low $\mathrm{SiO}_{2}$ and $\mathrm{B}_{2} \mathrm{O}_{3}$ (CVS limits of $>37$ percent $\mathrm{SiO}_{2}$ and $>5$ percent $\mathrm{B}_{2} \mathrm{O}_{3}$ ). Glasses with more than 15 percent $\mathrm{Fe}_{2} \mathrm{O}_{3}$ have not been studied because these glasses are likely to precipitate spinel and hematite, thus failing the applicable liquidus temperature conditions in the melter.

The canister glass predictions are especially important for these wastes. In all cases, except for C106B, glass canister estimates for water washed and caustic washed wastes are virtually the same. Based on this analysis, it appears that the caustic washing process will not provide any useful benefit for these wastes because most glasses produced from these wastes are limited by $\mathrm{Fe}_{2} \mathrm{O}_{3}$ and not by $\mathrm{Al}_{2} \mathrm{O}_{3}$. However, caustic washing may be of some benefit for C-106 waste if this waste, after more extensive sampling, is determined to have aluminum and iron compositions that matches the C106B (Hara) estimates for this waste (Hara 1990).

Laboratory scoping tests are currently underway to measure the liquidus temperatures of representative Phase I glasses. Liquidus temperature was selected for the initial screening because it is expected to be the key property limiting waste loading of Phase I waste feeds. Ten glasses were chosen for this initial evaluation, representing the minimum and maximum waste oxide loading for five wastes. The five wastes include the water washed C106A, C106B, and nominal RFP and AZ blends, and a caustic washed nominal RFP blend. The following table provides the composition and glass property estimates for these glasses.

Based on preliminary results, four of the five glasses have acceptable liquidus temperature behavior at the minimum $25 \mathrm{wt} \%$ adjusted waste oxide loading (net of waste without sodium and silica). The water washed AZ blend did not meet this criteria and must 
be reformulated by adding $\mathrm{Na}_{2} \mathrm{O}$ to suppress the precipitation of spinel. Three of the five glasses with higher waste oxide loadings failed the liquidus temperature screening, necessitating the reformulation of the water washed C106A, AZ and nominal waste glasses by reducing the waste oxide composition in these glasses. All of the reformulated glasses appear to have acceptable liquidus temperature behavior. The screening tests to date suggest that only a very limited range of waste oxide loadings above the minimum specified in the RFP may be available for these waste feed compositions due to liquidus temperature considerations.

The 10 glasses passing the initial liquidus screening are now being prepared for PCT testing. Preliminary results to date suggest the water washed C106A composition may not be acceptable because nepheline $\left(\mathrm{NaAlSiO}_{4}\right.$ ) precipitation in the Canister Centerline Cooled (CCC) sample. The precipitation of nepheline during CCC cooling is commonly associated with poor durability results from the PCT test with unacceptable releases of sodium and boron from the matrix glass. This glass property is especially important because aluminum has a significant affect on the precipitation of nepheline and aluminum can only be reduced by reducing the waste oxide loading, diluting the waste, or by using the caustic washing process to treat the waste. 


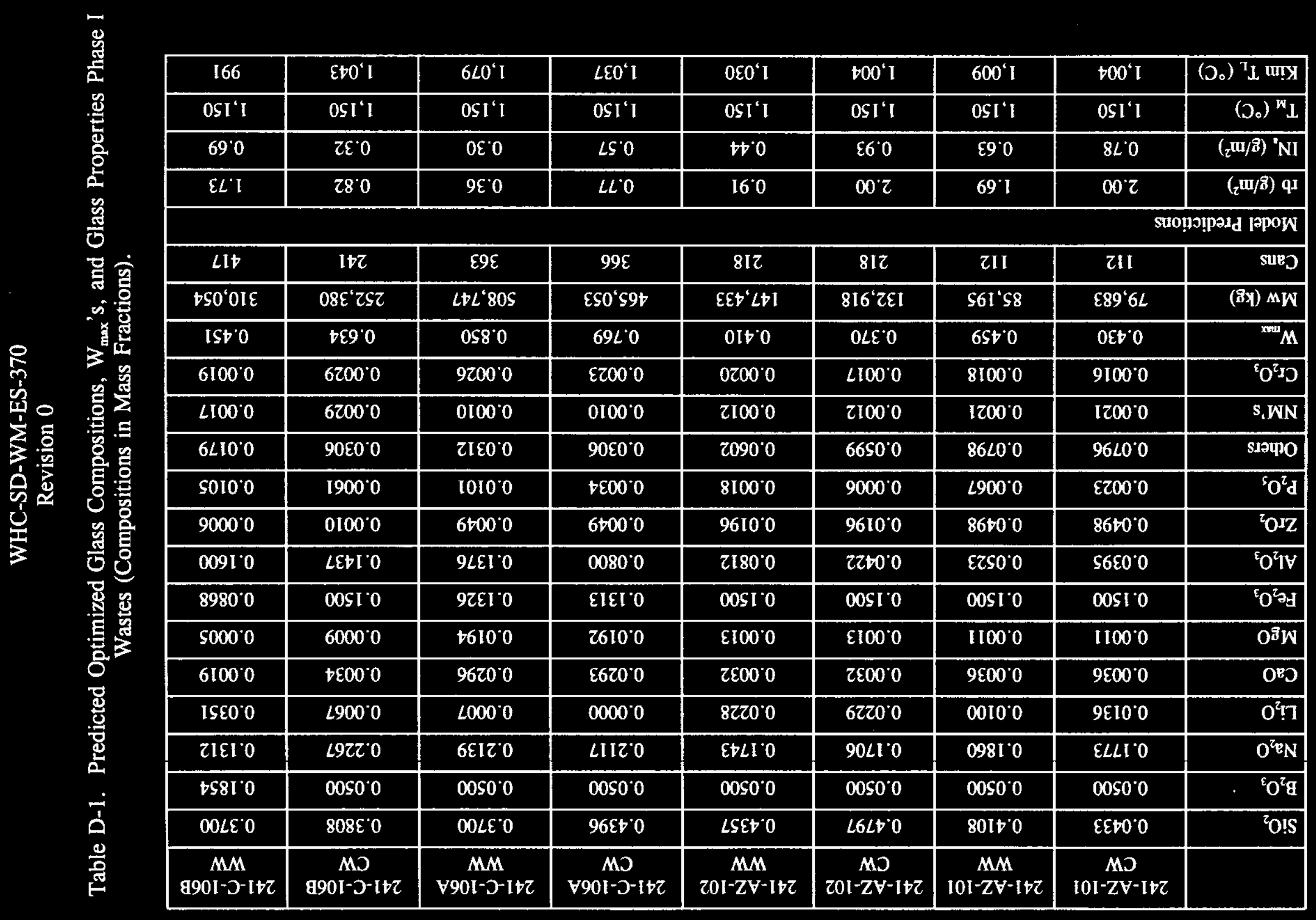


Table D-1. Predicted Optimized Glass Compositions, $\mathrm{W}_{\max }$ 's, and Glass Properties Phase I Wastes (Compositions in Mass Fractions). (Continued)

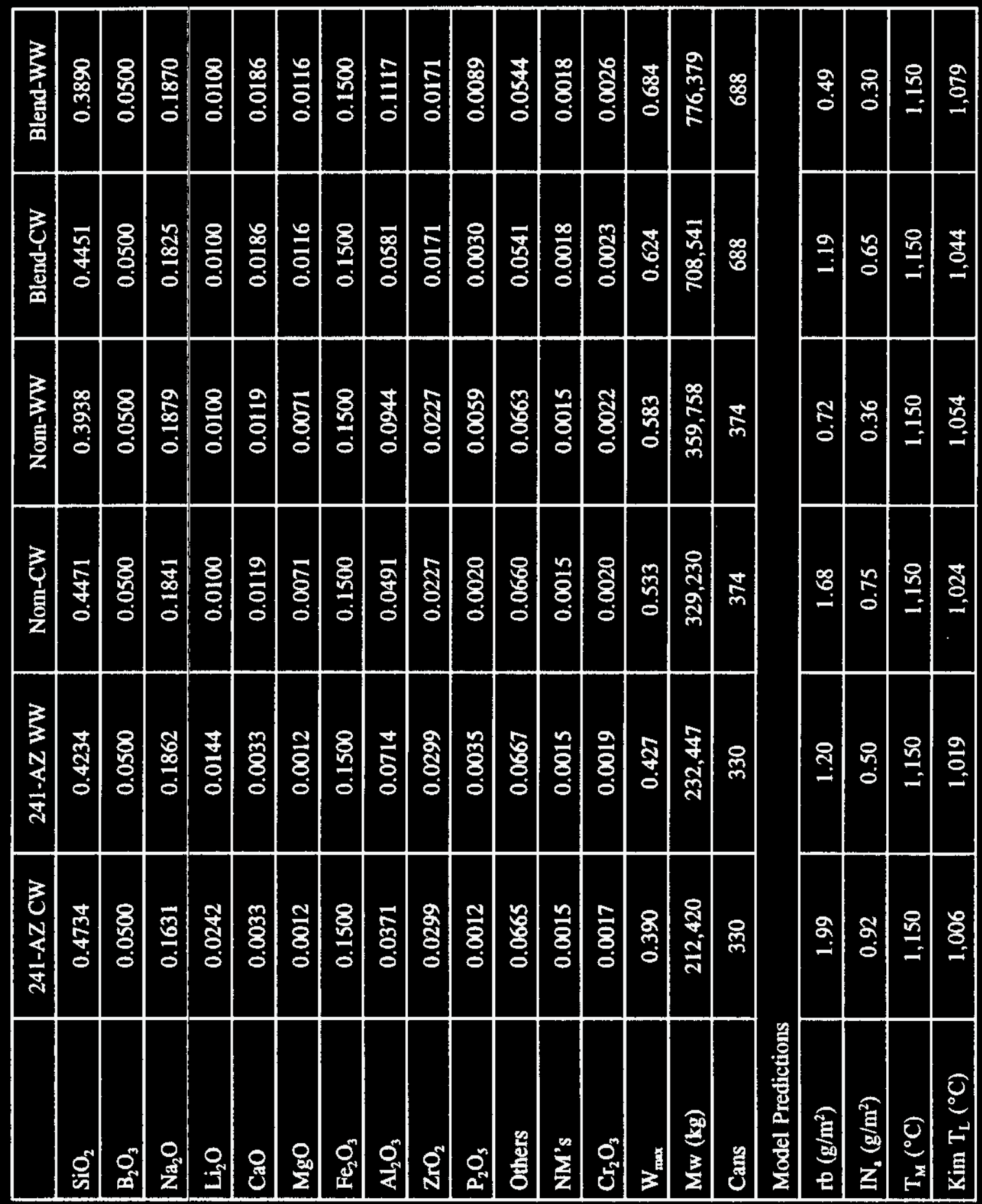




\section{Revision 0}

Table D-2. Experimental Glass Compositions.

\begin{tabular}{|c|c|c|c|c|c|c|c|c|c|c|c|c|c|c|c|c|c|c|c|c|c|c|c|c|c|}
\hline 紊 & है। & ָे & $\begin{array}{l}\stackrel{\vec{n}}{n} \\
0 \\
0\end{array}$ & $\mid$ & 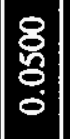 & $\begin{array}{l}\stackrel{\mathscr{o}}{\circ} \\
\stackrel{0}{0}\end{array}$ & 8 & 응 & 훙 & 总 & 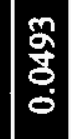 & 造 & $\frac{9}{8}$ & 兽 & & $\begin{array}{l}\infty \\
8 \\
\delta \\
0 \\
0\end{array}$ & శ్రి & 商 & 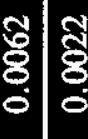 & స్ & $\stackrel{0}{=}$ & శ్రి & $\stackrel{\mathbb{N}}{-}$ & & $\frac{0}{m}$ \\
\hline $\begin{array}{l}\mathrm{E} \\
\mathrm{z}\end{array}$ & z & స్ & 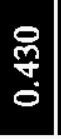 & 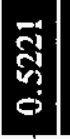 & $\mid \begin{array}{l}\infty \\
0 \\
0 \\
0 \\
0\end{array}$ & $\begin{array}{l}5 \\
\\
0\end{array}$ & ত్ర్ర & 응 & 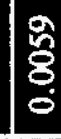 & $\mid$\begin{tabular}{l}
2 \\
\multirow{3}{3}{} \\
0 \\
0
\end{tabular} & $\frac{2}{8}$ & $\begin{array}{l}\overline{0} \\
0 \\
0\end{array}$ & $\begin{array}{l}n \\
\overline{8} \\
0 \\
0\end{array}$ & $\begin{array}{l}\text { F } \\
\text { Oे } \\
0\end{array}$ & & & $\begin{array}{l}0 \\
\overline{8} \\
0\end{array}$ & \begin{tabular}{l|l}
$\tilde{c}$ \\
$\bar{c}$ \\
0 \\
0
\end{tabular} & \begin{tabular}{l|l}
\multirow{్}{\delta}{} & 9 \\
& 8 \\
& 8 \\
\end{tabular} & $\begin{array}{l}2 \\
\\
\\
\\
\end{array}$ & $\frac{0}{2}$ & ర్రి & $\stackrel{\mathbb{A}}{-}$ & & $\frac{0}{m}$ \\
\hline 妾 & 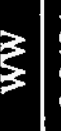 & 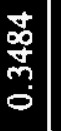 & 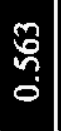 & $\mid$ & $\mid \begin{array}{l}8 \\
0 \\
0 \\
0\end{array}$ & $\frac{\bar{\sigma}}{0}$ & 8 & $\frac{9}{0}$ & 항 & $\frac{8}{0}$ & 总 & 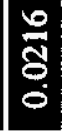 & $\begin{array}{l}n \\
\delta \\
0 \\
0\end{array}$ & $\mid \begin{array}{l}0 \\
0 \\
0 \\
0 \\
0\end{array}$ & & 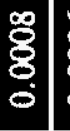 & 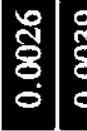 & \begin{tabular}{l|l}
$\tilde{\tilde{z}}$ \\
$\bar{\delta}$ \\
\end{tabular} & 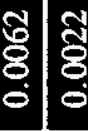 & है & $\stackrel{\varnothing}{=}$ & $\overline{\bar{s}} ;$ & $\begin{array}{l} \pm \\
0 \\
0\end{array}$ & & 号 \\
\hline 竞 & $\xi$ & đֶ. & 柔 & 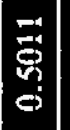 & \begin{tabular}{|l|}
$\tilde{\alpha}$ \\
0 \\
0 \\
0
\end{tabular} & $\begin{array}{l}\frac{m}{a} \\
\dot{\partial} \\
0\end{array}$ & $\begin{array}{l}8 \\
8 \\
0 \\
0\end{array}$ & 迥 & 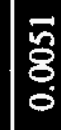 & $\mid \frac{0}{0}$ & $\mid \begin{array}{l}\overline{0} \\
8 \\
0\end{array}$ & 咢 & $\mid \begin{array}{l}0 \\
\bar{\delta} \\
0 \\
0\end{array}$ & $\mid \begin{array}{l}0 \\
\frac{8}{0} \\
0 \\
0\end{array}$ & & $\begin{array}{l}0 \\
0 \\
0 \\
0\end{array}$ & \begin{tabular}{|c|c}
$\infty$ \\
$\overline{8}$ \\
0
\end{tabular} & ఫొ & \begin{tabular}{l|l}
0 & 0 \\
8 & 8 \\
0 & 0
\end{tabular} & & $\stackrel{ஜ}{=}$ & 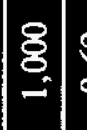 & $\begin{array}{l}\text { ర్d } \\
0 \\
\end{array}$ & & 靣 \\
\hline 等 & 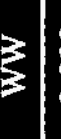 & \begin{tabular}{c|c}
\multirow{2}{*}{} \\
o. \\
0
\end{tabular} & 웅 & $\frac{\bar{d}}{\bar{d}}$ & $\begin{array}{l}8 \\
8 \\
0 \\
0 \\
0\end{array}$ & $\frac{\sqrt{0}}{0}$ & 8 & 然 & $\frac{\pi}{8}$ & $\frac{8}{8}$ & $\frac{m}{\delta}$ & 兽 & ठิి & 宽 & & 응 & 帘 & 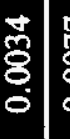 & 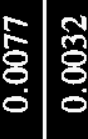 & & $\frac{0}{2}$ & $\begin{array}{l}0 \\
0\end{array}$ & $\stackrel{n}{-}$ & & ते \\
\hline $\begin{array}{l}\frac{1}{d} \\
\frac{1}{d}\end{array}$ & 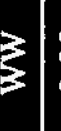 & 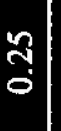 & $\stackrel{\infty}{m}$ & $\left|\begin{array}{|l}\bar{i} \\
\bar{v} \\
c \\
c\end{array}\right|$ & $\frac{9}{0}$ & $\begin{array}{l}\text { : } \\
\text { on } \\
0 \\
0\end{array}$ & $\begin{array}{l}8 \\
0 \\
0 \\
0\end{array}$ & छ్రి & 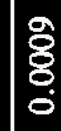 & $\mid \begin{array}{l}* \\
0 \\
0\end{array}$ & 芯 & 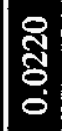 & 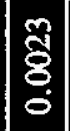 & $\mid \begin{array}{l}5 \\
\frac{9}{0} \\
0 \\
0\end{array}$ & & \begin{tabular}{l|l}
$\infty$ \\
$\delta$ \\
$\delta$ \\
0 \\
0
\end{tabular} & $\stackrel{\infty}{\stackrel{\infty}{\delta}}$ & 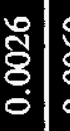 & 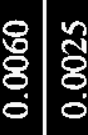 & & $\stackrel{8}{=}$ & 5 & $\begin{array}{l}x \\
0\end{array}$ & & ন্ন \\
\hline $\begin{array}{l}8 \\
\frac{8}{4} \\
\frac{1}{7} \\
\frac{1}{4}\end{array}$ & 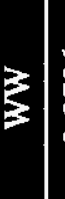 & 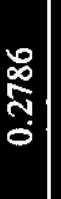 & $\overline{5}$ & $\left|\begin{array}{|c}8 \\
5 \\
5 \\
6 \\
6\end{array}\right|$ & $\stackrel{\infty}{\infty}$ & $\frac{0}{m}$ & $\begin{array}{l}\bar{n} \\
0 \\
0 \\
0\end{array}$ & శ్ర్రి & | & $\mid \begin{array}{c}\tilde{0} \\
0 \\
0\end{array}$ & $\mid \begin{array}{l}7 \\
0 \\
0 \\
0\end{array}$ & 兽 & $\mid \begin{array}{l}0 \\
0 \\
0 \\
0\end{array}$ & $\begin{array}{l}0 \\
0 \\
0\end{array}$ & & $\begin{array}{l}8 \\
\delta \\
\varnothing \\
0\end{array}$ & $\begin{array}{l}0 \\
8 \\
0\end{array}$ & 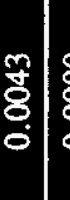 & \begin{tabular}{l|l} 
\\
\end{tabular} & & है & ๙ू & $\stackrel{\overbrace{}}{9}$ & & gे \\
\hline $\begin{array}{l}\frac{8}{0} \\
\frac{1}{3} \\
\frac{1}{3}\end{array}$ & $\xi$ & ત્ર. & 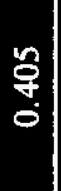 & $\begin{array}{l}\overrightarrow{6} \\
0 \\
0 \\
0\end{array}$ & $\frac{\sigma}{0}$ & $\frac{\bar{m}}{0}$ & $\begin{array}{l}0 \\
\text { ô } \\
0\end{array}$ & $\stackrel{\infty}{\delta}$ & 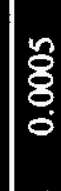 & $\overline{0}$ & $\frac{\frac{8}{9}}{0}$ & 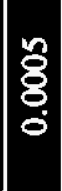 & $\mid \begin{array}{l}\text { 离 } \\
8 \\
0\end{array}$ & $\begin{array}{l}\tilde{\widehat{n}} \\
0 \\
0 \\
0\end{array}$ & & $\begin{array}{l}8 \\
\varnothing \\
0\end{array}$ & 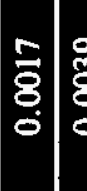 & हి & \begin{tabular}{l|l} 
\\
\\
\end{tabular} & 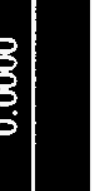 & $\stackrel{\wp}{\cong}$ & 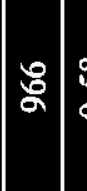 & $\begin{array}{l}0 \\
0 \\
0\end{array}$ & & 을 \\
\hline 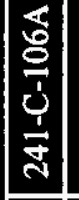 & 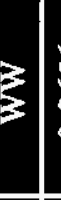 & 总 & $\begin{array}{l}\stackrel{0}{0} \\
0 \\
\circ\end{array}$ & 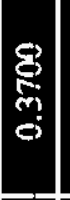 & 宮 & 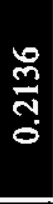 & ठ요 & $\begin{array}{l}\text { ఫั } \\
\text { క్ }\end{array}$ & $\frac{5}{\circ}$ & 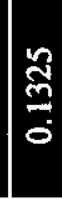 & $\frac{m}{m}$ & 竎 & 홍 & $\begin{array}{l}0 \\
\text { o. } \\
0 \\
0\end{array}$ & & $\begin{array}{l}\delta \\
\delta \\
0 \\
0\end{array}$ & $\begin{array}{l}8 \\
8 \\
0 \\
0\end{array}$ & 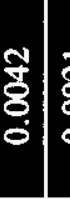 & ఫ్ర్ & 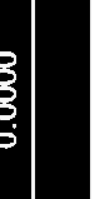 & $\begin{array}{l}ஜ \\
= \\
=\end{array}$ & $\hat{\delta}$ & $\begin{array}{l}\text { ஜ̊. } \\
\text { o. }\end{array}$ & & 율 \\
\hline $\begin{array}{l}\frac{0}{0} \\
\frac{1}{3} \\
\frac{\pi}{d}\end{array}$ & 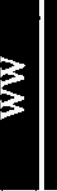 & 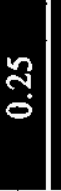 & $\begin{array}{l}\overrightarrow{0} \\
\stackrel{0}{0}\end{array}$ & 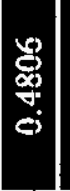 & $\begin{array}{l}\overline{0} \\
\stackrel{0}{\circ} \\
\odot\end{array}$ & $\begin{array}{l}\frac{\bar{o}}{0} \\
0 \\
0\end{array}$ & 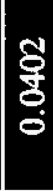 & 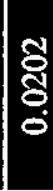 & ô & $\mid \begin{array}{l}\mathscr{\circ} \\
0 \\
0\end{array}$ & 章 & 芯 & $\begin{array}{l}\text { ठे } \\
0 \\
0\end{array}$ & 递 & 紫 & $\begin{array}{l}8 \\
\delta \\
\varnothing \\
\varnothing\end{array}$ & 8 & ఫ్రి & 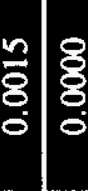 & 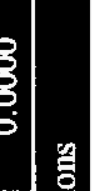 & $\frac{7}{2}$ & $\bar{\sigma}$ & ஜ̆ & & 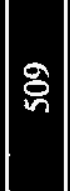 \\
\hline 景 & 总 & & & P) & 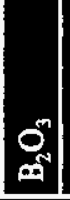 & & & & 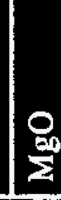 & & 足 & & $\mid \begin{array}{l}0 \\
0 \\
0\end{array}$ & 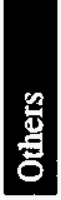 & 总 & ర్ర్రా & 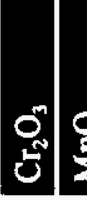 & $\stackrel{0}{g}$ & 8 & 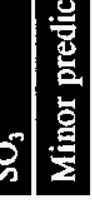 & $\left|\begin{array}{l}0 \\
0 \\
0 \\
\sum \\
i\end{array}\right|$ & $\mid \begin{array}{l}\ddot{*} \\
0 \\
0 \\
\vec{H}\end{array}$ & 高 & 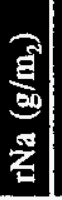 & $\mid \begin{array}{l}\frac{00}{2} \\
\frac{3}{2} \\
\sum\end{array}$ \\
\hline
\end{tabular}


WHC-SD-WM-ES-370

Revision 0

\section{REFERENCES}

Gray, W. J., M. E. Peterson, R. D. Scheele and J. M. Tingey, 1993a, Characterization of the Second Core Sample of Neutralized Current Acid Waste from Double-Shell Tank 101-AZ, Pacific Northwest Laboratory, Richland, Washington.

Gray, W. J., M. E. Peterson, R. D. Scheele and J. M. Tingey, 1993b, Characterization of First Core Sample of Neutralized Current Acid Waste from Double-Shell Tank 102-AZ, Pacific Northwest Laboratory, Richland, Washington.

Hara, F. T., 1990, SST Sample Characterization Analysis of Archive Samples 102-C, 105-C and 106 $C$, PNL-7258, Pacific Northwest Laboratory, Richland, Washington.

Hodgson, K. M., 1995, Tank Characterization Report for Double-Shell Tank 241-AZ-101, WHC-SI-WM-ER-410, Westinghouse Hanford Company, Richland, Washington.

Hrma, P. R. and G. F. Piepel, 1994, Property/Composition Relationships for Hanford Waste Vitrification Plant Glasses - Results Through CVS-II, Phase 4, PNL-10359, Vol. 1 and 2, Pacific Northwest Laboratory, Richland, Washington.

Peterson, M. E., R. D. Scheele and J. M. Tingey, 1989, Characterization of the First Core Sample of Neutralized Current Acid Waste from Double-Shell Tank 101-AZ, PNL-7758, Pacific Northwest Laboratory, Richland, Washington.

Rapko, B. M., 1995, Washing and Caustic Leaching of Hanford Tank Sludges: Results of FY 95 Studies, PNL-10712, Pacific Northwest National Laboratory, Richland, Washington.

Ryan, G. W., 1995a, Tank Characterization Report for Double-Shell Tank 241-AZ-102, WHC-SD-WM-ER-411, Westinghouse Hanford Company, Richland, Washington.

Ryan, G. W., 1995b, Tank Characterization Report for Double-Shell Tank 241-AY-102, WHC-SD-WM-ER-454, Westinghouse Hanford Company, Richland, Washington.

Vienna, J. D. and P. R. Hrma, 1995, Glass Formulation for Phase I High-Level Waste Vitrification, Pacific Northwest Laboratory, Richland, Washington.

Weiss, R. L., 1988, Data Transmittal Package for 241-C-106 Waste Tank Characterization, SD-RE-T'T-205, Westinghouse Hanford Company, Richland, Washington. 
WHC-SD-WM-ES-370

Revision 0

This page intentionally left blank.

D-10 
WHC-SD-WM-ES-370

Revision 0

\section{APPENDIX E}

A FARM COMPLEX WASTE TRANSFER SYSTEM VALVE PIT CONFIGURATIONS

E-1 
WHC-SD-WM-ES-370

Revision 0

This page intentionally left blank. 
WHC-SD-WM-ES-370

Revision 0

\section{APPENDIX E}

\section{A FARM COMPLEX WASTE TRANSFER SYSTEM VALVE PIT CONFIGURATIONS}

Table E- 1 provides a detailed listing of nozzles, transfer line connections, and destinations for transfer lines. Lines identified as being compliant are the systems that will be candidates for transferring waste to the private contractor's site.

Table E-1. A Farm Complex Waste Transfer System Valve Pit Configurations.

\begin{tabular}{|c|c|c|}
\hline Noz:zle & Line number & To tank/valve pit \\
\hline \multicolumn{3}{|c|}{ Value PIt 241-A-A } \\
\hline $\mathrm{L} !$ & SN-214 & 241-AX-A (L1) (compliant) \\
\hline L2: & SN-220 & 241-AW-A (compliant) \\
\hline Lit & SL-114 & 242-A (17) (compliant) \\
\hline L4 & Spare & \\
\hline Ls & SL-107 & A-101 (direct buried) \\
\hline L6 & Flush & \\
\hline $\mathrm{L}^{7}$ & Spare & \\
\hline L\& & Flush & \\
\hline L9 & SL-101 & 241-AX-A (L3) (compliant) \\
\hline L10 & Spare & \\
\hline L11 & LIQW-702 & 204-AR Loadout \\
\hline $\mathrm{L} 12$ & 4004 & PUREX \\
\hline L13 & Spare & \\
\hline L14 & SN-207 & A-101 (compliant) \\
\hline L15 & Spare & \\
\hline L16 & SN-215 & 244-A (P9) (compliant) \\
\hline L17 & Flush & 241-A-B-(R17) \\
\hline L18 & SL-014 & 241-A-B (R18) \\
\hline L19 & SN-204 & 241-A-B (R19) \\
\hline \multicolumn{3}{|c|}{ Valve pit 241-A-B } \\
\hline R1. & SN-213 Turns into SN-200 & 241-AX-B (R1) (compliant) \\
\hline RI & SN-219 & 241-AW-B (R2) (compliant) \\
\hline $\mathbf{R} \mathbf{i}$ & SL-113 & 242-A (16) (compliant) \\
\hline $\mathbf{R} 4$ & Spare & \\
\hline $\mathbf{R}$ & SL-10S & A-103 (compliant) \\
\hline $\mathbf{R} 6$ & Spare & \\
\hline$\overline{\mathrm{R}} 7$ & SL-102 & A-106 (compliant) \\
\hline R8 & Spare & \\
\hline R') & SL-100 & 241-AX-B (R3) (compliant) \\
\hline
\end{tabular}


WHC-SD-WM-ES-370

Revision 0

Table E-1. A Farm Complex Waste Transfer System Valve Pit Configurations.

\begin{tabular}{|c|c|c|}
\hline Nozzle & Line number & To tank/valve pit \\
\hline R10 & SL-106 & A-102 (compliant) \\
\hline R11 & SN-202 & A-106 (compliant) \\
\hline $\mathbf{R} 12$ & 4001/T029 & PUREX \\
\hline $\mathbf{R} 13$ & Spare & \\
\hline$\overline{\mathrm{R}} 14$ & SN-205 & A-103 (compliant) \\
\hline $\mathrm{R} 15$ & SN-650 & AP-102 (compliant) \\
\hline R16 & SN-216 & 244-A (P9) (compliant) \\
\hline R17 & Flush & \\
\hline$\overline{\mathbf{R} 18}$ & SL-104 & 241-A-A (L18) (compliant) \\
\hline$\overline{\mathbf{R}} \mathbf{1 9}$ & SN-204 & 241-A-A (L19 (compliant)) \\
\hline \multicolumn{3}{|c|}{ Valve Pit 241-AN-A } \\
\hline $\mathrm{L} 1$ & SN-267 & AN-107 (compliant) \\
\hline $\mathrm{L} 2 \mathrm{2}$ & Spare & \\
\hline $\mathrm{L}_{3}$ & SL-167 & AN-107 (compliant) \\
\hline $\mathrm{L}_{4}$ & Spare & \\
\hline L5 & SL-164 & AN-104 (compliant) \\
\hline L6 & Spare & \\
\hline L7 & $\overline{S L-165}$ & AN-105 (compliant) \\
\hline L8 & Spare & \\
\hline L9 & SL-166 & AN-106 (compliant) \\
\hline$\overline{\mathrm{L} 10}$ & Spare & \\
\hline$\overline{\mathrm{L}} 11$ & Spare & \\
\hline L12 & Spare & \\
\hline L13 & Spare & \\
\hline L14 & SN-266 & AN-106 (compliant) \\
\hline$\overline{L 15}$ & SN-264 & AN-104 (compliant) \\
\hline L16 & SN-265 & AN-105 (compliant) \\
\hline L1.7 & Spare & \\
\hline L18 & Fush & 241-AN-B (R18) \\
\hline $\mathrm{L1} 9$ & Flush & $241-A N-B$ (R19) \\
\hline \multicolumn{3}{|c|}{ Valve Pit 241-AN-B } \\
\hline $\mathbf{R} 1$ & Spare & \\
\hline$\overline{\mathbf{R} 2}$ & SN-260 & AZ-102 (compliant) \\
\hline$\overline{\mathrm{R} 3}$ & SL-160 & AZ-102 (compliant) \\
\hline R4 & Spare & \\
\hline$\overline{\mathbf{R} 5}$ & $\begin{array}{ll}\text { SL-161 } \\
\end{array}$ & AN-101 (compliant) \\
\hline R6 & Spare & \\
\hline $\mathbf{R} 7$ & SL-162 & AN-102 (compliant) \\
\hline$\overline{R 8}$ & Spare & \\
\hline$\overline{\mathrm{R} 9}$ & SL-163 & AN-103 (compliant) \\
\hline
\end{tabular}


WHC-SD-WM-ES-370

\section{Revision 0}

Table E- - . A Farm Complex Waste Transfer System Valve Pit Configurations.

\begin{tabular}{|c|c|c|}
\hline Nozzle & Line number & To tank/valve pit \\
\hline R10 & Spare & \\
\hline R11 & Spare & \\
\hline R12 & Spare & \\
\hline R13 & Spare & \\
\hline R14 & SN-263 & AN-103 (compliant) \\
\hline R15 & SN-261 & AN-101 (compliant) \\
\hline R16 & SN-262 & AN-102 (compliant) \\
\hline R17 & Spare & \\
\hline R18 & Fush & 241-AN-A (L18) \\
\hline R19 & Flush & 241-AN-A L19) \\
\hline \multicolumn{3}{|c|}{ Varve Rit 241-AW-A } \\
\hline Li & SN-267 & AW-102 (compliant) \\
\hline $\mathrm{L} 2$ & SN-220 & 241-A-A (compliant) \\
\hline $\mathrm{L3}$ & SL-168 & 242-A (compliant) \\
\hline L4 & SL-510 & 241-AP (compliant) \\
\hline$\overline{\mathrm{L}} 5$ & SL-161 & AW-101 (compliant) \\
\hline L6 & Spare & \\
\hline L7 & SL-163 & AW-103 (compliant) \\
\hline $\mathrm{LB}$ & Spare & \\
\hline L9 & SL-165 & AW-105 (compliant) \\
\hline L10 & Spare & \\
\hline L11 & Spare & \\
\hline $\mathrm{L} 12$ & $V-021$ & 241-A-151 \\
\hline L13 & Spare & \\
\hline L14 & SN-263 & AW-103 (compliant) \\
\hline L15 & SN-265 & AW-105 (compliant) \\
\hline L16 & SN-261 & AW-101 (compliant) \\
\hline L17 & Flush & 241-AW -B (R17) \\
\hline L18 & SL-169 & 241-AW-B (R18) \\
\hline L19 & SN-271 & 241-AW-B-(19) \\
\hline \multicolumn{3}{|c|}{ Valve Pit 241-AW B } \\
\hline $\mathbf{R} 1$ & SL-268 & AW-102 (compliant) \\
\hline $\mathbf{R} \mathbf{2}$ & SN-219 & 241-A-B (compliant) \\
\hline $\mathbf{R 3}$ & SL-167 & 242-A (compliant) \\
\hline $\mathbf{R 4}$ & SL-509 & 241-AP (compliant) \\
\hline $\mathbf{R 5}$ & SL-162 & $\mathrm{AW}-102$ \\
\hline R6 & Spare & \\
\hline R7 & SL-164 & AW-104 (compliant) \\
\hline$\overline{\mathbf{R} 8}$ & Spare & \\
\hline R9 & SL-166 & AW-106 (compliant) \\
\hline
\end{tabular}


WHC-SD-WM-ES-370

Revision 0

Table E-1. A Farm Complex Waste Transfer System Valve Pit Configurations.

\begin{tabular}{|c|c|c|}
\hline Nozxale & Line number & To tank/valve pit \\
\hline $\mathrm{R} 10$ & Spare & \\
\hline R11 & $\mathrm{V}-023$ & $241-A-151$ \\
\hline$\overline{\mathbf{R} 12}$ & V-022 & $241-A-151$ \\
\hline $\mathbf{R} 13$ & Spare & \\
\hline$\overline{R 14}$ & SN-264 & AW-104 (compliant) \\
\hline$\overline{\mathrm{R} 15}$ & SN-262 & AW-102 (compliant) \\
\hline$\overline{\mathrm{R} 16}$ & SN-266 & AW-106 (compliant) \\
\hline$\overline{\mathrm{R} 17}$ & Flush & 241-AW-A (L17) \\
\hline R18 & SL-169 & 241-AW-A (R18) \\
\hline R19 & SN-271 & 241-AW-A (L19) \\
\hline$\overline{\mathbf{R} 20}$ & SN-274 & AW-104 (compliant) \\
\hline \multicolumn{3}{|c|}{ Valve Pit 241-AX-A } \\
\hline $\mathrm{Lt}$ & SN-201 & 241-A-A (L1) (compliant) \\
\hline $\mathrm{L} 2$ & Spare & \\
\hline$\overline{\mathrm{L} 3}$ & SL-101 & 241-A-A (compliant) \\
\hline $\mathrm{L} 4$ & Spare & \\
\hline L.5 & SL-500 & AZ-102 (DIRECT BURIED) \\
\hline L6 & Spare & \\
\hline $\mathrm{L} 7$ & Spare & \\
\hline $\mathrm{L} 3$ & Spare & \\
\hline L9 & SL-108 & AX-101 (compliant) \\
\hline L10 & Spare & \\
\hline L11 & Spare & \\
\hline L12 & Spare & \\
\hline L13 & Spare & \\
\hline$\overline{\mathrm{L} 14}$ & SN-211 & AX-103 (compliant) \\
\hline $\mathrm{L} 15$ & SN-208 & AX-101 (compliant) \\
\hline$\overline{\mathrm{L}} \mathbf{6}$ & SN-600 & AZ-102 (compliant) \\
\hline L17 & Flush & 241-AX-B (R17) \\
\hline L18 & SL-110 & 241-AX-B (R18) \\
\hline L19 & SN210 & 241-AX-B (R19) \\
\hline \multicolumn{3}{|c|}{ Valve Pit 241-AXX-B } \\
\hline$\overline{R I}$ & SL-100 & 241-A-B (R9) (compliant) \\
\hline $\mathrm{R}^{2}$ & Spare & \\
\hline $\mathrm{R}^{3}$ & SN-200 Turns into 213 & 241-A-B (R1) (compliant) \\
\hline $\mathbf{R}_{4}$ & Spare & \\
\hline$\overline{\mathbf{R}} 5$ & Spare & \\
\hline R6 & Spare & $\cdot$ \\
\hline$\overline{\mathrm{R}} \mathbf{7}$ & SL-109 & AX-102 (compliant) \\
\hline $\bar{R} 3$ & Spare & \\
\hline
\end{tabular}


WHC-SD-WM-ES-370

Revision 0

Table E- $\mathrm{l}$. A Farm Complex Waste Transfer System Valve Pit Configurations.

\begin{tabular}{|c|c|l|}
\hline Nozzle & Line number & \multicolumn{1}{|c|}{ To tank/valve pit } \\
\hline R9 & SL-112 & AX-104 (compliant) \\
\hline R10 & Spare & \\
\hline R11 & SN-247 & AN-101 (compliant) \\
\hline R12 & Spare & \\
\hline R13 & Spare & \\
\hline R15 & SN-209 & AX-102 (compliant) \\
\hline R16 & SN-212 & AX-104 (compliant) \\
\hline R17 & SL-502 & AY-102 (compliant) \\
\hline R18 & Flush & 241-AX-A (L17) \\
\hline R19 & SL-110 & 241-AX-A (L18) \\
\hline & SN-210 & 241-AX-A (L19) \\
\hline
\end{tabular}


WHC-SD-WM-ES-370

Revision 0

This page intentionally left blank.

E-8 
DISTRIBUTION SHEET

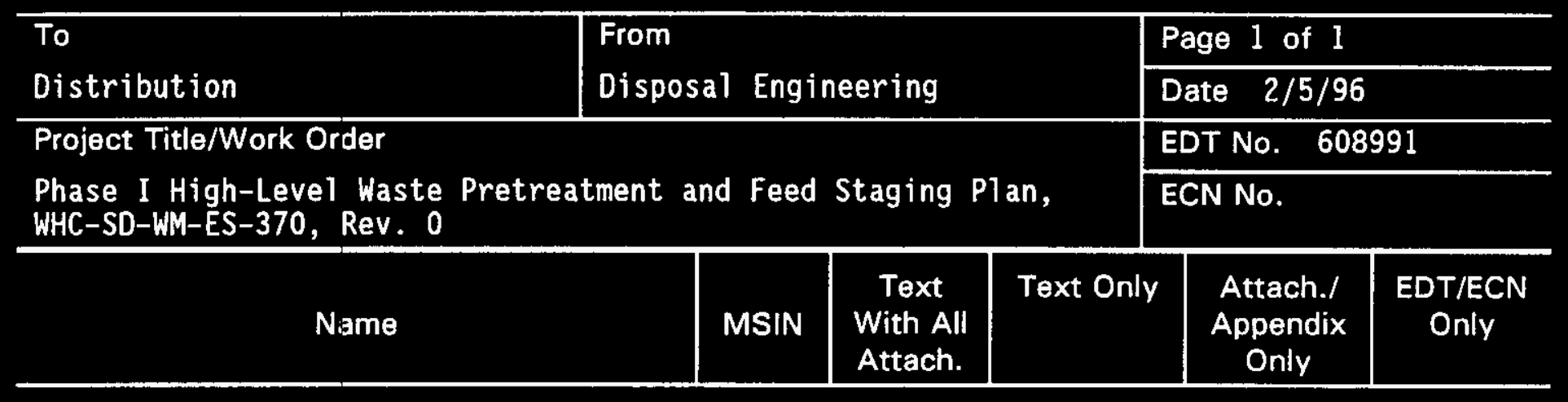

\section{Central Files}

Publ ic Reading Room

J. N. Appel

S. K. Baker

D. E. Ball

K. D. Boomer

P. J. Certa

R. D. Claghorn

R. P. Colburn

R. A. Dodd

J. L. Foster

J. D. Galbraith

J. S. Garfield

K. A. Gasper

J. E. Geary

R. L. Gibby

C. E. Grenard

J. 0. Honeyman

M. E. Johnson

R. A. Kirkbride

E. J. Kosiancic

S. L. Lambert

A. F. Manue1 (10)

G. A. Meyer

R. M. Orme

D. L. Penwe11

R. W. Powe11

W. J. Powe11

D. P. Reber

I. E. Reep

P. S. Schaus

L. W. Shelton

J. P. Sloughter

G. E. Stegen

J. E. Truax

D. J. Washenfelder

R. A. Watrous

C. M. Winkler

R. S. Wittman

\begin{tabular}{|c|}
\hline 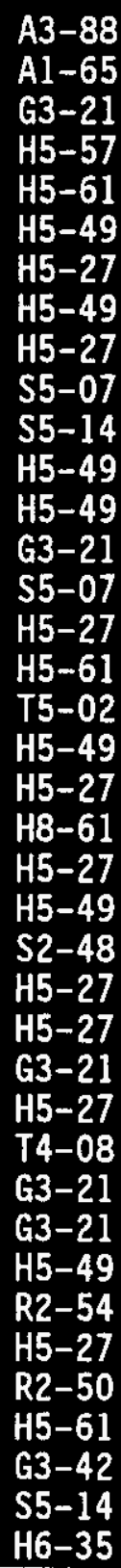 \\
\hline
\end{tabular}

